This document was prepared in conjunction with work accomplished under Contract No. DE-AC09-96SR18500 with the U. S. Department of Energy.

\title{
DISCLAIMER
}

This report was prepared as an account of work sponsored by an agency of the United States Government. Neither the United States Government nor any agency thereof, nor any of their employees, makes any warranty, express or implied, or assumes any legal liability or responsibility for the accuracy, completeness, or usefulness of any information, apparatus, product or process disclosed, or represents that its use would not infringe privately owned rights. Reference herein to any specific commercial product, process or service by trade name, trademark, manufacturer, or otherwise does not necessarily constitute or imply its endorsement, recommendation, or favoring by the United States Government or any agency thereof. The views and opinions of authors expressed herein do not necessarily state or reflect those of the United States Government or any agency thereof.

This report has been reproduced directly from the best available copy.

Available for sale to the public, in paper, from: U.S. Department of Commerce, National Technical Information Service, 5285 Port Royal Road, Springfield, VA 22161, phone: (800) 553-6847, fax: (703) 605-6900

email: orders@ntis.fedworld.gov

online ordering: http://www.ntis.gov/help/index.asp

Available electronically at http://www.osti.gov/bridge

Available for a processing fee to U.S. Department of Energy and its contractors, in paper, from: U.S. Department of Energy, Office of Scientific and Technical Information, P.O. Box 62, Oak Ridge, TN 37831-0062,

phone: (865)576-8401,

fax: (865)576-5728

email: $\underline{\text { reports@ adonis.osti.gov }}$ 


\section{IMPACT OF URANIUM LEVELS ON SLUDGE BATCH 2 SIMULANT PROCESSING}

C. J. Bannochie

D. C. Koopman

D. T. Herman

May 2004

Immobilization Technology Section

Savannah River National Laboratory Aiken, SC 29808 


\section{IMPACT OF URANIUM LEVELS ON SLUDGE BATCH 2 SIMULANT PROCESSING}

C. J. Bannochie

D. C. Koopman

D. T. Herman

May 2004 
This page was intentionally left blank 


\section{EXECUTIVE SUMMARY}

This study was conducted to address in part whether uranium contributes significantly to processing issues in the Defense Waste Processing Facility. The processing observations for Sludge Batch 2 (SB2) included the ability to transfer process slurries and feed the melter, difficulty maintaining heat transfer in the Slurry Mix Evaporator, and degradation of the operation of the melter. The Savannah River National Laboratory (SRNL) conducted small-scale tests designed to determine the effect of different levels of uranium on sludge processing at the same redox and stoichiometric factor, 0.20 and $130 \%$ respectively. Samples used a series of uranium levels, co-precipitated during sludge makeup, in a simulant of SB2. The samples with the different uranium contents were characterized and compared with each other before and after a simulated SRAT cycle process.

The following observations and conclusions were drawn from this study.

- Co-precipitation of $U$ during simulant sludge makeup results in the formation of Clarkeite, $\mathrm{Na}\left(\left(\mathrm{UO}_{2}\right) \mathrm{O}(\mathrm{OH})\right)$, a hydrated uranate containing $\mathrm{U}(\mathrm{VI})$, as the final uranium species. This same species has been identified in actual tank waste for SB2.

- There is no increase in calculated acid demand at room temperature as a result of increasing levels of $U$ in SRAT feed. Whether or not there is an impact on acid demand at elevated temperature or in the presence of mixed acids has not been addressed.

- Essentially no soluble U was found in the SRAT products with $\mathrm{pH}$ values above $\mathrm{pH}$ 6. This is consistent with observations from SRNL Shielded Cells SRAT cycles with SB2/3 blended waste $^{17}$ and SB3 waste ${ }^{18}$ which did see soluble U in the SRAT products but which had final pH's below 6. Since DWPF operated SB2 processing at approximately $\mathrm{pH} 5.5$, they should have seen more soluble $U$ and potentially thinner SRAT products.

- Different U species can be produced in the SRAT product suggesting the potential for some $\mathrm{U}$ redox activity. The primary species, $\mathrm{U}_{2} \mathrm{O}_{7}{ }^{2-}$ contained fully oxidized $\mathrm{U}(\mathrm{VI})$, while one product contained the mixed $\mathrm{U}$ oxidation state species $\mathrm{U}_{3} \mathrm{O}_{9}{ }^{2-}$. The impact of redox target on the SRAT product $\mathrm{U}$ species could not be addressed since only a single redox target was studied.

- XRD data suggests there was some dissolution and re-precipitation of $U$ as a result of SRAT processing since the SRAT product U-containing species were fine and not fully crystalline.

- SRAT vessel contents entrain gas and the volume increases during processing when the temperature is raised from 93 to $100{ }^{\circ} \mathrm{C}$, and the degree of expansion is greatest at the highest levels of $U$ (Batches 11.25 and 15).

- All six sludges and seven SRAT products were thixotropic slurries, i.e. the apparent viscosity decreased with time under shear on a time scale of ten minutes. This produced down ramp flow curves that were always below the up ramp flow curves.

- The six sludges and seven SRAT products were generally pseudo-plastic slurries, i.e. the apparent viscosity decreased with increasing shear rate. There were some transient phenomena early in some of the up ramp flow curves during which this was not true. 
- The six sludges and seven SRAT products were relatively thin and free-flowing slurries that when shaken vigorously did not retain any significant quantity of air bubbles.

- Rheological properties of the six new simulants were effectively independent of the time since preparation over a time scale of one to six weeks.

- The six new simulants had rheological properties that were bounded by those of the two Batch 7.5 preparations. This indicates that the impact of co-precipitated $U$ on rheology was no more significant than other variations in properties that occur during simulant preparation.

- SRAT product samples showed more anomalous rheological behavior than the starting sludges. This was seen in the occurrence of more transient phenomena in the up ramp flow curves. There was also a greater spread in the rheological results for the seven SRAT products than for the six starting sludges. This indicated that SRAT processing had a variable impact on rheology.

- Both the SRAT product yield stress and consistency were found to increase with an increase in uranium concentration in a statistically significant manner.

- Transient phenomena (humps) in the up flow curves never re-occurred when a sample in the rheometer was run through a second up flow curve.

- The impact of SRAT processing on rheology was most apparent in the results for the Batch 11.25 and 15 slurries. These slurries thickened significantly during SRAT processing. SRAT products have generally been thinner than the starting sludges in previous work.

There does not appear to be a straightforward relationship between the level of uranium in the feed, at least to the degree we were able to isolate this contribution from other factors such as particle size, and the processing behavior of the sludge. There are still uncertainties related to uranium and the following recommendations may help address these issues.

- Evaluation of the impact of lower $\mathrm{pH}$ during the SRAT cycle on the uranium solubility in the SRAT product may help determine if a significant dissolution of uranium has an impact on the rheological properties of the material. This may help us gain a better understanding of the relationship between rheological behavior and plant operational issues.

- Based upon the uranium species produced in the SRAT product $\left(\mathrm{U}_{2} \mathrm{O}_{7}{ }^{2-}\right.$ and $\left.\mathrm{U}_{3} \mathrm{O}_{9}{ }^{2-}\right)$, it may be useful for melter operations to understand how the redox target (ratio of nitric acid to formic acid) impacts the uranium species formed during SRAT processing. A series of SRAT tests varying the acid ratios may address this issue.

- Evaluate the impact of particle size variations on the starting sludge rheology as well as the resulting SRAT product.

- Begin to characterize the tank waste for particle size distribution to develop an understanding of the impact of this parameter on processing behavior and assess the variability of this parameter in various samples received for qualification and study. Previous methods involving extremely high dilutions into unmatched matrices, i.e. water, for 
Microtrac analysis may alter the particle size of the sludge solids. Installation of a Lasentek instrument in the SRNL Shielded Cells would address this shortcoming.

- Characterize more actual tank waste solids and SRAT product solids produced from actual tank waste by XRD to develop a better understanding of the species present and formed as a result of processing. This information can then be related back to processing issues as they arise in the plant to help explain what may be causing any given issue.

- The scale of sludge makeup should be larger than the 1L scale used in this study. Samples taken for analyses prior to completion of each slurry represent too large a fraction of the total material and results in unnecessary variability.

- The scale of SRAT cycle simulations should be larger than $300 \mathrm{~g}$. At this level noble metal additions are miniscule and acid addition rates are very low leading to considerable variability and potential error. 


\section{TABLE OF CONTENTS}

EXECUTIVE SUMMARY iii

LIST OF FIGURES vii

LIST OF TABLES $\quad$ xi

LIST OF TABLES $\quad$ xi

LIST OF ACRONYMS xii

1.0 INTRODUCTION AND BACKGROUND 1

2.0 Depleted Uranium Simulants 3

2.1 Approach 3

2.1.1 Simulant Preparation 3

2.1.2 Rheology 5

2.2 Sludge Preparation Results 6

2.2.1 Chemical Characterization $\quad 6$

$\begin{array}{lr}\text { 2.2.2 Physical Characterization } & 13\end{array}$

$\begin{array}{ll}\text { 2.2.3 Rheological Properties of SRAT Feeds } & 14\end{array}$

3.0 SRAT Cycle $\quad 21$

3.1 Approach 21

$\begin{array}{ll}3.1 .1 \text { Equipment Set-Up } & 21\end{array}$

3.1.2 Acid Calculations for the SRAT Cycles 22

$\begin{array}{ll}\text { 3.1.3 Description of SRAT Cycles } & 24\end{array}$

3.2 Results $\quad 25$

3.2.1 Product Characterization 25

3.2.2 Nitrite and Formate Destruction 26

3.2.3 Elemental Composition of SRAT Products 27

3.2.4 X-ray Diffraction and Particle Size Analyses of Solids and Entrainment $\begin{array}{ll}\text { Observations } & 31\end{array}$

3.2.5 Product Rheological Results $\quad 36$

4.0 Discussion 41

4.1 SRAT Feeds and Products 41

4.2 Rheology 44

5.0 Conclusions $\quad 49$

5.1 SRAT Feeds and Products 49

5.2 Rheology 49

6.0 RECOMMENDATIONS/PATH FORWARD 51

7.0 REFERENCES

8.0 ACKNOWLEDGEMENTS

APPENDIX A. SAMPLE SIMULANT MAKEUP PROCEDURE 57

APPENDIX B. SIMULANT RECIPES

APPENDIX C. PARTICLE SIZE MEASUREMENTS 69

APPENDIX D. SRAT FEED RHEOGRAMS 95

APPENDIX E. SRAT FEED REGRESSION ANALYSES 103

APPENDIX F. SRAT PRODUCT RHEOGRAMS 119

APPENDIX G. SRAT PRODUCT REGRESSION ANALYSES 125

Distribution: $\quad 133$ 


\section{LIST OF FIGURES}

Figure 2-1. XRD Spectra of the Batch 0 SB2 Simulant 9

Figure 2-2. XRD Spectra of the Batch 3.75 Uranium SB2 Simulant 10

Figure 2-3. XRD Spectra of the Batch 7.5i Uranium SB2 Simulant 10

Figure 2-4. XRD Spectra of the Batch 7.5ii Uranium SB2 Simulant 11

Figure 2-5. XRD Spectra of the Batch 11.25 Uranium SB2 Simulant 11

Figure 2-6. XRD Spectra of the Batch 15 Uranium SB2 Simulant 12

Figure 2-7. Comparison of the Rheology of CETL and SRNL SB2 Simulants without Uranium

Figure 2-8. Typical Up Ramp Flow Curves for the Starting Sludges 17

Figure 2-9. Typical Down Ramp Flow Curves for the Starting Sludges 17

Figure 2-10. Variation of Sludge Yield Stress - Up Ramp Basis 19

Figure 2-11. Transient Nature of Up Ramp Flow Curve Hump for Batch 15 Sludge 20

Figure 3-1. Photograph of the 1-L SRAT vessel similar to that used in this study. 21

Figure 3-2. Impact of Acid Stoichiometry on $\mathrm{pH}$ observed during the SB2 Processing Issues Study 23

Figure 3-3. Percent Soluble Metal Ion Concentration vs. SRAT Product pH 28

Figure 3-4. XRD Spectra of the Batch 0 SB2 SRAT Product 32

Figure 3-5. XRD Spectra of the Batch 3.75 Uranium SB2 SRAT Product, Run 1

Figure 3-6. XRD Spectra of the Batch 3.75 Uranium SB2 SRAT Product, Run 2

Figure 3-7. XRD Spectra of the Batch 7.5i Uranium SB2 SRAT Product 34

Figure 3-8. XRD Spectra of the Batch 7.5ii Uranium SB2 SRAT Product 34

Figure 3-9. XRD Spectra of the Batch 11.25 Uranium SB2 SRAT Product 35

Figure 3-10. XRD Spectra of the Batch 15 Uranium SB2 SRAT Product 35

Figure 3-11. Typical Up Ramp Flow Curves of the SRAT Products 37

Figure 3-12. Typical Down Ramp Flow Curves of SRAT Products 37

Figure 3-13. SRAT Product Yield Stress versus Nominal Uranium Level (Up Curve Basis) 38

Figure 3-14. SRAT Product Consistency versus Nominal Uranium Level (Up Curve Basis) 39

Figure 3-15. Re-Ramping the Batch 7.5ii SRAT Products 40

Figure 4-1. XRD Spectra of the CETL SB2 Simulant without Uranium Used in the First Impacts of U on SB2 Processing Study

Figure 4-2. XRD Spectra of the CETL SB2 Simulant with Nominally $7.5 \mathrm{wt} \%$ Uranium

Figure 4-3. XRD Spectra of the CETL SB2 Simulant with Nominally $7.5 \mathrm{wt} \%$ Uranium

Following SRAT Processing 43

Figure 4-4. Impact of SRAT Processing, Batch 0, Up Ramp Flow Curves 45

Figure 4-5. Impact of SRAT Processing, Batch 3.75, Run 1, Up Ramp Flow Curves 45

Figure 4-6. Impact of SRAT Processing, Batch 3.75, Run 2, Up Ramp Flow Curves 46

Figure 4-7. Impact of SRAT Processing, Batch 7.5i, Up Ramp Flow Curves 46

Figure 4-8. Impact of SRAT Processing, Batch 7.5ii, Up Ramp Flow Curves 47

Figure 4-9. Impact of SRAT Processing, Batch 11.25, Up Ramp Flow Curves 47

Figure 4-10. Impact of SRAT Processing, Batch 15, Up Ramp Flow Curves 48

Figure C- 1. Particle size number distribution for SB2 simulant without uranium 70

Figure C- 2. Particle size number distribution for SB2 simulant without uranium following SRAT cycle processing 
Figure C- 3. Particle size volume distribution for SB2 simulant without uranium

Figure C- 4. Particle size volume distribution for SB2 simulant without uranium following SRAT cycle processing

Figure C- 5. Particle size number distribution for SB2 simulant with $3.75 \mathrm{wt} \%$ uranium

Figure C- 6. Particle size number distribution for SB2 simulant with $3.75 \mathrm{wt} \%$ uranium following SRAT cycle processing

Figure C- 7. Particle size volume distribution for SB2 simulant with 3.75 wt $\%$ uranium

Figure C- 8. Particle size volume distribution for SB2 simulant with $3.75 \mathrm{wt} \%$ uranium following SRAT cycle processing

Figure C- 9. Particle size number distribution for SB2 simulant with $7.5 \mathrm{i}$ wt $\%$ uranium 77

Figure C- 10. Particle size number distribution for SB2 simulant with $7.5 \mathrm{i}$ wt \% uranium following SRAT cycle processing

Figure C- 11. Particle size volume distribution for SB2 simulant with 7.5i wt \% uranium

Figure C- 12. Particle size volume distribution for SB2 simulant with 7.5i wt \% uranium following SRAT cycle processing

Figure C- 13. Particle size number distribution for SB2 simulant with 7.5ii wt \% uranium

Figure C- 14. Particle size number distribution for SB2 simulant with 7.5ii wt \% uranium following SRAT cycle processing

Figure C- 15. Particle size volume distribution for SB2 simulant with $7.5 \mathrm{ii}$ wt $\%$ uranium

Figure C-16. Particle size volume distribution for SB2 simulant with $7.5 \mathrm{ii}$ wt \% uranium following SRAT cycle processing

Figure C- 17. Particle size number distribution for SB2 simulant with $11.25 \mathrm{wt} \%$ uranium 86

Figure C- 18. Particle size number distribution for SB2 simulant with $11.25 \mathrm{wt} \%$ uranium following SRAT cycle processing

Figure C- 19. Particle size volume distribution for SB2 simulant with $11.25 \mathrm{wt} \%$ uranium

Figure C- 20. Particle size volume distribution for SB2 simulant with $11.25 \mathrm{wt} \%$ uranium following SRAT cycle processing

Figure C- 21. Particle size number distribution for SB2 simulant with $15 \mathrm{wt} \%$ uranium

Figure $\mathrm{C}-22$. Particle size number distribution for SB2 simulant with $15 \mathrm{wt} \%$ uranium following SRAT cycle processing

Figure C- 23. Particle size volume distribution for SB2 simulant with $15 \mathrm{wt} \%$ uranium

Figure C- 24. Particle size volume distribution for SB2 simulant with $15 \mathrm{wt} \%$ uranium following SRAT cycle processing

Figure D- 1. Preliminary Batch 0 Sludge Rheology Data

Figure D- 2. Pre-Run Batch 0 Sludge Rheology Data

Figure D- 3. Preliminary Batch 3.75 Sludge Rheology Data

Figure D- 4. Pre-Run Batch 3.75 Sludge Rheology Data

Figure D- 5. Preliminary Batch 7.5i Sludge Rheology Data

Figure D- 6. Pre-Run Batch 7.5i Sludge Rheology Data

Figure D- 7. Preliminary Batch 7.5ii Sludge Rheology Data

Figure D- 8. Resample Batch 7.5ii Sludge Rheology Data

Figure D- 9. Pre-Run Batch 7.5ii Sludge Rheology Data

Figure D- 10. Preliminary Batch 11.25 Sludge Rheology Data

Figure D- 11. Pre-Run Batch 11.25 Sludge Rheology Data

Figure D- 12. Preliminary Batch 15 Sludge Rheology Data

Figure D- 13. Pre-Run Batch 15 Sludge Rheology Data 
Figure E- 1. Batch 0 Sludge Regression - 1/22/04 104

Figure E- 2. Batch 0 Sludge Regression - 1/26/04 104

Figure E- 3. Batch 0 Sludge Regression - 2/17/04a 105

Figure E- 4. Batch 0 Sludge Regression - 2/17/04b 105

Figure E- 5. Batch 3.75 Sludge Regression - 1/22/04 106

Figure E- 6. Batch 3.75 Sludge Regression - 1/26/04 106

Figure E- 7. Batch 3.75 Sludge Regression - 2/23/04a 107

Figure E- 8. Batch 3.75 Sludge Regression - 2/23/04b 107

Figure E- 9. Batch 7.5i Sludge Regression - 1/22/04 108

Figure E- 10. Batch 7.5i Sludge Regression - 1/26/04 108

Figure E- 11. Batch 7.5i Sludge Regression - 2/9/04a 109

Figure E- 12. Batch 7.5i Sludge Regression - 2/9/04b 109

Figure E- 13. Batch 7.5ii Sludge Regression - 1/22/04 110

Figure E- 14. Batch 7.5ii Sludge Regression - 1/26/04 110

Figure E- 15. Batch 7.5ii Sludge Regression - 2/3/04a 111

Figure E- 16. Batch 7.5ii Sludge Regression - 2/3/04b 111

Figure E- 17. Batch 7.5ii Sludge Regression - 3/3/04a 112

Figure E- 18. Batch 7.5ii Sludge Regression - 3/3/04b 112

Figure E- 19. Batch 11.25 Sludge Regression - 1/22/04 113

Figure E- 20. Batch 11.25 Sludge Regression - 1/26/04a 113

Figure E- 21. Batch 11.25 Sludge Regression - 1/26/04b 114

Figure E- 22. Batch 11.25 Sludge Regression - 2/26/04a 115

Figure E- 23. Batch 11.25 Sludge Regression - 2/26/04b 115

Figure E- 24. Batch 15 Sludge Regression - 1/22/04 116

Figure E- 25. Batch 15 Sludge Regression - 1/26/04a 116

Figure E- 26. Batch 15 Sludge Regression - 1/26/04b 117

Figure E- 27. Batch 15 Sludge Regression - 3/1/04a 118

Figure E- 28. Batch 15 Sludge Regression - 3/1/04b 118

Figure F- 1. Batch 0 SRAT Product Rheology Data $\quad 120$

Figure F- 2. Batch 3.75-1 SRAT Product Rheology Data 120

Figure F- 3. Batch 3.75-2 SRAT Product Rheology Data 121

Figure F- 4. Batch 7.5i SRAT Product Rheology Data 121

Figure F- 5. Batch 7.5ii SRAT Product Rheology Data 122

Figure F- 6. Batch 11.25 SRAT Product Rheology Data 122

Figure F- 7. Batch 15 SRAT Product Rheology Data 123

Figure G- 1. Batch 0 SRAT Product Regression - Initial 126

Figure G- 2. Batch 0 SRAT Product Regression - Replicate 126

Figure G- 3. Batch 3.75 SRAT 1 Product Regression - Initial 127

Figure G- 4. Batch 3.75 SRAT 1 Product Regression - Replicate 127

Figure G- 5. Batch 3.75 SRAT 2 Product Regression - Initial 128

Figure G- 6. Batch 3.75 SRAT 2 Product Regression - Replicate 128

Figure G- 7. Batch 7.5i SRAT Product Regression - Initial 129

Figure G- 8. Batch 7.5i SRAT Product Regression - Replicate 129

Figure G- 9. Batch 7.5ii SRAT Product Regression - Initial 130

Figure G- 10. Batch 7.5ii SRAT Product Regression - Replicate $\quad 130$

Figure G- 11. Batch 11.25 SRAT Product Regression - Initial 131 
Figure G- 12. Batch 11.25 SRAT Product Regression - Replicate

Figure G- 13. Batch 15 SRAT Product Regression - Initial

132

Figure G- 14. Batch 15 SRAT Product Regression - Replicate 


\section{LIST OF TABLES}

Table 2-1. Phase 3 Slurry Elemental Characterization Data in mg/kg Slurry (Std. Dev., $\%$ RSD)

Table 2-2. Phase 3 Supernate Elemental Characterization

Table 2-3. Phase $3 \mathrm{Wt} \%$ Total and Soluble Solids (Std. Dev., \%RSD)

Table 2-4. Adjustment Factors for Trim Reagents Shown in Appendix A Recipes

Table 2-5. Elements in the SRAT Cycle Feeds in Wt \% of Total Solids (Std. Dev., \%RSD)

Table 2-6. Ratio of Iron to Manganese in SRAT Cycle Feeds

Table 2-7. Soluble Sodium and Uranium in SRAT Cycle Feeds in $\mathrm{Wt} \%$ of Total Solids (Std. Dev, \%RSD)

Table 2-8. Supernate Anion Data in mg/kg Slurry (Std. Dev., \%RSD)

Table 2-9. Acid Calculation Inputs for TIC

Table 2-10. Uranium Sludges $\mathrm{pH}$ and Base Equivalents to $\mathrm{pH} 7$

Table 2-11. SRAT Cycle Feeds Wt \% Solids (Std. Dev., \%RSD)

Table 2-12. SRAT Cycle Feeds Particle Size Analyses (values in $\mathrm{m \mu}$ )

Table 2-13. Measured Slurry and Supernate Densities $(\mathrm{g} / \mathrm{mL})$

Table 2-14. Dates of Pre-Run Sludge Rheology Measurements

Table 2-15. Sludge Bingham Plastic Model Parameters

Table 3-1. Summary of Inputs and Outputs for Uranium Sludge SRAT Cycle Acid

Calculations
Table 3-2. DWPF and SRNL Scale SRAT Processing Parameters and Target Acid Addition Amounts

Table 3-3. Weight Percent Solids, Density, and Final pH of the SRAT Cycle Products (Std.
Dev. and \%RSD)

Table 3-3. Weight Percent Solids, Density, and Final pH of the SRAT Cycle Products (Std.
Dev. and \%RSD)

Table 3-4. Measured Ion Chromatography Anions in the Post Dewater SRAT Material (mg/kg slurry) 26

Table 3-5. Measured Ion Chromatography Anions in the SRAT Products (mg/kg slurry) 27

Table 3-6. Calculated SRAT Cycles Nitrite Destruction, Nitrite to Nitrate Conversion, and Percent Formate Destruction

Table 3-7. Slurry Elements Measured in the SRAT Products in $\mathrm{mg} / \mathrm{kg}$ slurry (Std. Dev., $\%$ RSD)

Table 3-8. Supernate Elements Measured in the SRAT Products in $\mathrm{mg} / \mathrm{kg}$ slurry (Std. Dev., $\%$ RSD)

Table 3-9. Percent Soluble of Select Elements in SRAT Products 31

Table 3-10. Observed SRAT Cycle Feed Volume Change Factors 32

Table 3-11. SRAT Cycle Products Particle Size Analyses (values in $\mu \mathrm{m}$ ) 36

Table 3-12. Dates for SRAT Product Rheological Measurements 36

Table 3-13. SRAT product Bingham plastic model parameters 38

Table B- 1. Recipe Calculation for $0 \mathrm{wt} \%$ Uranium Sludge Batch 2 Simulant 64

Table B- 2. Recipe Calculation for $3.75 \mathrm{wt} \%$ Uranium Sludge Batch 2 Simulant 65

Table B- 3. Recipe Calculation for $7.5 \mathrm{wt} \%$ Uranium Sludge Batch 2 Simulant 66

Table B- 4. Recipe Calculation for 11.25 wt \% Uranium Sludge Batch 2 Simulant 67

Table B- 5. Recipe Calculation for 15 wt \% Uranium Sludge Batch 2 Simulant 68 


\section{LIST OF ACRONYMS}

$\AA$

ACTL

ASP

cfm

CETL

CPC

DWPF

eq/L

GC

IC

ICP-AES

$\mathrm{L}$

M

$\mathrm{mn}$

$\mathrm{MnO}_{2}$

$\mathrm{mv}$

PNNL

RSD

SB2

$\mathrm{sccm}$

scfm

SME

SRAT

SRNL

Std. Dev.

TIC

TTQAP

wt $\%$

XRD
Angstrom $\left(10^{-10}\right.$ meters $)$

Aiken County Technical Laboratory

Analytical Study Plan

cubic feet per minute

Clemson Environmental Technology Laboratory

Chemical Processing Cell

Defense Waste Processing Facility

Equivalents per liter

Gas Chromatograph

Ion Chromatography

Inductively Couple Plasma - Atomic Emission Spectroscopy

Liter

Molar

Mean diameter of the number distribution

Manganese dioxide

Mean diameter of the volume distribution

Pacific Northwest National Laboratory

Relative Standard Deviation

Sludge Batch 2

Standard cubic centimeters

Standard cubic feet per minute

Slurry Mix Evaporator

Sludge Receipt and Adjustment Tank

Savannah River National Laboratory

Standard Deviation

Total Inorganic Carbon

Task Technical and Quality Assurance Plan

Weight percent

$\mathrm{X}$-ray Diffraction 


\subsection{INTRODUCTION AND BACKGROUND}

The Defense Waste Processing Facility (DWPF) began processing Sludge Batch 2 (SB2) in December of 2001. Since the introduction of the first SRAT batch of SB2, processing issues have been observed in the Sludge Receipt and Adjustment Tank (SRAT), Slurry Mix Evaporator (SME), Melter Feed Tank (MFT) and the melter. These issues coincided with the start of Batch 209, the first full batch from SB2 ${ }^{\mathrm{a} 5}$. The issues involved the ability to transfer process slurries and feed the melter, difficulty maintaining heat transfer in the SME, and degradation of the operation of the melter. One of the primary differences between Sludge Batch 2 and the previous Sludge Batches is the increased content of uranium.

The Savannah River National Laboratory (SRNL) was requested by DWPF via Technical Task Request HLW/DWPF/TTR-02-0035 to determine if the processing issues are related to the elevated levels of uranium in $\mathrm{SB}^{1}$. The work reported here is intended to address only a portion of TTR-0035, specifically the impact of uranium on Sludge Batch 2. This work is governed by a Task Technical and Quality Assurance Plan (TTQAP) ${ }^{2}$ and an Analytical Study Plan (ASP) ${ }^{3}$.

SRNL conducted small-scale tests designed to determine the effect of different levels of uranium on sludge processing at the same redox and stoichiometric factor, 0.20 and $130 \%$ respectively. Samples used a series of uranium levels in a simulant of SB2. The samples with different uranium contents were compared with each other before and after undergoing a simulated SRAT cycle process.

Documented in this report are:

- Preparation and evaluation of SB2 simulants containing a series of depleted uranium concentrations.

- Demonstration of the DWPF SRAT process using SB2 based simulants with varying levels of uranium.

- Rheological properties of uranium containing SB2 simulants before and after SRAT processing.

- Comparison of the rheology with other SB2 simulants.

- Resolution of several issues raised in the previous work with uranium ${ }^{5}$.

${ }^{a}$ Note: Batch 208 was actually the first batch of SB2. 
WSRC-TR-2004-00206

Revision 0

This page intentionally left blank. 


\subsection{DEPLETED URANIUM SIMULANTS}

\subsection{Approach}

\subsubsection{Simulant Preparation}

A series of six sludge simulants with five levels of depleted uranium were prepared for this study. Samples were targeted with no uranium content, 3.75, 7.5, 11.25, and $15 \mathrm{wt} \%$ of uranium (total dried solids basis). The $7.5 \mathrm{wt} \%$ target sludge corresponds to the approximate level of uranium determined to be in the actual Sludge Batch 2 feed $^{4}$. The $15 \mathrm{wt} \%$ level represented a high concentration to determine if increasing the content of uranium impacts simulant properties during Chemical Processing Cell (CPC) processing. The initial work conducted in this area indicated the $0-15 \mathrm{wt} \%$ interval may have bracketed the range of uranium content that adversely impacts the physical properties of the slurry ${ }^{5}$. In light of this, two additional uranium levels were included in this study to better understand this phenomenon. To evaluate the degree of variability in sludge makeup, duplicate center points targeted at $7.5 \mathrm{wt} \%$ uranium were prepared. Additionally, one sludge, at nominally $3.75 \mathrm{wt} \%$ uranium, was processed in replicate SRAT cycles.

The sludge batch preparations are designated Batch 0 , for the batch without uranium; Batch 3.75 , for the batch containing nominally $3.75 \mathrm{wt} \%$ uranium; Batch $7.5 \mathrm{i}$, the first nominally $7.5 \mathrm{wt} \%$ uranium batch; Batch 7.5ii, the second nominally $7.5 \mathrm{wt} \%$ uranium batch; Batch 11.25 , for the batch containing nominally $11.25 \mathrm{wt} \%$ uranium; and Batch 15 , for the batch containing nominally $15 \mathrm{wt} \%$ uranium.

Uranium was added during Phase 1 of the preparation protocol ${ }^{\mathrm{b}, 6}$ and precipitated along with iron (Fe) and nickel $(\mathrm{Ni})$ in the presence of manganese dioxide $\left(\mathrm{MnO}_{2}\right)$. Appendix A contains a sample sludge makeup procedure, and the recipes for targeted compositions these sludge preparations are given in Appendix B. As the uranium content increased, there was a proportional reduction in the metal ion and oxide additions of the other reagents with the exception of sodium $(\mathrm{Na})$. Reagents added for their anion contribution were held constant throughout the recipes.

During precipitation the slurry temperature was maintained between $35-40^{\circ} \mathrm{C}$ with a jacketed vessel connected to a recirculating water bath. Sludge was transferred from the jacketed preparation vessel to a bottle and allowed to settle. Phase 2 sampling was not conducted. Phase 3 of the preparation began when the settled sludge volume dropped to approximately $1 \mathrm{~L}$, the supernate was removed and the remaining slurry agitated with $3.6 \mathrm{~L}$ of $\mathrm{pH} 10.5$ adjusted water for 30 minutes and allowed to settle again. This process was repeated for four consecutive washes until the soluble solids value was below $0.15-0.20 \mathrm{wt} \%$ and/or the soluble $\mathrm{Na}$ concentration was below $0.025 \mathrm{M}$. Table $2-1$ provides the inductively coupled plasma - atomic emission spectroscopy (ICP-AES) data for some key elements.

The Batch 7.5i Phase 3 slurry was more dilute than the Batch 7.5ii Phase 3 slurry. An average of the Fe, $\mathrm{Mn}, \mathrm{Ni}$, and $\mathrm{U}$ ratios between Batch 7.5i and Batch 7.5ii yields 0.95 , while a ratio of the total solids between these two batches yields 0.92 , a reasonably close agreement. Differences observed in the rheology of these two batches will be discussed in Section 2.1.2 of this report.

\footnotetext{
${ }^{\mathrm{b}}$ Phase 1 involves precipitation of $\mathrm{Mn}, \mathrm{Fe}$, and Ni metal salts as hydroxides/oxides. Phase 2 involves sampling and analysis for wt \% total solids and $\mathrm{Fe}, \mathrm{Mn}, \mathrm{Na}$, and $\mathrm{Ni}$ concentrations. Phase 3 involves multiple washing of the slurry. Phase 4 involves the addition of all remaining trim reagents. Phase 5 is the final analysis of the slurry.
} 
Table 2-1. Phase 3 Slurry Elemental Characterization Data in mg/kg Slurry (Std. Dev., \%RSD)

\begin{tabular}{|c|c|c|c|c|}
\hline Batch No. & Fe & Mn & $\mathbf{N i}$ & $\mathbf{U}$ \\
\hline 0 & $\begin{array}{c}52,400 \\
(1160,2.2)\end{array}$ & $\begin{array}{c}5420 \\
(70,1.3)\end{array}$ & $\begin{array}{c}3080 \\
(56,1.8)\end{array}$ & $<1000$ \\
\hline 3.75 & $\begin{array}{c}49,400 \\
(250,0.5)\end{array}$ & $\begin{array}{c}5300 \\
(15,0.3)\end{array}$ & $\begin{array}{c}2990 \\
(68,2.3)\end{array}$ & $\begin{array}{c}8690 \\
(190,2.2)\end{array}$ \\
\hline $7.5 \mathrm{i}$ & $\begin{array}{c}45,700 \\
(150,0.3)\end{array}$ & $\begin{array}{c}4930 \\
(35,0.7)\end{array}$ & $\begin{array}{c}2770 \\
(10,0.4)\end{array}$ & $\begin{array}{c}15,900 \\
(58,0.4)\end{array}$ \\
\hline 7.5ii & $\begin{array}{c}47,700 \\
(210,0.4)\end{array}$ & $\begin{array}{c}5010 \\
(12,0.2)\end{array}$ & $\begin{array}{c}3080 \\
(280,9.2)\end{array}$ & $\begin{array}{c}16,600 \\
(58,0.3)\end{array}$ \\
\hline 11.25 & $\begin{array}{c}45,300 \\
(150,0.3)\end{array}$ & $\begin{array}{c}4860 \\
(32,0.7)\end{array}$ & $\begin{array}{c}2760 \\
(120,4.4)\end{array}$ & $\begin{array}{c}25400 \\
(950,3.8)\end{array}$ \\
\hline 15 & $\begin{array}{c}38,800 \\
(100,0.3)\end{array}$ & $\begin{array}{c}3980 \\
(12,0.3)\end{array}$ & $\begin{array}{c}2310 \\
(21,0.9)\end{array}$ & $\begin{array}{c}31,500 \\
(830,2.6)\end{array}$ \\
\hline
\end{tabular}

Table 2-2 provides the soluble $\mathrm{Na}$ and $\mathrm{U}$ levels measured in the supernate liquid of the fourth wash, while Table 2-3 summarizes the wt \% total and soluble solids.

Table 2-2. Phase 3 Supernate Elemental Characterization

Data in mg/L Supernate (Std. Dev., \%RSD)

\begin{tabular}{ccc}
\hline Batch No. & Na & U \\
\hline 0 & $566(6,1.1)$ & $<10$ \\
3.75 & $337(8,2.3)$ & $<10$ \\
$7.5 \mathrm{i}$ & $325(10,2.9)$ & $<10$ \\
$7.5 \mathrm{ii}$ & $447(5,1.1)$ & $<10$ \\
11.25 & $404(20,4.9)$ & $<10$ \\
15 & $498(8,1.5)$ & $<10$ \\
\hline
\end{tabular}

Table 2-3. Phase 3 Wt \% Total and Soluble Solids (Std. Dev., \%RSD)

\begin{tabular}{cccl}
\hline Batch No. & \multicolumn{2}{c}{ Total Solids } & \multicolumn{2}{l}{ Soluble Solids } \\
\hline 0 & 10.2 & $(0.15,1.5)$ & $0.11(0.01,10.2)$ \\
3.75 & 10.8 & $(0.26,2.4)$ & $0.11(0.01,5.1)$ \\
$7.5 \mathrm{i}$ & 10.9 & $(0.10 .0 .9)$ & $0.11(0.01,9.1)$ \\
$7.5 \mathrm{ii}$ & 11.8 & $(0.21,1.8)$ & $0.13(0.01,4.6)$ \\
11.25 & 12.5 & $(0.12,0.9)$ & $0.10 \quad(0.01,5.6)$ \\
15 & 12.0 & $(0.25,2.1)$ & $0.12 \quad(0.02,13.1)$ \\
\hline
\end{tabular}


Following characterization of the sludges prepared during Phase 3, the remaining trim reagents were added separately, with 15 minutes agitation between additions, to each slurry batch (refer to Appendix A). It was necessary to adjust the recipe trim additions to account for the solids removed during Phase 3 sampling. The following adjustment factors were calculated for each recipe trim component shown in Table 2-4.

Table 2-4. Adjustment Factors for Trim Reagents Shown in Appendix A Recipes

\begin{tabular}{cc}
\hline Batch No. & Adjustment Factor \\
\hline 0 & 0.9471 \\
3.75 & 0.9484 \\
$7.5 \mathrm{i}$ & 0.9481 \\
$7.5 \mathrm{ii}$ & 0.9474 \\
11.25 & 0.9494 \\
15 & 0.9544 \\
\hline
\end{tabular}

\subsubsection{Rheology}

Rheological characterizations of sludges and SRAT products were accomplished using the Haake RV20/M5 rheometer located in the 773-A, B-111 radiohood. Rheological measurements were not made on, nor a sample pulled, at the minimum $\mathrm{pH}$ point of the SRAT cycle due to the smaller scale of these SRAT cycles than those in previous work ${ }^{5}$. Measurements were made with a viscosity standard to ensure that the rheometer was performing within expected limits. No issues with rheometer performance were noted during the test period. Flow curve data given in this report have not been corrected for slip, non-Newtonian behavior, etc.

Slurry samples containing depleted uranium were characterized with the MV1 concentric cylinder sensor. A shear rate range of $0-500 /$ second was used for the routine measurements. The shear rate was ramped from $0-500 / \mathrm{s}$ over five minutes, held at 500/s for one-half minute, and then ramped down from $500-0 / \mathrm{sec}$ over five minutes. (A few tests designed to look at rheological anomalies in some of the samples were performed using a smaller shear rate range and shorter times.) Rheological measurements were made at $25^{\circ} \mathrm{C}$. A jacket around the sample beaker was connected to a constant temperature, circulating, water bath to maintain temperature control.

Sufficient sample volume was provided to make two independent measurements without reusing any sample, except in the case of the SRAT product from the second run with the Batch 3.75 simulant. In that one case, the replicate measurement used a small amount of material recovered from the initial measurement mixed with fresh material. None of the DU slurry samples were observed to form a clear supernate layer after fifteen minutes at rest. Therefore, partial settling of slurry solids during the rheological measurements was not considered to be an issue.

Rheological data were fitted to the Bingham plastic fluid rheological equation.

$$
\text { Bingham plastic fluid: } \quad \tau=\tau_{o, B}+\eta_{B} \cdot D
$$

Where $\tau$ is the shear stress, $\mathrm{D}$ is the shear rate, $\tau_{\mathrm{o}, \mathrm{B}}$ is the Bingham plastic yield stress, and $\eta_{\mathrm{B}}$ is the plastic viscosity, or consistency. Rheometer data for the shear stress are typically expressed in Pascals, $\mathrm{Pa}$. One Pa corresponds to 10 dynes $/ \mathrm{cm}^{2}$. The Bingham plastic equation tends to give conservative yield stress values, i.e. values greater than the true yield stress of the sample. Regressions were made using 
the data analysis tools in Microsoft Excel. Up ramp and down ramp flow curve data were not coincident. Therefore, the up and down ramp data were fitted separately. Significantly nonlinear regions of the flow curves were excluded before performing the regressions.

\subsection{Sludge Preparation Results}

Following trim reagent additions, each completed sludge was sampled, and chemical and physical characterizations were performed. Results of the characterizations are given in the sections below.

\subsubsection{Chemical Characterization}

Samples of the final sludge compositions were submitted for ICP-AES analysis to look at total as well as soluble elemental composition. The total analyses are shown in Table 2-5 while Table 2-7 contains the two soluble components, $\mathrm{Na}$ and $\mathrm{U}$, which were measured. The final wt $\% \mathrm{U}$ values varied from the target values by an average of $9 \%$ with a standard deviation of $2 \%$ and all final $U$ concentrations were lower than the target values while still spanning a range of $U$ concentrations from zero to nearly $14 \%$. Throughout this report, the batches will be referenced based upon their "target" rather than "actual" uranium content for simplicity, but Table 2-5 can be referred to for the actual values. The soluble uranium in the feeds was negligible, but due to refinement of the detection limits since the initial data given in Table 2-2, the level was measurable, on the order of 1-3 ppm. Previous work ${ }^{5}$ had an actual U range from zero to $11.4 \mathrm{wt} \%$, also below the target values, but soluble $\mathrm{U}$ levels in the starting feeds were not measured.

The $\mathrm{Al}$ values were found to be higher than anticipated when the feeds were analyzed. This resulted from the use of $\mathrm{Al}(\mathrm{OH})_{3} \cdot \mathrm{nH}_{2} \mathrm{O}, 32-35 \% \mathrm{H}_{2} \mathrm{O}$, to satisfy the $\mathrm{Al}(\mathrm{OH})_{3}$ recipe request. Apparently this reagent is not $65-68 \% \mathrm{Al}(\mathrm{OH})_{3}$ as was assumed in the calculations, but $65-68 \% \mathrm{Al}_{2} \mathrm{O}_{3}$, resulting in an excess of $\mathrm{Al}$ in the final sludges.

A comparison of Batch 7.5i and Batch 7.5ii data in Table 2-5 indicates that the former batch is enriched in many Phase 4 reagents ( $\mathrm{Al}, \mathrm{Ca}, \mathrm{Cu}, \mathrm{K}$, and $\mathrm{Mg}$ ) and reduced in Phase 1 species (Fe, $\mathrm{Mn}, \mathrm{Ni}$, and $\mathrm{U}$ ). The Phase 4 trim chemicals were added to produce consistent final total solids values. It is possible that more of the Batch $7.5 \mathrm{i}$ was removed prior to trimming than was realized. There were difficulties in weighing the large sludge batches in the hood, hence they had to be bagged for removal from the hood prior to measurement - this operation inserted a degree of uncertainty in the measured masses removed through sampling prior to trim reagent addition. 
Table 2-5. Elements in the SRAT Cycle Feeds in Wt \% of Total Solids (Std. Dev., \%RSD)

\begin{tabular}{|c|c|c|c|c|c|c|}
\hline Element & Batch 0 & Batch 3.75 & Batch 7.5i & Batch 7.5ii & Batch 11.25 & Batch 15 \\
\hline Al & $\begin{array}{c}10.9 \\
(0.2,1.5)\end{array}$ & $\begin{array}{c}10.3 \\
(0.2,1.6)\end{array}$ & $\begin{array}{c}9.83 \\
(0.07,0.7)\end{array}$ & $\begin{array}{c}9.48 \\
(0.20,2.2)\end{array}$ & $\begin{array}{c}8.63 \\
(0.05,0.6)\end{array}$ & $\begin{array}{c}8.12 \\
(0.08,1.0)\end{array}$ \\
\hline $\mathbf{C a}$ & $\begin{array}{c}2.24 \\
(0.03,1.3)\end{array}$ & $\begin{array}{c}1.98 \\
(0.02,1.1)\end{array}$ & $\begin{array}{c}2.10 \\
(0.03,1.5)\end{array}$ & $\begin{array}{c}2.07 \\
(0.02,1.2)\end{array}$ & $\begin{array}{c}1.91 \\
(0.03,1.8)\end{array}$ & $\begin{array}{c}1.72 \\
(0.03,1.6)\end{array}$ \\
\hline $\mathbf{C u}$ & $\begin{array}{c}0.118 \\
(0.014,12)\end{array}$ & $\begin{array}{c}0.122 \\
(0.004,3.6)\end{array}$ & $\begin{array}{c}0.109 \\
(0.005,4.8)\end{array}$ & $\begin{array}{c}0.0796 \\
(0.0014,1.7)\end{array}$ & $\begin{array}{c}0.0981 \\
(0.0045,4.5)\end{array}$ & $\begin{array}{c}0.0912 \\
(0.0026,2.8)\end{array}$ \\
\hline $\mathbf{F e}$ & $\begin{array}{c}21.0 \\
(0.02,0.1)\end{array}$ & $\begin{array}{c}19.2 \\
(0.6,2.9)\end{array}$ & $\begin{array}{c}18.3 \\
(0.4,1.9)\end{array}$ & $\begin{array}{c}19.3 \\
(0.1,0.4)\end{array}$ & $\begin{array}{c}17.7 \\
(0.3,1.5)\end{array}$ & $\begin{array}{c}16.6 \\
(0.1,0.4)\end{array}$ \\
\hline $\mathbf{K}$ & $\begin{array}{c}0.0417 \\
(0.0020,4.8)\end{array}$ & $\begin{array}{c}0.0463 \\
(0.0005,1.0)\end{array}$ & $\begin{array}{c}0.0755 \\
(0.0022,2.9)\end{array}$ & $\begin{array}{c}0.0667 \\
(0.0011,1.7)\end{array}$ & $\begin{array}{c}0.0616 \\
(0.0013,2.2)\end{array}$ & $\begin{array}{c}0.0943 \\
(0.0028,3.0)\end{array}$ \\
\hline Mg & $\begin{array}{c}0.109 \\
(0.005,4.6)\end{array}$ & $\begin{array}{c}0.103 \\
(0.003,3.1)\end{array}$ & $\begin{array}{c}0.0937 \\
(0.002,2.5)\end{array}$ & $\begin{array}{c}0.0869 \\
(0.0002,0.2)\end{array}$ & $\begin{array}{c}0.0856 \\
(0.0020,2.3)\end{array}$ & $\begin{array}{c}0.0790 \\
(0.0017,2.1)\end{array}$ \\
\hline Mn & $\begin{array}{c}2.29 \\
(0.01,0.2)\end{array}$ & $\begin{array}{c}2.08 \\
(0.03,1.5)\end{array}$ & $\begin{array}{c}2.00 \\
(0.05,2.3)\end{array}$ & $\begin{array}{c}2.10 \\
(0.01,0.3)\end{array}$ & $\begin{array}{c}1.91 \\
(0.04,1.9)\end{array}$ & $\begin{array}{c}1.78 \\
(0.01,0 .\end{array}$ \\
\hline $\mathbf{N a}$ & $\begin{array}{c}5.97 \\
(0.09,1.5)\end{array}$ & $\begin{array}{c}6.37 \\
(0.26,4.0)\end{array}$ & $\begin{array}{c}6.66 \\
(0.15,2.3)\end{array}$ & $\begin{array}{c}6.83 \\
(0.14,2.0)\end{array}$ & $\begin{array}{c}6.83 \\
(0.19,2.7)\end{array}$ & $\begin{array}{c}7.20 \\
(0.05,0.7)\end{array}$ \\
\hline $\mathbf{N i}$ & $\begin{array}{c}1.21 \\
(0.002,0.2)\end{array}$ & $\begin{array}{c}1.08 \\
(0.05,4.2)\end{array}$ & $\begin{array}{c}1.05 \\
(0.02,2.1)\end{array}$ & $\begin{array}{c}1.10 \\
(0.01,0.8)\end{array}$ & $\begin{array}{c}0.999 \\
(0.016,1.6)\end{array}$ & $\begin{array}{c}0.926 \\
(0.003,0.3)\end{array}$ \\
\hline $\mathbf{S}$ & $\begin{array}{c}0.211 \\
(0.004,2.0)\end{array}$ & $\begin{array}{c}0.194 \\
(0.005,2.4)\end{array}$ & $\begin{array}{c}0.197 \\
(0.003,1.7)\end{array}$ & $\begin{array}{c}0.213 \\
(0.004,1.8)\end{array}$ & $\begin{array}{c}0.168 \\
(0.001,0.7)\end{array}$ & $\begin{array}{c}0.174 \\
(0.004,2.1)\end{array}$ \\
\hline $\mathbf{U}$ & $<0.074$ & $\begin{array}{c}3.46 \\
(0.04,1.0)\end{array}$ & $\begin{array}{c}6.52 \\
(0.12,1.8)\end{array}$ & $\begin{array}{c}7.02 \\
(0.09,1.2)\end{array}$ & $\begin{array}{c}10.2 \\
(0.05,0.5)\end{array}$ & $\begin{array}{c}13.7 \\
(0.04,0.3)\end{array}$ \\
\hline
\end{tabular}

$\dagger 1100^{\circ} \mathrm{C}$

From the data in Table 2-5 the Fe:Mn ratio for each of the sludge batches can be calculated. These ratios are found in Table 2-6. There was good consistency between theses ratios for the various batch preparations. The targeted Fe:Mn was 9.8. The Fe:Mn in the previous study varied from $7.4-8.2^{5}$.

Table 2-6. Ratio of Iron to Manganese in SRAT Cycle Feeds

\begin{tabular}{cc}
\hline Batch No. & Fe:Mn \\
\hline 0 & 9.2 \\
3.75 & 9.3 \\
$7.5 \mathrm{i}$ & 9.1 \\
$7.5 \mathrm{ii}$ & 9.2 \\
11.25 & 9.3 \\
15 & 9.3 \\
\hline
\end{tabular}


WSRC-TR-2004-00206

Revision 0

Table 2-7. Soluble Sodium and Uranium in SRAT Cycle Feeds in Wt\% of Total Solids (Std. Dev, \%RSD)

\begin{tabular}{ccccccc}
\hline \multirow{2}{*}{ Element } & Batch 0 & Batch 3.75 & Batch 7.5i & Batch 7.5ii & Batch 11.25 & Batch 15 \\
\hline $\mathbf{N a}$ & 6.74 & 6.57 & 6.86 & 6.76 & 6.70 & 6.91 \\
& $(0.07,1.1)$ & $(0.08,1.2)$ & $(0.06,0.9)$ & $(0.10,1.4)$ & $(0.08,1.1)$ & $(0.04,0.6)$ \\
& & & & & & \\
$\mathbf{U}$ & $<3.54 \mathrm{E}-04$ & $4.17 \mathrm{E}-04$ & $8.31 \mathrm{E}-04$ & $4.34 \mathrm{E}-04$ & $7.52 \mathrm{E}-04$ & $5.32 \mathrm{E}-04$ \\
& & $(0.03 \mathrm{E}-04,0.6)$ & $(4.95 \mathrm{E}-04,60)$ & $(0.20 \mathrm{E}-04,4.7)$ & $(0.27 \mathrm{E}-04,36)$ & $(0.63 \mathrm{E}-04,12)$ \\
\hline
\end{tabular}

Note, there was significantly more measured soluble sodium for Batch 0 than total sodium, indicating that one or both of these numbers may have more error than the other Batch data sets.

Samples of each slurry were also submitted for ion chromatograph (IC) analysis of formate, nitrite, nitrate and sulfate. In general the precision of these measurements was poor with relative standard deviations approaching 10\% in many instances. For the SRAT acid calculations, an average nitrite and nitrate concentration was selected and used for all of the batches. Formate was not included in the recipes and no formate was measured in the final sludges.

Table 2-8. Supernate Anion Data in mg/kg Slurry (Std. Dev., \%RSD)

\begin{tabular}{cllll}
\hline Batch No. & Formate & \multicolumn{1}{c}{ Nitrite } & \multicolumn{1}{c}{ Nitrate } & Sulfate \\
\hline 0 & $<8$ & $8990(230,2.5)$ & $4330(130,3.0)$ & $1500(160,5.2)$ \\
3.75 & $<8$ & $9010(0,0)$ & $3890(50,1.3)$ & $1230(6,0.5)$ \\
$7.5 \mathrm{i}$ & $<8$ & $7450(360,4.8)$ & $3210(170,5.4)$ & $1260(110,9.0)$ \\
$7.5 \mathrm{ii}$ & $<8$ & $8260(670,8.2)$ & $3730(310,8.2)$ & $1290(11,0.9)$ \\
11.25 & $<79$ & $8340(780,9.4)$ & $3670(360,9.8)$ & $1240(110,8.7)$ \\
15 & $<79$ & $8210(110,1.4)$ & $3810(60.1 .5)$ & $1110(110,10)$ \\
Average & NA & $\mathbf{8 3 8 0}$ & $\mathbf{3 7 7 0}$ & \\
\hline
\end{tabular}

Initial samples submitted for total inorganic carbon (TIC) had very poor precision due to sub-sampling issues with heterogeneous particles; hence the mass of carbon was calculated from the added $\mathrm{CaCO}_{3}$ and $\mathrm{Na}_{2} \mathrm{CO}_{3}$ for each sludge slurry. Table 2-9 shows the inputs for each sludge batch, the mass of the final slurry, and the calculated carbon concentration used in the acid calculation for each batch's SRAT cycle.

Table 2-9. Acid Calculation Inputs for TIC

\begin{tabular}{ccccc}
\hline Batch No. & $\begin{array}{c}\text { Mass of } \mathbf{C a C O}_{\mathbf{3}} \\
\mathbf{( g )}\end{array}$ & $\begin{array}{c}\text { Mass of } \mathbf{N a}_{\mathbf{2}} \mathbf{C O}_{\mathbf{3}} \\
(\mathbf{g})\end{array}$ & $\begin{array}{c}\text { Mass of Slurry } \\
(\mathbf{g})\end{array}$ & $\begin{array}{c}\text { Mass of Carbon } \\
(\mathbf{m g} / \mathbf{k g} \text { slurry })\end{array}$ \\
\hline 0 & 12.218 & 4.514 & 1067.98 & 1852 \\
3.75 & 11.506 & 4.526 & 1088.60 & 1740 \\
$7.5 \mathrm{i}$ & 10.722 & 4.521 & 1100.88 & 1640 \\
$7.5 \mathrm{ii}$ & 10.763 & 4.517 & 1101.02 & 1638 \\
11.25 & 10.057 & 4.526 & 1104.64 & 1557 \\
15 & 9.379 & 4.550 & 1193.12 & 1375 \\
\hline
\end{tabular}

Solids were isolated from each slurry, dried at $110^{\circ} \mathrm{C}$, and submitted for x-ray diffraction (XRD) analysis. The spectra from these analyses are shown in Figure 2-1 through Figure 2-6. The uranium was added to the recipe as uranyl nitrate, $\mathrm{UO}_{2}\left(\mathrm{NO}_{3}\right)_{2} \bullet 6 \mathrm{H}_{2} \mathrm{O}$. Following precipitation the identified sludge species was a hydrated uranate $($ Clarkeite $), \mathrm{Na}\left(\mathrm{UO}_{2}\right) \mathrm{O}(\mathrm{OH})$ in each of the sludge preparations. The 
broadness of the Clarkeite peaks is consistent with the less than completely crystalline nature of the species. The absence of the hydroxylapatite, $\mathrm{Ca}_{5}\left(\mathrm{PO}_{4}\right)_{3}(\mathrm{OH})$ or $3 \mathrm{Ca}_{3}\left(\mathrm{PO}_{4}\right)_{2} \cdot \mathrm{Ca}(\mathrm{OH})_{2}$, a species added during the final Phase 4 trimming of each slurry, in the Batch 7.5 through Batch 15 spectra is thought to be due to a combination of its decreasing concentration as the $\mathrm{U}$ concentration increased, and its being obscured by other phases.

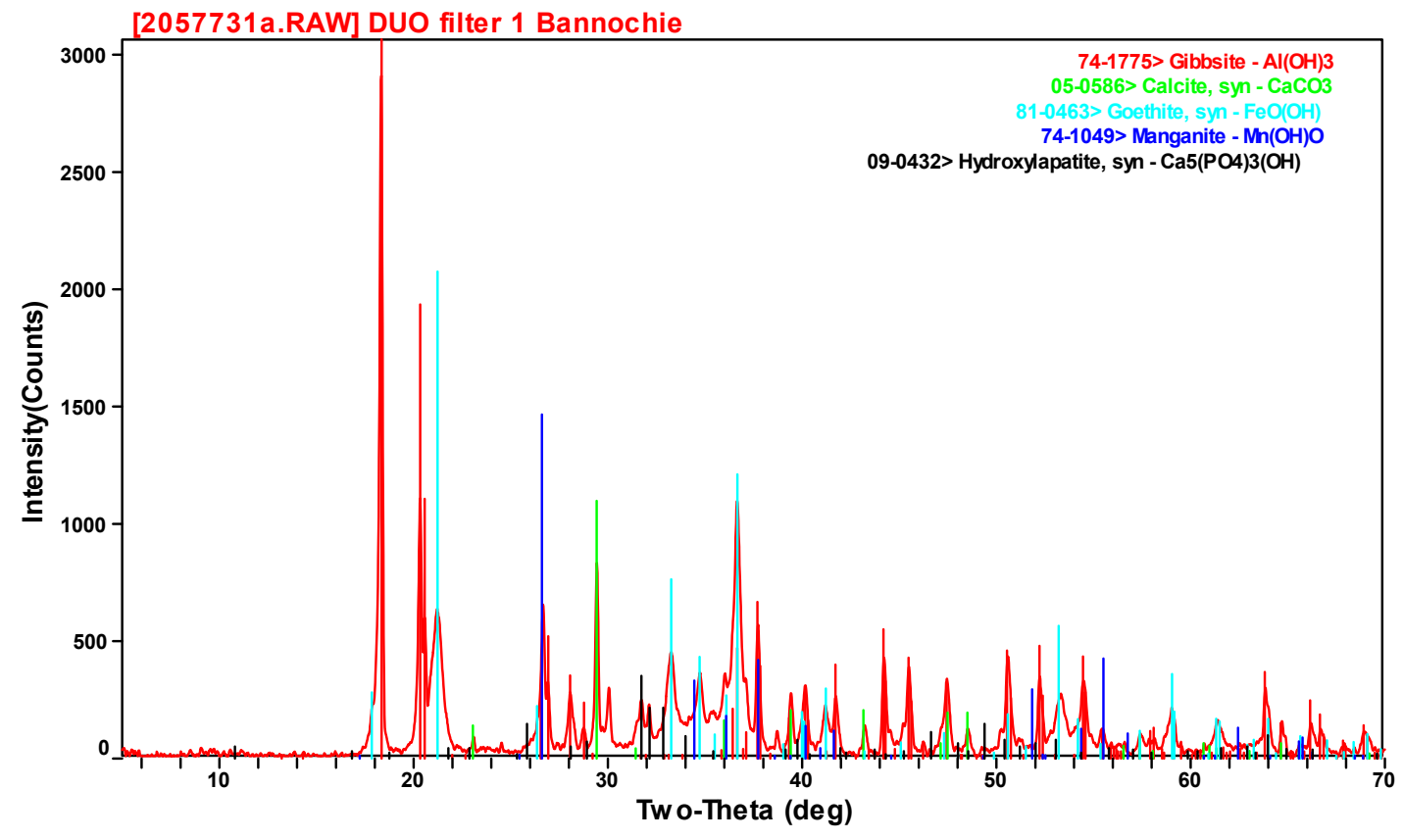

Figure 2-1. XRD Spectra of the Batch 0 SB2 Simulant 


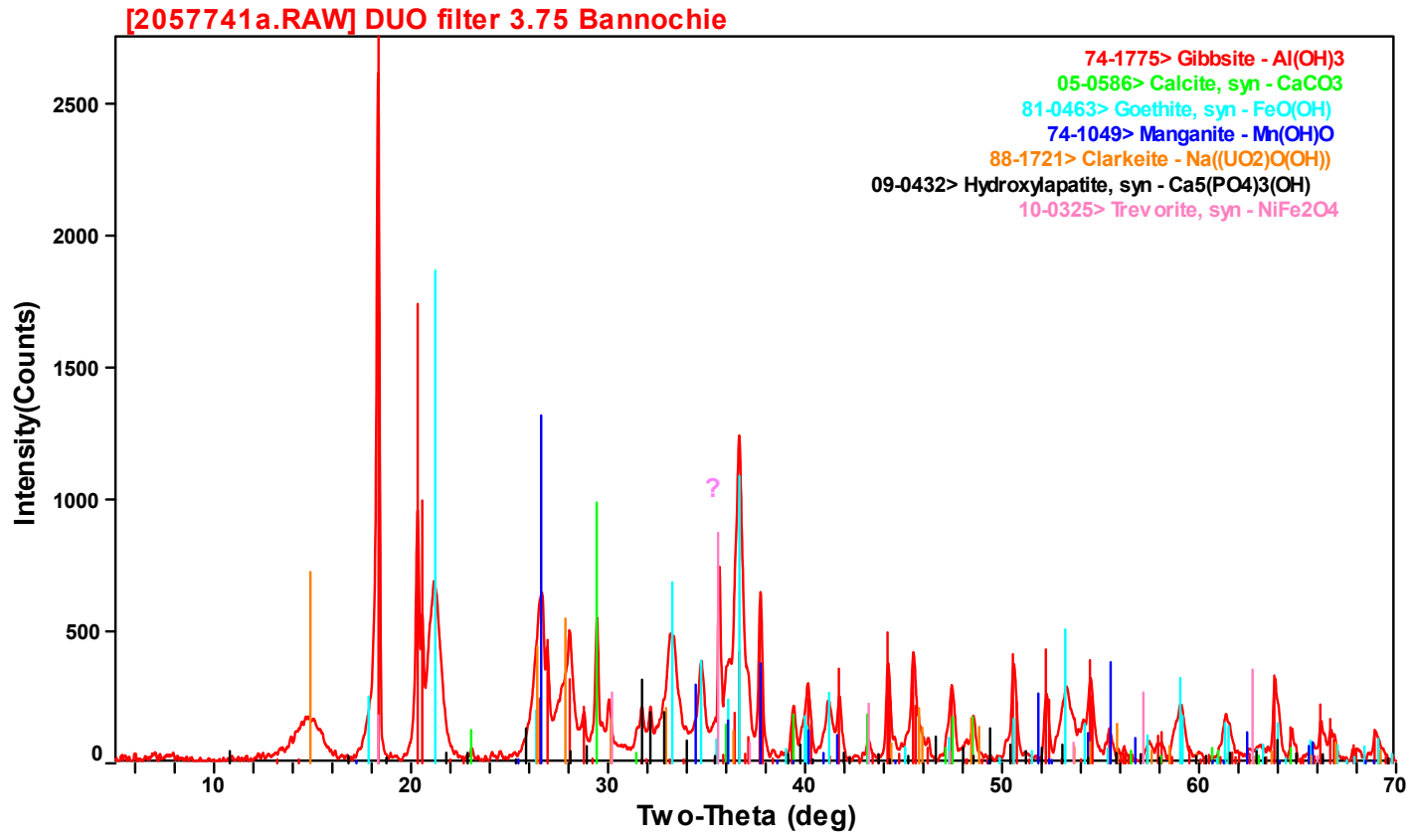

Figure 2-2. XRD Spectra of the Batch 3.75 Uranium SB2 Simulant

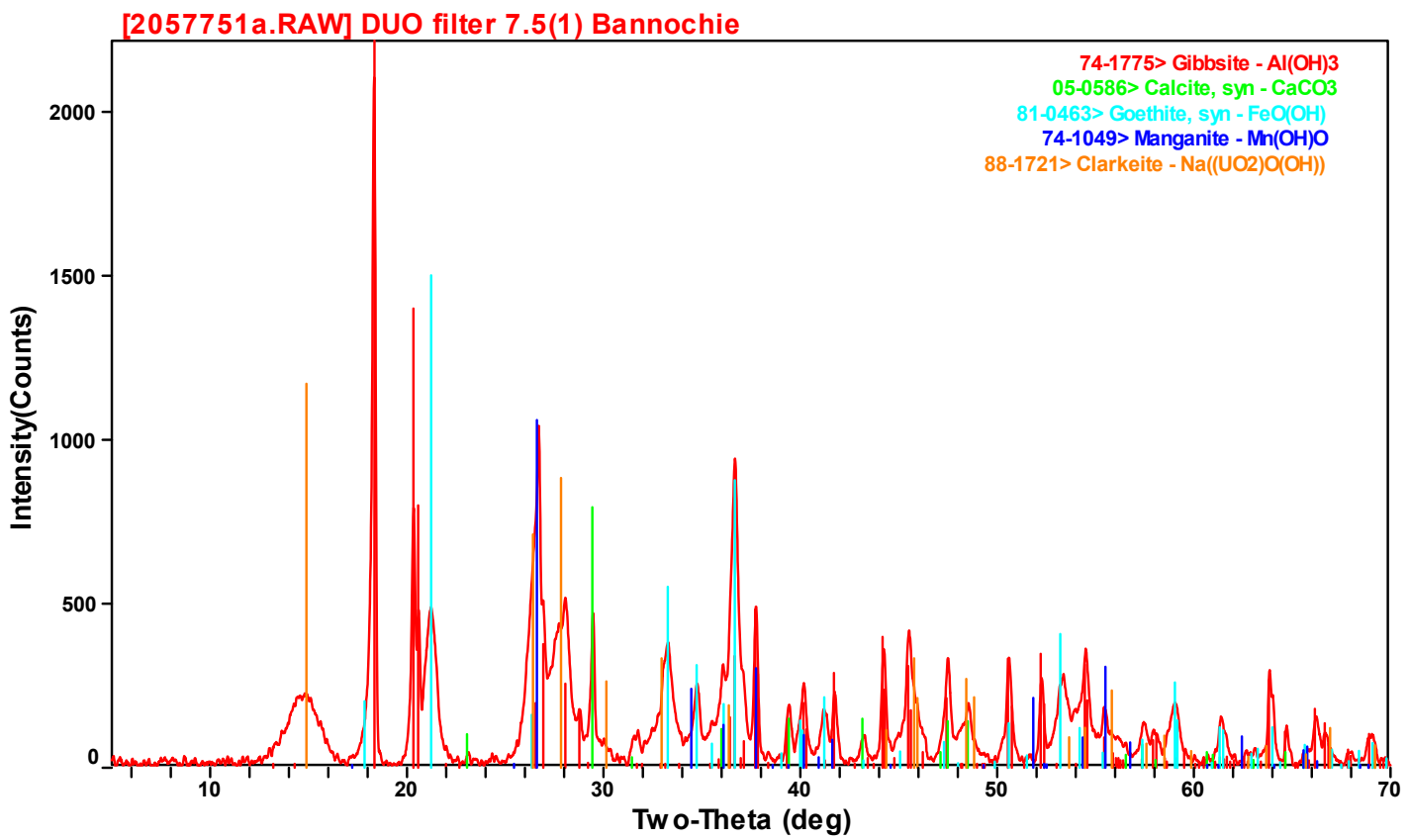

Figure 2-3. XRD Spectra of the Batch 7.5i Uranium SB2 Simulant 


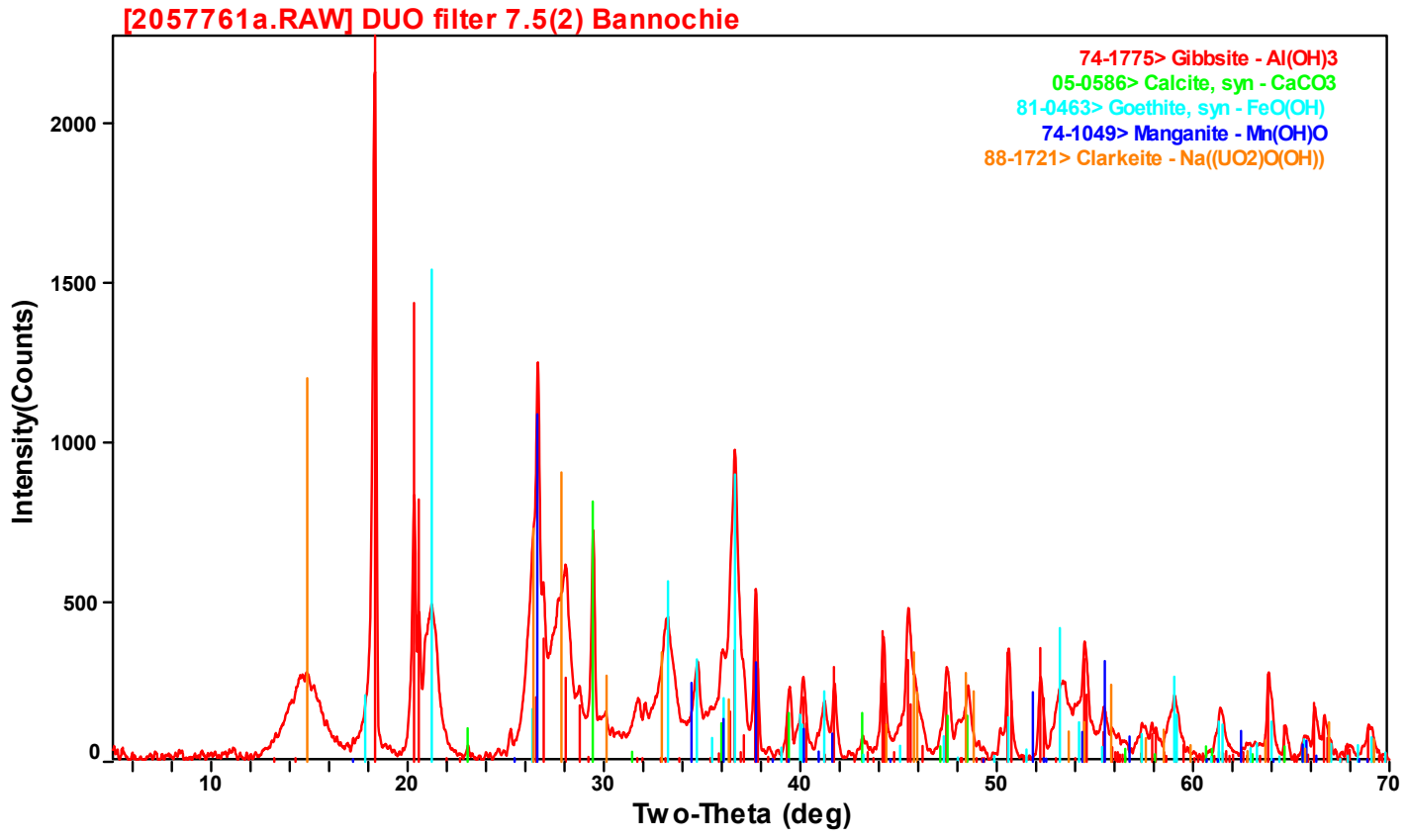

Figure 2-4. XRD Spectra of the Batch 7.5ii Uranium SB2 Simulant

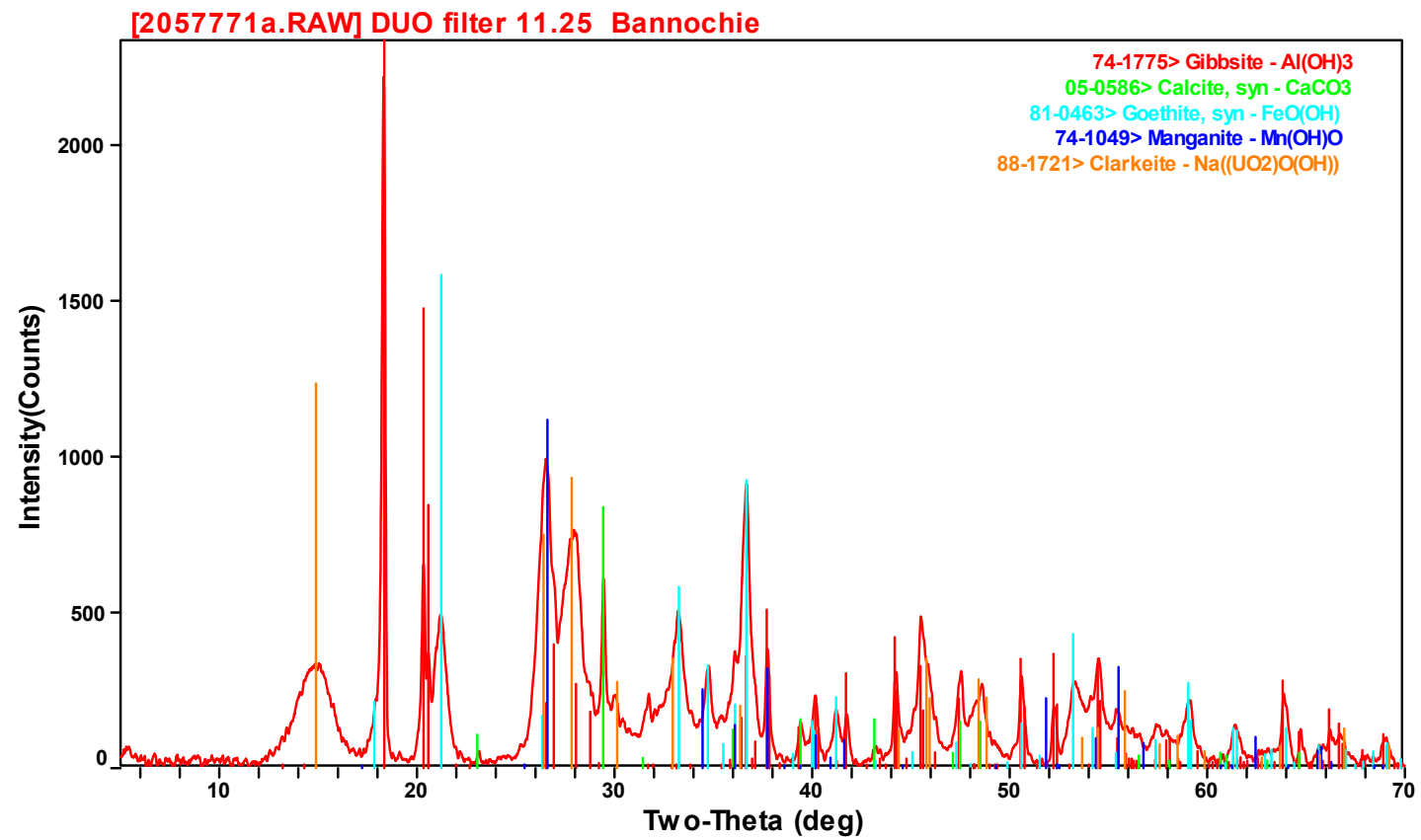

Figure 2-5. XRD Spectra of the Batch 11.25 Uranium SB2 Simulant 


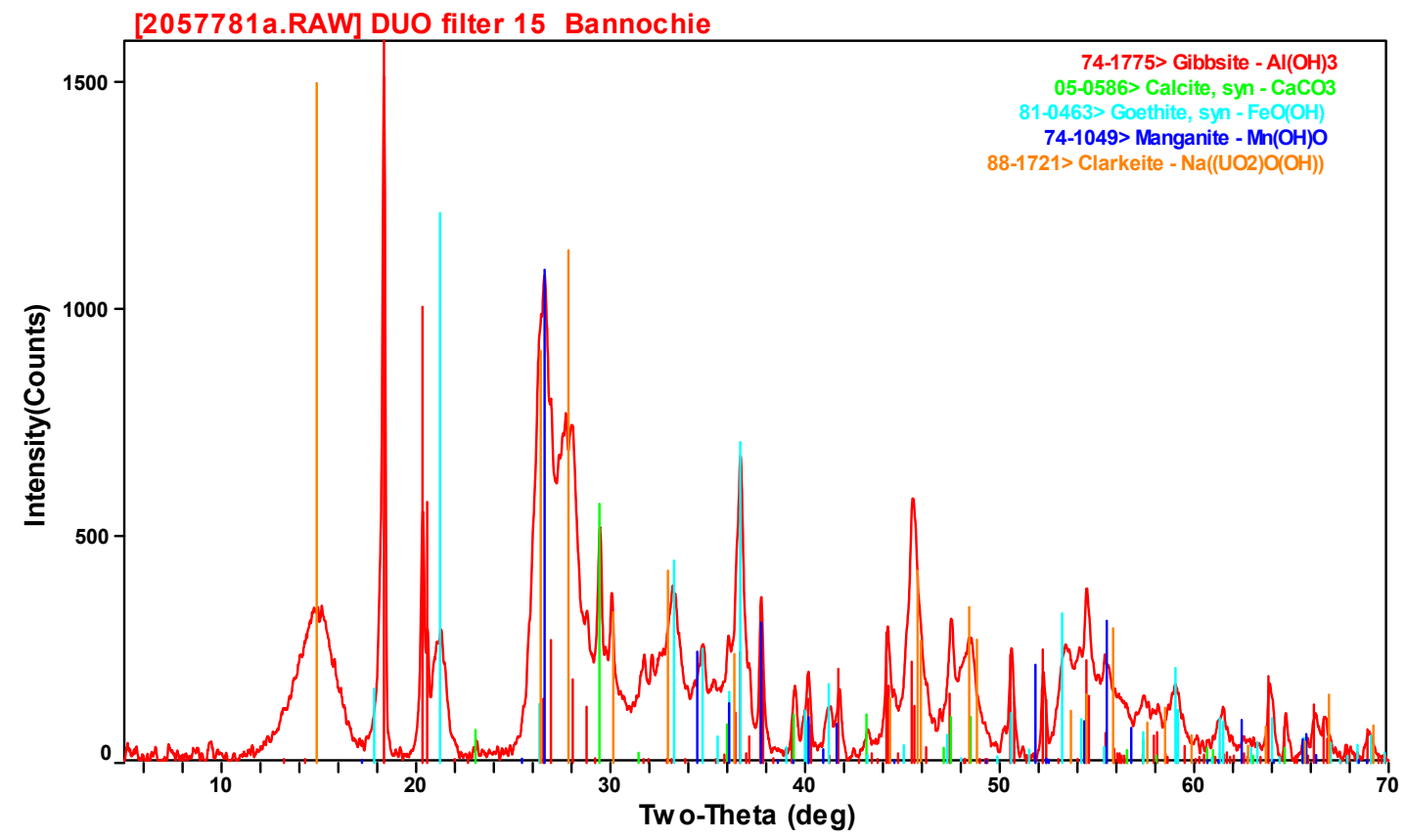

Figure 2-6. XRD Spectra of the Batch 15 Uranium SB2 Simulant

In preparation for SRAT acid calculations, each sludge batch was titrated to approximately $\mathrm{pH} 4$ with $1.034 \mathrm{M}$ nitric acid and the base equivalents at $\mathrm{pH} 7$ calculated. The titrations were performed with the SRNL Shielded Cells protocol using a $20-30$ g sample with $1 \mathrm{~mL}$ additions of acid, mixing for three minutes, followed by a $\mathrm{pH}$ reading. No attempt was made to address the rate of acid addition issues raised in the previous study ${ }^{5}$, since these are being addressed in other ongoing studies. Table 2-10 summarizes the $\mathrm{pH}$ measurements and the titration data measurements for the best two of three titrations. Even when all three replicates for each batch are considered and the overall average taken for all of the batches, the average base equivalents calculates to 0.324 eq/L (Std. Dev. 0.010, \%RSD 3.0). Based upon these measurements, there did not appear to be an acid demand resulting from an increase in the uranium content. For the acid calculations the base equivalents were held constant at $0.325 \mathrm{eq} / \mathrm{L}$ for all the batches. By holding the base equivalents constant in the calculation, changes in the acid demand during the SRAT processing of each sludge would be easier to detect.

Table 2-10. Uranium Sludges pH and Base Equivalents to pH 7

\begin{tabular}{ccc}
\hline Batch No. & pH & $\begin{array}{c}\text { Average Base Equivalents, Eq/L } \\
\text { (Std. Dev., \%RSD) }\end{array}$ \\
\hline 0 & 11.92 & $0.327(0.004,1.3)$ \\
3.75 & 11.93 & $0.325(0.001,0.3)$ \\
$7.5 \mathrm{i}$ & 11.83 & $0.328(0.002,0.7)$ \\
$7.5 \mathrm{ii}$ & 11.79 & $*$ \\
11.25 & 11.77 & $0.320(\mathrm{NA}, \mathrm{NA})$ \\
15 & 11.93 & $0.324(0.004,1.2)$ \\
Average & NA & $\mathbf{0 . 3 2 5}(\mathbf{0 . 0 0 3}, \mathbf{0 . 9})$ \\
\hline
\end{tabular}

* $\mathrm{pH}$ probe calibration issues invalidated data 


\subsubsection{Physical Characterization}

Table 2-11 summarizes the wt \% solids determinations made on each simulant batch. Elemental compositions were obtained for samples calcined at $1100^{\circ} \mathrm{C}$. The overall average total solids were 21.5 wt \% (Std. Dev. 0.5\%, \%RSD 2.4), insoluble solids were 17.8 wt \% (Std. Dev. 0.4\%, \%RSD 2.2), soluble solids were $3.71 \mathrm{wt} \%$ (Std. Dev. 0.14\%, \%RSD 3.7), and calcined solids were $16.4 \mathrm{wt} \%$ (Std. Dev. $0.3 \%, \%$ RSD 1.9), indicating reasonably good consistency of preparation batch to batch. The spread in the two replicate $7.5 \mathrm{wt} \% \mathrm{U}$ batches gives some indication of the degree of repeatability when conducting sludge preparations of this kind.

Table 2-11. SRAT Cycle Feeds Wt \% Solids (Std. Dev., \%RSD)

\begin{tabular}{ccccc}
\hline Batch No. & Total Solids & Insoluble Solids & Soluble Solids & Calcined $\dagger$ \\
\hline 0 & 22.2 & 18.2 & 3.96 & 16.4 \\
& $(0.03,0.15)$ & $(0.04,0.21)$ & $(0.01,0.21)$ & $(0.00,0.01)$ \\
3.75 & 21.5 & 17.8 & 3.72 & 16.1 \\
& $(0.04,0.21)$ & $(0.06,0.35)$ & $(0.02,0.49)$ & $(0.03,0.21)$ \\
$7.5 \mathrm{i}$ & 21.1 & 17.4 & 3.69 & 16.0 \\
& $(0.03,0.16)$ & $(0.06,0.36)$ & $(0.05,1.4)$ & $(0.02,0.12)$ \\
$7.5 \mathrm{ii}$ & 21.8 & 18.1 & 3.71 & 16.7 \\
& $(0.01,0.05)$ & $(0.04,0.22)$ & $(0.03,0.87)$ & $(0.04,0.22)$ \\
11.25 & 21.7 & 18.0 & 3.69 & 16.8 \\
& $(0.06,0.29)$ & $(0.05,0.28)$ & $(0.03,0.78)$ & $(0.02,0.12)$ \\
15 & 20.6 & 17.1 & 3.51 & 16.2 \\
& $(0.14,0.70)$ & $(0.11,0.63)$ & $(0.04,1.1)$ & $(0.08,0.50)$ \\
\hline
\end{tabular}

$\dagger 1100^{\circ} \mathrm{C}$

Samples of each slurry were submitted for particle size analysis. The diluent requirement was higher than the amount of slurry which could be dedicated for this purpose, so the diluent was derived from Clemson Environmental Technology Laboratory (CETL) SB2 untrimmed simulant supernate. It was felt that this material would be more representative of the actual supernate than would deionized water. The data collected is summarized in Table 2-12 and the full Microtrac volume and number distribution diagrams are provided in Appendix C. The mean diameter of the volume distribution (mv) varies from $14-29 \mu \mathrm{m}$, while the mean diameter of the number distribution $(\mathrm{mn})$ varies from $1.9-3.9 \mu \mathrm{m}$. The last column of Table 2-12 indicates that $95 \%$ of the particles measured have a mean diameter less than the value provided. Unfortunately, there is no particle size data on recent tank samples due to activity limits on samples that can be run outside of the SRNL Shielded Cells. Future addition of a particle size capability to the Shielded Cells would provide a mechanism for comparing future sludge samples, and the development of correlations between particle size characteristics and processing behaviors. 
WSRC-TR-2004-00206

Revision 0

Table 2-12. SRAT Cycle Feeds Particle Size Analyses (values in $\mathbf{m} \mu$ )

\begin{tabular}{cccc}
\hline Batch No. & mv & mn & $\mathbf{9 5}^{\text {th }}$ Percentile \\
\hline 0 & 29 & 2.3 & $\leq 5.6$ \\
3.75 & 24 & 2.8 & $\leq 6.6$ \\
$7.5 \mathrm{i}$ & 16 & 3.9 & $\leq 7.4$ \\
$7.5 \mathrm{ii}$ & 14 & 3.6 & $\leq 6.4$ \\
11.25 & 17 & 3.4 & $\leq 6.6$ \\
15 & 26 & 1.9 & $\leq 5.0$ \\
\hline
\end{tabular}

The supernate and slurry densities for each batch were measured and are summarized in Table 2-13. For the purposes of the acid calculation an average supernate and slurry density were used since the measured densities varied by only $\pm 0.01 \mathrm{~g} / \mathrm{mL}$, or less, from the average. The slurry density would be expected to increase with the $U$ concentration, but the observations indicate the $\mathrm{wt} \%$ total solids probably had an influence.

Table 2-13. Measured Slurry and Supernate Densities $(\mathrm{g} / \mathrm{mL})$

\begin{tabular}{ccc}
\hline Batch No. & Slurry Density & Supernate Density \\
\hline 0 & $1.19_{2}$ & $1.04_{3}$ \\
3.75 & $1.19_{1}$ & $1.04_{2}$ \\
$7.5 \mathrm{i}$ & $1.19_{0}$ & $1.03_{9}$ \\
$7.5 \mathrm{ii}$ & $1.18_{5}$ & $1.04_{3}$ \\
11.25 & $1.18_{5}$ & $1.04_{0}$ \\
15 & $1.17_{2}$ & $1.03_{2}$ \\
Average & $\mathbf{1 . 1 8}$ & $\mathbf{1 . 0 4}$ \\
\hline
\end{tabular}

\subsubsection{Rheological Properties of SRAT Feeds}

Rheological measurements were planned for all six sludge simulants and for all six SRAT products. There was an interest in assessing the rheological stability of the six starting sludges, since the ages of the sludges ranged from a few days to several weeks. This was driven by the need to spread the SRAT cycles over a period of about five weeks. Each sludge slurry had two preliminary rheological characterizations, one on January 22 and one of January 26 of 2004.

There were two preliminary findings. First, there was an indication that four to five of the six sludges might still be thickening over the course of the two measurements. Second, the Batch 7.5ii sludge was found to be significantly more viscous than the other five sludges, including the $7.5 \mathrm{i}$ sludge. This could not be attributed to any significant difference in the wt \% total solids content. Therefore, a fresh sample was taken from the 7.5ii sludge. This was rechecked on February 3, 2004. The preliminary finding was confirmed at this time. The reason for the difference between the two Batch 7.5 sludge rheograms has not been identified.

Based on the preliminary findings, the rheological plan was updated to recheck the sludge rheology on the day before each SRAT cycle. The SRAT product measurements were made on the day following completion of the SRAT cycle. This ensured a valid comparison between the sludges and their corresponding SRAT products that was free of potential aging issues. After reviewing all of the data, it appeared that any effect of aging on the sludge rheology was minor. Once this was clearly demonstrated, the pre-run sludge testing was discontinued. When the Batch 3.75 sludge was run through a second SRAT cycle, the sludge rheology was not re-measured the day before the run (this also 
increased the mass of material available for the SRAT test). An additional pair of SRAT product measurements was made, however, when the Batch 3.75 sludge test was repeated.

This revised rheological plan led to the following data set of sludge rheological measurements. Two preliminary and two pre-run measurements were made on each sludge slurry. Readers interested in the individual flow curve results should consult Appendix E. The Batch 7.5ii sludge slurry also had the two follow-up characterizations described above. There were a total of 26 flow curve measurements made on the six sludge slurries. The six pairs of pre-run measurements were made on the days shown in Table $2-14$.

Table 2-14. Dates of Pre-Run Sludge Rheology Measurements

\begin{tabular}{cc}
\hline Batch No. & Date Measured \\
\hline 0 & $2 / 17 / 2004$ \\
3.75 & $2 / 23 / 2004$ \\
$7.5 \mathrm{i}$ & $2 / 9 / 2004$ \\
$7.5 \mathrm{ii}$ & $3 / 3 / 2004$ \\
11.25 & $2 / 26 / 2004$ \\
15 & $3 / 1 / 2004$ \\
\hline
\end{tabular}

The six starting sludges, when well mixed, can all be classified as thin homogeneous slurries (with the possible exception of Batch 7.5ii which was thick and homogeneous). This was somewhat unexpected, since the DU study sludges were prepared with higher wt \% total solids $(21-22 \%)$ than the USC and CETL SB2 simulants (16 wt \% and $19.4 \mathrm{wt} \%$ total solids, respectively), and these previous simulants were fairly viscous. The six new sludges also exhibited varying degrees of thixotropy, or the tendency to thin with time under shear. This was more pronounced than in other recent sludge simulants. It may partially have been a consequence of the low apparent viscosities. The six samples when vigorously shaken showed a negligible tendency to entrain air. Figure 2-7 compares the rheology of CETL sludge used in the $2003 \mathrm{U}^{\text {testing }}{ }^{5}$ (Batch 0 case) with the Batch 0 sludge prepared for this study. The 7/29/03 CETL sludge measurement was also made on the RV20/M5 instrument that was used for the current study. It was chosen over measurements on the cold rheometers at the ACTL to eliminate any questions related to rheometer characteristics. 
WSRC-TR-2004-00206

Revision 0

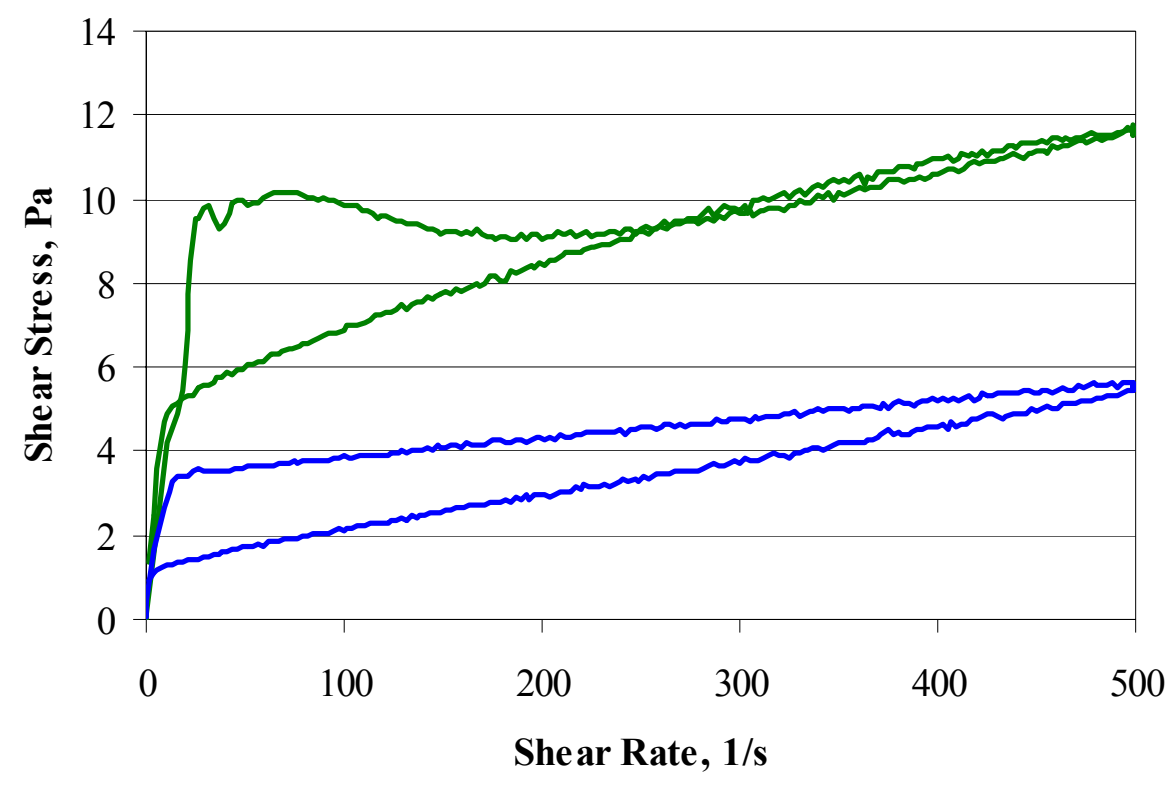

RV20, 7/29/03 (CETL) - RV20, 2/17/04*

Figure 2-7. Comparison of the Rheology of CETL and SRNL SB2 Simulants without Uranium

The CETL sludge 5 was $17.2 \mathrm{wt} \%$ total solids while the SRNL sludge (marked with an *) was $22.2 \mathrm{wt} \%$ total solids. The SRNL sludge was only $20-50 \%$ as viscous as the CETL sludge over most of the shear rate range tested. The SRNL Batch 0 sludge was considered an improvement over the CETL sludge, because the flow curve did not have the distinctive hump in the up ramp portion.

Typical up and down ramp flow curves for the six starting sludges are shown in the two composite graphs, Figure 2-8 and Figure 2-9. In every instance the down flow curve was below the up flow curve. The Batch 7.5ii slurry stands out on both figures as being thicker than the other five slurries. 


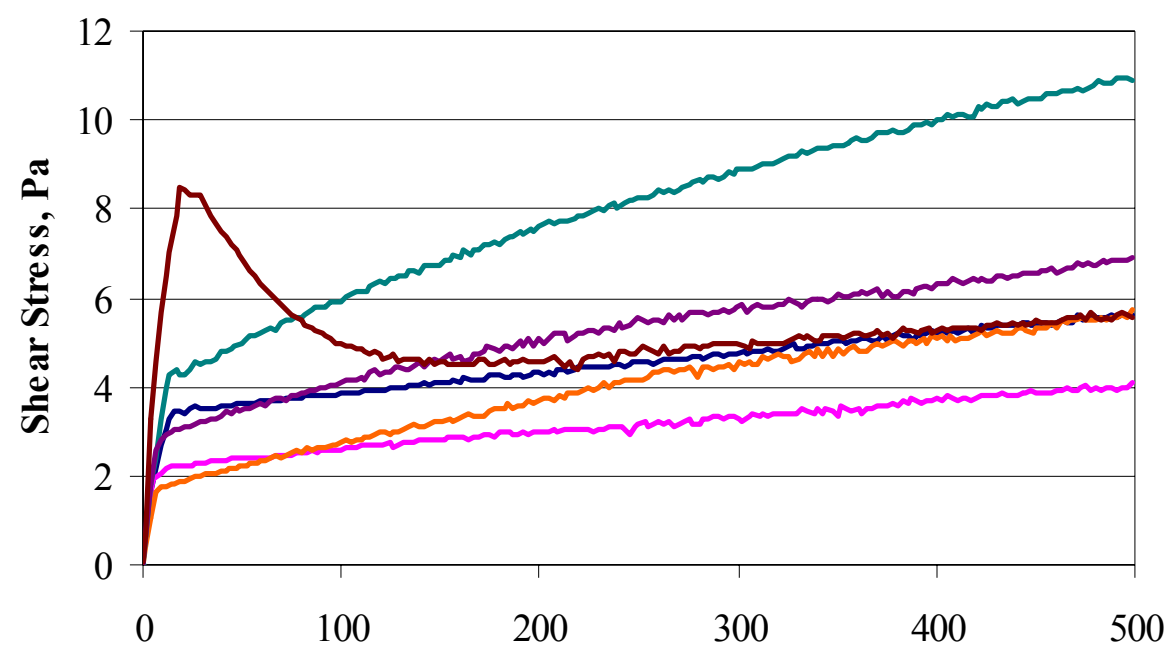

She ar Rate, $1 / \mathrm{s}$

$-0-3.75-7.5 \mathrm{i}-7.5 \mathrm{ii}-11.25-15$

Figure 2-8. Typical Up Ramp Flow Curves for the Starting Sludges

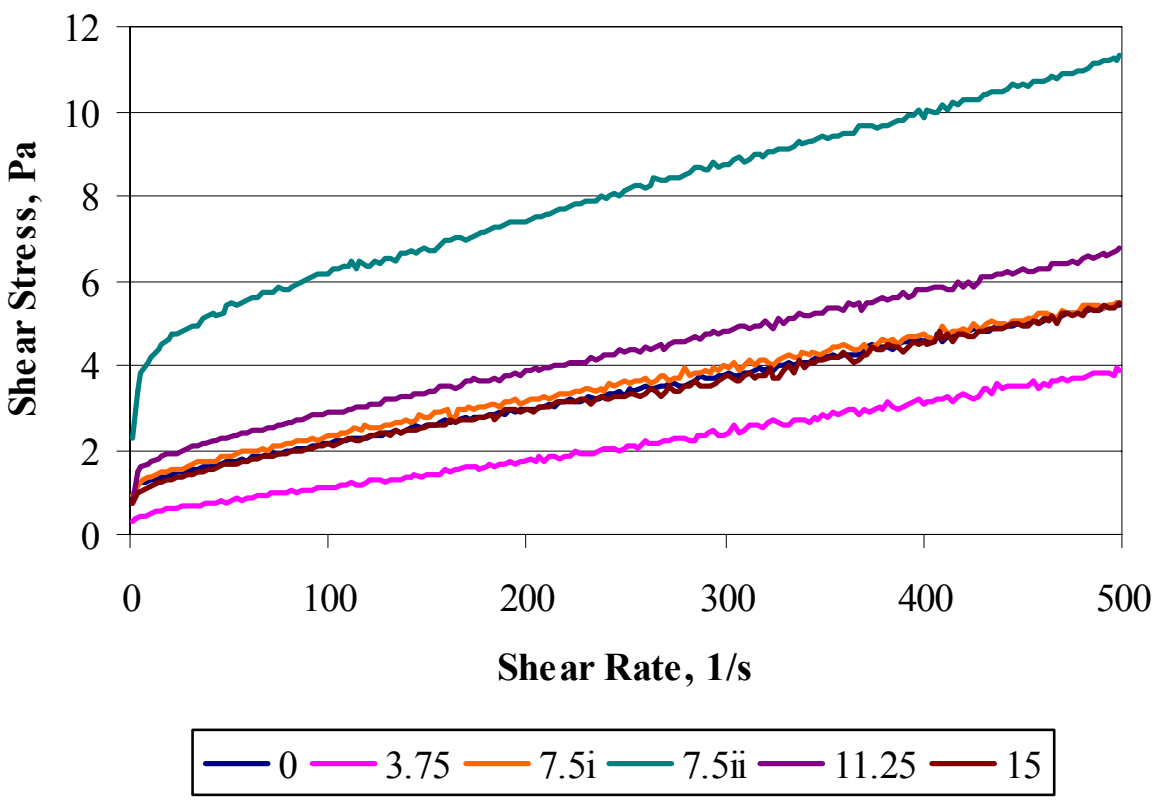

Figure 2-9. Typical Down Ramp Flow Curves for the Starting Sludges

The Batch 0 and 15 down ramp flow curves are nearly superimposed. The Batch 15 sludge was considered rheologically problematic. This slurry exhibited a large hump in the up ramp flow curve (in all replicates), similar to that seen in the CETL SB2 simulant. The hump occurred between 0/s and $200 / \mathrm{s}$. The size of this hump varied from measurement to measurement, but seemed larger in the later pre-run measurements than in the earlier preliminary measurements. The humps limited Bingham plastic model fits to the region from $200 / \mathrm{s}$ to $500 / \mathrm{s}$ for this sludge, i.e. the region far from zero shear rate. Since the Bingham plastic yield stress is the extrapolation of the linear rheology data to zero shear rate, the 
hump increased the range of shear rates that had to be extrapolated through to reach zero shear rate. More discussion on the hump in the sludge rheograms is given near the end of the section. The other up ramp flow curves and all down ramp flow curves were fitted to the shear rate data between $30 / \mathrm{s}$ to $500 / \mathrm{s}$.

There was a second issue with this set of sludge simulants. Fitting data to the Bingham plastic model was only satisfactory in providing a relative ranking of the sludges due to the thixotropic nature of the samples (Bingham plastic time-independent model being fit to time-dependent data). A relative ranking appears permissible, since the samples were handled and analyzed in a consistent manner. The DWPF operating region for sludges was taken to be a yield stress between 25 and $100 \mathrm{dynes} / \mathrm{cm}^{2}$ and a consistency of 4-12 $\mathrm{cP}^{4}$. Table 2-15 below summarizes average regression results for the six starting sludges.

Table 2-15. Sludge Bingham Plastic Model Parameters

\begin{tabular}{cccccc}
\hline Batch No. & $\begin{array}{c}\text { Yield Stress } \\
\text { Up ramp } \\
\text { Dynes/cm }\end{array}$ & $\begin{array}{c}\text { Yield Stress } \\
\text { Down ramp } \\
\text { Dynes/cm }\end{array}$ & $\begin{array}{c}\text { Consistency } \\
\text { Up ramp } \\
\text { cP }\end{array}$ & $\begin{array}{c}\text { Consistency } \\
\text { Down ramp } \\
\text { cP }\end{array}$ & $\begin{array}{c}\text { Wt \% } \\
\text { Total } \\
\text { Solids }\end{array}$ \\
\hline 0 & 33 & 17 & 5.9 & 8.7 & 22.2 \\
3.75 & 22 & 7.0 & 4.7 & 7.3 & 21.5 \\
$7.5 \mathrm{i}$ & 20 & 1.4 & 8.0 & 8.5 & 21.1 \\
$7.5 \mathrm{ii}$ & 53 & 45 & 14 & 15 & 21.8 \\
11.25 & 33 & 22 & 8.3 & 9.7 & 21.7 \\
15 & 37 & 13 & 3.9 & 8.2 & 20.6 \\
\hline DWPF Operating Region & $25-100$ & $25-100$ & $4-12$ & $4-12$ & $13-19$ \\
\hline
\end{tabular}

Two trends are evident in the rheological data. The yield stress fell and the consistency increased between the up ramp and the down ramp in all six cases. There were no exceptions to either trend. The yield stress fell by roughly $8-24$ dynes $/ \mathrm{cm}^{2}$, and the consistency increased by roughly $1-4 \mathrm{cP}$. No trend due to the depleted uranium content was detected. The slurry rheological data tended to lie near the lower end of the range (least viscous boundary) of the operating region for DWPF. See comments in Section 3.2 .5 concerning why trend exists.

Figure 2-10 shows the individual yield stresses calculated from the up ramp portions of the flow curves for five sludges (excluding the Batch 15 case which had the hump in the up ramp curve). The notation (-a) indicates the initial pre-run measurement and (-b) indicates the replicate pre-run measurement. Dates for the pre-run measurements are given in Table 2-14 above. Full flow curves are given in Appendix D, and regression analyses are given in Appendix E. 
WSRC-TR-2004-00206

Revision 0

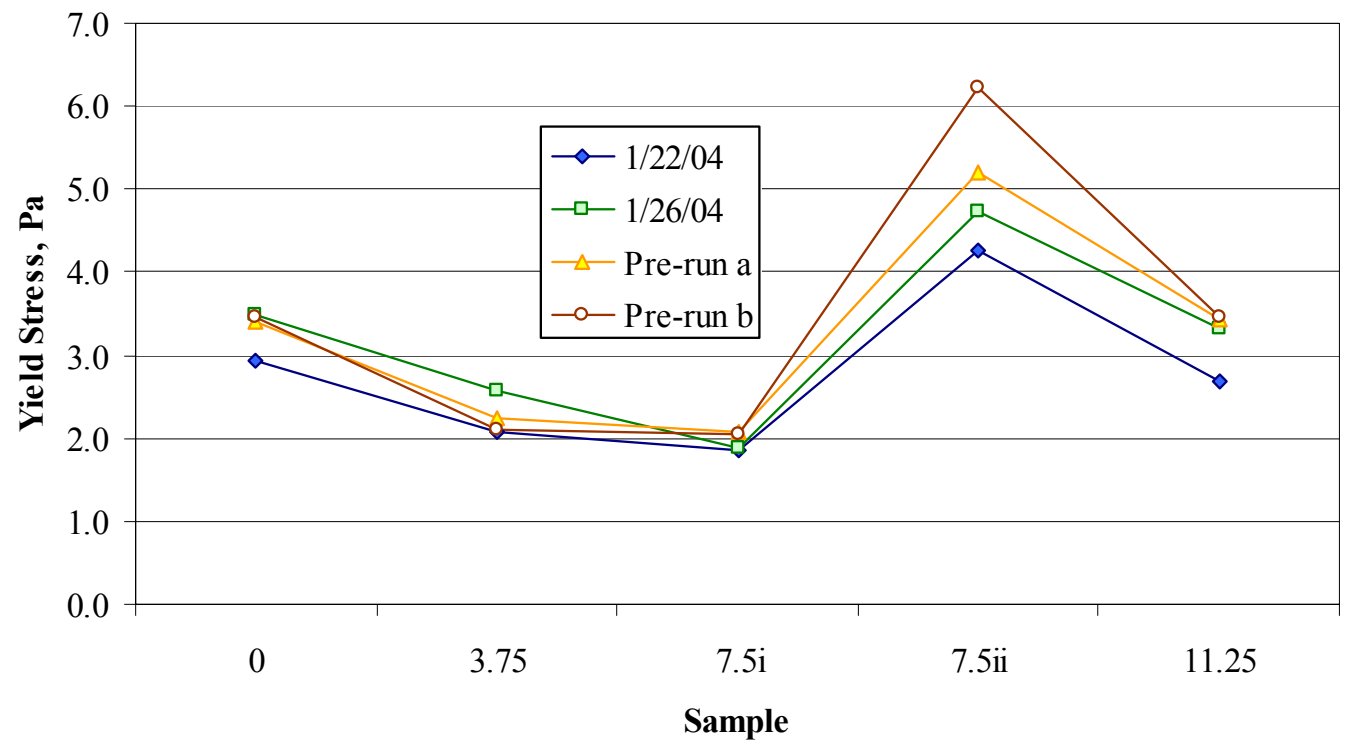

Figure 2-10. Variation of Sludge Yield Stress - Up Ramp Basis

The two re-sample results for the Batch 7.5ii sludge are not shown. Those yield stresses were 5.19 and 5.27 $\mathrm{Pa}$ and fell within the range of Batch 7.5ii results given on the graph. The yield stresses for the other three $U$ levels fall in between those of the two Batch 7.5 preparations. This leads to the conclusion that small variations in sludge simulant preparation are as significant as any effect due to the presence of the uranium.

The significance of the hump in the Batch 15 sludge simulant was investigated at the time of the pre-run measurements. Following the primary flow curve measurement, the sample was kept in the concentric cylinder sensor and subjected to a second flow curve measurement, i.e. re-ramped through the shear rate region containing the hump. This measurement was only made from $0 / \mathrm{s}$ to $200 / \mathrm{s}$ with two minute ramps up and down and a six second hold. The re-ramp test was done on both replicates of the pre-run sludge simulant sample. Results are shown in Figure 2-11. 
WSRC-TR-2004-00206

Revision 0

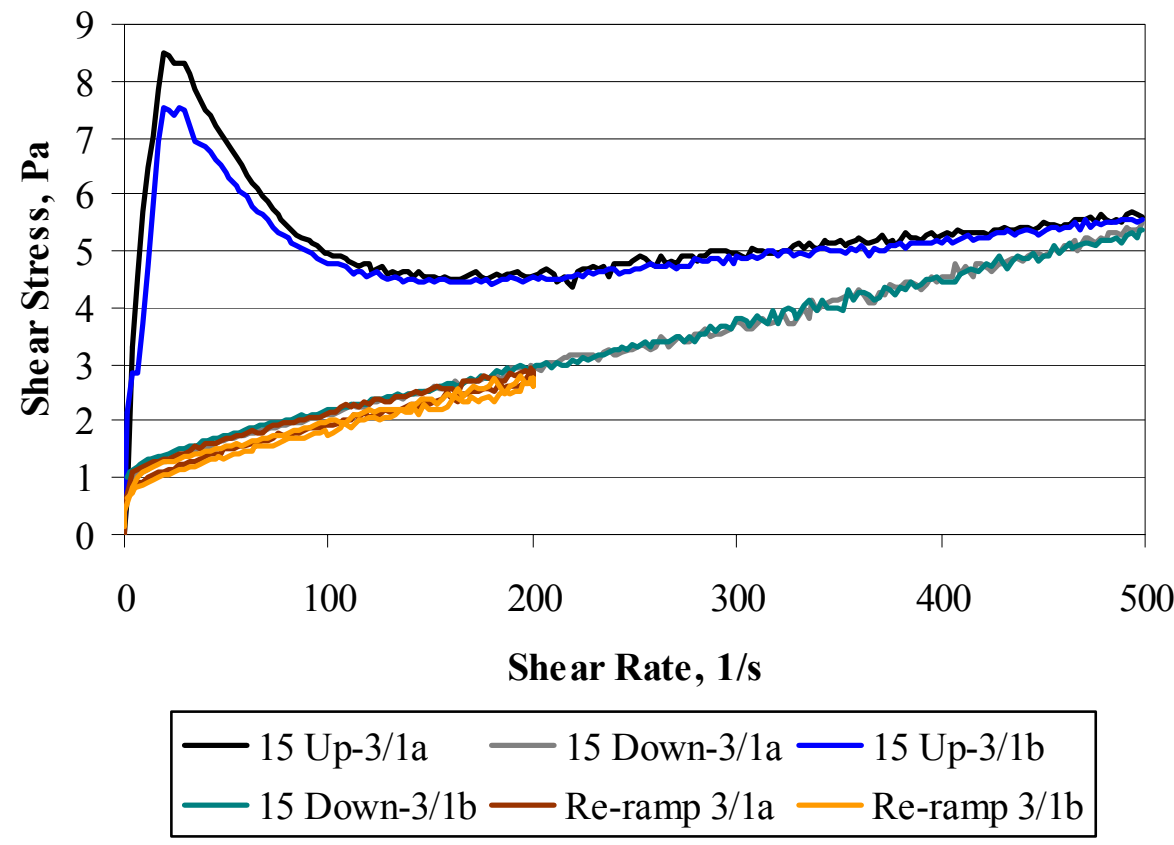

Figure 2-11. Transient Nature of Up Ramp Flow Curve Hump for Batch 15 Sludge

Noteworthy observations on Figure 2-11 include the excellent reproducibility obtained on the two primary replicates $(-a$ and $-b)$, the significant thinning between the up ramp and the down ramp portions of the primary measurements $(0 / \mathrm{s}-500 / \mathrm{s}-0 / \mathrm{s})$, the complete lack of a hump in the re-ramp curves, and the negligible subsequent thinning indicated in the re-ramp curves. This data indicate that the hump is a transient phenomenon. This observation, and a similar observation on a SRAT product with a hump, led to the decision to neglect the hump portion of the flow curve in calculating the Bingham plastic yield stress and consistency. 


\subsection{SRAT CYCLE}

\subsection{Approach}

\subsubsection{Equipment Set-Up}

The vessel used with each of the six prepared sludge batches was a glass cylinder approximately 6.75 inches in height and 3.5-3.825 inches in diameter. The vessel has a capacity of approximately one liter. The top of the vessel consisted of a glass lid fitted with a set of ports. These ports were for the installations of supporting equipment, e.g. the primary off-gas line from the SRAT condenser, the air purge inlet, the formic and nitric acid addition lines, and for antifoam addition. The vessel setup was similar to that used in the SRNL Shielded Cells SB3 Qualification (refer to Figure 3-1) except no GC (and hence no manometer) or repeater pipette for antifoam additions was used. Agitation was provided with an overhead mounted drive with variable speed control.

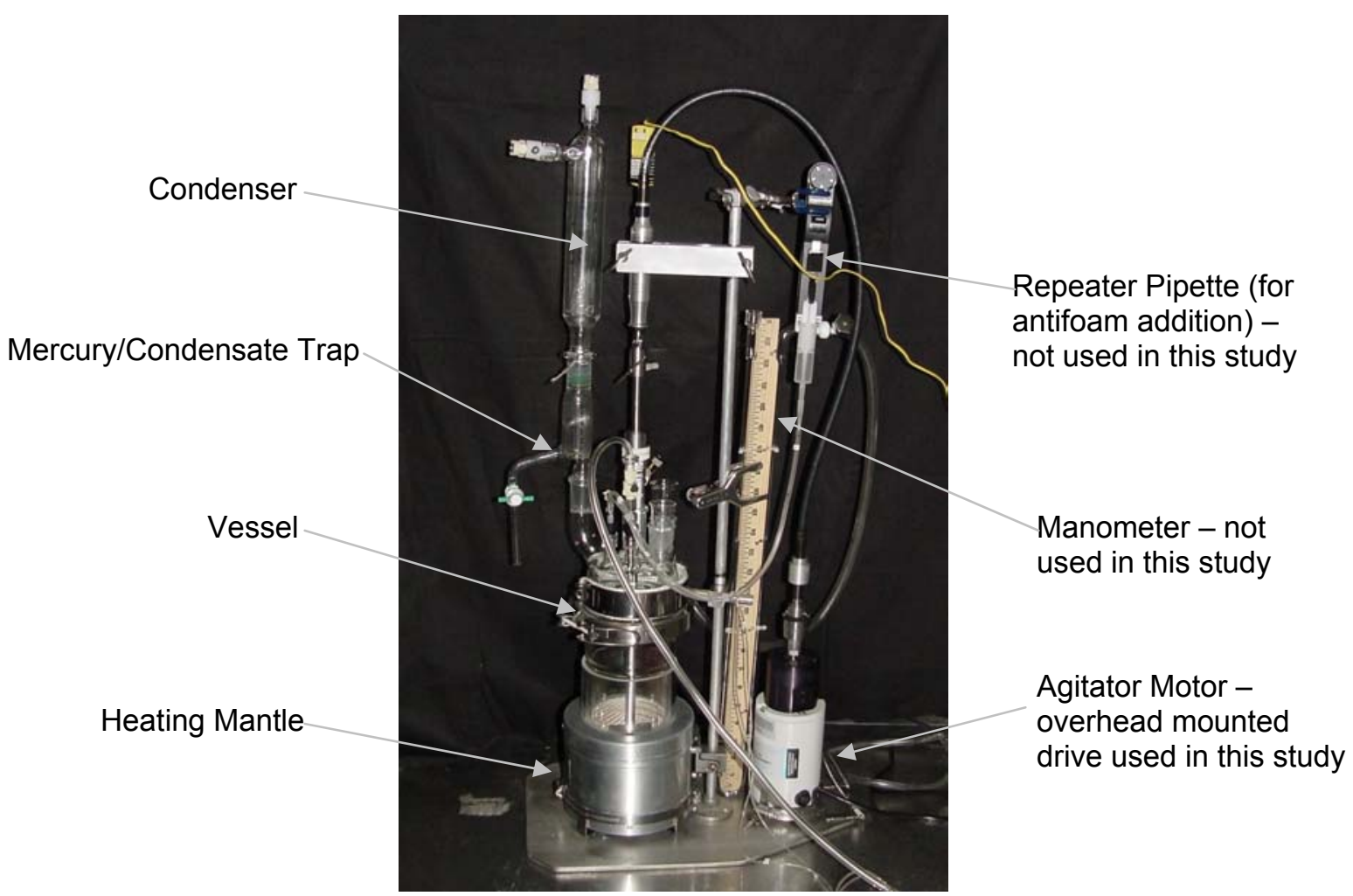

Figure 3-1. Photograph of the 1-L SRAT vessel similar to that used in this study.

Acid additions for the $7.5 \mathrm{i}$ wt \% U sludge run were done with a MasterFlex cartridge pump as used in the Shielded Cells. Separate lines were used for nitric acid and formic acid but with the same cartridge head. A variable speed controller was used to adjust the flow rate to achieve the equivalent of two gallons/min in DWPF. For all remaining SRAT cycles, a piston style acid addition pump (TOA Limited, Japan) was used for nitric acid and formic acid addition as used at ACTL. This allowed for digital selection of the scaled addition rate and total volumes of nitric and formic acids in each run. 
A SRAT condenser/decanter was calibrated and used in each of the experiments. The condenser was cooled using chilled water at between $8-20^{\circ} \mathrm{C}$. The temperature was initially set at $10^{\circ} \mathrm{C}$ and lowered during the first run in an attempt to increase the boil-up condensate collection rate, but it may have had the opposite impact in that it resulted in more condensate condensing prior to reaching the decanter. In later runs the condenser was held at 15 or $20^{\circ} \mathrm{C}$ in order to achieve the desired DWPF-scaled boil-up rate.

The heat source to the SRAT was an electric heating mantle that covered the lower two inches $(180 \mathrm{~mL})$ of the vessel. The mantle was controlled by a multipurpose DigiTrol II controller connected to the SRAT thermocouple. This controller was used for both temperature set-point control, e.g. during acid addition at $93^{\circ} \mathrm{C}$, and for boil-up rate control, i.e., achieving the bench-scale equivalent to a DWPF-scale $5000 \mathrm{lbs} / \mathrm{hr}$ boil-up rate.

The agitator had variable speeds and the impeller consisted of three blades perpendicular to the shaft. The agitator was driven by a variable speed mixer (Lightnin Lab Master, Model L1U10F). The speed was adjusted until a small vortex was visible on the surface of the slurry which corresponded to $260 \mathrm{rpm}$. The same rate of agitation was used in all the experiments.

Air was supplied for purging the SRAT vessel from the Building 773-A house line. The flow rate was adjusted and controlled with a MKS flow controller. A DWPF scaled SRAT purge flow was used during the test. The DWPF purge rate is $230 \mathrm{cfm}^{\mathrm{c}}$. Off-gas measurements with a GC were not made for these experimental SRAT cycles.

\subsubsection{Acid Calculations for the SRAT Cycles}

Analytical data from Section 2.0, along with data presented in this section, were entered into the Immobilization Technology Section's (ITS) acid addition calculation spreadsheet ${ }^{7}$. The total acid requirements were determined for each experiment. These were then divided into nitric acid and formic acid using projected anion reaction outcomes and an iron in glass redox target of $0.20 \mathrm{Fe}^{2+} / \Sigma \mathrm{Fe}$.

Samples of the nitric and formic acids used in these experiments were checked with a DMA-4500 density meter at Aiken County Technical Laboratory (ACTL). The nitric acid was $10.28 \mathrm{M} \mathrm{(49.6 \textrm {wt } \% )}$ and the specific gravity at this molarity and $20^{\circ} \mathrm{C}$ is 1.307 . The analysis for formic acid was $23.59 \mathrm{M}$ $(90.1 \mathrm{wt} \%)$ with a specific gravity at this molarity and $20^{\circ} \mathrm{C}$ of 1.205 .

The recommended target for acid in these SRAT cycles was $130 \%$ of the calculated stoichiometric requirement. This recommendation was based upon the results of simulant work conducted during the processing issues study (Refer to Figure $3-2)^{8}$. While DWPF has used between $125-180 \%$ of the calculated stoichiometric requirement, we wanted to avoid the low SRAT product $\mathrm{pH}$ 's found in the previous $\mathrm{U}$ work ${ }^{5}$ and the corresponding solubilization of sludge metal oxides that accompanies the low $\mathrm{pH}$. Figure 3-2 indicates that at $130 \%$ of the calculated acid stoichiometric requirement the product $\mathrm{pH}$ will be around 5.3. The redox equation developed and recommended for SB3 processing instead of the F-3N equation was used. The new redox equation was described in WSRC-TR-2003-00126 (C. M. Jantzen et al. $)^{9}$.

${ }^{\mathrm{c}} \mathrm{DWPF}$ purge rates are referenced to $70^{\circ} \mathrm{F}$ and 1 atmosphere. 
WSRC-TR-2004-00206

Revision 0

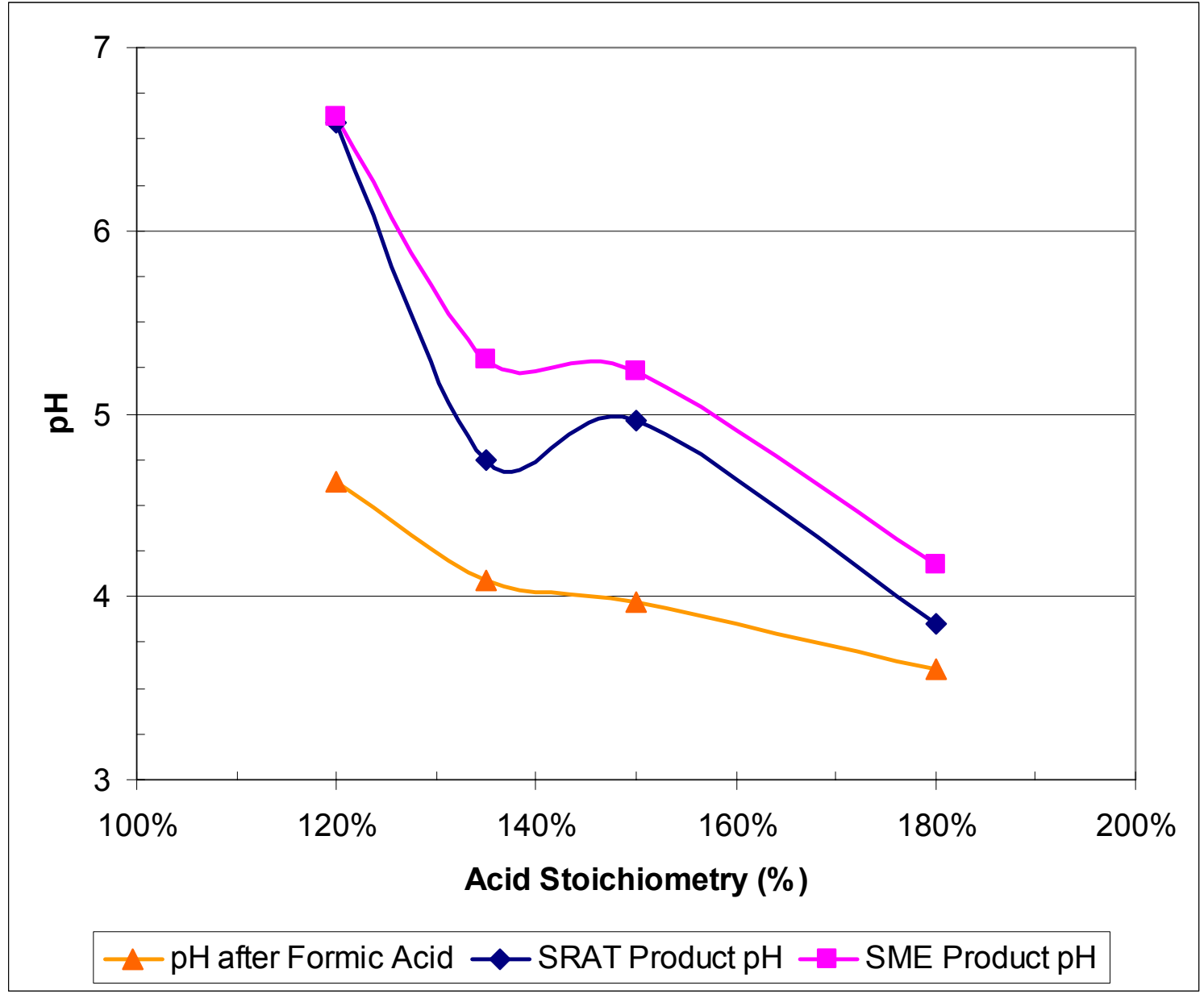

Figure 3-2. Impact of Acid Stoichiometry on pH observed during the SB2 Processing Issues Study

Table 3-1 summarizes the inputs to and output from the SRAT cycle acid calculations performed for these experiments. 
WSRC-TR-2004-00206

Revision 0

Table 3-1. Summary of Inputs and Outputs for Uranium Sludge SRAT Cycle Acid Calculations

\begin{tabular}{|c|c|c|c|c|c|c|}
\hline & $\mathbf{0}$ & 3.75 & $7.5 \mathbf{i}$ & 7.5ii & 11.25 & 15 \\
\hline Nitrite $(\mathrm{mg} / \mathrm{kg}) \dagger$ & 8390 & 8390 & 8390 & 8390 & 8390 & 8390 \\
\hline Nitrate $(\mathrm{mg} / \mathrm{kg}) \dagger$ & 3690 & 3690 & 3690 & 3690 & 3690 & 3690 \\
\hline Oxalate $(\mathrm{mg} / \mathrm{kg})$ & 0 & 0 & 0 & 0 & 0 & 0 \\
\hline TIC $(\mathrm{mg} / \mathrm{kg})$ & 1852 & 1740 & 1640 & 1638 & 1557 & 1375 \\
\hline Base Equivalents (M) $\dagger$ & 0.325 & 0.325 & 0.325 & 0.325 & 0.325 & 0.325 \\
\hline $\mathrm{Mn}$ (wt $\%$ in dried solids) & 2.29 & 2.08 & 2.00 & 2.10 & 1.91 & 1.78 \\
\hline $\mathrm{Hg}$ (wt \% in dried solids) $\dagger$ & 0.195 & 0.195 & 0.195 & 0.195 & 0.195 & 0.195 \\
\hline Total Solids (wt \%) & 22.2 & 21.5 & 21.1 & 21.8 & 21.7 & 20.6 \\
\hline Sludge Density $(\mathrm{kg} / \mathrm{L})$ & 1.185 & 1.185 & 1.185 & 1.185 & 1.185 & 1.185 \\
\hline $\begin{array}{l}\text { Assumed Formate } \\
\text { Destruction }\end{array}$ & $26 \%$ & $26 \%$ & $26 \%$ & $26 \%$ & $26 \%$ & $26 \%$ \\
\hline $\begin{array}{l}\text { Assumed Nitrite } \\
\text { Destruction }\end{array}$ & $100 \%$ & $100 \%$ & $100 \%$ & $100 \%$ & $100 \%$ & $100 \%$ \\
\hline $\begin{array}{l}\text { Assumed Nitrite to Nitrate } \\
\text { Conversion }\end{array}$ & $12 \%$ & $12 \%$ & $12 \%$ & $12 \%$ & $12 \%$ & $12 \%$ \\
\hline Receipt Mass (g) & 300 & 300 & 300 & 300 & 300 & 300 \\
\hline Acid Stoichiometry & $130 \%$ & $130 \%$ & $130 \%$ & $130 \%$ & $130 \%$ & $130 \%$ \\
\hline Redox Target $(\mathrm{Fe} 2+/ \Sigma \mathrm{Fe})$ & 0.20 & 0.20 & 0.20 & 0.20 & 0.20 & 0.20 \\
\hline $\begin{array}{l}\text { Moles of Acid/Liter of } \\
\text { Slurry }\end{array}$ & 1.19 & 1.14 & 1.11 & 1.12 & 1.09 & 1.03 \\
\hline
\end{tabular}

$\dagger$ †alue held constant for all sludge calculations

\subsubsection{Description of SRAT Cycles}

Each SRAT cycle was completed per a run plan ${ }^{10,11,12,13,14,15}$. The same run plan was used for both Batch 3.75 SRAT cycles. A summary of processing parameters and acid addition amounts is presented in Table 3-2. A summary of the SRAT cycle is given below:

The DWPF antifoam addition strategy was used:

- Add $200 \mathrm{ppm}$ antifoam to vessel prior to acid addition (at around $50^{\circ} \mathrm{C}$ ).

- Add 100 ppm antifoam after nitric acid addition (prior to formic acid addition).

- Add 500 ppm antifoam after formic acid addition (prior to boiling).

- Add 100 ppm additional antifoam every 8 hours, as necessary, until the vessel temperature is below $50^{\circ} \mathrm{C}^{\mathrm{d}}$.

The slurry was heated to $93^{\circ} \mathrm{C}$.

Nitric acid was added.

Formic acid was added.

The slurry was heated to boiling.

Water was removed - the water removed was equivalent to the volume of acid and flush water additions.

The slurry was refluxed for 12 hours.

At the completion of the SRAT cycle, the slurry was sampled and characterized. During the Batch 0 SRAT cycle, the nitric acid target of $5.02 \mathrm{~mL}$ was missed. The actual amount of nitric acid addition was $6.56 \mathrm{~mL}$. To compensate, the amount of formic acid added was reduced to $10.90 \mathrm{~mL}$ from the original target of $11.57 \mathrm{~mL}$. The resulting redox target was then calculated as 0.149 , rather than the desired 0.200 .

\footnotetext{
${ }^{d}$ No additional antifoam was employed in any of these SRAT cycles since there were no signs of foaming during
} reflux. 
WSRC-TR-2004-00206

Revision 0

Table 3-2. DWPF and SRNL Scale SRAT Processing Parameters and Target Acid Addition Amounts

\begin{tabular}{|c|c|c|c|c|c|c|c|}
\hline Parameter & DWPF Scale & $\begin{array}{c}\text { Batch } \\
0 \dagger\end{array}$ & $\begin{array}{c}\text { Batch } \\
3.75 \\
\end{array}$ & $\begin{array}{c}\text { Batch } \\
7.5 \mathrm{i} \\
\end{array}$ & $\begin{array}{c}\text { Batch } \\
7.5 \mathrm{ii}\end{array}$ & $\begin{array}{l}\text { Batch } \\
11.25 \\
\end{array}$ & $\begin{array}{c}\text { Batch } \\
15 \\
\end{array}$ \\
\hline SRAT Contents & 6,000 gal & $300 \mathrm{~g}$ & $300 \mathrm{~g}$ & $300 \mathrm{~g}$ & $300 \mathrm{~g}$ & $300 \mathrm{~g}$ & $300 \mathrm{~g}$ \\
\hline Gas Purge Rate & $\begin{array}{c}230 \\
\text { scfm }\end{array}$ & $\begin{array}{l}78.5 \\
\mathrm{sccm}\end{array}$ & $\begin{array}{c}78.5 \\
\mathrm{sccm}\end{array}$ & $\begin{array}{r}78.5 \\
\mathrm{sccm}\end{array}$ & $\begin{array}{l}78.5 \\
\mathrm{sccm}\end{array}$ & $\begin{array}{r}78.5 \\
\mathrm{sccm}\end{array}$ & $\begin{array}{l}78.5 \\
\mathrm{sccm}\end{array}$ \\
\hline Acid Addition Rate & $\begin{array}{c}2 \\
\mathrm{gal} / \mathrm{min}\end{array}$ & $\begin{array}{c}0.09 \\
\mathrm{~mL} / \mathrm{min}\end{array}$ & $\begin{array}{c}0.09 \\
\mathrm{~mL} / \mathrm{min}\end{array}$ & $\begin{array}{c}0.09 \\
\mathrm{~mL} / \mathrm{min}\end{array}$ & $\begin{array}{c}0.09 \\
\mathrm{~mL} / \mathrm{min}\end{array}$ & $\begin{array}{c}0.09 \\
\mathrm{~mL} / \mathrm{min}\end{array}$ & $\begin{array}{c}0.09 \\
\mathrm{~mL} / \mathrm{min}\end{array}$ \\
\hline Boil Up Rate & $5,000 \mathrm{lbs} / \mathrm{hr}$ & $28 \mathrm{~g} / \mathrm{hr}$ & $28 \mathrm{~g} / \mathrm{hr}$ & $28 \mathrm{~g} / \mathrm{hr}$ & $28 \mathrm{~g} / \mathrm{hr}$ & $28 \mathrm{~g} / \mathrm{hr}$ & $28 \mathrm{~g} / \mathrm{hr}$ \\
\hline Acid Stoichiometry & $130 \%$ & $130 \%$ & $130 \%$ & $130 \%$ & $130 \%$ & $130 \%$ & $130 \%$ \\
\hline Nitric Acid & 94 - 110 gal & $5.02 \mathrm{~mL}$ & $4.86 \mathrm{~mL}$ & $4.70 \mathrm{~mL}$ & $4.74 \mathrm{~mL}$ & $4.60 \mathrm{~mL}$ & $4.30 \mathrm{~mL}$ \\
\hline Formic Acid & $221-254$ gal & $11.57 \mathrm{~mL}$ & $11.12 \mathrm{~mL}$ & $10.82 \mathrm{~mL}$ & $10.92 \mathrm{~mL}$ & $10.61 \mathrm{~mL}$ & $10.07 \mathrm{~mL}$ \\
\hline
\end{tabular}

$\dagger$ Actual acid additions differed from target, see text for details.

\subsection{Results}

The SRAT cycles were completed per the run plans with the exception of Batch 0 already noted in Section 3.1. Two portions of feed from Batch 3.75 were processed due to uncertainties in the recorded starting and product volumes, which could not be readily explained. No additional antifoam was necessary after the initiation of boiling, since there was no foaming observed in the systems. At the end of the cycle, nitrite was destroyed from all the feeds. Some of the feeds showed more of a tendency to swell upon being brought to boiling than others perhaps due to air entrainment.

\subsubsection{Product Characterization}

The following tables summarize the solids, density, $\mathrm{pH}$, anion, and elemental composition of the SRAT cycle products produced from the uranium containing SB2 slurries. There are no clear trends in this data with respect to uranium content. Comparison of the two nominal $7.5 \mathrm{wt} \%$ sludges gives some estimate of the variability in synthesizing consistent sludges, while the nominal $3.75 \mathrm{wt} \%$ sludge data represents two SRAT cycles with the same starting material.

Uncertainty surrounding the final volume of SRAT product for Batch 3.75-1 which could not be explained necessitated the second processing of this batch. The second Batch 3.75 SRAT cycle had the lower final SRAT product $\mathrm{pH}$ that was expected based on the first SRAT cycle.

The low supernate densities measured for Batches $0,3.75-1$ and 15 are suspect. It is more likely that the $1.06-1.07 \mathrm{~g} / \mathrm{mL}$ values measured for the other sludge batches are correct for SB2 simulants. The average value of $1.063 \mathrm{~g} / \mathrm{mL}$ was used for supernate conversion of elemental data to $\mathrm{mg} / \mathrm{kg}$ slurry as shown in Table 3-8. 
WSRC-TR-2004-00206

Revision 0

Table 3-3. Weight Percent Solids, Density, and Final pH of the SRAT Cycle Products (Std. Dev. and \%RSD)

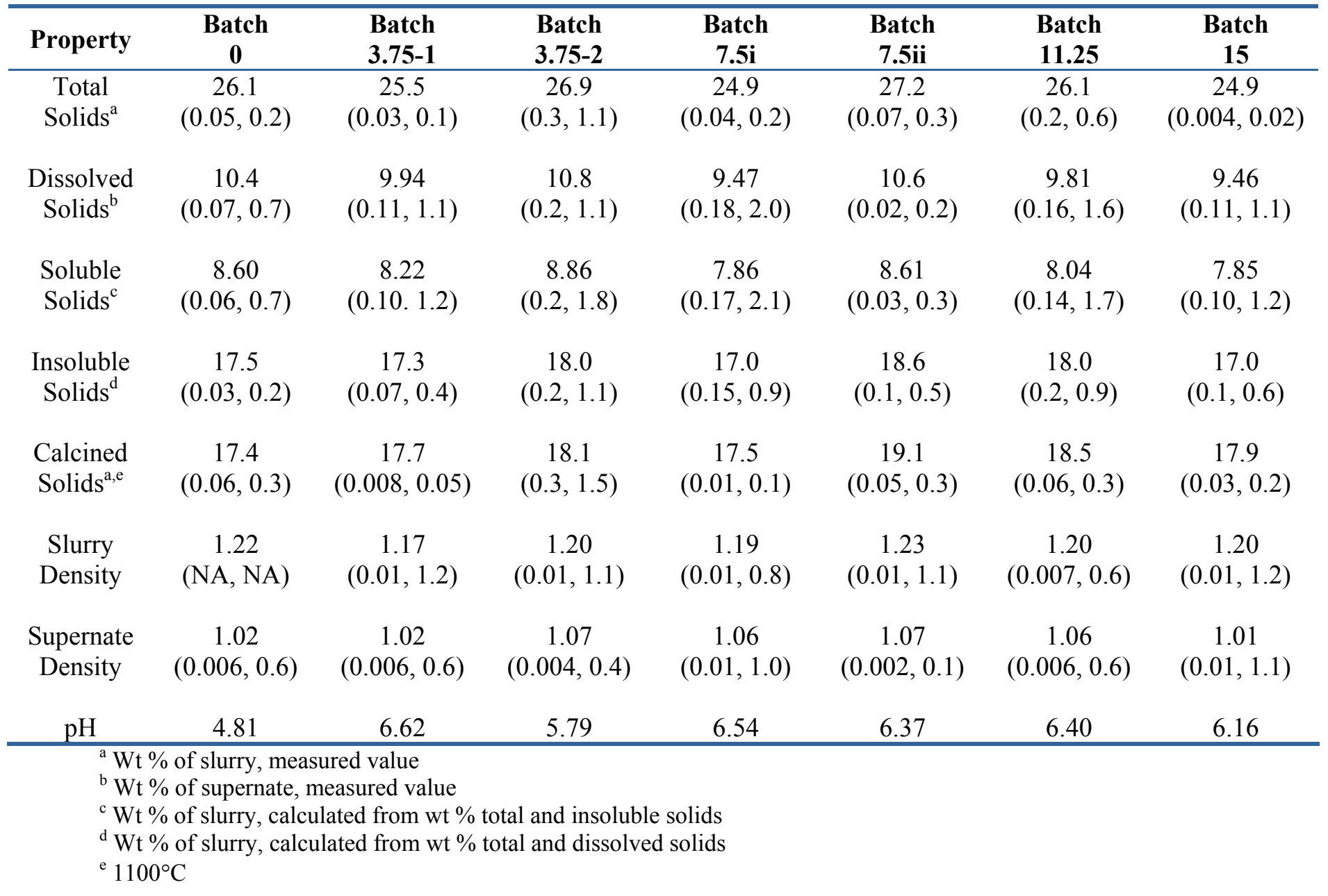

\subsubsection{Nitrite and Formate Destruction}

Anion measurements were made on each of the SRAT products at the end of dewater and on the final SRAT product. Table 3-4 summarizes this data at the completion of the dewater phase of the SRAT cycle. As can be seen by a comparison with the data in Table 2-8, average starting nitrite concentration of $8380 \mathrm{mg} / \mathrm{kg}$ of slurry, most of the nitrite was destroyed prior to the start of reflux. The nitrite value measured here can be subject to considerable variability depending upon the amount of time expended to

Table 3-4. Measured Ion Chromatography Anions in the Post Dewater SRAT Material (mg/kg slurry)

\begin{tabular}{cccccccc}
\hline \multirow{2}{*}{ Anion } & Batch & Batch & Batch & Batch & Batch & Batch & Batch \\
& $\mathbf{0}$ & $\mathbf{3 . 7 5 - 1}$ & $\mathbf{3 . 7 5 - 2}$ & $\mathbf{7 . 5 i}$ & $\mathbf{7 . 5 i i}$ & $\mathbf{1 1 . 2 5}$ & $\mathbf{1 5}$ \\
\hline Formate & 32,300 & 26,600 & 29,100 & 32,400 & 29,000 & 27,200 & 31,100 \\
Nitrate & 28,000 & 17,800 & 18,600 & 22,800 & 19,000 & 18,600 & 19,500 \\
\multirow{2}{*}{ Nitrite } & $<84$ & 2170 & $<63$ & 870 & 706 & 279 & 769 \\
Sulfate & 1380 & 1470 & 1060 & 1460 & 1490 & 1430 & 1390 \\
\hline
\end{tabular}


reach the point of reflux as a result of acid addition time variations and more significantly, the time to achieve the desired boil-up rate. These factors may be reflected in the significant variation observed between the two Batch 3.75 SRAT cycle values ( $2170 \mathrm{vs.}<63 \mathrm{mg} / \mathrm{kg}$ slurry).

Table 3-5 summarizes the anion data collected on the final SRAT product. All measurements were made in triplicate and averaged. At the completion of each of the SRAT cycles, the nitrite ion concentration was below detection.

Table 3-5. Measured Ion Chromatography Anions in the SRAT Products (mg/kg slurry)

\begin{tabular}{cccccccc}
\hline \multirow{2}{*}{ Anion } & Batch & Batch & Batch & Batch & Batch & Batch & Batch \\
& $\mathbf{0}$ & $\mathbf{3 . 7 5 - 1}$ & $\mathbf{3 . 7 5 - 2}$ & $\mathbf{7 . 5 i}$ & $\mathbf{7 . 5 i i}$ & $\mathbf{1 1 . 2 5}$ & $\mathbf{1 5}$ \\
\hline Formate & 30,200 & 27,400 & 30,900 & 33,600 & 30,000 & 28,300 & 28,400 \\
& $(1100,3.7)$ & $(1640,6.0)$ & $(2210,7.2)$ & $(4070,12)$ & $(1940,6.5)$ & $(3400,12)$ & $(2870,10)$ \\
\multirow{2}{*}{ Nitrate } & 28,800 & 21,700 & 22,500 & 26,000 & 23,300 & 21,500 & 22,100 \\
& $(764,2.6)$ & $(1360,6.3)$ & $(1410,6.3)$ & $(3350,13)$ & $(1310,5.6)$ & $(2310,11)$ & $(2100,9.5)$ \\
\multirow{2}{*}{ Nitrite } & $<89$ & $<89$ & $<46$ & $<92$ & $<91$ & $<94$ & $<90$ \\
\multirow{2}{*}{ Sulfate } & 1920 & 1550 & 1180 & 1070 & 1370 & 1540 & 1420 \\
& $(95,5.0)$ & $(17,1.1)$ & $(79,6.7)$ & $(47,4.4)$ & $(75,5.5)$ & $(40,2.6)$ & $(74,5.2)$ \\
\hline
\end{tabular}

Several assumptions for anion destruction/conversion were made for the acid calculation (see Table 3-1). These assumptions involve nitrite to nitrate conversion, nitrite destruction, and formate destruction. Although the assumptions are based on overall processing (SRAT and SME cycles), SRAT cycle destruction/conversion is presented for information in Table 3-6. It should be noted that the Batch 0 SRAT cycle had more nitric acid added than necessary, so the formic acid level was reduced to keep the total moles of acid constant. The Batch $7.5 \mathrm{i}$ results are likely influenced by the high \%RSD for the nitrate and formate data used in the calculation (refer to Table 3-5).

Table 3-6. Calculated SRAT Cycles Nitrite Destruction, Nitrite to Nitrate Conversion, and Percent Formate Destruction

\begin{tabular}{cccccccc}
\hline & Batch & Batch & Batch & Batch & Batch & Batch & Batch \\
& $\mathbf{0}$ & $\mathbf{3 . 7 5 - 1}$ & $\mathbf{3 . 7 5 - 2}$ & $\mathbf{7 . 5 i}$ & $\mathbf{7 . 5 i i}$ & $\mathbf{1 1 . 2 5}$ & $\mathbf{1 5}$ \\
\hline $\begin{array}{c}\text { Nitrite } \\
\text { Destruction }\end{array}$ & $100 \%$ & $100 \%$ & $100 \%$ & $100 \%$ & $100 \%$ & $100 \%$ & $100 \%$ \\
$\begin{array}{c}\text { Nitrite to } \\
\text { Nitrate } \\
\text { Conversion }\end{array}$ & $81 \%$ & $60 \%$ & $67 \%$ & $122 \%$ & $84 \%$ & $70 \%$ & $81 \%$ \\
$\begin{array}{c}\text { Formate } \\
\text { Destruction }\end{array}$ & $9 \%$ & $32 \%$ & $23 \%$ & $15 \%$ & $24 \%$ & $26 \%$ & $22 \%$ \\
\hline
\end{tabular}

\subsubsection{Elemental Composition of SRAT Products}

Table 3-7 and Table 3-8 provide the slurry and supernate elemental compositions, respectively, determined from each processed SRAT batch. When this data is related to the final SRAT product pH's (see Table 3-3) the concentration of soluble $\mathrm{Cu}, \mathrm{Mn}, \mathrm{Ni}$, and $\mathrm{Zn}$ show characteristic dependence on the final $\mathrm{pH}$ (see Figure 3-3 derived from data in Table 3-9). 
WSRC-TR-2004-00206

Revision 0

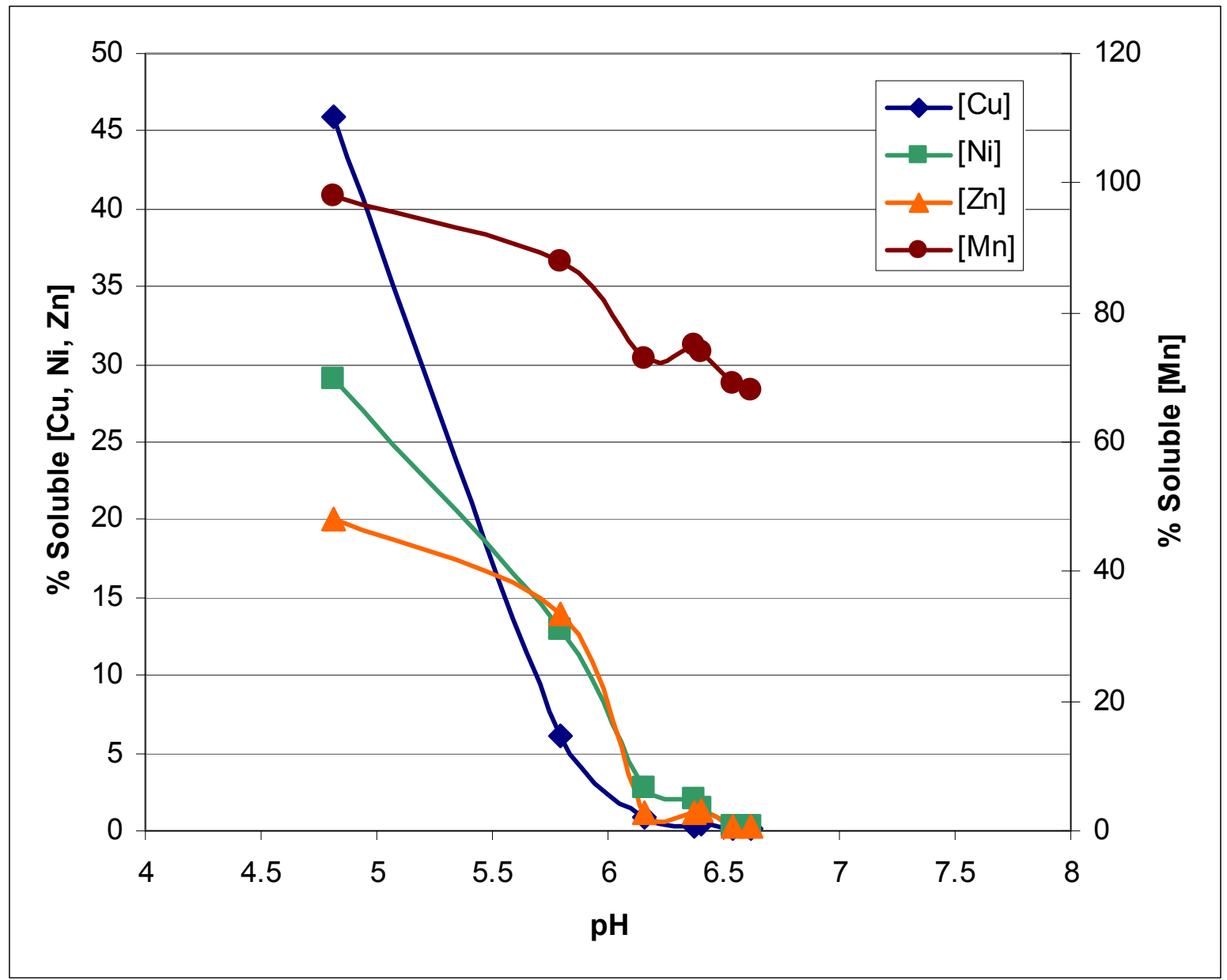

Figure 3-3. Percent Soluble Metal Ion Concentration vs. SRAT Product pH

Unlike these metal ions, the $\mathrm{U}$ was largely insoluble above $\mathrm{pH}$ 6, only in the Batch 3.75 second SRAT cycle product when the $\mathrm{pH}$ was 5.79 , was any appreciable soluble $\mathrm{U}$ measured. 
Table 3-7. Slurry Elements Measured in the SRAT Products in mg/kg slurry (Std. Dev., \%RSD)

\begin{tabular}{|c|c|c|c|c|c|c|c|}
\hline Element & $\begin{array}{c}\text { Batch } \\
\text { 0 }\end{array}$ & $\begin{array}{l}\text { Batch } \\
3.75-1\end{array}$ & $\begin{array}{l}\text { Batch } \\
3.75-2\end{array}$ & $\begin{array}{c}\text { Batch } \\
7.5 i\end{array}$ & $\begin{array}{c}\text { Batch } \\
7.5 \mathrm{ii}\end{array}$ & $\begin{array}{l}\text { Batch } \\
11.25\end{array}$ & $\begin{array}{c}\text { Batch } \\
15\end{array}$ \\
\hline $\mathrm{Al}$ & $\begin{array}{c}26,000 \\
(270,1.0)\end{array}$ & $\begin{array}{c}24,800 \\
(180,0.7)\end{array}$ & $\begin{array}{c}25,500 \\
(360,1.4)\end{array}$ & $\begin{array}{c}22,600 \\
(200,0.9)\end{array}$ & $\begin{array}{c}23,200 \\
(110,0.5)\end{array}$ & $\begin{array}{c}21,300 \\
(390,1.8)\end{array}$ & $\begin{array}{c}18,900 \\
(100,0.5)\end{array}$ \\
\hline $\mathrm{Ca}$ & $\begin{array}{c}4940 \\
(27,0.5)\end{array}$ & $\begin{array}{c}4300 \\
(54,1.3)\end{array}$ & $\begin{array}{c}4970 \\
(48,1.0)\end{array}$ & $\begin{array}{c}4230 \\
(18,0.4)\end{array}$ & $\begin{array}{c}4590 \\
(58,1.3)\end{array}$ & $\begin{array}{c}4180 \\
(70,1.7)\end{array}$ & $\begin{array}{c}3640 \\
(31,0.8)\end{array}$ \\
\hline $\mathrm{Cu}$ & $\begin{array}{c}230 \\
(1.7,0.8)\end{array}$ & $\begin{array}{c}245 \\
(1.8,0.7)\end{array}$ & $\begin{array}{c}233 \\
(3.1,1.3)\end{array}$ & $\begin{array}{c}210 \\
(1.0,0.5)\end{array}$ & $\begin{array}{c}238 \\
(12,5.1)\end{array}$ & $\begin{array}{c}252 \\
(4.3,1.7)\end{array}$ & $\begin{array}{c}251 \\
(4.5,1.8)\end{array}$ \\
\hline $\mathrm{Fe}$ & $\begin{array}{c}50,100 \\
(360,0.7)\end{array}$ & $\begin{array}{c}48,500 \\
(620,1.3)\end{array}$ & $\begin{array}{c}49,000 \\
(730,1.5)\end{array}$ & $\begin{array}{c}43,800 \\
(100,0.2)\end{array}$ & $\begin{array}{c}48,600 \\
(44,0.9)\end{array}$ & $\begin{array}{c}44,800 \\
(520,12)\end{array}$ & $\begin{array}{c}39,200 \\
(100,0.3)\end{array}$ \\
\hline K & $\begin{array}{c}142 \\
(2.0,1.4)\end{array}$ & $\begin{array}{c}147 \\
(2.0,1.4)\end{array}$ & $\begin{array}{c}160 \\
(2.8,1.7)\end{array}$ & $\begin{array}{c}193 \\
(6.6,3.4)\end{array}$ & $\begin{array}{c}192 \\
(2.2,1.2)\end{array}$ & $\begin{array}{c}200 \\
(6.4,3.2)\end{array}$ & $\begin{array}{c}277 \\
(7.8,2.8)\end{array}$ \\
\hline $\mathrm{Mg}$ & $\begin{array}{c}239 \\
(2.7,1.1)\end{array}$ & $\begin{array}{c}230 \\
(2.7,1.2)\end{array}$ & $\begin{array}{c}237 \\
(8.3,3.5)\end{array}$ & $\begin{array}{c}207 \\
(2.0,1.0)\end{array}$ & $\begin{array}{c}203 \\
(4.0,2.0)\end{array}$ & $\begin{array}{c}203 \\
(2.1,1.1)\end{array}$ & $\begin{array}{c}179 \\
(1.8,1.0)\end{array}$ \\
\hline $\mathrm{Mn}$ & $\begin{array}{c}5290 \\
(40,0.8)\end{array}$ & $\begin{array}{c}5050 \\
(45,0.9)\end{array}$ & $\begin{array}{c}5240 \\
(54,1.0)\end{array}$ & $\begin{array}{c}4640 \\
(27,0.6)\end{array}$ & $\begin{array}{c}5130 \\
(29,0.6)\end{array}$ & $\begin{array}{c}4800 \\
(85,1.8)\end{array}$ & $\begin{array}{c}4190 \\
(21,0.5)\end{array}$ \\
\hline $\mathrm{Na}$ & $\begin{array}{c}15,400 \\
(240,1.6)\end{array}$ & $\begin{array}{c}15,300 \\
(220,1.4)\end{array}$ & $\begin{array}{c}16,700 \\
(190,1.1)\end{array}$ & $\begin{array}{c}15,600 \\
(56,0.4)\end{array}$ & $\begin{array}{c}16,700 \\
(61,0.4)\end{array}$ & $\begin{array}{c}16,600 \\
(230,1.4)\end{array}$ & $\begin{array}{c}17,200 \\
(90,0.5)\end{array}$ \\
\hline $\mathrm{Ni}$ & $\begin{array}{c}2460 \\
(56,2.3)\end{array}$ & $\begin{array}{c}2670 \\
(51,1.9)\end{array}$ & $\begin{array}{c}2770 \\
(280,1.0)\end{array}$ & $\begin{array}{c}2510 \\
(10,0.4)\end{array}$ & $\begin{array}{c}2760 \\
(29,1.1)\end{array}$ & $\begin{array}{c}2600 \\
(39,1.5)\end{array}$ & $\begin{array}{c}2220 \\
(10,0.5)\end{array}$ \\
\hline $\mathrm{S}$ & $\begin{array}{c}585 \\
(3.5,0.6)\end{array}$ & $\begin{array}{c}562 \\
(11,1.9)\end{array}$ & $\begin{array}{c}534 \\
(2.8,0.5)\end{array}$ & $\begin{array}{c}538 \\
(12,2.3)\end{array}$ & $\begin{array}{c}514 \\
(2.2,0.4)\end{array}$ & $\begin{array}{c}506 \\
(12,2.4)\end{array}$ & $\begin{array}{c}446 \\
(1.0,0.2)\end{array}$ \\
\hline $\mathrm{Si}$ & $\begin{array}{c}1720 \\
(16,0.9)\end{array}$ & $\begin{array}{c}1640 \\
(9,0.5)\end{array}$ & $\begin{array}{c}1730 \\
(26,1.5)\end{array}$ & $\begin{array}{c}1720 \\
(46,2.7)\end{array}$ & $\begin{array}{c}1640 \\
(16,1.0)\end{array}$ & $\begin{array}{c}1530 \\
(19,1.2)\end{array}$ & $\begin{array}{c}1330 \\
(9.8,0.7)\end{array}$ \\
\hline $\mathrm{U}$ & $<174$ & $\begin{array}{l}7920 \\
(0,0)\end{array}$ & $\begin{array}{c}8510 \\
(28,0.3)\end{array}$ & $\begin{array}{c}15,200 \\
(130,0.9)\end{array}$ & $\begin{array}{c}17,000 \\
(100,0.6)\end{array}$ & $\begin{array}{c}25,300 \\
(570,2.2)\end{array}$ & $\begin{array}{c}32,100 \\
(410,1.3)\end{array}$ \\
\hline $\mathrm{Zn}$ & $\begin{array}{c}585 \\
(3.6,0.6)\end{array}$ & $\begin{array}{c}544 \\
(4.7,0.9)\end{array}$ & $\begin{array}{c}563 \\
(3.8,0.7)\end{array}$ & $\begin{array}{c}517 \\
(4.6,0.9)\end{array}$ & $\begin{array}{c}528 \\
(2.9,0.6)\end{array}$ & $\begin{array}{c}496 \\
(6.0,1.2)\end{array}$ & $\begin{array}{c}435 \\
(3.7,0.9)\end{array}$ \\
\hline $\mathrm{Zr}$ & $\begin{array}{c}886 \\
(22,2.5)\end{array}$ & $\begin{array}{c}772 \\
(18,2.3)\end{array}$ & $\begin{array}{c}837 \\
(15,1.8)\end{array}$ & $\begin{array}{c}782 \\
(14,1.8)\end{array}$ & $\begin{array}{c}821 \\
(13,1.6)\end{array}$ & $\begin{array}{c}747 \\
(37,5.0)\end{array}$ & $\begin{array}{c}678 \\
(37,5.5)\end{array}$ \\
\hline
\end{tabular}


WSRC-TR-2004-00206

Revision 0

Table 3-8. Supernate Elements Measured in the SRAT Products in mg/kg slurry (Std. Dev., \%RSD)

\begin{tabular}{|c|c|c|c|c|c|c|c|}
\hline Element & $\begin{array}{c}\text { Batch } \\
\text { 0 }\end{array}$ & $\begin{array}{l}\text { Batch } \\
\text { 3.75-1 } \\
\end{array}$ & $\begin{array}{l}\text { Batch } \\
\text { 3.75-2 }\end{array}$ & $\begin{array}{c}\text { Batch } \\
7.5 i\end{array}$ & $\begin{array}{c}\text { Batch } \\
\text { 7.5ii }\end{array}$ & $\begin{array}{l}\text { Batch } \\
11.25 \\
\end{array}$ & $\begin{array}{c}\text { Batch } \\
15 \\
\end{array}$ \\
\hline $\mathrm{Al}$ & $\begin{array}{c}7.24 \\
(0.005,0.8)\end{array}$ & $\begin{array}{c}0.0863 \\
(0.0022,2.6)\end{array}$ & $\begin{array}{l}1.15 \\
(0,0)\end{array}$ & $\begin{array}{c}0.0471 \\
(0,0)\end{array}$ & $\begin{array}{c}0.0599 \\
(0.0038,6.3)\end{array}$ & $\begin{array}{c}0.0847 \\
(0.0038,4.5)\end{array}$ & $\begin{array}{c}0.0730 \\
(0.0039,5.3)\end{array}$ \\
\hline $\mathrm{Ca}$ & $\begin{array}{c}5180 \\
(130,2.4)\end{array}$ & $\begin{array}{c}4390 \\
(6,0.1)\end{array}$ & $\begin{array}{c}4330 \\
(76,1.8)\end{array}$ & $\begin{array}{c}4330 \\
(28,0.6)\end{array}$ & $\begin{array}{l}4270 \\
(0,0)\end{array}$ & $\begin{array}{c}4120 \\
(33,0.8)\end{array}$ & $\begin{array}{c}3390 \\
(55,1.6)\end{array}$ \\
\hline $\mathrm{Cu}$ & $\begin{array}{c}105 \\
(0.6,0.5)\end{array}$ & $\begin{array}{c}0.212 \\
(0.0033,1.6)\end{array}$ & $\begin{array}{c}14.2 \\
(0,0)\end{array}$ & $\begin{array}{l}0.292 \\
(0,0)\end{array}$ & $\begin{array}{l}0.839 \\
(0,0)\end{array}$ & $\begin{array}{l}1.17 \\
(0,0)\end{array}$ & $\begin{array}{l}2.16 \\
(0,0)\end{array}$ \\
\hline $\mathrm{Fe}$ & $<0.00776$ & $<0.00807$ & $<0.00768$ & $<0.00785$ & $<0.00762$ & $<0.00773$ & $<0.00780$ \\
\hline $\mathrm{K}$ & $\begin{array}{c}514 \\
(1.6,0.3)\end{array}$ & $\begin{array}{c}376 \\
(0.6,0.1)\end{array}$ & $\begin{array}{c}456 \\
(3.3,0.7)\end{array}$ & $\begin{array}{c}464 \\
(2.8,0.6)\end{array}$ & $\begin{array}{c}488 \\
(22,4.4)\end{array}$ & $\begin{array}{c}362 \\
(0,0)\end{array}$ & $\begin{array}{c}441 \\
(2.2,0.5)\end{array}$ \\
\hline $\mathrm{Mg}$ & $\begin{array}{c}229 \\
(0.5,0.2)\end{array}$ & $\begin{array}{c}189 \\
(0.6,0.3)\end{array}$ & $\begin{array}{c}213 \\
(1.1,0.5)\end{array}$ & $\begin{array}{c}178 \\
(1.1,0.6)\end{array}$ & $\begin{array}{c}185 \\
(2.7,1.5)\end{array}$ & $\begin{array}{c}170 \\
(0.5,0.3)\end{array}$ & $\begin{array}{c}157 \\
(1.1,0.7)\end{array}$ \\
\hline $\mathrm{Mn}$ & $\begin{array}{c}5200 \\
(110,2.1)\end{array}$ & $\begin{array}{c}3430 \\
(16,0.5)\end{array}$ & $\begin{array}{c}4620 \\
(110,2.5)\end{array}$ & $\begin{array}{c}3190 \\
(11,0.3)\end{array}$ & $\begin{array}{c}3870 \\
(5,0.1)\end{array}$ & $\begin{array}{c}3550 \\
(11,0.3)\end{array}$ & $\begin{array}{c}3050 \\
(22,0.7)\end{array}$ \\
\hline $\mathrm{Ni}$ & $\begin{array}{c}718 \\
(1.6,0.2)\end{array}$ & $\begin{array}{c}8.67 \\
(0.055,0.6)\end{array}$ & $\begin{array}{c}356 \\
(0.5,0.2)\end{array}$ & $\begin{array}{c}7.20 \\
(0.0056 \\
0.1)\end{array}$ & $\begin{array}{c}58.5 \\
(0.05,0.1)\end{array}$ & $\begin{array}{c}40.2 \\
(0.27,0.7)\end{array}$ & $\begin{array}{c}60.8 \\
(0.39,0.6)\end{array}$ \\
\hline $\mathrm{S}$ & $\begin{array}{c}414 \\
(5.7,1.3)\end{array}$ & $\begin{array}{c}348 \\
(3.3,0.9)\end{array}$ & $\begin{array}{c}423 \\
(9.2,2.2)\end{array}$ & $\begin{array}{c}360 \\
(1.7,0.5)\end{array}$ & $\begin{array}{c}401 \\
(2.7,0.7)\end{array}$ & $\begin{array}{c}339 \\
(4.4,1.3)\end{array}$ & $\begin{array}{c}373 \\
(0.6,0.1)\end{array}$ \\
\hline $\mathrm{Si}$ & $\begin{array}{c}94.3 \\
(0.57,0.6)\end{array}$ & $\begin{array}{c}15.5 \\
(0.72,4.6)\end{array}$ & $\begin{array}{c}33.4 \\
(0.11,0.3)\end{array}$ & $\begin{array}{c}24.7 \\
(0.06 \\
0.2)\end{array}$ & $\begin{array}{c}24.1 \\
(0.05,0.2)\end{array}$ & $\begin{array}{c}41.5 \\
(0.98,2.4)\end{array}$ & $\begin{array}{c}20.9 \\
(0.39,1.8)\end{array}$ \\
\hline $\mathrm{U}$ & NA & $<0.778$ & $\begin{array}{c}662 \\
(3.8,0.6)\end{array}$ & $<0.785$ & $\begin{array}{c}7.02 \\
(0.038,0.5)\end{array}$ & $\begin{array}{c}5.46 \\
(0.027,0.5)\end{array}$ & $\begin{array}{c}12.3 \\
(0,0)\end{array}$ \\
\hline $\mathrm{Zn}$ & $\begin{array}{l}117 \\
(0,0)\end{array}$ & $\begin{array}{c}1.65 \\
(0.011,0.7)\end{array}$ & $\begin{array}{c}76.0 \\
(0.38,0.5)\end{array}$ & $\begin{array}{l}1.59 \\
(0,0)\end{array}$ & $\begin{array}{c}5.77 \\
(0.022,0.4)\end{array}$ & $\begin{array}{c}6.46 \\
(0.016,0.3)\end{array}$ & $\begin{array}{c}4.78 \\
(0.033,0.7)\end{array}$ \\
\hline $\mathrm{Zr}$ & $<0.00776$ & $<0.00778$ & $<0.00768$ & $<0.00785$ & $<0.00762$ & $<0.00773$ & $<0.00780$ \\
\hline
\end{tabular}


WSRC-TR-2004-00206

Revision 0

Table 3-9. Percent Soluble of Select Elements in SRAT Products

\begin{tabular}{cccccccc}
\hline \multirow{2}{*}{ Element } & Batch & Batch & Batch & Batch & Batch & Batch & Batch \\
& $\mathbf{0}$ & $\mathbf{3 . 7 5 - 1}$ & $\mathbf{3 . 7 5 - 2}$ & $\mathbf{7 . 5 i}$ & $\mathbf{7 . 5 i i}$ & $\mathbf{1 1 . 2 5}$ & $\mathbf{1 5}$ \\
\hline $\mathrm{Al}$ & $0.03 \%$ & $0 * \%$ & $0 \%$ & $0 \%$ & $0 \%$ & $0 \%$ & $0 \%$ \\
$\mathrm{Ca}$ & $105 \%$ & $102 \%$ & $87 \%$ & $102 \%$ & $93 \%$ & $98 \%$ & $93 \%$ \\
$\mathrm{Cu}$ & $46 \%$ & $0.09 \%$ & $6.1 \%$ & $0.14 \%$ & $0.35 \%$ & $0.46 \%$ & $0.86 \%$ \\
$\mathrm{Fe}$ & $0 \%$ & $0 \%$ & $0 \%$ & $0 \%$ & $0 \%$ & $0 \%$ & $0 \%$ \\
$\mathrm{Mg}$ & $96 \%$ & $82 \%$ & $90 \%$ & $86 \%$ & $91 \%$ & $84 \%$ & $88 \%$ \\
$\mathrm{Mn}$ & $98 \%$ & $68 \%$ & $88 \%$ & $69 \%$ & $75 \%$ & $74 \%$ & $73 \%$ \\
$\mathrm{Ni}$ & $29 \%$ & $0.32 \%$ & $13 \%$ & $0.29 \%$ & $2.1 \%$ & $1.5 \%$ & $2.7 \%$ \\
$\mathrm{~S}$ & $71 \%$ & $62 \%$ & $79 \%$ & $67 \%$ & $78 \%$ & $67 \%$ & $84 \%$ \\
$\mathrm{Si}$ & $5.5 \%$ & $0.94 \%$ & $1.9 \%$ & $1.4 \%$ & $1.5 \%$ & $2.7 \%$ & $1.6 \%$ \\
$\mathrm{U}$ & $\mathrm{NA}$ & $0.01 \%$ & $7.8 \%$ & $0.01 \%$ & $0.04 \%$ & $0.02 \%$ & $0.04 \%$ \\
$\mathrm{Zn}$ & $20 \%$ & $0.30 \%$ & $14 \%$ & $0.31 \%$ & $1.1 \%$ & $1.3 \%$ & $1.1 \%$ \\
$\mathrm{Zr}$ & $0 \%$ & $0 \%$ & $0 \%$ & $0 \%$ & $0 \%$ & $0 \%$ & $0 \%$ \\
\hline
\end{tabular}

* $0 \%$ means less than $0.00 \%$ of the total is soluble.

The values in Table 3-8 which are larger than 100\% reflect the uncertainties in the individual measurements used to calculate these percentages.

\subsubsection{X-ray Diffraction and Particle Size Analyses of Solids and Entrainment Observations}

Solids were again isolated from each of the SRAT product slurries, dried at $110^{\circ} \mathrm{C}$, and submitted for XRD analysis. The spectra obtained from these analyses are shown in Figure 3-4 through Figure 3-10. There are spectra for both SRAT cycles conducted with the nominally $3.75 \mathrm{wt} \%$ uranium containing slurry. The two spectra for the Batch 7.5 materials are separate SRAT cycle products on independently prepared SRAT feed slurries. None of the unidentified species in these spectra were uranium containing, they appeared more likely to be alumino-silicate compounds. As discussed in Section 2.1.1, the identified uranium species in the feed slurries was a hydrated uranate (Clarkeite), $\mathrm{Na}\left(\mathrm{UO}_{2}\right) \mathrm{O}(\mathrm{OH})$. The SRAT products gave no indication of Clarkeite, but generally the uranium containing species was still $\mathrm{U}(\mathrm{VI})$, specifically $\mathrm{Na}$ or $\mathrm{K}$ salts of $\mathrm{U}_{2} \mathrm{O}_{7}{ }^{2-}$. The product uranium containing species were very fine, on the order of $100 \AA$. The compounds were also not completely crystalline resulting in the broad peaks seen in the spectra.

One observation made during the SRAT cycles with several of these feeds does suggest a connection with the plant observed air-entrainment concern. The vessel volumes swelled by as much as $33 \%$ between the end of acid addition and the heat-up to boiling. The heat-up to boiling took $10-15$ minutes and therefore corresponded well with the DWPF procedural heat-up rate of $0.5^{\circ} \mathrm{C} /$ minute. The Batch 11.25 SRAT cycle had the largest volume change factor. Table 3-10 below, gives a rough estimate of the swelling factors observed for each batch of sludge material. 
Table 3-10. Observed SRAT Cycle Feed Volume Change Factors

Upon Going From $93^{\circ} \mathrm{C}$ to $100^{\circ} \mathrm{C}$

\begin{tabular}{cc}
\hline Batch No. & Volume Change Factor \\
\hline 0 & $6.2 \%$ \\
$3.75-1$ & $4.2 \%$ \\
$3.75-2$ & no change observed \\
$7.5 \mathrm{i}$ & $4.6 \%$ \\
$7.5 \mathrm{ii}$ & $6.3 \%$ \\
11.25 & $33 \%$ \\
15 & $21 \%$ \\
\hline
\end{tabular}

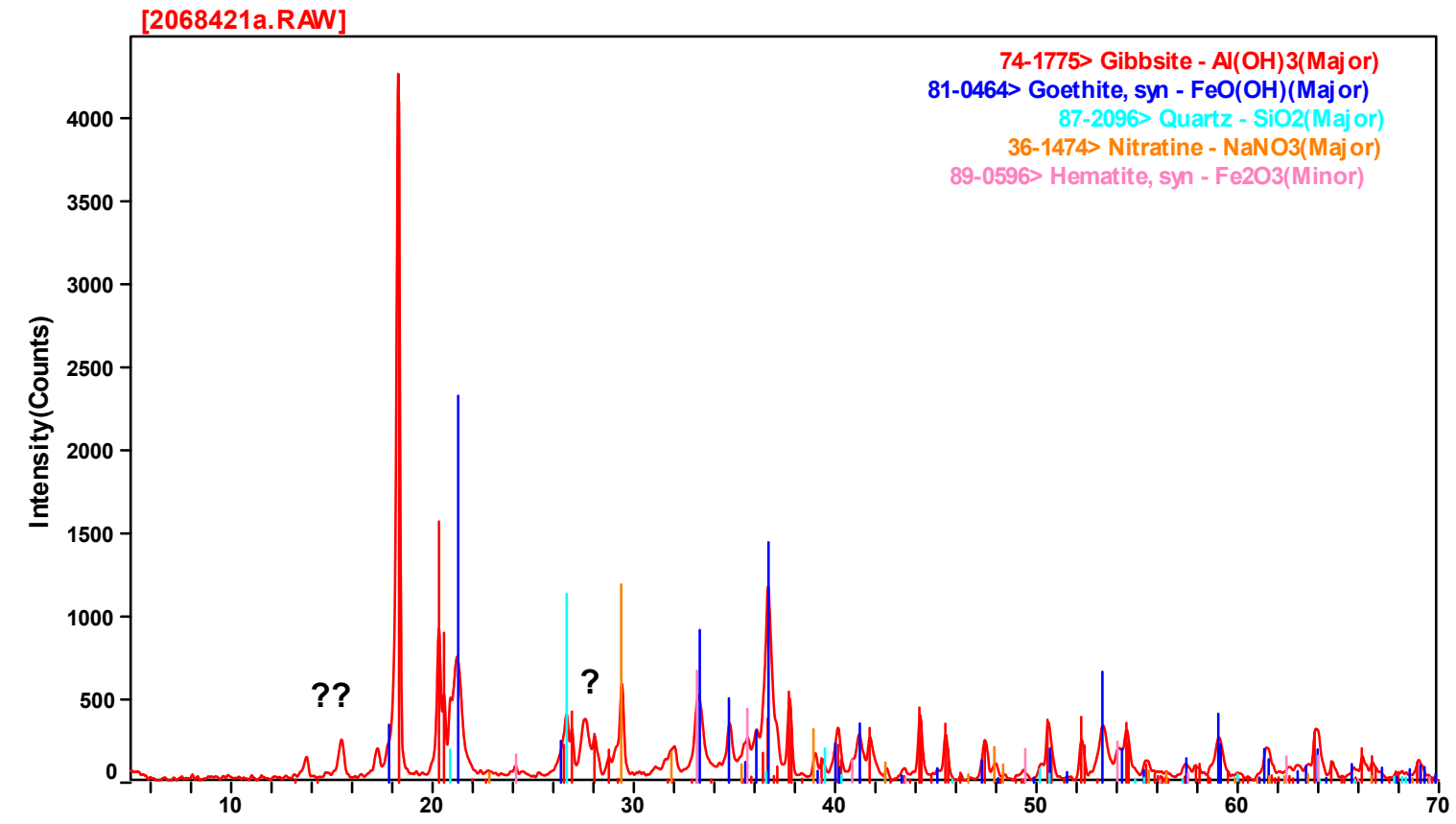

Figure 3-4. XRD Spectra of the Batch 0 SB2 SRAT Product

Unlike the starting materials, the uranium containing species in one SRAT product contained other than the $\mathrm{U}(\mathrm{VI})$ oxidation state. Specifically, the first Batch 3.75 product contained a mixed valence $\mathrm{U}_{3} \mathrm{O}_{9}{ }^{2-}$ species, possibly a single U(IV) and two U(VI). 


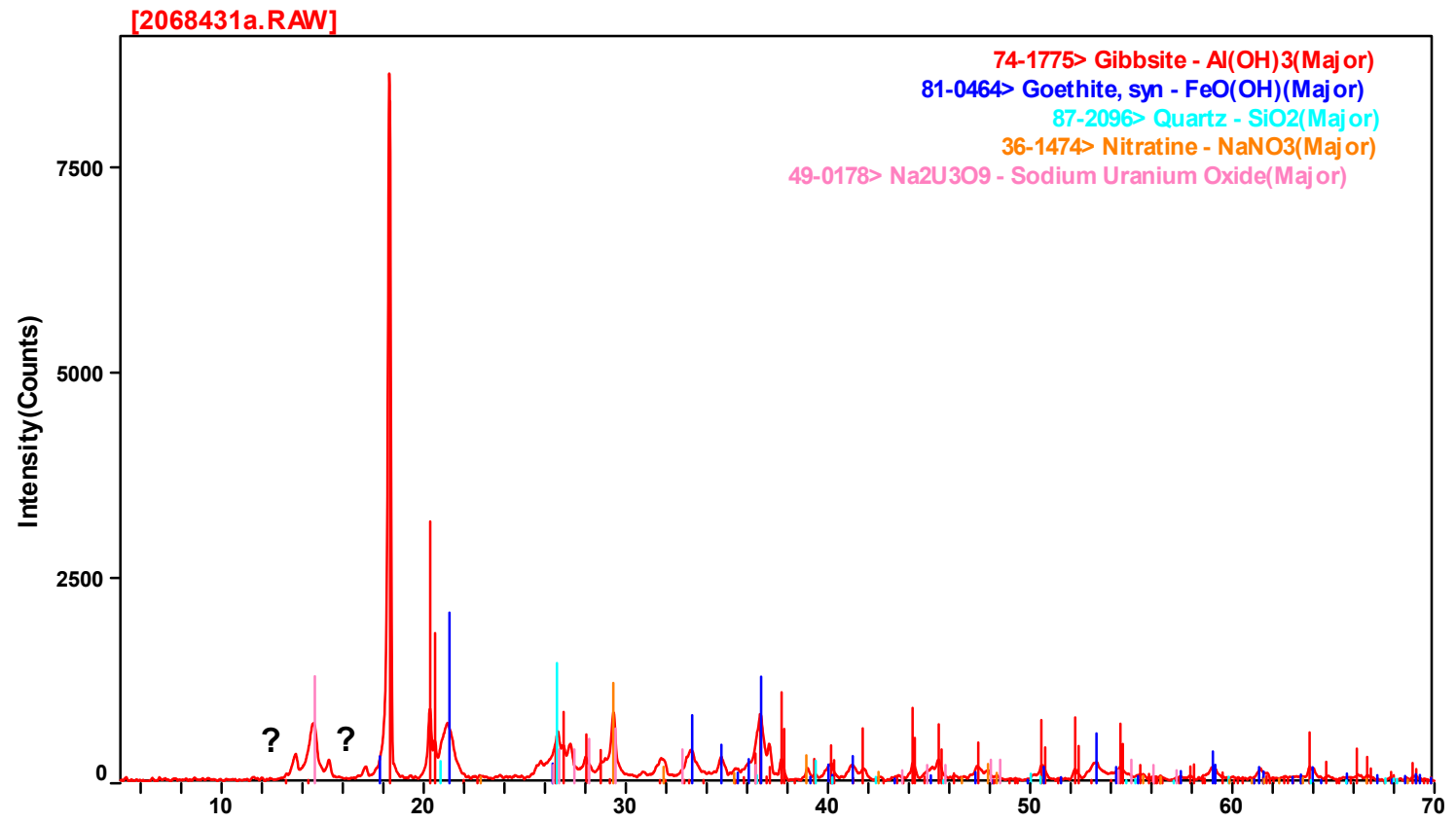

Figure 3-5. XRD Spectra of the Batch 3.75 Uranium SB2 SRAT Product, Run 1

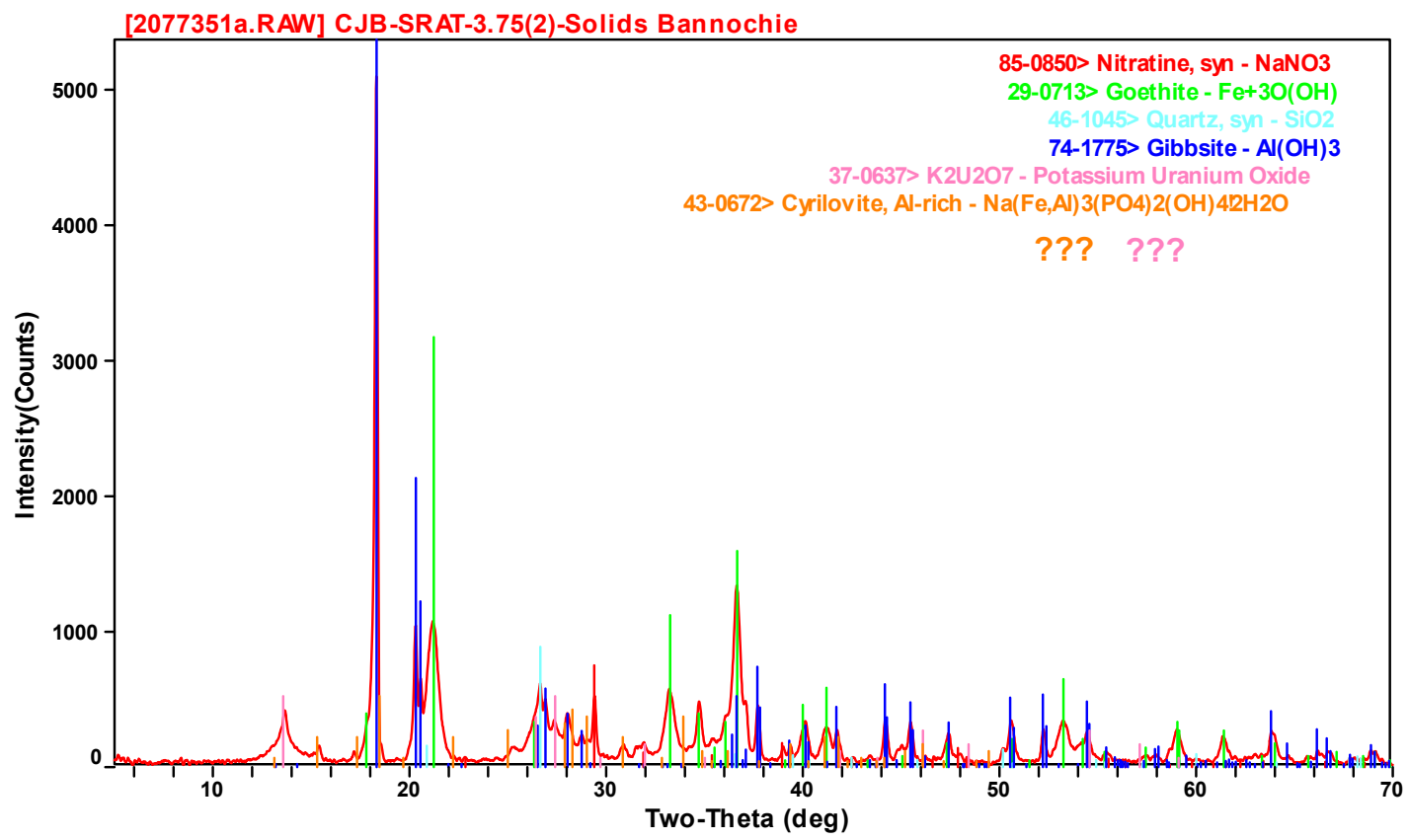

Figure 3-6. XRD Spectra of the Batch 3.75 Uranium SB2 SRAT Product, Run 2 


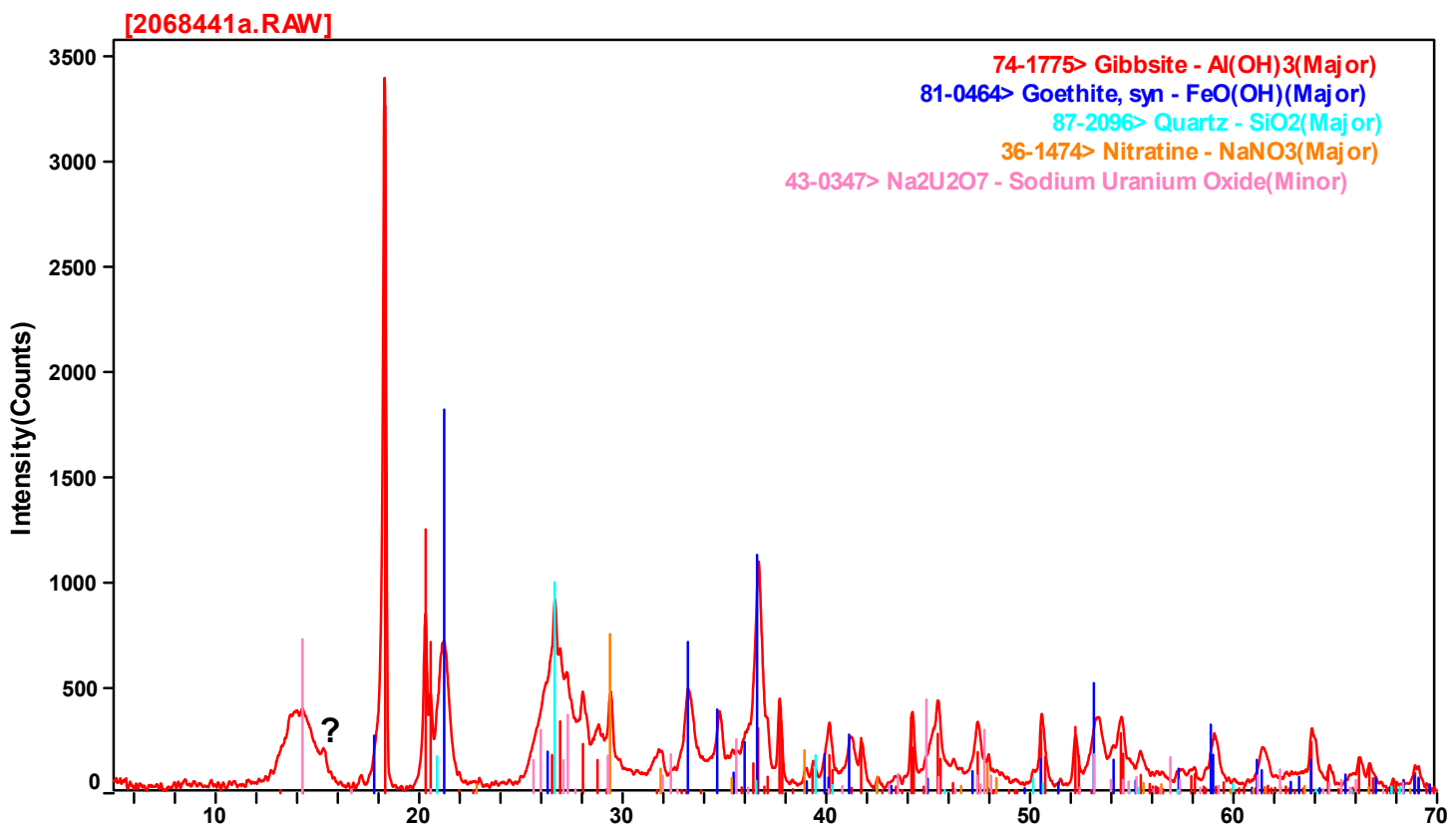

Figure 3-7. XRD Spectra of the Batch 7.5i Uranium SB2 SRAT Product

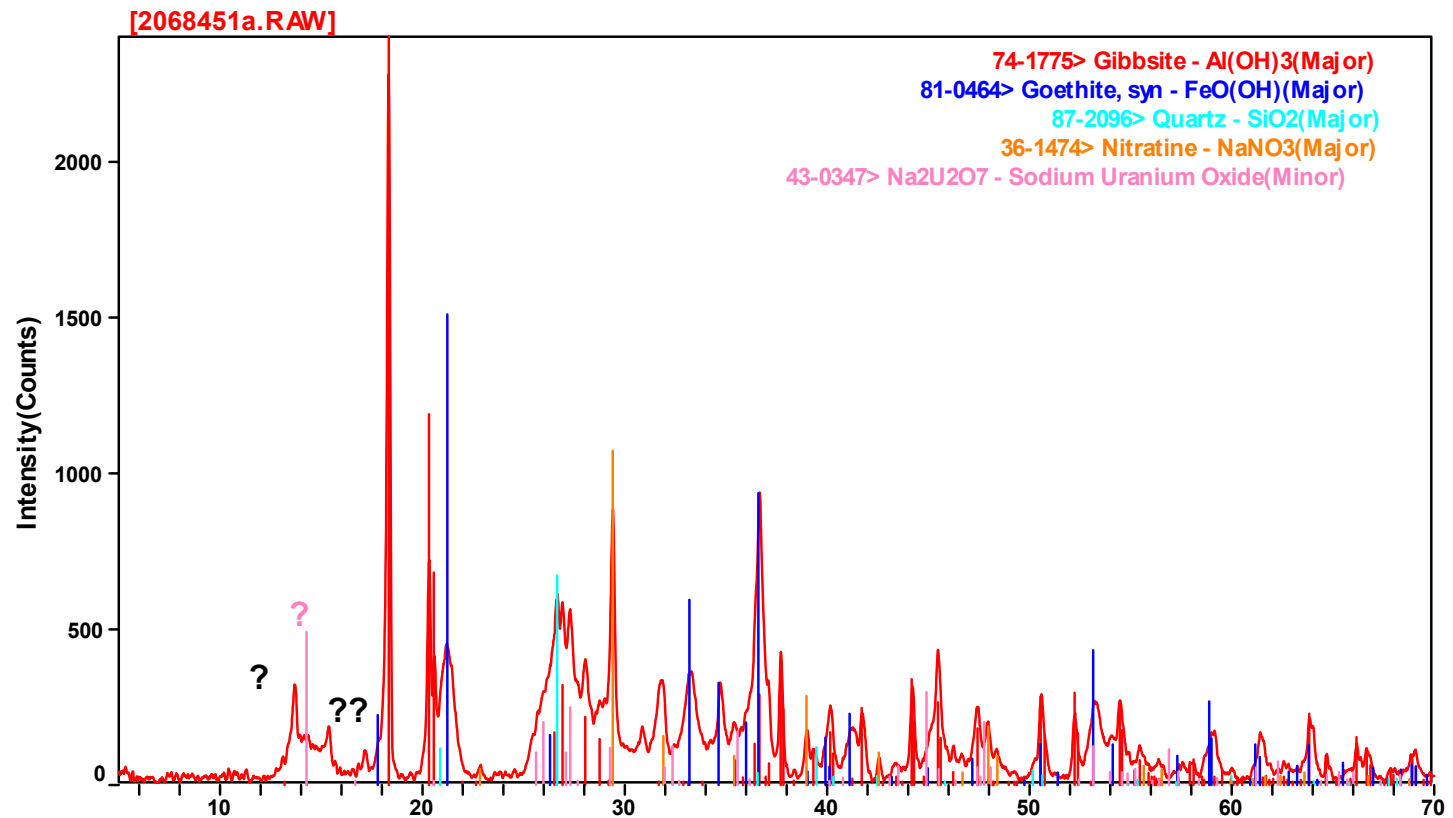

Figure 3-8. XRD Spectra of the Batch 7.5ii Uranium SB2 SRAT Product 


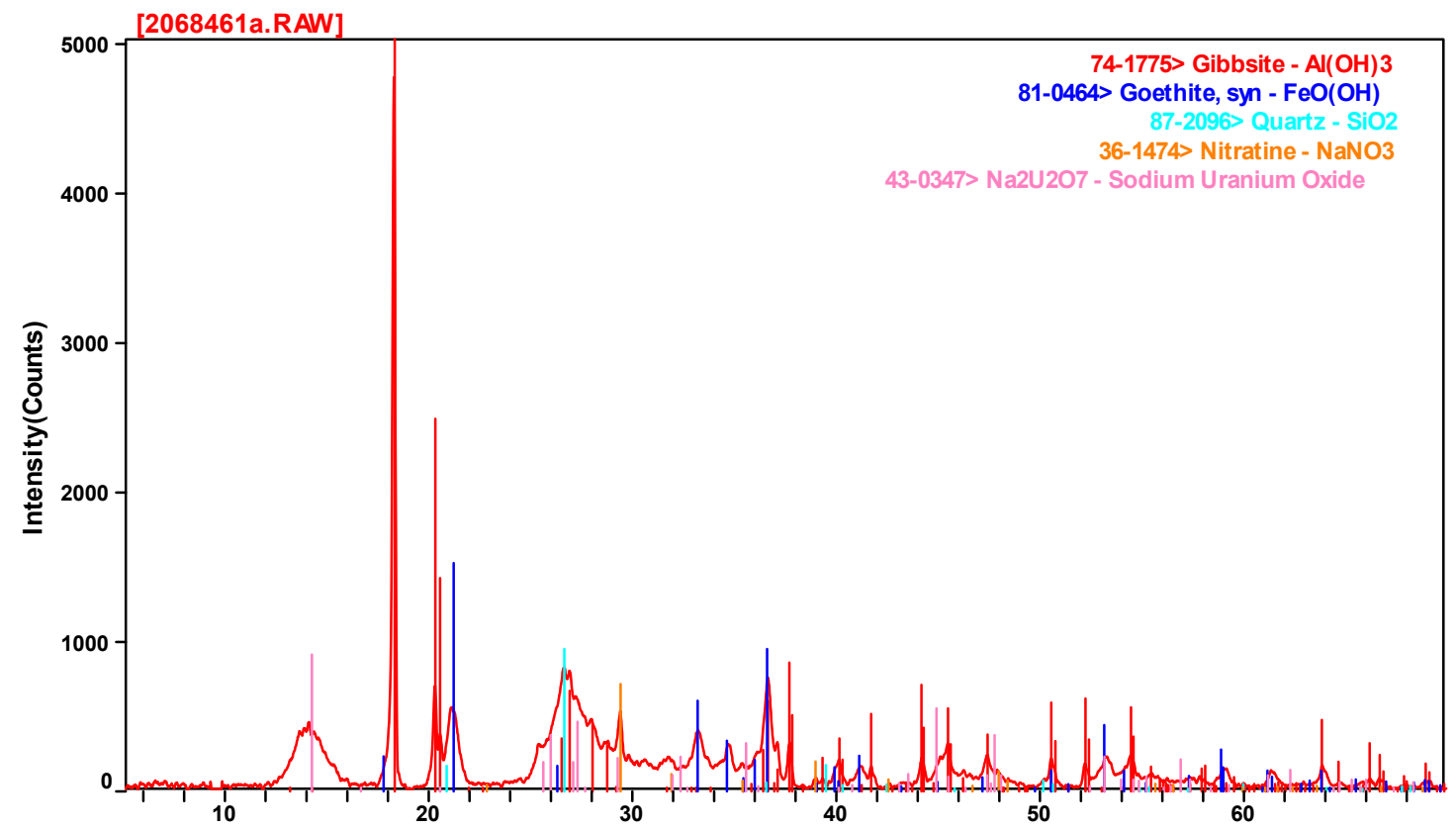

Figure 3-9. XRD Spectra of the Batch 11.25 Uranium SB2 SRAT Product

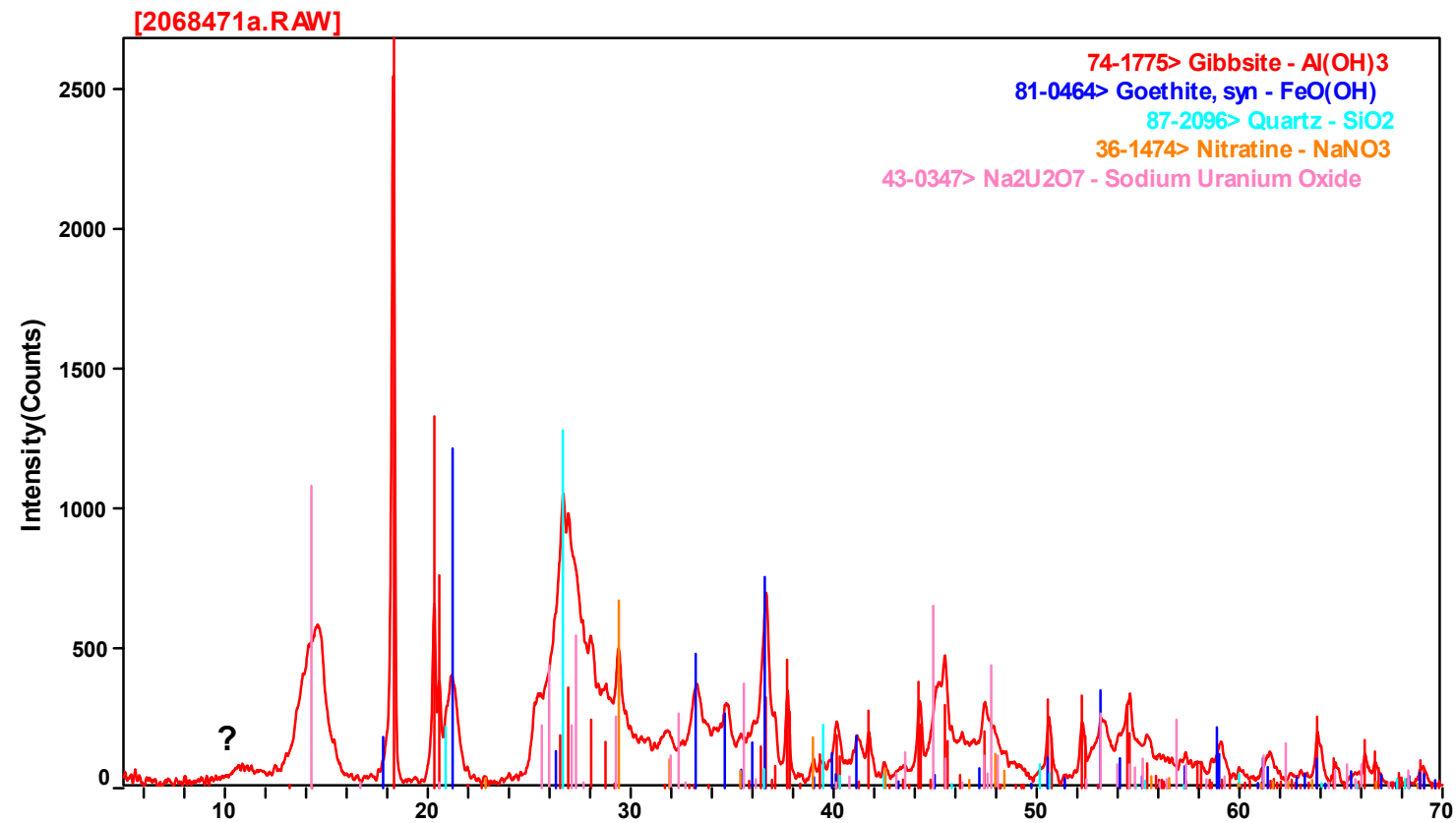

Figure 3-10. XRD Spectra of the Batch 15 Uranium SB2 SRAT Product

Table 3-11 summarizes the post SRAT processing particle parameters run on the solids. Particle size measurements were not run on the second Batch 3.75 SRAT product. There was insufficient supernate 
to use as a diluent, so these data were collected from dilution with deionized water. The impact of the deionized water on the insoluble solids is unknown. The full Microtrac volume and number distribution diagrams are provided in Appendix C. The mean diameter of the volume distribution (mv) varies from $14-28 \mu \mathrm{m}$, essentially the same as in the starting feeds (refer to Table 2-12), though there was a reduction for each sludge individually. The mean diameter of the number distribution $(\mathrm{mn})$ varies from $1.0-2.9 \mu \mathrm{m}$, a significant reduction from that measured range in the starting feeds $(1.9-3.9 \mu \mathrm{m})$, and again the reduction was reflected in each sludge processed with the percent change varying from $19-$ $56 \%$ for an individual Batch. The mean diameter value for $95 \%$ of the particles was reduced in each sludge following SRAT processing.

Table 3-11. SRAT Cycle Products Particle Size Analyses (values in $\mu \mathrm{m}$ )

\begin{tabular}{cccc}
\hline Batch No. & mv & mn & $\mathbf{9 5}^{\text {th }}$ Percentile \\
\hline 0 & 28 & 1.0 & $\leq 2.6$ \\
$3.75-1$ & 16 & 2.4 & $\leq 5.8$ \\
$7.5 \mathrm{i}$ & 14 & 2.9 & $\leq 6.2$ \\
$7.5 \mathrm{ii}$ & 14 & 2.9 & $\leq 5.7$ \\
11.25 & 14 & 2.1 & $\leq 5.0$ \\
15 & 23 & 1.2 & $\leq 3.2$ \\
\hline
\end{tabular}

\subsubsection{Product Rheological Results}

There were two post-run rheological measurements on each SRAT product. Both measurements were typically made within 24 hours of the completion of the SRAT cycle. The six simulants were each run through one SRAT cycle except for the Batch 3.75 simulant. Two SRAT cycles were run starting with fresh 3.75 simulant, designated 3.75-1 and 3.75-2. The post-run SRAT product rheology measurements occurred on the following days.

Table 3-12. Dates for SRAT Product Rheological Measurements

\begin{tabular}{cc}
\hline Batch No. & Date Measured \\
\hline 0 & $2 / 19 / 2004$ \\
$3.75-1$ & $2 / 24 / 2004$ \\
$3.75-2$ & $4 / 7 / 2004$ \\
$7.5 \mathrm{i}$ & $2 / 11 / 2004$ \\
$7.5 \mathrm{ii}$ & $3 / 5 / 2004$ \\
11.25 & $2 / 27 / 2004$ \\
15 & $3 / 3 / 2004$ \\
\hline
\end{tabular}

Rheological analyses on the seven SRAT products were identical to those made on the six starting sludges, Appendix G. The seven SRAT products exhibited varying degrees of thixotropy, or thinning with time under shear. This was more pronounced than in most other recent simulant SRAT products. This trait was present in the starting sludges, and appears to have been unaffected by SRAT processing. The seven samples when vigorously shaken showed a negligible tendency to entrain air.

The appearance of typical up ramp flow curves, given in Figure 3-11, is visibly different from that of the starting sludges, compare to Figure 2-8. The Batch 7.5ii SRAT product was still relatively thick compared to Batch 7.5i, but Batch 11.25 and 15 SRAT products were observed to have thickened relative to the $0,3.75$ and $7.5 \mathrm{i}$ SRAT products and sludges. The fourteen complete flow curves are given in Appendix F. 


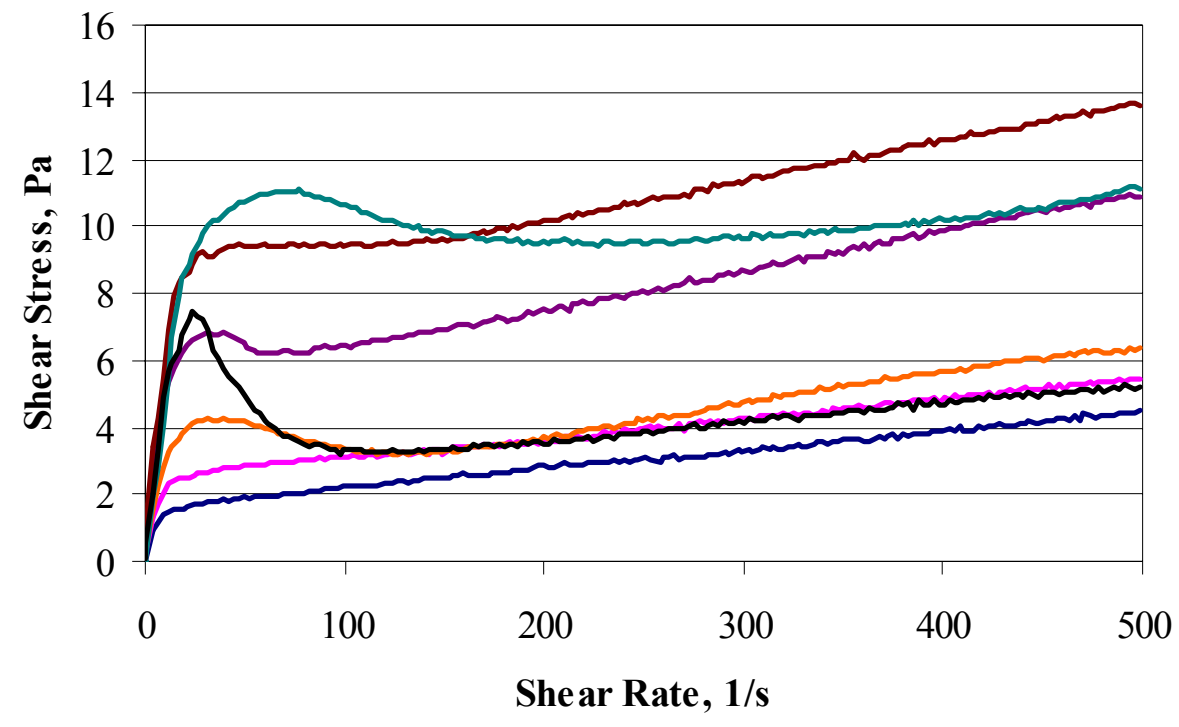

$-0-3.75-1-7.5 \mathrm{i}-11.25-15-7.5 \mathrm{ii}-3.75-2$

Figure 3-11. Typical Up Ramp Flow Curves of the SRAT Products

The down flow curves, Figure 3-12, were essentially free of abnormal structures.

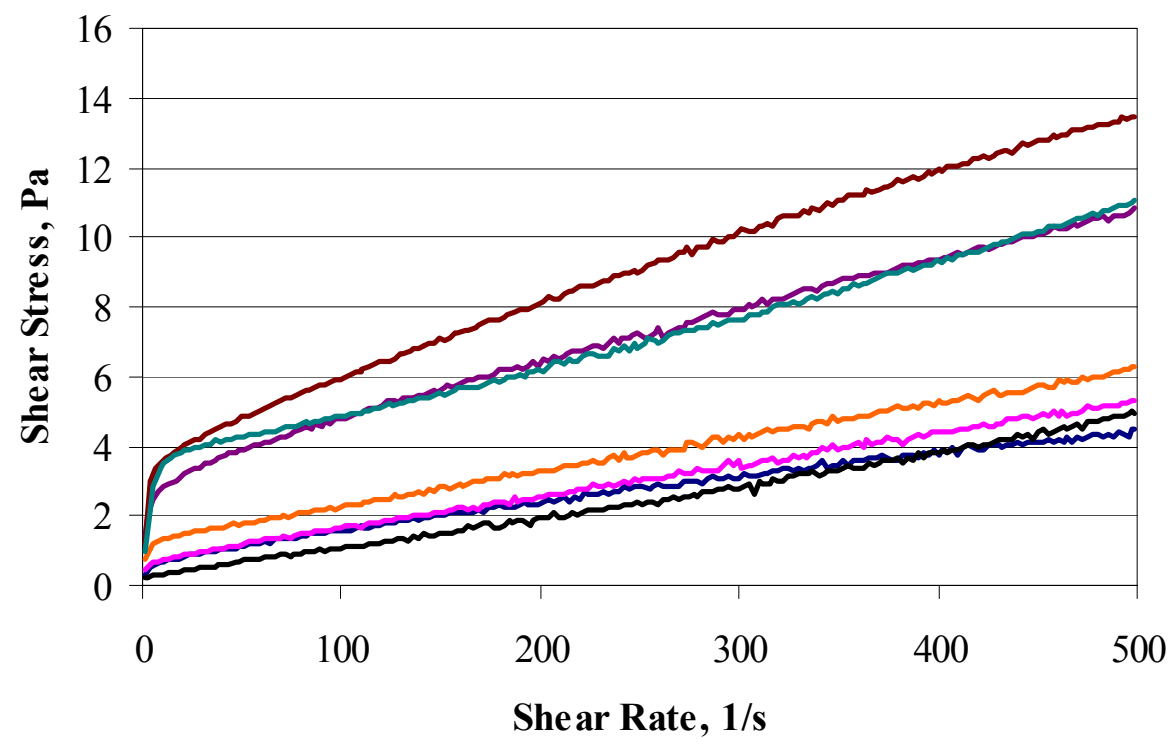

$-0-3.75-1-7.5 \mathrm{i}-11.25-15-7.5 \mathrm{ii}-3.75-2$

Figure 3-12. Typical Down Ramp Flow Curves of SRAT Products

The SRAT products as a group were more rheologically problematic than the starting sludges. Humps of varying size (Batches 3.75, 7.5, and 11.25) and an elevated plateau (Batch 15) were seen in the up ramp flow curves of the SRAT products. These occurred between $0 / \mathrm{s}$ and $\sim 150 / \mathrm{s}$. This limited Bingham plastic model fits to the region beyond the hump $(\sim 150 / \mathrm{s}-500 / \mathrm{s})$. All down ramp flow curves were fit (Appendix G) to the data from 30/s to 500/s shear rate. Fitting data to the Bingham plastic model was 
only satisfactory in providing a relative ranking of the SRAT products due to the thixotropic nature of the samples (time independent model being fit to time dependent data). The DWPF target operating region for sludge was taken to be a yield stress between 15 and 50 dynes $/ \mathrm{cm}^{2}$ and a consistency of 5-12 $\mathrm{cP}^{4}$. Table 3-13 below summarizes the fitting results. Although the last three up ramp yield stresses were outside the DWPF Operating Region, the samples were still fairly fluid and poured easily.

Table 3-13. SRAT product Bingham plastic model parameters

\begin{tabular}{|c|c|c|c|c|c|}
\hline Batch No. & $\begin{array}{l}\text { Yield Stress } \\
\text { Up ramp } \\
\text { Dynes } / \mathbf{c m}^{2}\end{array}$ & $\begin{array}{l}\text { Yield Stress } \\
\text { Down ramp } \\
\text { Dynes } / \mathrm{cm}^{2}\end{array}$ & $\begin{array}{c}\text { Consistency } \\
\text { Up ramp } \\
\text { cP }\end{array}$ & $\begin{array}{c}\text { Consistency } \\
\text { Down ramp } \\
\text { cP }\end{array}$ & pH \\
\hline 0 & 18 & 11 & 6.1 & 7.9 & 4.81 \\
\hline $3.75-1$ & 26 & 8.0 & 5.5 & 9.2 & 6.62 \\
\hline $3.75-2$ & 22 & 0.5 & 6.3 & 9.5 & 5.79 \\
\hline $7.5 \mathrm{i}$ & 19 & 12 & 9.2 & 10. & 6.54 \\
\hline $7.5 \mathrm{ii}$ & 92 & 44 & 6.3 & 16 & 6.37 \\
\hline 11.25 & 52 & 33 & 12 & 15 & 6.40 \\
\hline 15 & 82 & 46 & 12 & 19 & 6.16 \\
\hline $\begin{array}{c}\text { DWPF Operating } \\
\text { Region }\end{array}$ & $15-50$ & $15-50$ & $5-12$ & $5-12$ & NA \\
\hline
\end{tabular}

Two trends are again evident in the data. The yield stress fell, and the consistency increased, between the up ramp and the down ramp in all seven cases. The yield stress fell by roughly $8-50 \mathrm{dynes} / \mathrm{cm}^{2}$, and the consistency increased by roughly $1-9 \mathrm{cP}$. This is a consequence of the thixotropic behavior of the SRAT products. The ranges in variations were larger, however, than were seen for the starting sludges.

A trend due to the depleted uranium content was detected in the SRAT products; see Figure 3-13 and Figure 3-14 The Batch 11.25 and 15 SRAT products became relatively thicker as a consequence of SRAT processing. The other four systems did not show much change (analysis of the 7.5ii SRAT product was difficult due to the shape of the curve).

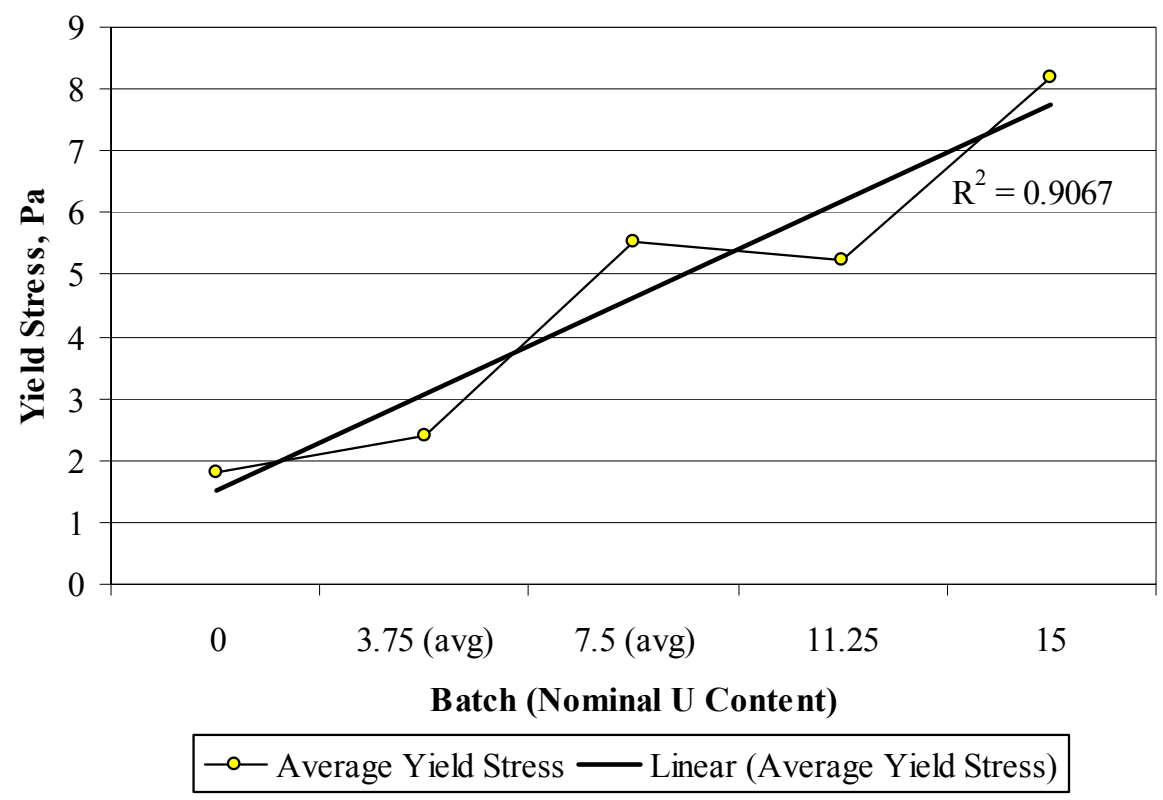

Figure 3-13. SRAT Product Yield Stress versus Nominal Uranium Level (Up Curve Basis) 
Yield stresses from the two SRAT products from Batch 3.75 simulant were averaged into a single data point in order to avoid weighting the two runs disproportionately in the regression analysis. Individually, Batch 3.75 SRAT 1 had a yield stress of $2.6 \mathrm{~Pa}$, and SRAT 2 had a yield stress of 2.2 Pa. These measurements are consistent with our understanding of the effect of $\mathrm{pH}$ on yield stress, but based upon wt \% solids measurements, the effects are possibly reversed. This difference is probably due to the lower pH of SRAT 2 as compared to SRAT 1. Yield stresses from the two SRAT products from the Batch 7.5i and 7.5ii runs were also averaged into a single data point.

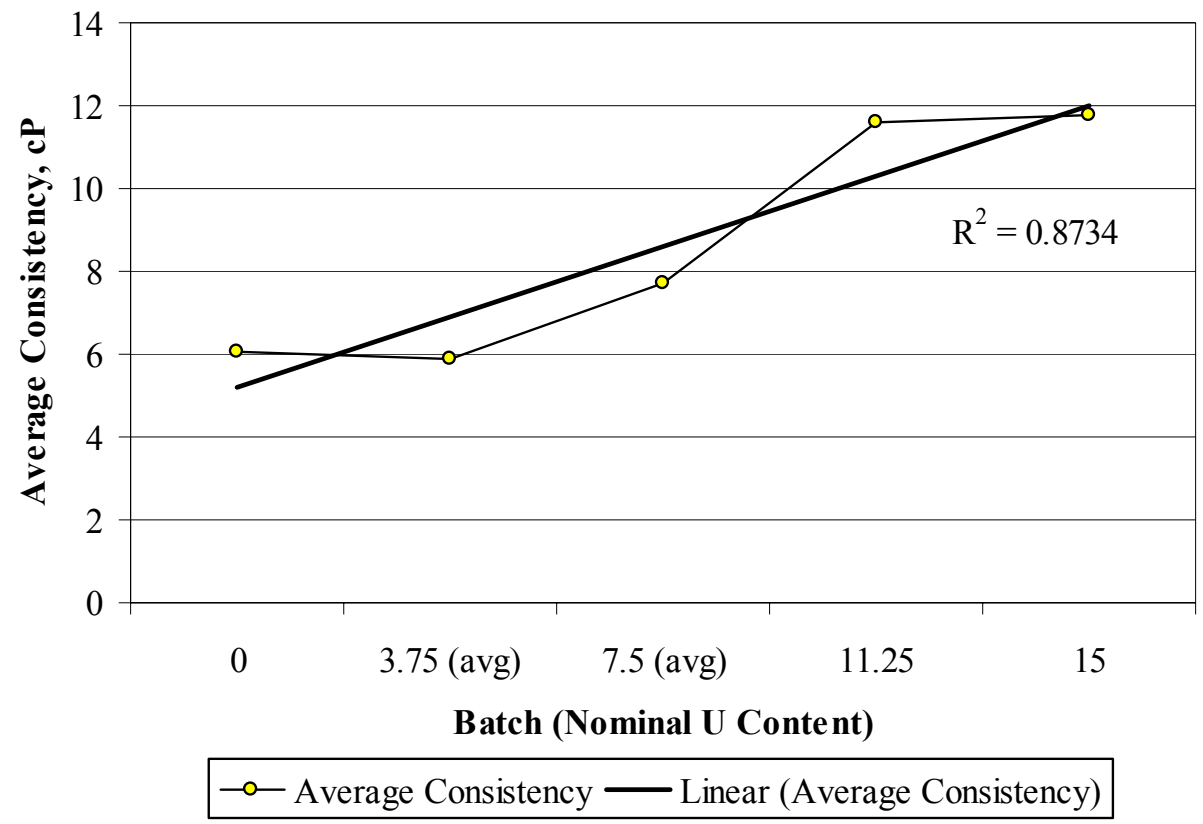

Figure 3-14. SRAT Product Consistency versus Nominal Uranium Level (Up Curve Basis)

Consistencies from the two SRAT products from Batch 3.75 simulant were averaged into a single data point. Consistencies from the SRAT products from the Batch 7.5i and 7.5ii runs were averaged into a single data point. Both the yield stress and the consistency trends with nominal uranium content appear to be statistically significant, i.e. there was greater than a $95 \%$ likelihood that both the yield stress and the consistency depended on the uranium content by analysis of variance ( $\mathrm{F}<0.02$ in both cases). Due to the large uncertainty in the data from the 7.5i and 7.5ii runs, the $\mathrm{R}^{2}$ values in Figure 3-13 and Figure 3-14 may not fully reflect the uncertainty in any values derived from these figures.

The down ramp flow curves consistently fell below the up flow curves over the entire range of shear rates. This difference was largest at low shear rates. This thixotropic behavior was investigated further. There were some issues with the manual instrument zero function that impacted some of the early data. Later data are given below for the Batch 7.5ii SRAT product in Figure 3-15, at which point the instrument issues had been resolved. 
WSRC-TR-2004-00206

Revision 0

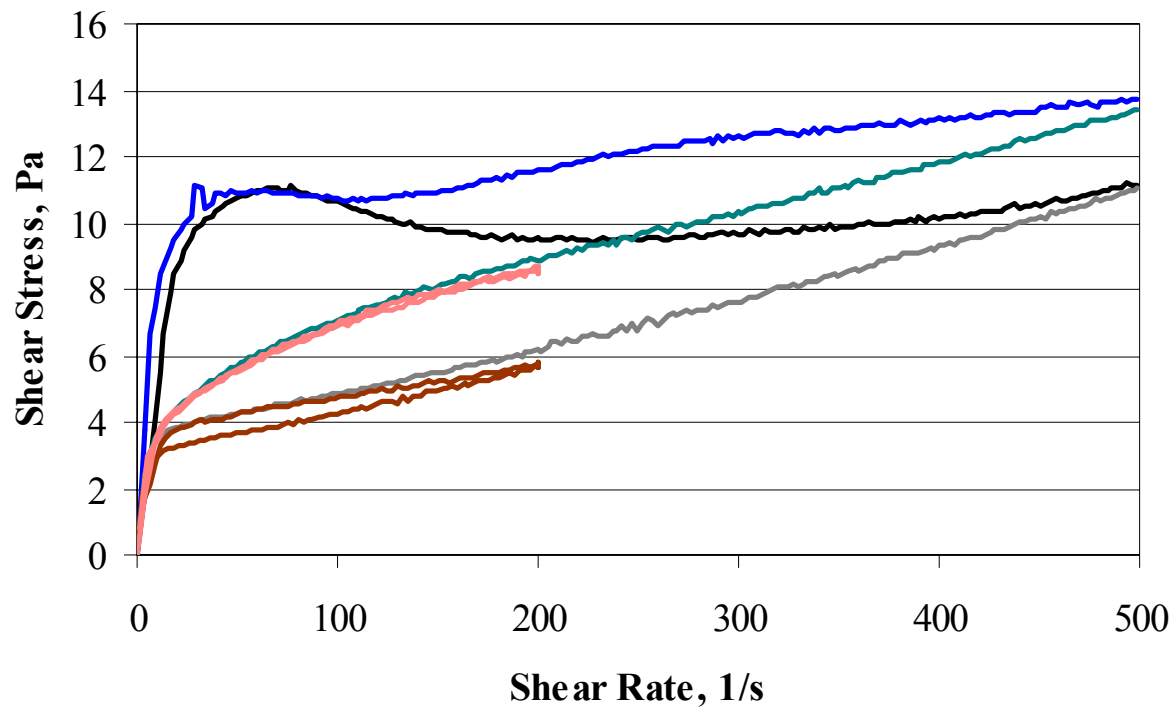

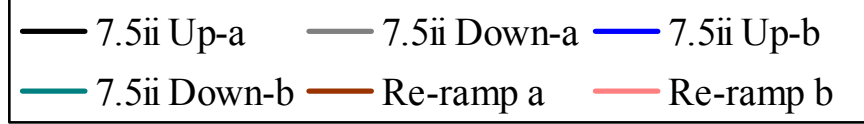

Figure 3-15. Re-Ramping the Batch 7.5ii SRAT Products

Two observations are noteworthy in the re-ramp data. First, there was no hump in the up ramp portion of either flow curve during the re-ramp to 200/s shear rate. Second, there was little further thinning of the flow curve during the re-ramp relative to the down flow curve. In the numerical analyses presented in Table 2-15 and Table 3-13, the Bingham model yield stresses and consistencies were obtained by neglecting the hump in the up ramp data. The justification for this was obtained from data such as that in Figure 3-15. Several samples that were found to have humps were kept in the rheometer after completion of the down ramp portion of the flow curve. These were then re-ramped up through the shear rate range corresponding to the hump. Nothing resembling a hump was observed on the second pass through this range of shear rates. Consequently, the humps were treated as a transient phenomenon that was irrelevant to the relative ranking of the various systems.

Reproducibility of the rheological data, as indicated by the proximity of the second flow curve (-b) to the first flow curve (-a) in Figure 3-15, was better in all other cases (sludges and SRAT products) than that seen here (see Appendices D and F for the entire set of flow curves). The variation seen here is still well within the normal ranges seen in the past. 


\subsection{DISCUSSION}

\subsection{SRAT Feeds and Products}

The variability in the two Batch 7.5 slurries indicates that there is considerable difficulty in preparing consistent sludges. Additionally, there may be factors in sludge makeup other than starting materials, precipitation temperature, and agitation rate, which need to be controlled more closely if one intends to compare or look for small differences in behavior between sludge batches. Some of these yet unidentified factors may impact particle size distributions. A greater understanding of the factors which impact sludge makeup is the subject of on-going study ${ }^{16}$ by Russ Eibling (SRNL, ITS).

The Batch 0 sludge was processed at a different redox target, 0.15 , rather than 0.20 , due to an excess addition of nitric acid, and was therefore more oxidizing than the other SRAT cycles. The $\mathrm{pH}$ was lower, but not necessarily unexpectedly lower since the second Batch 3.75 had a $\mathrm{pH}$ intermediate to that of Batches 0 and 7.5i or 7.5ii. While no acid demand due to the presence of $U$ was observed during the room temperature titrations of the SRAT feeds, this does not rule out the possibility of an acid demand by $\mathrm{U}$ during the mixed formic and nitric acid addition at elevated temperature, as occurs during a SRAT cycle. If there was such an acid demand at elevated temperature, it may be limited since there was no linear increase in final $\mathrm{pH}$ beyond the Batch 7.5 feeds. The nitrate level in Batch 0 was higher, but the measured formate ion levels are essentially constant to $\pm 10 \%$ of the mean across the series of SRAT products. The anion data has the highest degree of uncertainty of the measurements made during these experiments, so it is difficult to draw definitive conclusions from it.

The starting form of $U$ was Clarkeite, which contains U(VI). Clarkeite is a uranium species also found in actual SB2 tank waste. A comparison was made between the sludges XRD results obtained in this study and those obtained in the preliminary work with $\mathrm{U}^{5}$. The initial work only looked at the final SRAT product solids, hence no spectra were available of the starting SRAT feed materials. Archive samples allowed us to obtain spectra of the starting solids. To ascertain whether or not there had been any changes as a result of aging since the original SRAT product spectra were obtained in July 2003, one sample of the SRAT product was also submitted for analysis. The spectra obtained appear in Figure 4-1 - Figure 4-3. The spectrum of the $15 \mathrm{wt} \%$ feed was essentially like that of the $7.5 \mathrm{wt} \%$ feed and is not provided here.

The feed materials from the earlier study were not unlike those obtained in this study and contained the expected Gibbsite, Goethite, and Calcite, though no manganese containing species was identified. These results were somewhat surprising in light of the sometimes unusual species previously reported for the SRAT products ${ }^{5}$. The previous study's SRAT products indicated the presence of Hematite, $\mathrm{Fe}_{2} \mathrm{O}_{3}$, but also the less common Franklinite manganoan, $\mathrm{Zn}_{0.6} \mathrm{Mn}_{0.4} \mathrm{Fe}_{2} \mathrm{O}_{4}$ containing $\mathrm{Mn}(\mathrm{II})$, sodium aluminum silicate, $\mathrm{Na}_{1.65} \mathrm{Al}_{1.65} \mathrm{Si}_{0.35} \mathrm{O}_{4}$, and sodium aluminum iron oxide, $\mathrm{Na}_{2}(\mathrm{Al}, \mathrm{Fe})_{12} \mathrm{O}_{19}$. The resampled SRAT product from the nominally $7.5 \mathrm{wt} \%$ feed indicated none of the previously identified species, but rather the expected Gibbsite, Goethite, and Calcite. All of the Clarkeite was apparently dissolved leaving only a hint of its presence visible in Figure 4-3 with a "?" mark. This is not unexpected due to the low pH of the SRAT product at 4.45; the earlier SRAT cycles were conducted at $170 \%$ acid stoichiometry rather than $130 \%$ as done in this work. The other species obtained earlier must have resulted from a sampling issue since the samples were not homogenized prior to submission for analysis. In the spectra included here, the solids were collected by vacuum filtration, dried at $105{ }^{\circ} \mathrm{C}$ overnight (approximately $15 \mathrm{hrs}$ ), crushed to homogenize the sample, and then submitted for analysis. The only Mn containing solid in actual SB2 waste, Desautelsite, $\mathrm{Mg}_{6} \mathrm{Mn}_{2}(\mathrm{OH})_{16} \mathrm{CO}_{3} \cdot 4 \mathrm{H}_{2} \mathrm{O}$, was not found in either simulant study. In this work, Manganite, $\mathrm{Mn}(\mathrm{OH}) \mathrm{O}$, was found, which like Desautelsite contains $\mathrm{Mn}(\mathrm{III})$. 


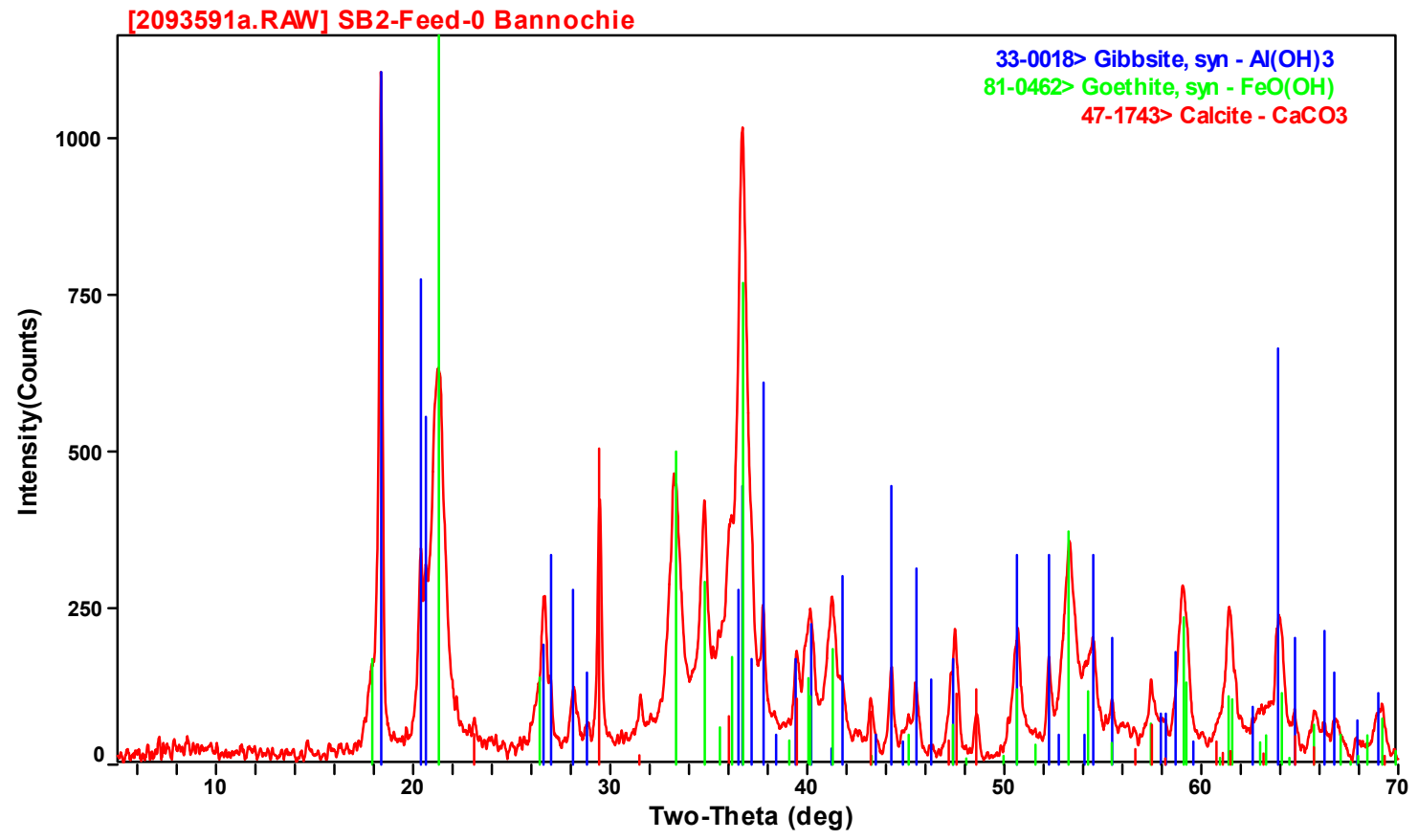

Figure 4-1. XRD Spectra of the CETL SB2 Simulant without Uranium Used in the First Impacts of U on SB2 Processing Study

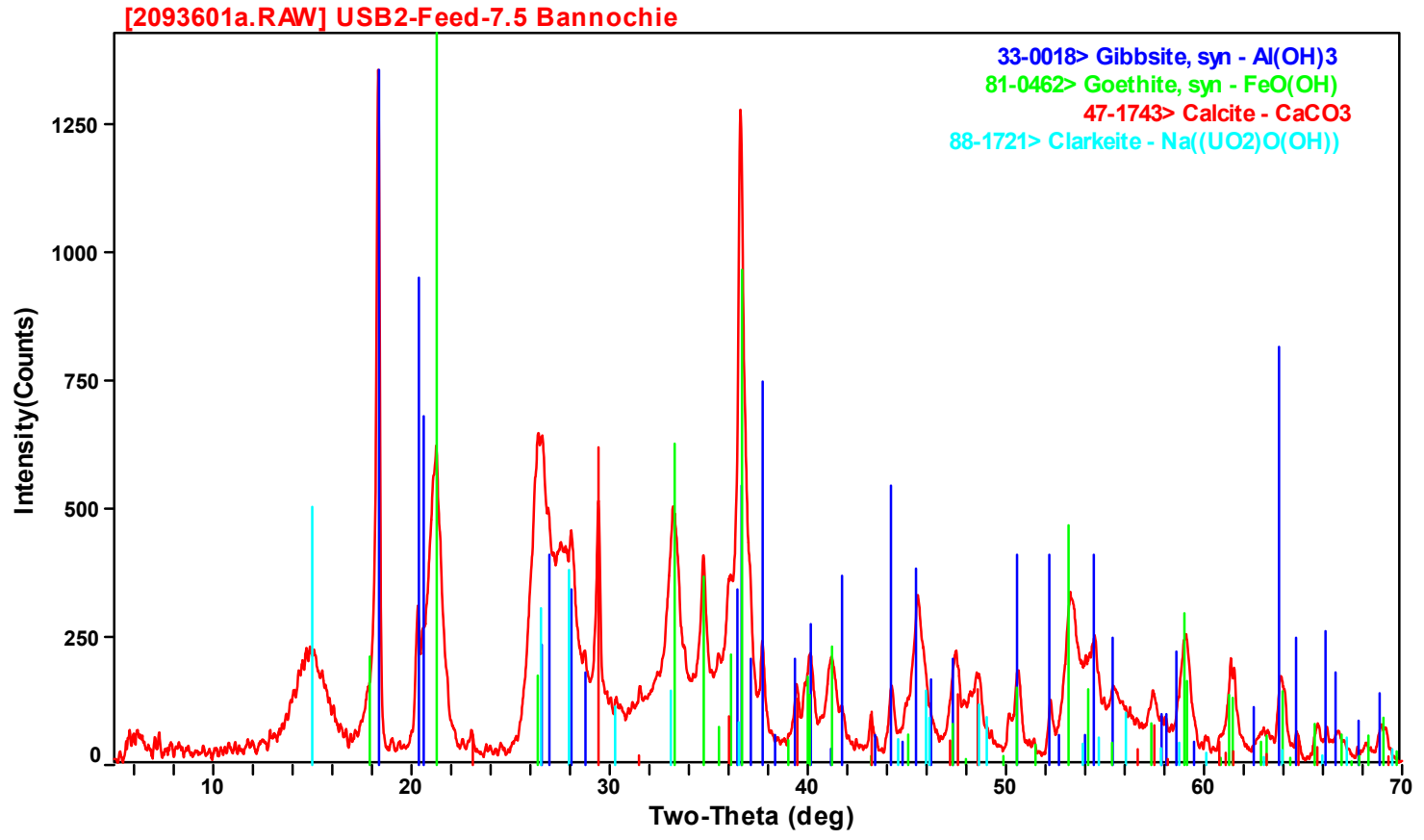

Figure 4-2. XRD Spectra of the CETL SB2 Simulant with Nominally 7.5 wt \% Uranium 


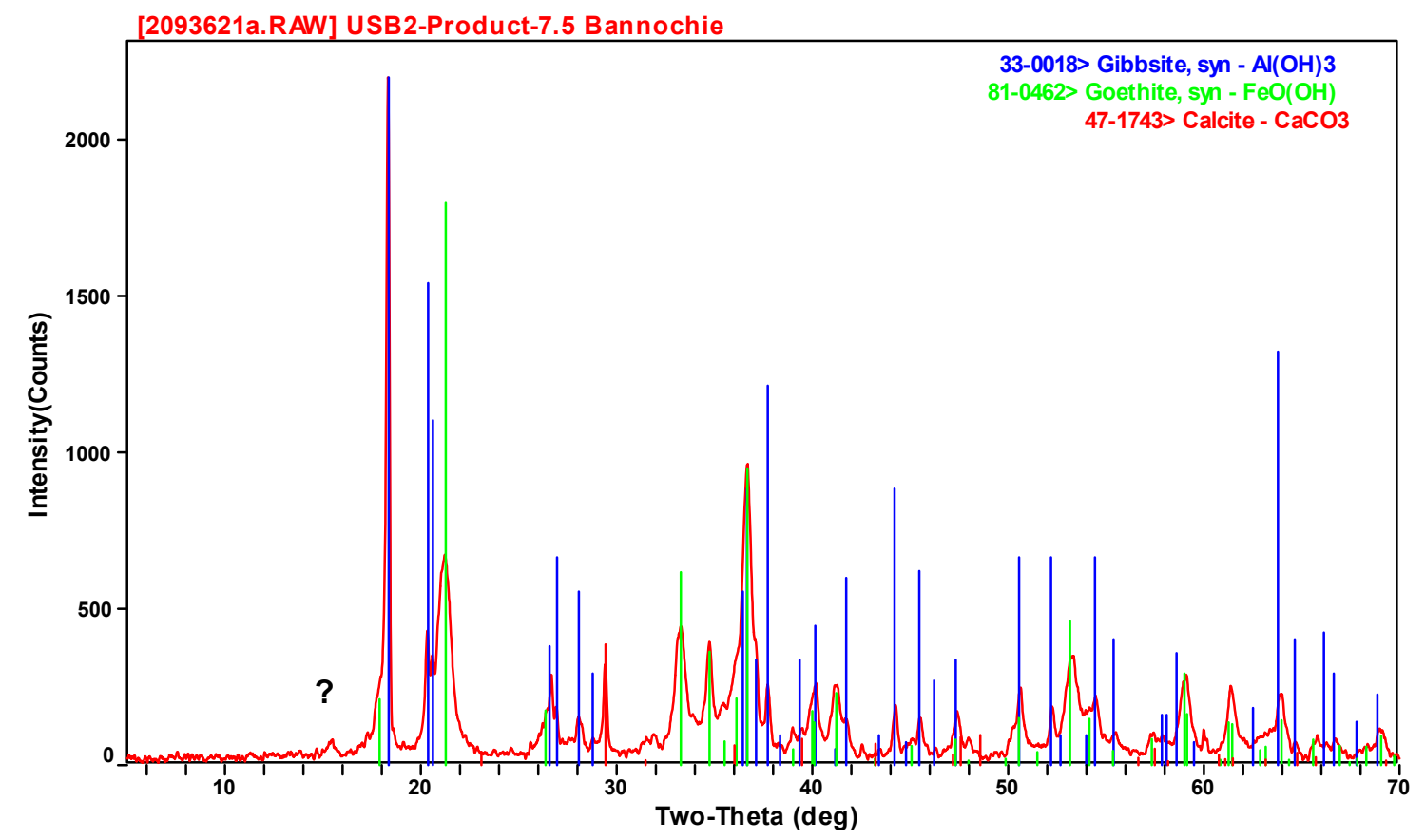

Figure 4-3. XRD Spectra of the CETL SB2 Simulant with Nominally $7.5 \mathrm{wt} \%$ Uranium Following SRAT Processing

Essentially no soluble U was found in the SRAT feeds or those products with pH values above 6 . Hence the co-precipitation of $U$ during sludge make-up did resolve an uncertainty from the preliminary $U$ work as to how representative the slurries were to actual waste sludges ${ }^{5}$. The observation of soluble $\mathrm{U}(7.8 \%)$ in the Batch 3.75 second SRAT product that had a final $\mathrm{pH}$ of 5.79 and the absence of soluble $\mathrm{U}$ in the first Batch 3.75 SRAT product with a final $\mathrm{pH}$ of 6.62, and all of the other SRAT products with final pH's above 6, would seem to indicate that the lower $\mathrm{pH}$, possibly in conjunction with the elevated temperatures of the SRAT cycle, is the primary factor in solubilizing U.

The first Batch 3.75 SRAT product had a mixed $\mathrm{U}$ oxidation state compound, $\mathrm{U}_{3} \mathrm{O}_{9}{ }^{2-}$, which was not seen in any of the other products. This mixed oxidation state species indicates that some of the uranium has likely been reduced from (VI) to (IV). The presence of a mixed oxidation state U compound indicates there is some redox activity in the system that is impacting U. This particular SRAT cycle was repeated to reproduce this mixed oxidation species and to eliminate uncertainties surrounding the higher than anticipated volume of product from the first experiment. Unfortunately, the mixed oxidation state species was not observed in the second product. The fact that it was not repeated may indicate that the factors affecting this equilibrium are not completely defined.

Particle size measurements indicated that each sludge experienced particle size reductions following SRAT cycle processing. Whether these smaller particles have a greater potential for air-entrainment is uncertain. During a review of the pulse jet system for RPP at PNNL, there was a concern over air introduction into the slurry. It was mentioned that the sludge particles could adhere to these fine bubbles (entrained air) which could lead to a foaming problem. XRD analyses of the SRAT product solids indicated the $U$ containing species were very fine, on the order of $100 \AA$, and not fully crystalline. This observation could indicate that the uranium species are dissolving and then reprecipitating during processing. The final form of the reprecipitated uranium may vary with the redox target for the batch. Therefore, the observation that finer particles result from SRAT processing, combined with the plant 
observation of entrained air, leads one to suspect that there may be a connection between the SRAT processing of high uranium containing sludges and the air-entrainment concern.

The observed swelling (refer to Table 3-10) of the SRAT slurry volumes upon heat up from $93-100{ }^{\circ} \mathrm{C}$ following completion of acid addition, may also be connected to air-entrainment. Since no mass was added to the system during heat up to boiling, the volume change must be due to entrained off-gas released from the system during the increase in temperature. The entrainment of this off-gas was highest in Batch 11.25.

An interesting question has been raised by this work. It is not clear whether the redox target of the SRAT cycle impacts the final uranium oxidation state in the sludge. The partially reduced $\mathrm{U}_{3} \mathrm{O}_{9}{ }^{2-}$ species we observed in only one SRAT product contains two U(VI) and one U(IV). This sludge species would not be expected to liberate oxygen in the melter, and therefore could not result in foaming. From a glass perspective, the uranium staying as U(VI) following the SRAT cycle, as was largely observed in this study, can be assumed to be a worst case scenario. The $\mathrm{U}$ species reported in the glass is $\mathrm{U}_{3} \mathrm{O}_{8}$, or expressed another way, two $\mathrm{U}(\mathrm{VI}) \mathrm{O}_{3}$ and one $\mathrm{U}(\mathrm{IV}) \mathrm{O}_{2}$. If all the $\mathrm{U}$ is coming to the melter as $\mathrm{U}(\mathrm{VI})$, this will result in some oxygen liberation in the melter, and therefore a potential for foaming.

\subsection{Rheology}

Comparisons of SRAT product to corresponding starting sludge were generated in addition to those limited to either the six sludges or to the seven SRAT products. These looked at each SRAT product relative to its starting sludge at a given $U$ level. They assessed the impact of SRAT processing on the slurry rheology. These comparisons were legitimate for this series, since the SRAT feeds were prepared to essentially identical criteria, and since the SRAT cycle targeted a final volume approximately the same as the volume of the starting sludge.

The seven rheological comparisons are described below in order of increasing depleted uranium content. For consistency, replicate SRAT product flow curves are blue and black, and denoted by "1" and "2", for the first measurement and the replicate. The pre-run measured flow curves of the sludges are given in red and orange. They are labeled by the date to indicate that they are the pre-run measurements, and denoted by "a" and "b", for the first measurement and the replicate.

- The Batch 0 SRAT product was qualitatively similar to (or slightly thinner than) the starting sludge. 
WSRC-TR-2004-00206

Revision 0

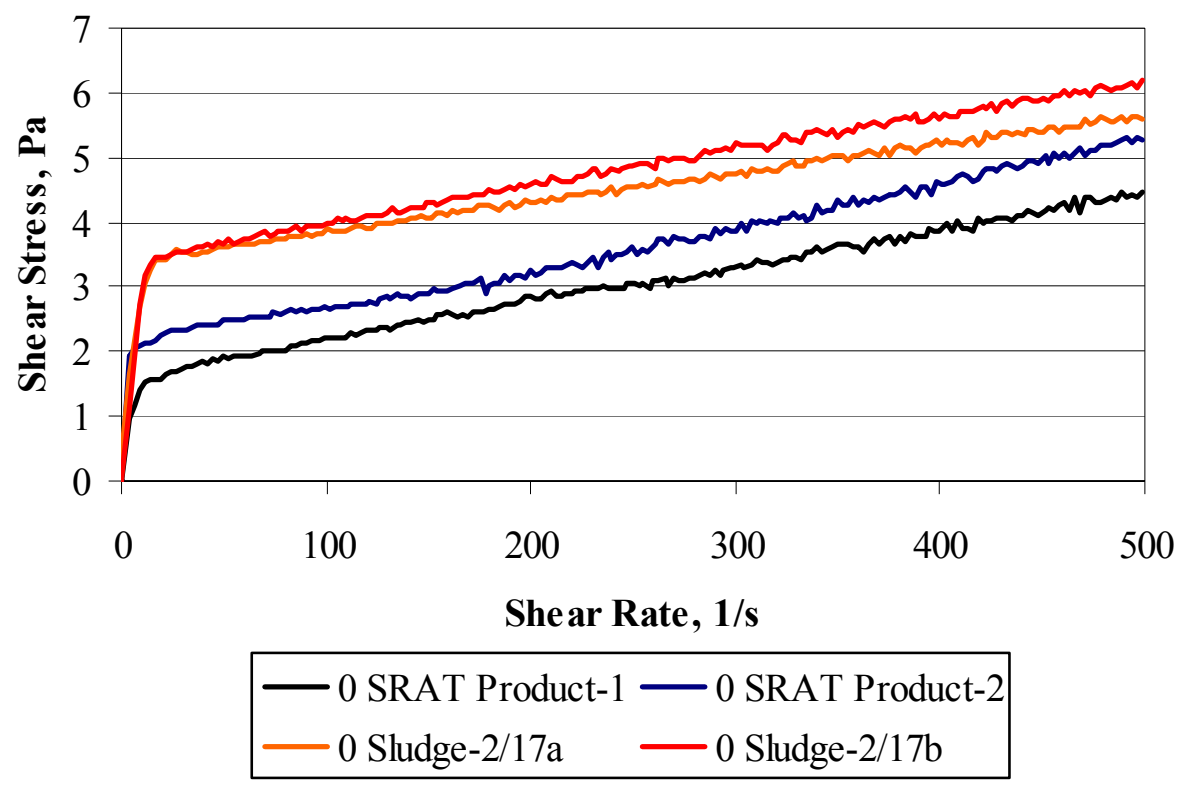

Figure 4-4. Impact of SRAT Processing, Batch 0, Up Ramp Flow Curves

- The Batch 3.75 SRAT product developed a hump in the flow curve and was slightly thicker than the starting sludge for the initial 3.75 SRAT run.

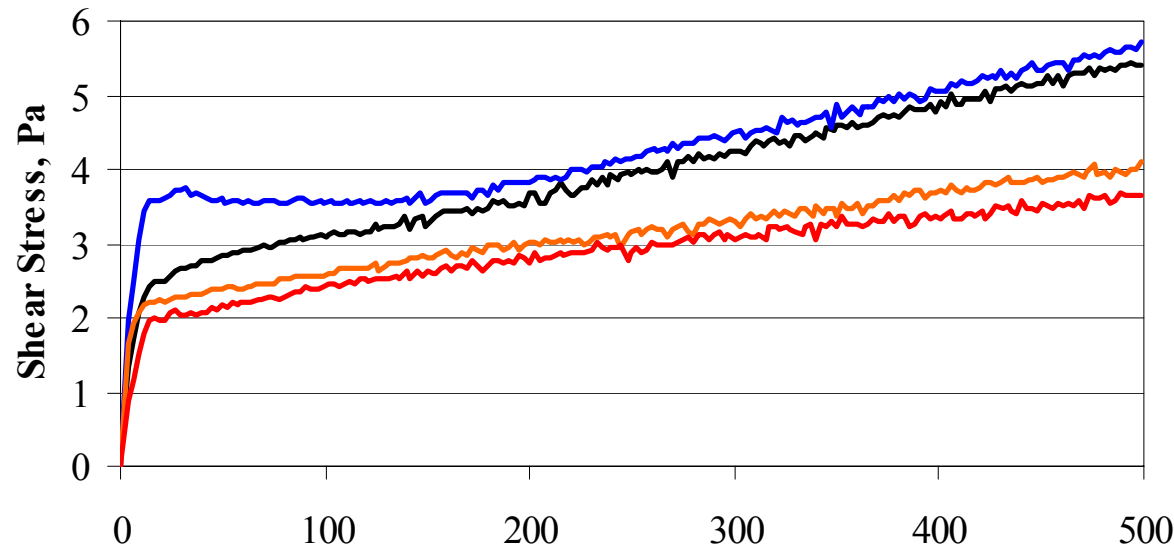

Shear Rate, $1 / \mathrm{s}$

$-3.75-1$ SRAT Product- $1-3.75-1$ SRAT Product-2
-3.75 Sludge-2/23a $\quad-3.75$ Sludge- $2 / 23 \mathrm{~b}$

Figure 4-5. Impact of SRAT Processing, Batch 3.75, Run 1, Up Ramp Flow Curves

- The Batch 3.75 SRAT product developed a pronounced hump in the flow curve and was slightly thicker than the starting sludge for the second 3.75 SRAT run. 


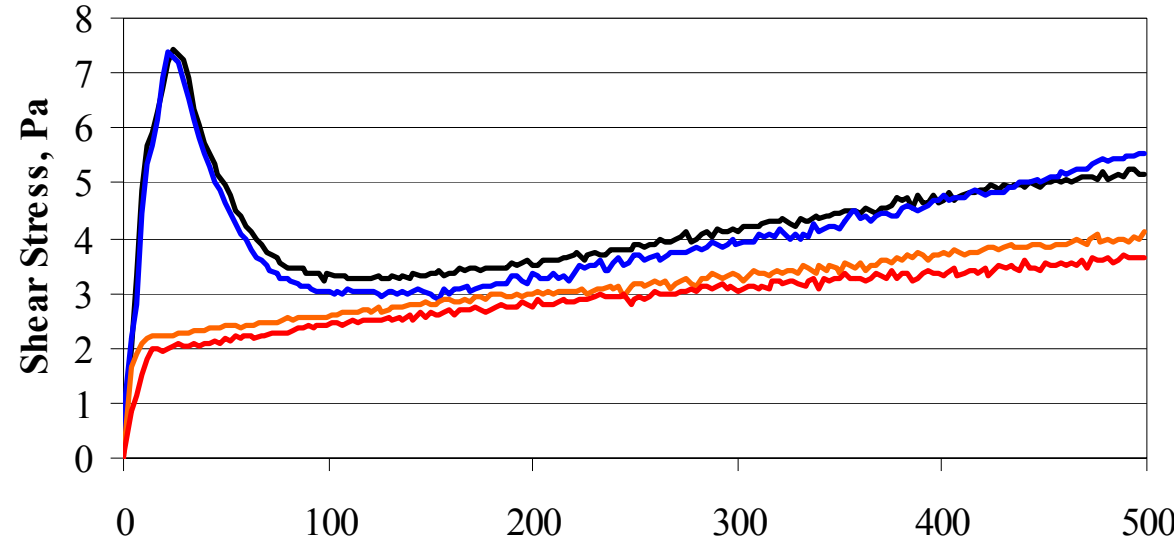

Shear Rate, $1 / \mathrm{s}$

\begin{tabular}{l} 
3.75-2 SRAT Product-1 $-3.75-2$ SRAT Product-2 \\
3.75 Sludge-2/23a -3.75 Sludge-2/23b \\
\hline
\end{tabular}

Figure 4-6. Impact of SRAT Processing, Batch 3.75, Run 2, Up Ramp Flow Curves

- The Batch 7.5i SRAT product was nearly identical to the starting sludge in rheology, except for a new hump in the up ramp portion of the flow curve.

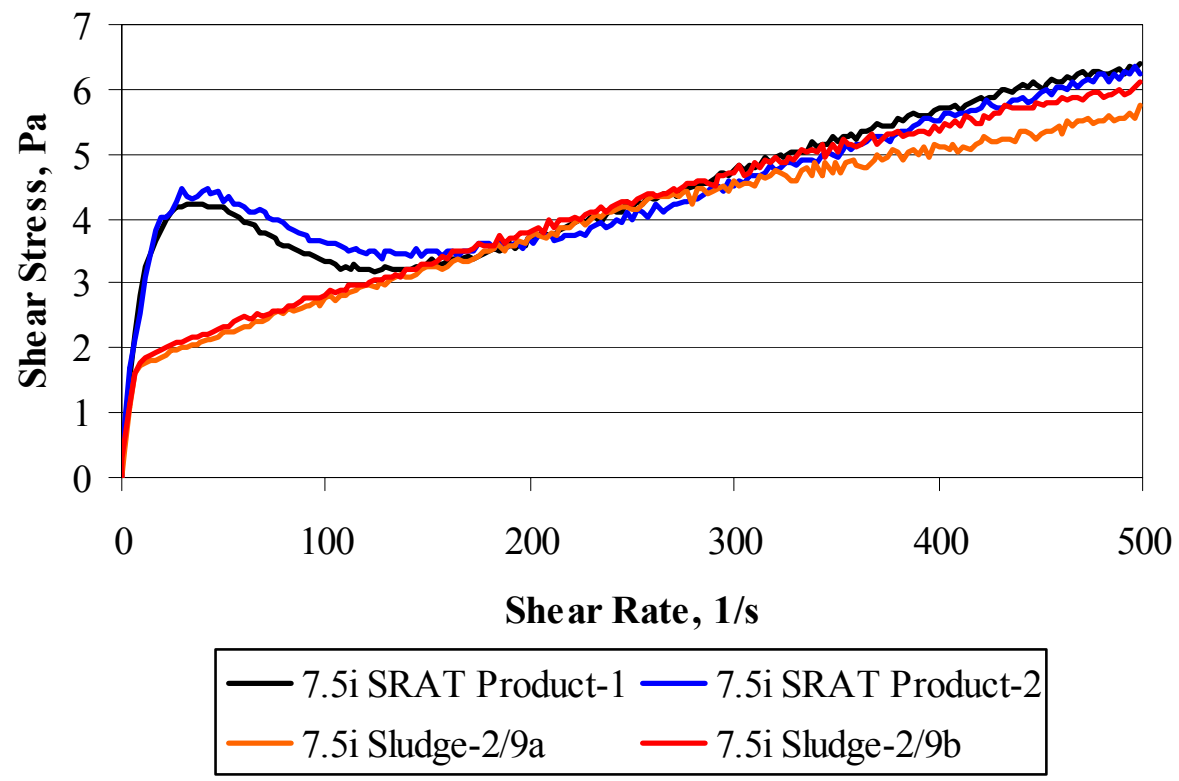

Figure 4-7. Impact of SRAT Processing, Batch 7.5i, Up Ramp Flow Curves

- The Batch 7.5ii SRAT product was nearly identical to the starting sludge except for a new hump in the up ramp portion of the flow curve (similar effect to that seen with Batch 7.5i, although all shear stress data was numerically greater). 


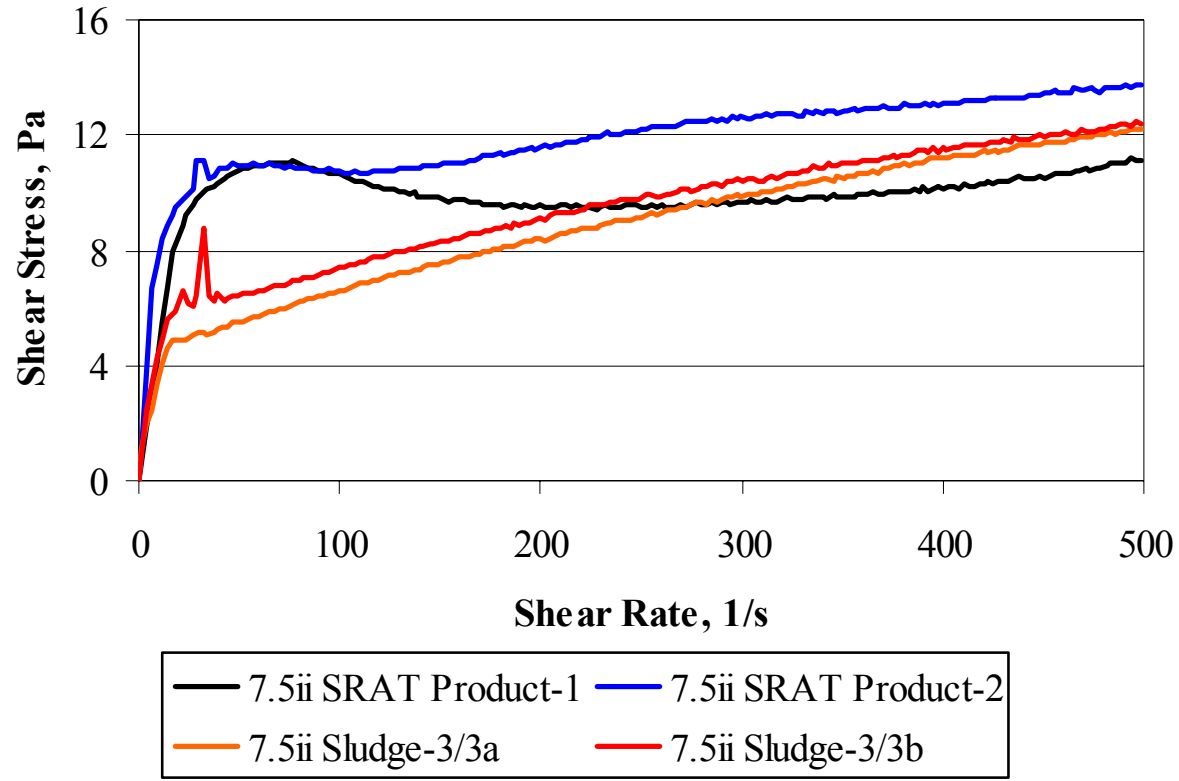

Figure 4-8. Impact of SRAT Processing, Batch 7.5ii, Up Ramp Flow Curves

- The Batch 11.25 SRAT product was considerably thicker than the starting sludge, and also developed a small hump in the up ramp portion of the flow curve.

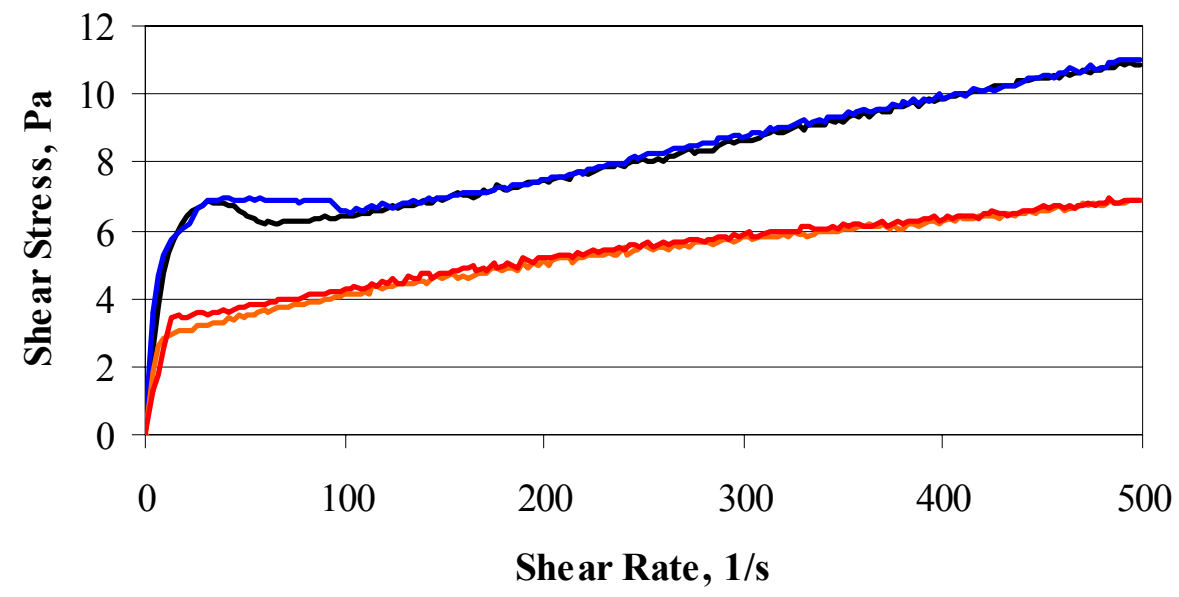

-11.25 SRAT Product- $1-11.25$ SRAT Product-2
-11.25 Sludge-2/26a -11.25 Sludge-2/26b

Figure 4-9. Impact of SRAT Processing, Batch 11.25, Up Ramp Flow Curves

- The hump in the Batch 15 sludge survived SRAT processing and was still present in the SRAT product. The SRAT product was considerably thicker, however, than the starting sludge. 
WSRC-TR-2004-00206

Revision 0

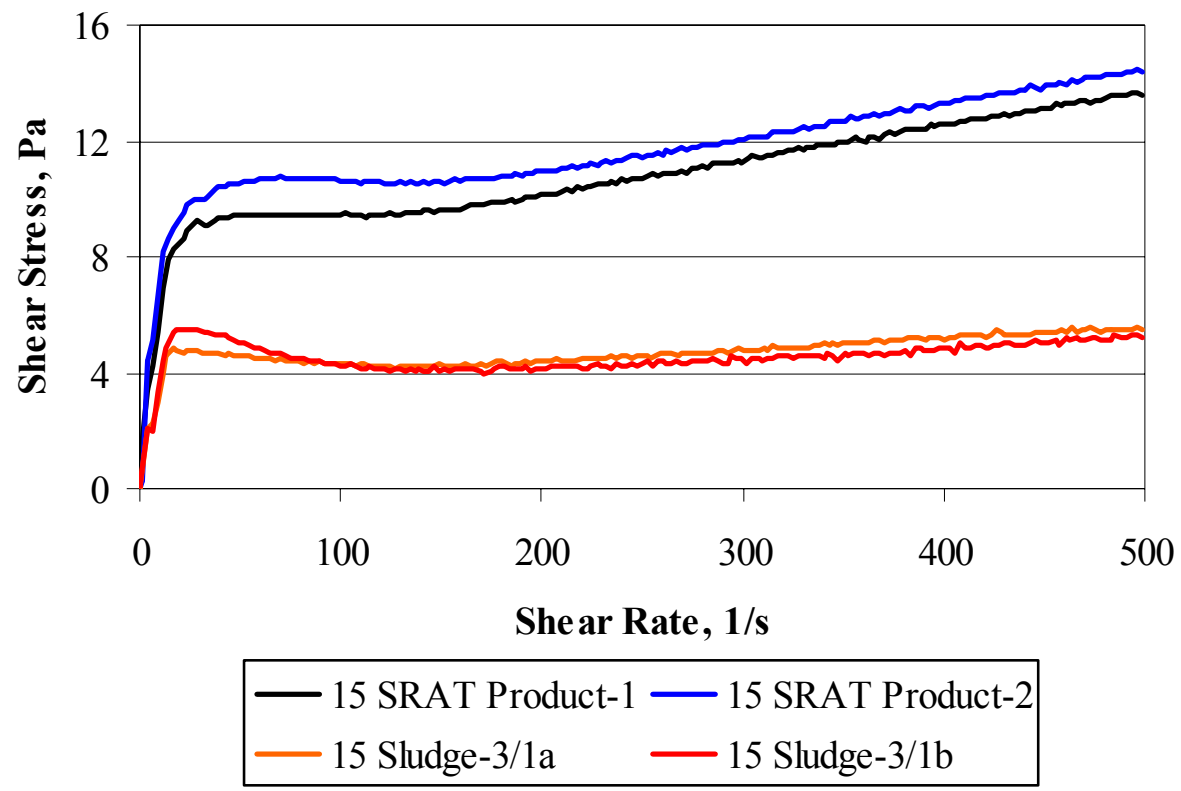

Figure 4-10. Impact of SRAT Processing, Batch 15, Up Ramp Flow Curves

The trend in most prior simulant work has been that the SRAT product was thinner than the starting sludge (implicit in this statement is that the volume of SRAT product is comparable to the volume of starting sludge in the SRAT). This was not observed in any of the six SRAT cycles with U performed as part of this program. Note, the non-uranium containing simulant was thinner, but this was believed to be due to the significantly lower $\mathrm{pH}$ of the SRAT product. One possibility is that there is a part of the simulant preparation process that thickens the simulant, but this thickening is somehow reversed in the SRAT cycle. In the case of these six in-house U simulants, perhaps the thickening process did not occur (since the sludge simulants were relatively thin), and the subsequent elimination of the thickening also did not occur (since the thickening never happened). There were obvious differences in scale and mixing between the SRNL simulant preparations and the historic simulant preparations at Optima, USCColumbia, and CETL that could be responsible. A current program is investigating some of these issues in simulant preparation. 


\subsection{CONCLUSIONS}

\subsection{SRAT Feeds and Products}

- Co-precipitation of $U$ during simulant sludge makeup results in the formation of Clarkeite, $\mathrm{Na}\left(\left(\mathrm{UO}_{2}\right) \mathrm{O}(\mathrm{OH})\right)$, a hydrated uranate containing $\mathrm{U}(\mathrm{VI})$, as the final uranium species. This same species has been identified in actual tank waste for SB2.

- There is no increase in calculated acid demand at room temperature as a result of increasing levels of $U$ in SRAT feed. Whether or not there is an impact on acid demand at elevated temperature or in the presence of mixed acids has not been addressed.

- Essentially no soluble U was found in the SRAT products with $\mathrm{pH}$ values above $\mathrm{pH}$ 6. This is consistent with observations from SRNL Shielded Cells SRAT cycles with SB2/3 blended waste $^{17}$ and SB3 waste $^{18}$ which did see soluble U in the SRAT products but which had final pH's below 6. Since DWPF operated SB2 processing at approximately $\mathrm{pH} 5.5$, they should have seen more soluble $\mathrm{U}$ and potentially thinner SRAT products.

- Different U species can be produced in the SRAT product suggesting the potential for some U redox activity. The primary species, $\mathrm{U}_{2} \mathrm{O}_{7}{ }^{2-}$ contained fully oxidized $\mathrm{U}(\mathrm{VI})$, while one product contained the mixed $\mathrm{U}$ oxidation state species $\mathrm{U}_{3} \mathrm{O}_{9}{ }^{2-}$. The impact of redox target on the SRAT product $\mathrm{U}$ species could not be addressed since only a single redox target was studied.

- XRD data suggests there was some dissolution and re-precipitation of $U$ as a result of SRAT processing since the SRAT product U-containing species were fine and not fully crystalline.

- SRAT vessel contents entrain gas and the volume increases during processing when the temperature is raised from 93 to $100{ }^{\circ} \mathrm{C}$, and the degree of expansion is greatest at the highest levels of $U$ (Batches 11.25 and 15).

\subsection{Rheology}

- All six sludges and seven SRAT products were thixotropic slurries, i.e. the apparent viscosity decreased with time under shear on a time scale of ten minutes. This produced down ramp flow curves that were always below the up ramp flow curves.

- The six sludges and seven SRAT products were generally pseudo-plastic slurries, i.e. the apparent viscosity decreased with increasing shear rate. There were some transient phenomena early in some of the up ramp flow curves during which this was not true.

- The six sludges and seven SRAT products were relatively thin and free-flowing slurries that when shaken vigorously did not retain any significant quantity of air bubbles.

- Rheological properties of the six new simulants were effectively independent of the time since preparation over a time scale of one to six weeks.

- The six new simulants had rheological properties that were bounded by those of the two Batch 7.5 preparations. This indicates that the impact of co-precipitated $U$ on rheology was no more significant than other variations in properties that occur during simulant preparation. 
- SRAT product samples showed more anomalous rheological behavior than the starting sludges. This was seen in the occurrence of more transient phenomena in the up ramp flow curves. There was also a greater spread in the rheological results for the seven SRAT products than for the six starting sludges. This indicated that SRAT processing had a variable impact on rheology.

- Both the SRAT product yield stress and consistency were found to increase with an increase in uranium concentration in a statistically significant manner.

- Transient phenomena (humps) in the up flow curves never re-occurred when a sample in the rheometer was run through a second up flow curve.

- The impact of SRAT processing on rheology was most apparent in the results for the Batch 11.25 and 15 slurries. These slurries thickened significantly during SRAT processing. SRAT products have generally been thinner than the starting sludges in previous work. 


\subsection{RECOMMENDATIONS/PATH FORWARD}

The impact of uranium on SRAT cycle processing, and ultimately DWPF processing issues such as airentrainment, has been studied. There does not appear to be a straightforward relationship between the level of uranium in the feed, at least to the degree we were able to isolate this contribution from other factors such as particle size, and the processing behavior of the sludge. There are still uncertainties related to uranium and the following recommendations may help address these issues.

- Evaluation of the impact of lower $\mathrm{pH}$ during the SRAT cycle on the uranium solubility in the SRAT product may help determine if a significant dissolution of uranium has an impact on the rheological properties of the material. This may help us gain a better understanding of the relationship between rheological behavior and plant operational issues.

- Based upon the uranium species produced in the SRAT product $\left(\mathrm{U}_{2} \mathrm{O}_{7}{ }^{2-}\right.$ and $\left.\mathrm{U}_{3} \mathrm{O}_{9}{ }^{2-}\right)$, it may be useful for melter operations to understand how the redox target (ratio of nitric acid to formic acid) impacts the uranium species formed during SRAT processing. A series of SRAT tests varying the acid ratios may address this issue.

- Evaluate the impact of particle size variations on the starting sludge rheology as well as the resulting SRAT product.

- Begin to characterize the tank waste for particle size distribution to develop an understanding of the impact of this parameter on processing behavior and assess the variability of this parameter in various samples received for qualification and study. Previous methods involving extremely high dilutions into unmatched matrices, i.e. water, for Microtrac analysis may alter the particle size of the sludge solids. Installation of a Lasentek instrument in the SRNL Shielded Cells would address this shortcoming.

- Characterize more actual tank waste solids and SRAT product solids produced from actual tank waste by XRD to develop a better understanding of the species present and formed as a result of processing. This information can then be related back to processing issues as they arise in the plant to help explain what may be causing any given issue.

- The scale of sludge makeup should be larger than the 1L scale used in this study. Samples taken for analyses prior to completion of each slurry represent too large a fraction of the total material and results in unnecessary variability.

- The scale of SRAT cycle simulations should be larger than $300 \mathrm{~g}$. At this level noble metal additions are miniscule and acid addition rates are very low leading to considerable variability and potential error. 
WSRC-TR-2004-00206

Revision 0

This page intentionally left blank. 


\subsection{REFERENCES}

${ }^{1}$ Patel, P. M. Technical Task Request, Investigation of Sludge Batch 2 Processing Issues in DWPF (U), HLW/DWPF/TTR-02-0035, Savannah River Site, Aiken, SC 29808 (2003).

${ }^{2}$ Bannochie, C. J. and Herman, D. T. Task Technical and Quality Assurance Plan - Determination of the Effect of Uranium Levels on Sludge Batch 2 Processing, WSRC-RP-2003-00314, Rev. 1, Savannah River Site, Aiken, SC 29808 (2003).

${ }^{3}$ Bannochie, C. J. Analytical Study Plan: Determination of the Effect of Uranium Levels on Sludge Batch 2 Processing, WSRC-RP-2003-00377, Rev. 1, Savannah River Site, Aiken, SC 29808 (2003).

${ }^{4}$ Fellinger, T. L., Pareizs, J. M., Bibler, N. E., Cozzi, A. D., and Crawford, C. L. Confirmation Run of the DWPF SRAT Cycle Using the Sludge-Only Flowsheet with Tank 40 Radioactive Sludge and Frit 200 in the Shielded Cells Facility, WSRC-TR-2002-00076, Savannah River Site, Aiken, SC 29808 (2002).

${ }^{5}$ Herman, D. T. and Wilmarth, W. R. Determination of the Effects of Uranium Levels on Sludge Batch 2 Processing, WSRC-TR-2003-00402, Rev. 0, Savannah River Site, Aiken, SC 29808 (2003).

${ }^{6}$ Hutson, N. D. Revision of Batch 1 Sludge Composition for Integrated Cold Runs in the Defense Waste Processing Facility, WSRC-TR-95-0079, Savannah River Site, Aiken, SC 29808 (1995).

${ }^{7}$ Baich, M. A. Documentation and Use of New Chemical Process Cell (CPC) Acid Calculation Spreadsheet, SRT-ITB-2003-00012, Rev. 0, Savannah River Site, Aiken, SC 29808 (Version 1/22/04).

${ }^{8}$ Stone, M. E. and McGrier, T. L. Impact of DWPF Processing Parameters on Rheology: Phase 1 Testing, WSRC-TR-2003-00364, Savannah River Site, Aiken, SC 29808 (2003).

${ }^{9}$ Jantzen, C. M., Koopman, D. C., Herman, C. C., Pickett, J. B., and Zamecnik, J. R. Electron Equivalence Model for Controlling REDuction/Oxidation (REDOX) Equilibrium During High Level Waste (HLW) Vitrification, WSRC-TR-2003-00126, Savannah River Site, Aiken, SC 29808 (2003).

${ }^{10}$ Bannochie, C. J. and Herman, D. T. Run Plan for the SB2 Simulant Containing 7.5 wt \% Uranium, SRT-GPD-2003-00065, Savannah River Site, Aiken, SC 29808 (2004).

${ }^{11}$ Bannochie, C. J. and Herman, D. T. Run Plan for the SB2 Simulant Containing 0 wt \% Uranium, SRTGPD-2004-00013, Savannah River Site, Aiken, SC 29808 (2004).

${ }^{12}$ Bannochie, C. J. and Herman, D. T. Run Plan for the SB2 Simulant Containing 3.75 wt \% Uranium, SRT-GPD-2004-00014, Savannah River Site, Aiken, SC 29808 (2004).

${ }^{13}$ Bannochie, C. J. and Herman, D. T. Run Plan for the SB2 Simulant Containing 7.5ii wt \% Uranium, SRT-GPD-2004-00015, Savannah River Site, Aiken, SC 29808 (2004).

${ }^{14}$ Bannochie, C. J. and Herman, D. T. Run Plan for the SB2 Simulant Containing 11.25 wt \% Uranium, SRT-GPD-2004-00016, Savannah River Site, Aiken, SC 29808 (2004). 
${ }^{15}$ Bannochie, C. J. and Herman, D. T. Run Plan for the SB2 Simulant Containing 15 wt \% Uranium, SRT-GPD-2004-00017, Savannah River Site, Aiken, SC 29808 (2004).

${ }^{16}$ Stone, M. E. TTQAP: DWPF Air Entrainment and Heat Transfer Simulation and Mitigation, WSRC-RP-2003-00287, Rev. 1, Savannah River Site, Aiken, SC 29808 (2004).

${ }^{17}$ Bannochie, C. J., Pareizs, J. M., and Koopman, D. C. Sludge Batch 2/3 Blend SRAT Cycle in the SRNL Shielded Cells, WSRC-TR-2004-00097, Savannah River Site, Aiken, SC 29808 (2004).

${ }^{18}$ Pareizs, J. M., Koopman, D. C., Click, D. R., Cozzi, A. D., and Bibler, N. E. Sludge Batch 3 Qualification in the SRTC Shielded Cells, WSRC-TR-2004-00050, Savannah River Site, Aiken, CS 29808 (2004). 


\subsection{ACKNOWLEDGEMENTS}

The authors would like to acknowledge the support of ITS technicians John Duvall, Sarah Brown, Irene Reamer, Phyllis Workman, and Sammie King for efforts conducting the numerous SRAT cycles and characterizations, Debbie Marsh for assistance in preparing the sludge materials and rheology measurements; Sherry Vissage for calibration of the SRAT decanter and with rheology measurements; and the SRNL Mobile Laboratory's David Best, Pat Toole, and Jennifer Jansen for all their efforts on sample analyses. We also thank Art Jurgensen (ADS) for helpful discussions on XRD data and Carol Jantzen for insight into melter operations. 
WSRC-TR-2004-00206

Revision 0

This page intentionally left blank. 
WSRC-TR-2004-00206

Revision 0

\section{APPENDIX A. SAMPLE SIMULANT MAKEUP PROCEDURE}




\section{Uranium Sludge Batch 2 Preparation}

Date:

Activity:

Researcher:

Manager:

Technician:
December 9, 2003

LWIIBSF04

C. J. Bannochie, 774-42A, 151 / Dave Herman, 735-11A, 119

S. L. Marra

John Duvall / Debbie Marsh / Sarah Brown

\section{0 - Introduction:}

These instructions are for the preparation of DWPF sludge batch 2 simulant with $7.5 \mathrm{wt} \%$ uranium.

\section{0 - Objectives:}

Prepare a sludge solution

\section{0 - Safety}

Don lab coat and gloves. Work will involve using $50 \mathrm{wt} \% \mathrm{NaOH}$. Care should be taken when adding this solution to the bulk solution. This addition will be a neutralization and should be completed in a hood. This addition should take place slowly.

\section{0 - Waste Disposal}

Any waste produced as part of this work may be hazardous. $\mathrm{pH}$ of the solution should be adjusted to 2-4 before disposal in the HLW drainage system.

\section{0 - Sludge Preparation}

5.1 Obtain the following chemicals. Record the M\&TE identifier for the balance and weight set used.

\begin{tabular}{|l|l|l|l|l|}
\hline Component & FW & Mass (g) & Mass Used & Manufacturer \& Lot \# \\
\hline $\mathrm{Mn}\left(\mathrm{NO}_{3}\right)_{2}[50 \mathrm{wt} \%]$ & & 22.164 & & \\
\hline $\mathrm{NaOH}[50 \mathrm{wt} \%]$ & & 252.575 & & \\
\hline $\mathrm{KMnO}$ & & 6.529 & & \\
\hline $\mathrm{Fe}\left(\mathrm{NO}_{3}\right)_{3} \cdot 9 \mathrm{H}_{2} \mathrm{O}$ & 404.02 & 403.695 & & \\
\hline $\mathrm{Ni}\left(\mathrm{NO}_{3}\right)_{2} \cdot 6 \mathrm{H}_{2} \mathrm{O}$ & 290.81 & 15.901 & & \\
\hline $\mathrm{UO}_{2}\left(\mathrm{NO}_{3}\right)_{2} \cdot 6 \mathrm{H}_{2} \mathrm{O}$ & 502.146 & 41.275 & & \\
\hline $\mathrm{CaCO}_{3}$ & $\mathrm{NA}$ & zero & NA & \\
\hline
\end{tabular}

See Instructions below $(5.2-5.11)$ for preparation of above reagents.

List continued on the page 4 . 
$5.2 \quad$ Prepare $252.575 \mathrm{~g}$ of $50 \mathrm{wt} \% \mathrm{NaOH}$. Mix $126.288 \mathrm{~g}$ of $\mathrm{NaOH}$ with $126.275 \mathrm{~g}$ of water.

5.3 Prepare $10.8 \mathrm{~L}$ of $\mathrm{pH} 10.5$ water $( \pm 0.5 \mathrm{pH}$ unit) (use $0.134 \mathrm{~g}$ $\mathrm{NaOH})$.

$5.4 \quad$ Mix $22.164 \mathrm{~g}$ of $50 \mathrm{wt} \% \mathrm{Mn}\left(\mathrm{NO}_{3}\right)_{2}$ with $165.090 \mathrm{~g}$ of water in a $6 \overline{\mathrm{L} \text { water jacketed preparation vessel. Adjust the temperature to } 35}$ to $40{ }^{\circ} \mathrm{C}$. Solution is to be stirred continuously.

Label: Solution 1

5.5 In a separate vessel, dissolve $6.529 \mathrm{~g}$ of $\mathrm{KMnO}_{4}$ in $227.043 \mathrm{~g}$ of water. When the permanganate has dissolved, adjust solution temperature to between 35 to $40^{\circ} \mathrm{C}$.

Label: Solution 2

5.6 Add Solution 2 to Solution 1 slowly over 1 hour - Maintain temperature at 35 to $40{ }^{\circ} \mathrm{C}$.

5.7 Dissolve $403.695 \mathrm{~g}$ $\mathrm{Fe}\left(\mathrm{NO}_{3}\right)_{3} \cdot 9 \mathrm{H}_{2} \mathrm{O}$ in $442.341 \mathrm{~g}$ of water.

$\overline{\text { Label: Solution } 3}$

5.8 Slowly add Solution 3 to Solution 1. Maintain temperature at 35 to $40{ }^{\circ} \mathrm{C}$.

$5.9 \quad$ Add $15.901 \mathrm{~g}$ of $\mathrm{Ni}\left(\mathrm{NO}_{3}\right)_{2} \cdot 6 \mathrm{H}_{2} \mathrm{O}$ to Solution 1. Mix for at least 15 minutes.

$5.10 \quad$ Add $41.275 \mathrm{~g}$ of $\mathrm{UO}_{2}\left(\mathrm{NO}_{3}\right)_{2} \cdot 6 \mathrm{H}_{2} \mathrm{O}$ to Solution 1. Mix for at least 15 minutes.

$5.11 \quad$ In a separate vessel add $252.575 \mathrm{~g}$ $42.898 \mathrm{~g}$ of water. of $50 \% \mathrm{NaOH}$ solution to

5.12 Increase agitation to $600 \mathrm{rpm}$.

5.13 Slowly add the caustic solution to Solution 1, keeping the temperature between 35 and $40{ }^{\circ} \mathrm{C}$. This step should be done with continuous agitation in a hood.

5.14 Measure $\mathrm{pH}$ of aqueous fraction, adjust to $\geq 10.5$ (if already $>10.5$, take no action).

5.15 Continue agitation for 30 minutes following final chemical addition. 
5.16 Pump the sludge from the jacketed preparation vessel in to a settling bottle, set aside. Allow Solution 1 to settle for 12 hours (or longer). Remove aqueous phase and discard.

5.17 Add 3.6 L pH 10.5 adjusted water to Solution 1. Agitate for 30 minutes.

5.18 Allow Solution 1 to settle for 12 hours (or longer). Remove aqueous phase and discard.

5.19 Measure $\mathrm{pH}$, adjust to $\geq 10.5$ (if already $>10.5$, take no action).

5.20 Add 3.6 L pH 10.5 adjusted water to Solution 1. Agitate for 30 minutes.

5.21 Allow Solution 1 to settle for 12 hours (or longer). Remove aqueous phase and discard.

5.22 Measure $\mathrm{pH}$, adjust to $\geq 10.5$ (if already $>10.5$, take no action).

5.23 Add 3.6 L pH 10.5 adjusted water to Solution 1. Agitate for 30 minutes.

5.24 Allow Solution 1 to settle for 12 hours (or longer). Remove aqueous phase and discard.

5.25 Measure $\mathrm{pH}$, adjust to $\geq 10.5$ (if already $>10.5$, take no action).

5.26 Confirm soluble solids concentration in the aqueous fraction of the slurry is between $0.15-0.20 \mathrm{wt} \%$.

5.27 Determine concentration of Fe, Mn, and Ni in sludge solids and concentration of $\mathrm{Na}$ in supernatant liquid by ICP-AES.

5.28 Add all remaining chemicals. Each chemical is to be added separately with at least 15 minutes between additions.

NOTE: The following reagent concentrations need to be adjusted based on the size of the sample removed for analyses listed in 5.26 and 5.27. See researcher for adjustment calculation prior to preparing these reagents. 
WSRC-TR-2004-00206

Revision 0

\begin{tabular}{|c|c|c|c|c|c|}
\hline Component $^{\dagger}$ & FW & Mass (g) & Adj. Mass(g) & Mass Used & $\begin{array}{l}\text { Manufacturer } \\
\text { \& Lot \# }\end{array}$ \\
\hline $\begin{array}{l}\mathrm{Al}(\mathrm{OH})_{3} \bullet \mathrm{nH}_{2} \mathrm{O} \\
{[32-35 \mathrm{wt} \% \text { water }]^{*}}\end{array}$ & & 74.855 & & & \\
\hline $\mathrm{BaSO}_{4}$ & 233.40 & 0.778 & & & \\
\hline $1.5 \mathrm{Ca}_{3}\left(\mathrm{PO}_{4}\right)_{2} \cdot 0.5 \mathrm{Ca}(\mathrm{OH})_{2}{ }^{*}$ & 502.32 & 0.456 & & & \\
\hline $\mathrm{CaCO}_{3}$ & 100.09 & 11.360 & & & \\
\hline $\mathrm{CaSO}_{4}$ [anhydrous] ${ }^{*}$ & 136.15 & 1.205 & & & \\
\hline $\mathrm{Cr}_{2} \mathrm{O}_{3}$ & 151.99 & 0.715 & & & \\
\hline $\mathrm{CsNO}_{3}$ & NA & zero & & NA & \\
\hline $\mathrm{CuO}$ & 79.54 & 0.366 & & & \\
\hline $\mathrm{KNO}_{3}$ & 101.10 & 0.352 & & & \\
\hline $\mathrm{KOH}$ & NA & zero & & NA & \\
\hline $\mathrm{MgO}$ & 40.31 & 0.438 & & & \\
\hline $\mathrm{Na}_{2} \mathrm{CO}_{3}$ & 124.00 & 4.767 & & & \\
\hline $\mathrm{Na}_{2} \mathrm{SO}_{4}$ & 142.04 & 0.666 & & & \\
\hline $\mathrm{Na}_{3} \mathrm{PO}_{4} \cdot 12 \mathrm{H}_{2} \mathrm{O}$ & 380.12 & 0.408 & & & \\
\hline $\mathrm{NaCl}$ & 58.44 & 4.672 & & & \\
\hline $\mathrm{NaF}$ & 41.99 & 0.078 & & & \\
\hline $\mathrm{NaI}$ & 149.89 & 0.079 & & & \\
\hline $\mathrm{NaNO}_{2}$ & 69.00 & 16.467 & & & \\
\hline $\mathrm{NaNO}_{3}$ & 84.99 & 5.947 & & & \\
\hline $\mathrm{NaOH}$ & 40.00 & 9.681 & & & \\
\hline $\mathrm{Nd}_{2} \mathrm{O}_{3}$ & NA & zero & & NA & \\
\hline $\mathrm{PbSO}_{4}$ & 303.25 & 0.822 & & & \\
\hline $\mathrm{SiO}_{2}$ & 60.09 & 3.746 & & & \\
\hline $\mathrm{SrCO}_{3}$ & 147.63 & 0.273 & & & \\
\hline Zeolite & NA & Zero & & NA & \\
\hline $\mathrm{ZnO}$ & 81.37 & 0.742 & & & \\
\hline$\overline{\mathrm{ZrO}_{2}}$ & 123.22 & 1.479 & & & \\
\hline
\end{tabular}

* specified mass assumes given component, if hydration level or other change occurs, mass needed must be recalculated.

${ }^{\dagger}$ particle size must be less than $40 \mu \mathrm{m}$

5.29 Agitate for 1 hour.

5.30 Determine wt \% solids in triplicate using $5 \mathrm{~g}$ samples. Submit sample for total cationic and anionic analysis. 
WSRC-TR-2004-00206

Revision 0

\begin{tabular}{|l|l|l|l|}
\hline & \multicolumn{3}{|c|}{ Sludge Batch 2 Simulant } \\
\hline Filter Paper mass $(\mathrm{g})$ & & & \\
\hline g of sludge & & & \\
\hline Dried $\left(115^{\circ} \mathrm{C}\right)$ filter paper \& sludge & & & \\
\hline Wt. of dried sludge & & & \\
\hline Wt \% solids & & & \\
\hline
\end{tabular}

5.30.1 Weigh a filter paper.

5.30.2 Filter a $5.00 \mathrm{~mL}$ sample.

5.30.3 Wash filtered sample with water. Discard wash water.

5.30.4 Dry sample overnight at $\sim 115^{\circ} \mathrm{C}$.

5.30.5 Weigh dried filter paper.

5.31 Store and label: DWPF Sludge Batch 2 Simulant w/ 7.5 wt \% uranium.

\section{0 - Housekeeping}

Restore area to acceptable housekeeping standards.

\section{0 - Documentation}

Initial Instructions and return completed copy for placement in the Laboratory notebook. 
WSRC-TR-2004-00206

Revision 0

\section{APPENDIX B. SIMULANT RECIPES}


WSRC-TR-2004-00206

Revision 0

Table B- 1. Recipe Calculation for 0 wt \% Uranium Sludge Batch 2 Simulant

Recipe for Tank $40+$ Tank 8 Blend

For 1.2 liter batch sludge simulant

Keyed to [2]-rev. for Bannochie, 11/2003 (solids boosted x

$1.16)$

\begin{tabular}{|c|c|c|}
\hline$[\mathrm{A}]$ & $25.172 \mathrm{gms}$ & $50 \% \mathrm{Mn}\left(\mathrm{NO}_{3}\right)_{2}$ \\
\hline [B] & $187.495 \mathrm{~mL}$ & Water \\
\hline [C] & $7.415 \mathrm{gms}$ & $\mathrm{KMnO}_{4}$ \\
\hline [D] & $257.857 \mathrm{~mL}$ & Water \\
\hline [E] & $55.680 \mathrm{~mL}$ & Water \\
\hline$[\mathrm{F}]$ & $905.179 \mathrm{gms}$ & $7 \% \mathrm{Fe}$ as Ferric Nitrate \\
\hline [G] & $18.059 \mathrm{gms}$ & $\mathrm{Ni}\left(\mathrm{NO}_{3}\right)_{2} 6 \mathrm{H}_{2} \mathrm{O}$ \\
\hline$[\mathrm{H}]$ & $286.294 \mathrm{gms}$ & $50 \% \mathrm{NaOH}$ \\
\hline [l] & $48.720 \mathrm{~mL}$ & Water \\
\hline [J] & $0.000 \mathrm{gms}$ & $\mathrm{CaCO}_{3}$ \\
\hline
\end{tabular}

This converts to these solids (iron phase must be guessed)

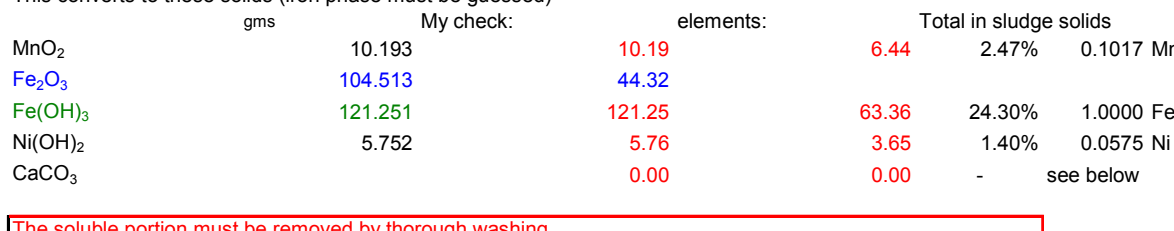

The soluble portion must be removed by thorough washing.

Phase 4

Chemicals

Chemicals gms

$\mathrm{Al} \mathrm{OH}_{3}$

$\mathrm{Ca}_{3}(\mathrm{PO} 4)_{2}$

$\mathrm{CaCO}_{3}$

$\mathrm{CaSO}_{4}$

$\mathrm{Cr}_{2} \mathrm{O}_{3}$

$\mathrm{CsNO}_{3}$

$\mathrm{CuO}$

$\mathrm{KNO}_{3}$

$\mathrm{KOH}$

$\mathrm{MgO}$

$\mathrm{Na}_{2} \mathrm{CO}_{3}$

$\mathrm{Na}_{2} \mathrm{SO}_{4}$

$\mathrm{Na}_{3} \mathrm{PO}_{4}$

$\mathrm{NaCl}$

$\mathrm{NaF}$

$\mathrm{Nal}$

$\mathrm{NaNO}_{2}$

$\mathrm{NaNO}_{3}$

$\mathrm{NaOH}$

$\mathrm{PbSO}_{4}$

$\mathrm{SiO}_{2}$

$\mathrm{SrCO}_{3}$

Zeolite

$\mathrm{ZnO}$

$\mathrm{ZrO}_{2}$

55.260

55.260

0.884
0.479

12.902

1.368

0.812

0.000

0.416

0.399

0.000

0.498

4.767

0.666

0.176

4.672

0.078

0.079

16.467

5.947

9.681

0.000

0.934

4.254

0.310

0.000

0.843

$1.679-0.84$

260.77 gms. (using $\left.\mathrm{Fe}(\mathrm{OH})_{3}\right)$

$\begin{array}{rrrl}55.26 & 19.114 & 7.33 \% & 0.3017 \mathrm{Al} \\ 0.88 & 0.520 & 0.20 \% & 0.0082 \mathrm{Ba} \\ 0.48 & 5.755 & 2.21 \% & 0.0908 \text { total Ca } \\ 12.90 & & & \\ 1.37 & & & \\ 0.81 & 0.556 & 0.21 \% & 0.0088 \mathrm{Cr} \\ 0.00 & & & \\ 0.42 & 0.332 & 0.13 \% & 0.0052 \mathrm{Cu} \\ 0.40 & 0.154 & 0.06 \% & 0.0024 \mathrm{~K} \\ 0.00 & & & \\ 0.50 & 0.300 & 0.12 \% & 0.0047 \mathrm{Mg} \\ 4.77 & 16.910 & 6.48 \% & 0.2669 \text { total Na} \\ 0.67 & & & \end{array}$

Dry Solids Includes Sludge + Supernate.

$19.6 \%$ Total Solids

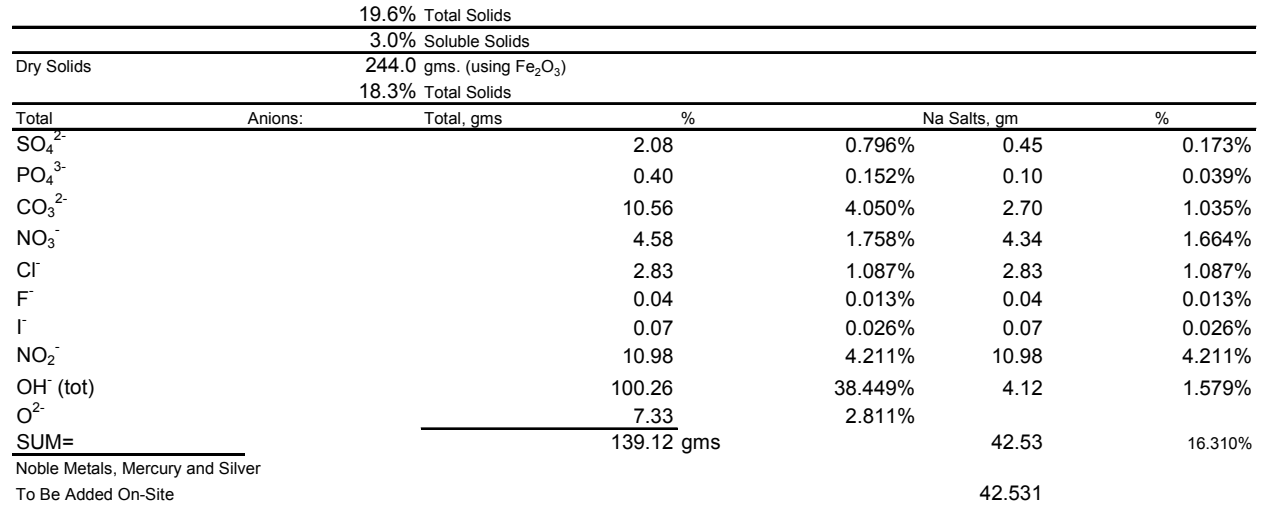


WSRC-TR-2004-00206

Revision 0

Table B- 2. Recipe Calculation for $3.75 \mathrm{wt} \%$ Uranium Sludge Batch 2 Simulant

\begin{tabular}{|c|c|c|c|c|c|}
\hline \multicolumn{6}{|c|}{ Recipe for Tank $40+$ Tank 8 Blend } \\
\hline \multicolumn{5}{|c|}{$\begin{array}{l}\text { Keyed to [2]-rev. for Bannochie, } 11 / 2003 \text { (solids boosted } x \\
\text { reduce insolubles for } \mathrm{U} \text { incorporation, constant } \mathrm{Na}\end{array}$} & \multirow[t]{2}{*}{$\begin{array}{l}1.16) \\
0.94\end{array}$} \\
\hline Phase 1 & & & & & \\
\hline$[\mathrm{A}]$ & \multicolumn{2}{|c|}{$23.662 \mathrm{gms}$} & \multicolumn{3}{|c|}{$50 \% \mathrm{Mn}\left(\mathrm{NO}_{3}\right)_{2}$ in water } \\
\hline [B] & \multicolumn{2}{|c|}{$176.246 \mathrm{~mL}$} & \multicolumn{3}{|c|}{ Water } \\
\hline [C] & \multicolumn{2}{|c|}{$6.970 \mathrm{gms}$} & \multicolumn{3}{|l|}{$\mathrm{KMnO}_{4}$} \\
\hline [D] & \multicolumn{2}{|c|}{$242.386 \mathrm{~mL}$} & \multicolumn{3}{|l|}{ Water } \\
\hline [E] & \multirow{2}{*}{\multicolumn{2}{|c|}{$\begin{array}{c}52.339 \mathrm{~mL} \\
850.868 \mathrm{gms}\end{array}$}} & \multicolumn{3}{|l|}{ Water } \\
\hline [F] & & & \multicolumn{3}{|c|}{$7 \% \mathrm{Fe}$ as Ferric Nitrate in water } \\
\hline [G] & \multicolumn{2}{|c|}{$16.976 \mathrm{gms}$} & \multicolumn{3}{|c|}{$\mathrm{Ni}\left(\mathrm{NO}_{3}\right)_{2} \cdot 6 \mathrm{H}_{2} \mathrm{O}$} \\
\hline$[-]$ & \multicolumn{2}{|c|}{$16.200 \mathrm{gms}$} & \multicolumn{3}{|l|}{$\mathrm{UO}_{2}\left(\mathrm{NO}_{3}\right)_{2}$} \\
\hline$[\mathrm{H}]$ & \multicolumn{2}{|c|}{$269.363 \mathrm{gms}$} & \multicolumn{3}{|c|}{$50 \% \mathrm{NaOH}$ in water } \\
\hline [I] & \multicolumn{2}{|c|}{$45.797 \mathrm{~mL}$} & \multicolumn{3}{|c|}{ Water } \\
\hline$[\mathrm{J}]$ & \multicolumn{2}{|c|}{$0.000 \mathrm{gms}$} & \multicolumn{3}{|l|}{$\mathrm{CaCO}_{3}$} \\
\hline \multicolumn{6}{|c|}{ This converts to these solids (iron phase must be guessed) } \\
\hline & \multicolumn{2}{|c|}{ gms $\quad$ My check: } & elements: & \multicolumn{2}{|c|}{ Total in sludge solids } \\
\hline $\mathrm{MnO}_{2}$ & 9.582 & 9.58 & 6.06 & $2.32 \%$ & $0.1017 \mathrm{Mn}$ \\
\hline $\mathrm{Fe}_{2} \mathrm{O}_{3}$ & 98.242 & 41.66 & & & \\
\hline $\mathrm{Fe}(\mathrm{OH})_{3}$ & 113.976 & 113.98 & 59.56 & $22.85 \%$ & $1.0000 \mathrm{Fe}$ \\
\hline $\mathrm{Ni}(\mathrm{OH})_{2}$ & 5.407 & 5.41 & 3.43 & $1.31 \%$ & $0.0575 \mathrm{Ni}$ \\
\hline $\mathrm{Na}_{2} \mathrm{U}_{2} \mathrm{O}_{7}$ & 13.035 & 13.04 & 9.79 & $3.75 \%$ & $0.1643 \mathrm{U}$ \\
\hline $\mathrm{CaCO}_{3}$ & & 0.00 & 0.00 & - & see below \\
\hline
\end{tabular}

Phase 4

\begin{tabular}{|c|c|c|c|c|c|}
\hline Chemicals & gms & & & & \\
\hline $\mathrm{Al}(\mathrm{OH})_{3}$ & 51.944 & 51.94 & 17.968 & $6.89 \%$ & $0.3017 \mathrm{Al}$ \\
\hline $\mathrm{BaSO}_{4}$ & 0.831 & 0.83 & 0.489 & $0.19 \%$ & $0.0082 \mathrm{Ba}$ \\
\hline $\mathrm{Ca}_{3}(\mathrm{PO} 4)_{2}$ & 0.451 & 0.45 & 5.410 & $2.08 \%$ & 0.0908 total $\mathrm{Ca}$ \\
\hline $\mathrm{CaCO}_{3}$ & 12.128 & 12.13 & & & \\
\hline $\mathrm{CaSO}_{4}$ & 1.286 & 1.29 & & & \\
\hline $\mathrm{Cr}_{2} \mathrm{O}_{3}$ & 0.763 & 0.76 & 0.522 & $0.20 \%$ & $0.0088 \mathrm{Cr}$ \\
\hline $\mathrm{CsNO}_{3}$ & 0.000 & 0.00 & & & \\
\hline $\mathrm{CuO}$ & 0.391 & 0.39 & 0.312 & $0.12 \%$ & $0.0052 \mathrm{Cu}$ \\
\hline $\mathrm{KNO}_{3}$ & 0.375 & 0.38 & 0.145 & $0.06 \%$ & $0.0024 \mathrm{~K}$ \\
\hline $\begin{array}{l}\mathrm{KOH} \\
\mathrm{MgO}\end{array}$ & $\begin{array}{l}0.000 \\
0.468\end{array}$ & $\begin{array}{l}0.00 \\
0.47\end{array}$ & & $0.11 \%$ & \\
\hline $\mathrm{Na}_{2} \mathrm{CO}_{3}$ & 4.767 & 4.77 & 16.910 & $6.49 \%$ & 0.2839 total $\mathrm{Na}$ \\
\hline $\mathrm{Na}_{2} \mathrm{SO}_{4}$ & 0.666 & 0.67 & & $6.85 \%$ & $0.2998 \mathrm{Na}+\mathrm{U} . \mathrm{Na}$ \\
\hline $\mathrm{Na}_{3} \mathrm{PO}_{4}$ & 0.176 & 0.18 & & & \\
\hline $\mathrm{NaCl}$ & 4.672 & 4.67 & & & \\
\hline $\mathrm{NaF}$ & 0.078 & 0.08 & & & \\
\hline Nal & 0.079 & 0.08 & & & \\
\hline $\mathrm{NaNO}_{2}$ & 16.467 & 16.47 & & & \\
\hline $\mathrm{NaNO}_{3}$ & 5.947 & 5.95 & & & \\
\hline $\mathrm{NaOH}$ & 9.681 & 9.68 & & & \\
\hline $\mathrm{Nd}_{2} \mathrm{O}_{3}$ & 0.000 & 0.00 & & & \\
\hline $\mathrm{PbSO}_{4}$ & 0.878 & 0.88 & 0.600 & $0.23 \%$ & $0.0101 \mathrm{~Pb}$ \\
\hline $\mathrm{SiO}_{2}$ & 3.999 & 4.00 & 1.869 & $0.72 \%$ & $0.0314 \mathrm{Si}$ \\
\hline $\mathrm{SrCO}_{3}$ & 0.292 & 0.29 & 0.173 & $0.07 \%$ & $0.0029 \mathrm{Sr}$ \\
\hline Zeolite & 0.000 & 0.00 & & & \\
\hline $\mathrm{ZnO}$ & 0.792 & 0.79 & 0.636 & $0.24 \%$ & $0.0107 \mathrm{Zn}$ \\
\hline \multirow[t]{2}{*}{$\mathrm{ZrO}_{2}$} & 1.578 & 1.58 & 1.169 & $0.45 \%$ & $0.0196 \mathrm{Zr}$ \\
\hline & \multicolumn{5}{|c|}{260.71 gms. (using $\mathrm{Fe}(\mathrm{OH})_{3}$ ) } \\
\hline
\end{tabular}

\begin{tabular}{ll}
260.71 gms. (using Fe(OH $\left.)_{3}\right)$ \\
\hline Dry Solids $\quad 260.7$ Includes Sludge + Supern
\end{tabular}

Sludge Solids

$2.6 \%$ Total Solids

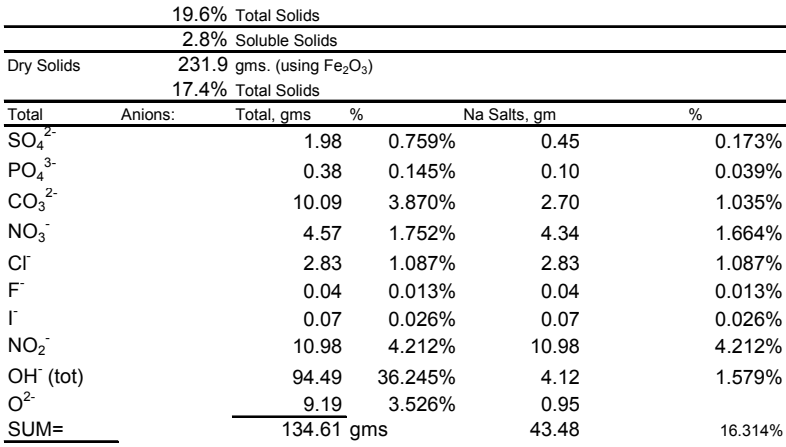

Noble Metals, Mercury and Silver

To Be Added On-Site 
WSRC-TR-2004-00206

Revision 0

Table B- 3. Recipe Calculation for 7.5 wt \% Uranium Sludge Batch 2 Simulant

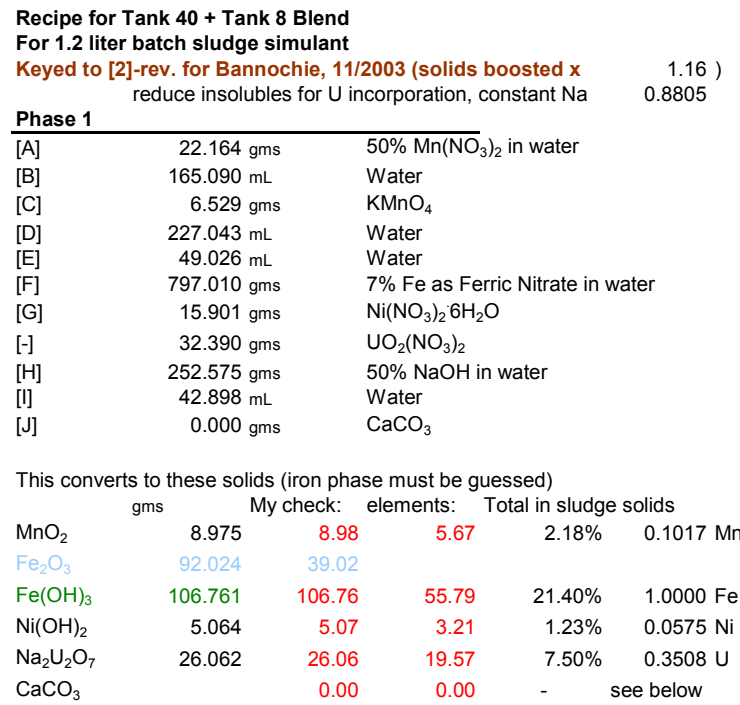

The soluble portion must be removed by thorough washing.

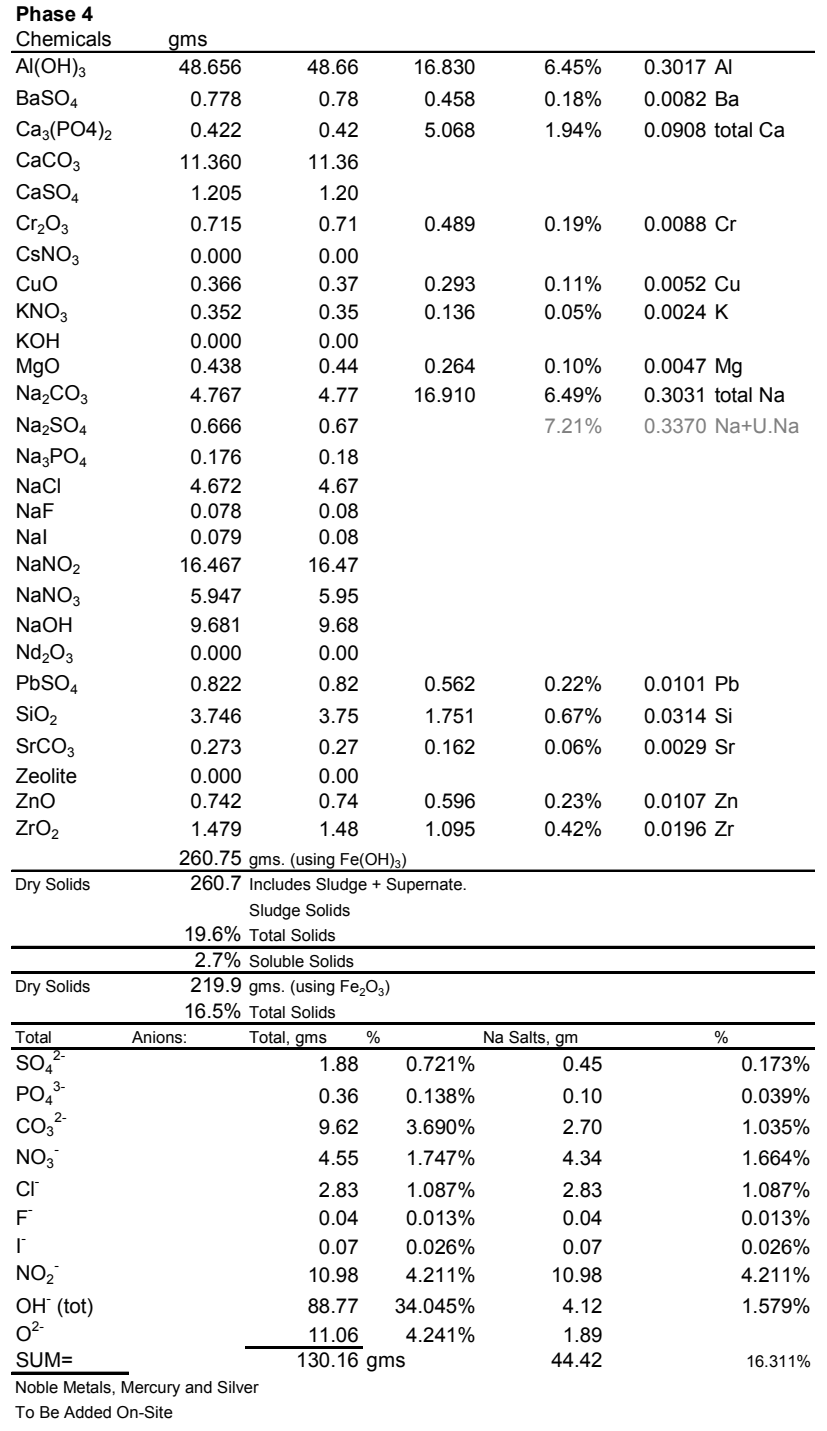


WSRC-TR-2004-00206

Revision 0

Table B- 4. Recipe Calculation for 11.25 wt \% Uranium Sludge Batch 2 Simulant

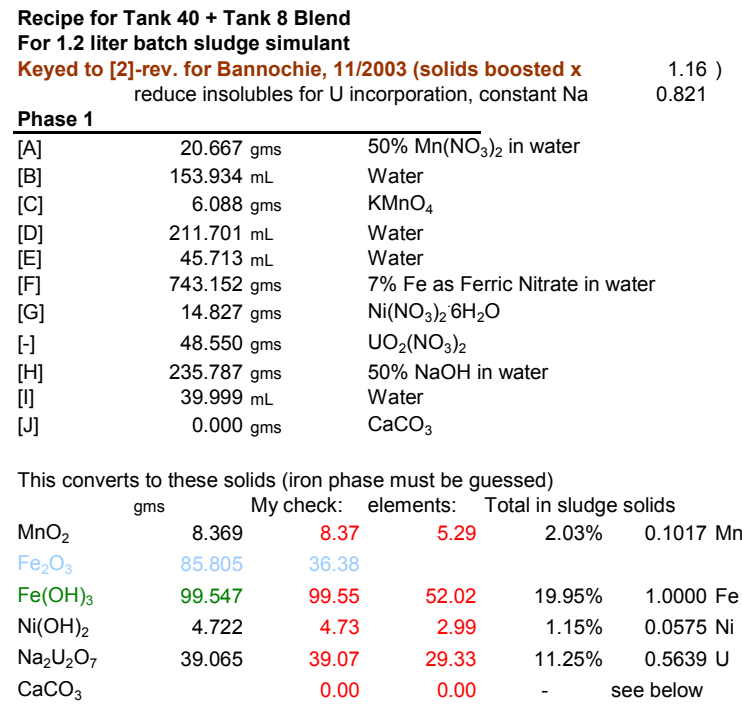

The soluble portion must be removed by thorough washing.

\begin{tabular}{|c|c|c|c|c|c|}
\hline $\begin{array}{l}\text { Phase } 4 \\
\text { Chemicals }\end{array}$ & gms & & & & \\
\hline $\mathrm{Al}(\mathrm{OH})_{3}$ & 45.368 & 45.37 & 15.693 & $6.02 \%$ & $0.3017 \mathrm{Al}$ \\
\hline $\mathrm{BaSO}_{4}$ & 0.725 & 0.73 & 0.427 & $0.16 \%$ & $0.0082 \mathrm{Ba}$ \\
\hline $\mathrm{Ca}_{3}(\mathrm{PO} 4)_{2}$ & 0.394 & 0.39 & 4.725 & $1.81 \%$ & 0.0908 total $\mathrm{Ca}$ \\
\hline $\mathrm{CaCO}_{3}$ & 10.593 & 10.59 & & & \\
\hline $\mathrm{CaSO}_{4}$ & 1.123 & 1.12 & & & \\
\hline $\mathrm{Cr}_{2} \mathrm{O}_{3}$ & 0.667 & 0.67 & 0.456 & $0.17 \%$ & $0.0088 \mathrm{Cr}$ \\
\hline $\mathrm{CsNO}_{3}$ & 0.000 & 0.00 & & & \\
\hline $\mathrm{CuO}$ & 0.342 & 0.34 & 0.273 & $0.10 \%$ & $0.0052 \mathrm{Cu}$ \\
\hline $\mathrm{KNO}_{3}$ & 0.328 & 0.33 & 0.127 & $0.05 \%$ & $0.0024 \mathrm{~K}$ \\
\hline $\mathrm{KOH}$ & 0.000 & 0.00 & & & \\
\hline $\mathrm{MgO}$ & 0.408 & 0.41 & 0.246 & $0.09 \%$ & $0.0047 \mathrm{Mg}$ \\
\hline $\mathrm{Na}_{2} \mathrm{CO}_{3}$ & 4.767 & 4.77 & 16.910 & $6.48 \%$ & 0.3251 total $\mathrm{Na}$ \\
\hline $\mathrm{Na}_{2} \mathrm{SO}_{4}$ & 0.666 & 0.67 & & $7.57 \%$ & $0.3795 \mathrm{Na}+\mathrm{U} . \mathrm{Na}$ \\
\hline $\mathrm{Na}_{3} \mathrm{PO}_{4}$ & 0.176 & 0.18 & & & \\
\hline $\mathrm{NaCl}$ & 4.672 & 4.67 & & & \\
\hline $\mathrm{NaF}$ & 0.078 & 0.08 & & & \\
\hline $\mathrm{Nal}$ & 0.079 & 0.08 & & & \\
\hline $\mathrm{NaNO}_{2}$ & 16.467 & 16.47 & & & \\
\hline $\mathrm{NaNO}_{3}$ & 5.947 & 5.95 & & & \\
\hline $\mathrm{NaOH}$ & 9.681 & 9.68 & & & \\
\hline $\mathrm{Nd}_{2} \mathrm{O}_{3}$ & 0.000 & 0.00 & & & \\
\hline $\mathrm{PbSO}_{4}$ & 0.767 & 0.77 & 0.524 & $0.20 \%$ & $0.0101 \mathrm{~Pb}$ \\
\hline $\mathrm{SiO}_{2}$ & 3.492 & 3.49 & 1.633 & $0.63 \%$ & $0.0314 \mathrm{Si}$ \\
\hline $\mathrm{SrCO}_{3}$ & 0.255 & 0.25 & 0.151 & $0.06 \%$ & $0.0029 \mathrm{Sr}$ \\
\hline Zeolite & 0.000 & 0.00 & & & \\
\hline $\mathrm{ZnO}$ & 0.692 & 0.69 & 0.556 & $0.21 \%$ & $0.0107 \mathrm{Zn}$ \\
\hline \multirow[t]{2}{*}{$\mathrm{ZrO}_{2}$} & 1.379 & 1.38 & 1.021 & $0.39 \%$ & $0.0196 \mathrm{Zr}$ \\
\hline & \multicolumn{3}{|c|}{260.77 gms. (using $\mathrm{Fe}(\mathrm{OH})_{3}$ ) } & & \\
\hline \multirow[t]{4}{*}{ Dry Solids } & \multirow{2}{*}{\multicolumn{3}{|c|}{$\begin{array}{l}260.8 \text { Includes Sludge + Supernate. } \\
\text { Sludge Solids }\end{array}$}} & & \\
\hline & & & & & \\
\hline & \multicolumn{2}{|c|}{$19.6 \%$ Total Solids } & & & \\
\hline & \multicolumn{3}{|c|}{$2.5 \%$ Soluble Solids } & & \\
\hline \multirow[t]{2}{*}{ Dry Solids } & \multirow{2}{*}{\multicolumn{3}{|c|}{$\begin{array}{l}208.0 \text { gms. (using } \mathrm{Fe}_{2} \mathrm{O}_{3} \text { ) } \\
15.6 \% \text { Total Solids }\end{array}$}} & & \\
\hline & & & & \multirow[b]{2}{*}{ Na Salts, gm } & \\
\hline Total & Anions: & Total, gms $\%$ & & & $\%$ \\
\hline $\mathrm{SO}_{4}{ }^{2-}$ & & 1.78 & $0.684 \%$ & 0.45 & $0.173 \%$ \\
\hline $\mathrm{PO}_{4}^{3-}$ & & 0.34 & $0.131 \%$ & 0.10 & $0.039 \%$ \\
\hline $\mathrm{CO}_{3}^{2-}$ & & 9.15 & $3.510 \%$ & 2.70 & $1.035 \%$ \\
\hline $\mathrm{NO}_{3}^{-}$ & & 4.54 & $1.741 \%$ & 4.34 & $1.664 \%$ \\
\hline $\mathrm{Cl}^{-}$ & & 2.83 & $1.087 \%$ & 2.83 & $1.087 \%$ \\
\hline$F^{-}$ & & 0.04 & $0.013 \%$ & 0.04 & $0.013 \%$ \\
\hline$r^{-}$ & & 0.07 & $0.026 \%$ & 0.07 & $0.026 \%$ \\
\hline $\mathrm{NO}_{2}^{-}$ & & 10.98 & $4.211 \%$ & 10.98 & $4.211 \%$ \\
\hline $\mathrm{OH}^{-}$(tot) & & 83.05 & $31.849 \%$ & 4.12 & $1.579 \%$ \\
\hline $\mathrm{O}^{2-}$ & & 12.92 & $4.954 \%$ & 2.83 & \\
\hline SUM= & & $\overline{125.71} \mathrm{~g}$ & $\mathrm{~ms}$ & 45.37 & $16.310 \%$ \\
\hline
\end{tabular}


WSRC-TR-2004-00206

Revision 0

Table B- 5. Recipe Calculation for 15 wt \% Uranium Sludge Batch 2 Simulant

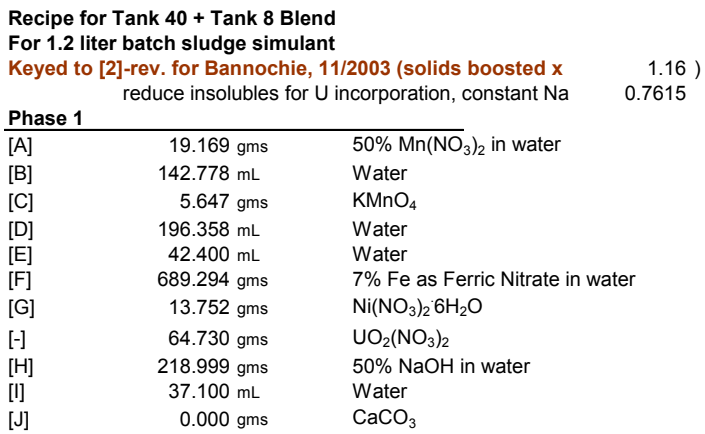

This converts to these solids (iron phase must be guessed)

\begin{tabular}{lrrrrr} 
& gms & \multicolumn{5}{c}{ My check: } & elements: & Total in sludge solids \\
$\mathrm{MnO}_{2}$ & 7.762 & 7.76 & 4.91 & $1.88 \%$ & $0.1017 \mathrm{Mn}$ \\
$\mathrm{Fe}_{2} \mathrm{O}_{3}$ & 79.587 & 33.75 & & & \\
$\mathrm{Fe}(\mathrm{OH})_{3}$ & 92.333 & 92.33 & 48.25 & $18.50 \%$ & $1.0000 \mathrm{Fe}$ \\
$\mathrm{Ni}(\mathrm{OH})_{2}$ & 4.380 & 4.38 & 2.78 & $1.06 \%$ & $0.0575 \mathrm{Ni}$ \\
$\mathrm{Na}_{2} \mathrm{U}_{2} \mathrm{O}_{7}$ & 52.084 & 52.08 & 39.10 & $15.00 \%$ & $0.8105 \mathrm{U}$ \\
$\mathrm{CaCO}_{3}$ & 0.00 & 0.00 & - & see below \\
\multicolumn{7}{|l}{} \\
\multicolumn{7}{|l}{ The soluble portion must be removed by thorough washing. }
\end{tabular}

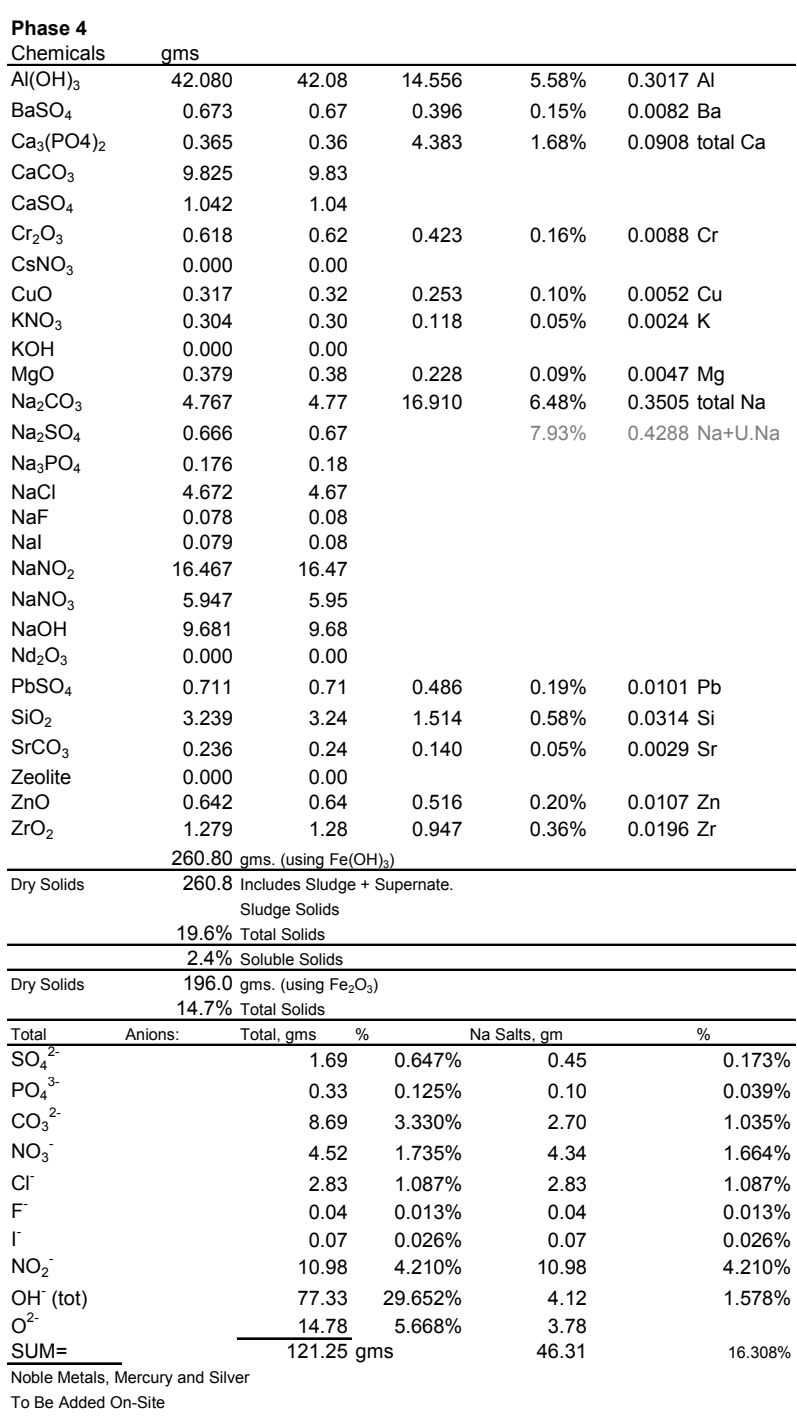


WSRC-TR-2004-00206

Revision 0

\section{APPENDIX C. PARTICLE SIZE MEASUREMENTS}


WSRC-TR-2004-00206

Revision 0

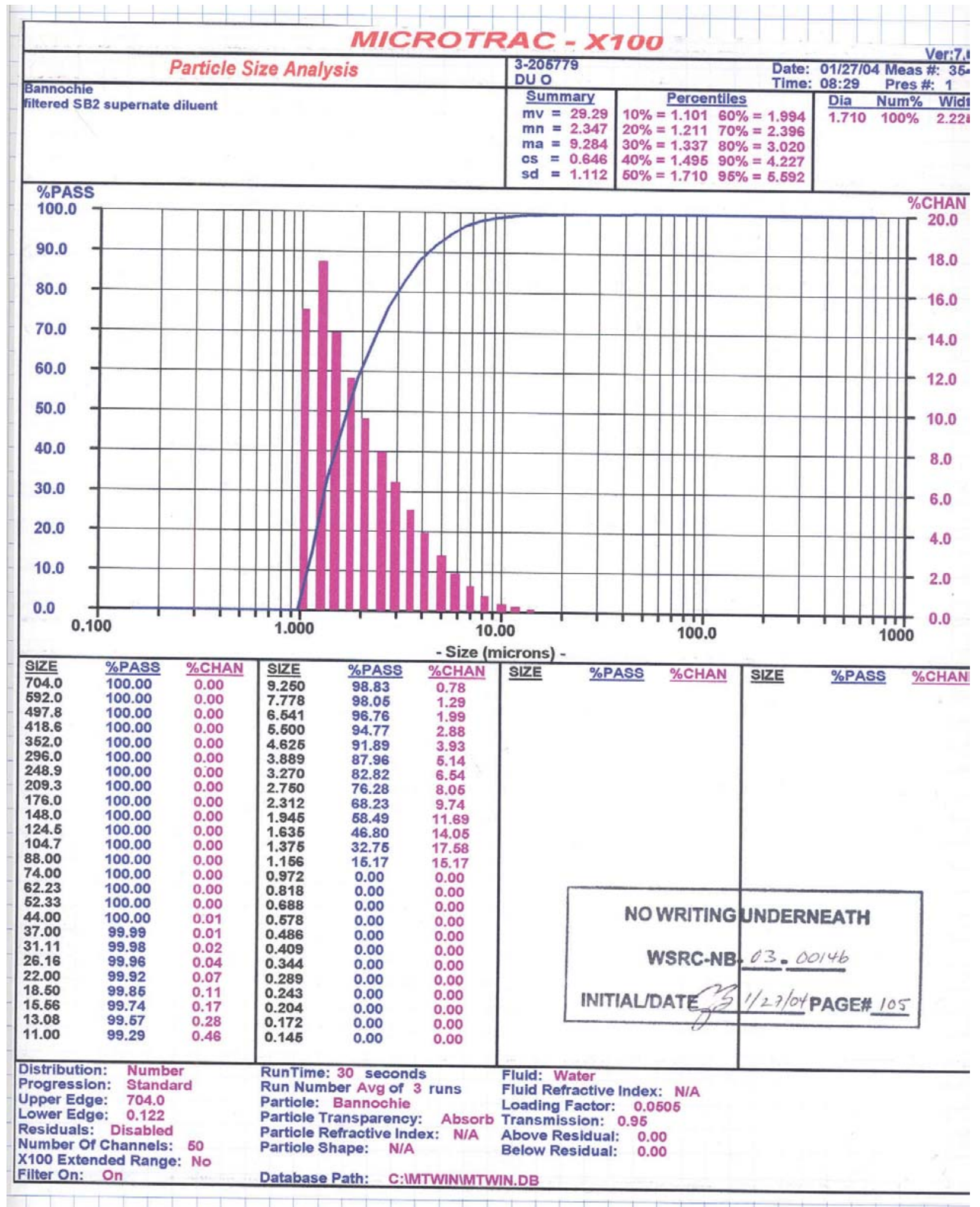

Figure C- 1. Particle size number distribution for SB2 simulant without uranium 
WSRC-TR-2004-00206

Revision 0

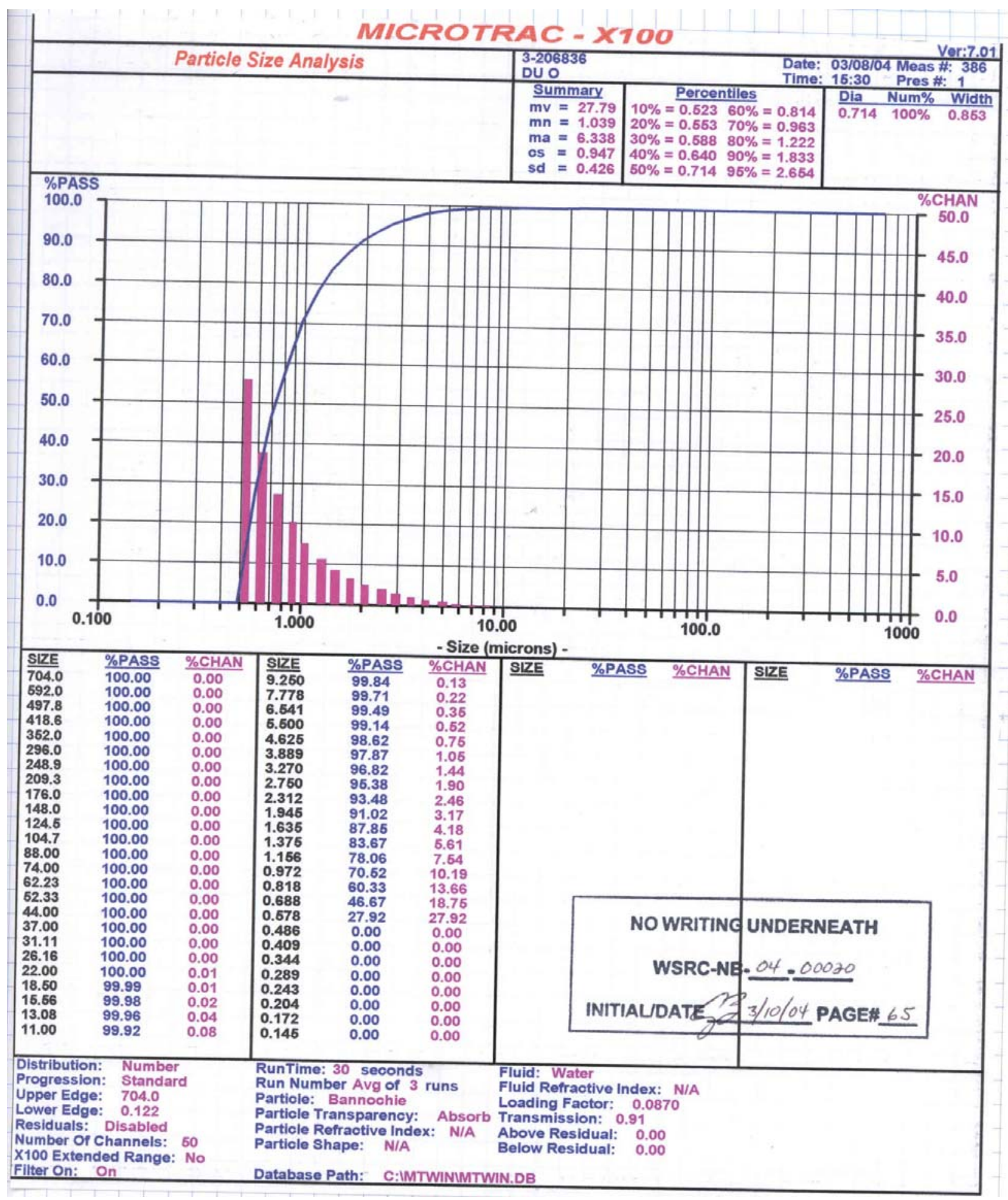

Figure C- 2. Particle size number distribution for SB2 simulant without uranium following SRAT cycle processing 
WSRC-TR-2004-00206

Revision 0

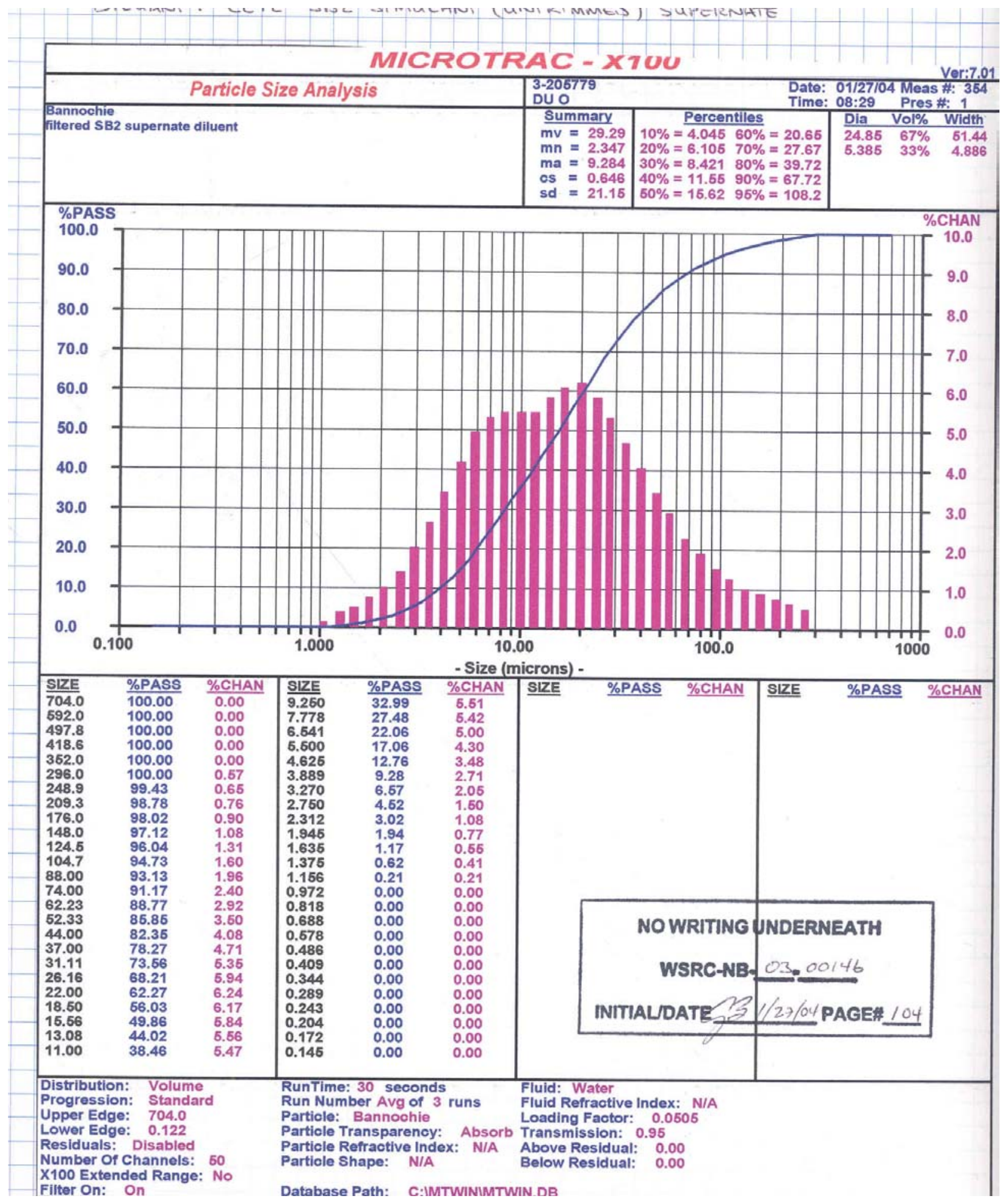

Figure C- 3. Particle size volume distribution for SB2 simulant without uranium 
WSRC-TR-2004-00206

Revision 0

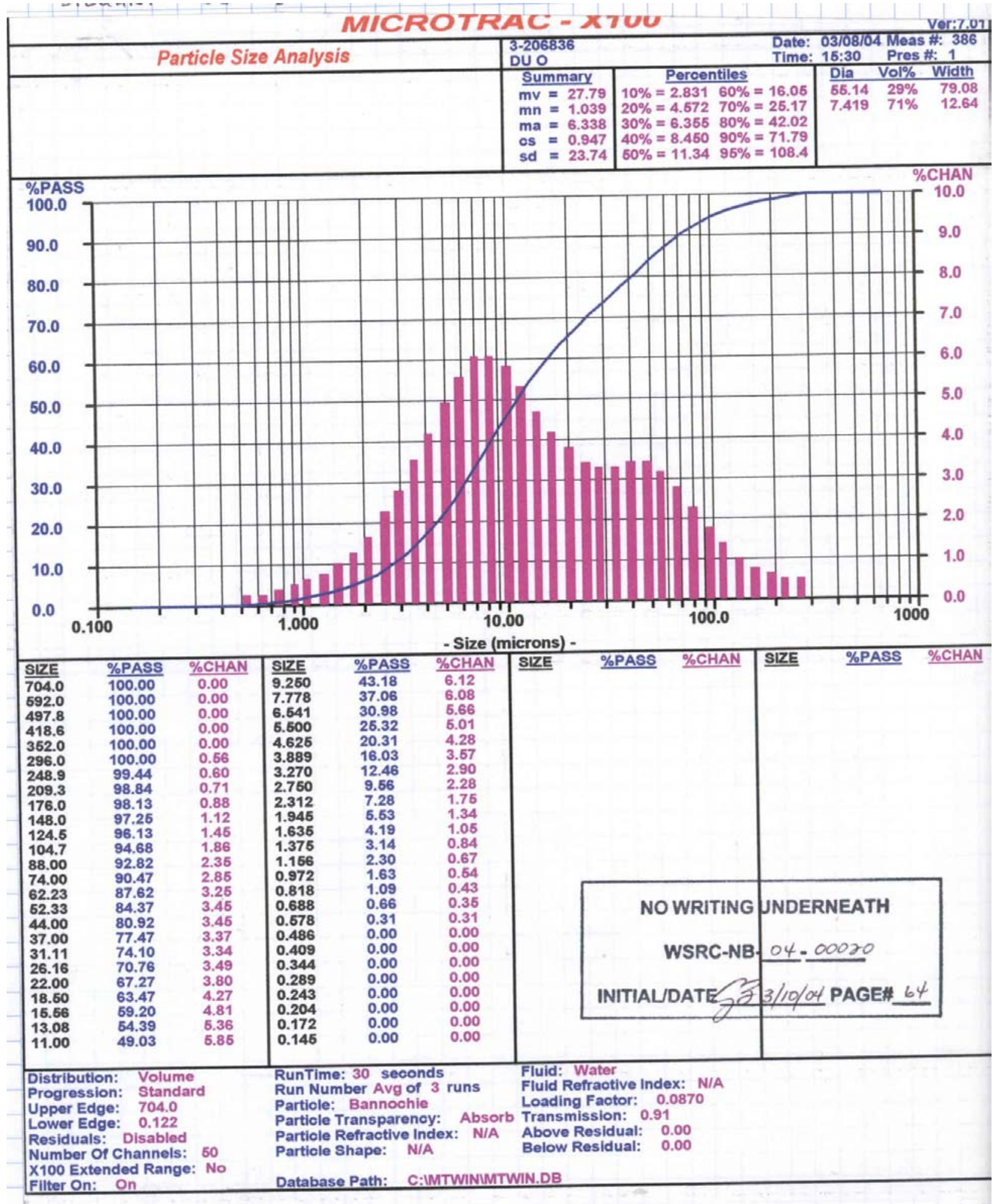

Figure C- 4. Particle size volume distribution for SB2 simulant without uranium following SRAT cycle processing 
WSRC-TR-2004-00206

Revision 0

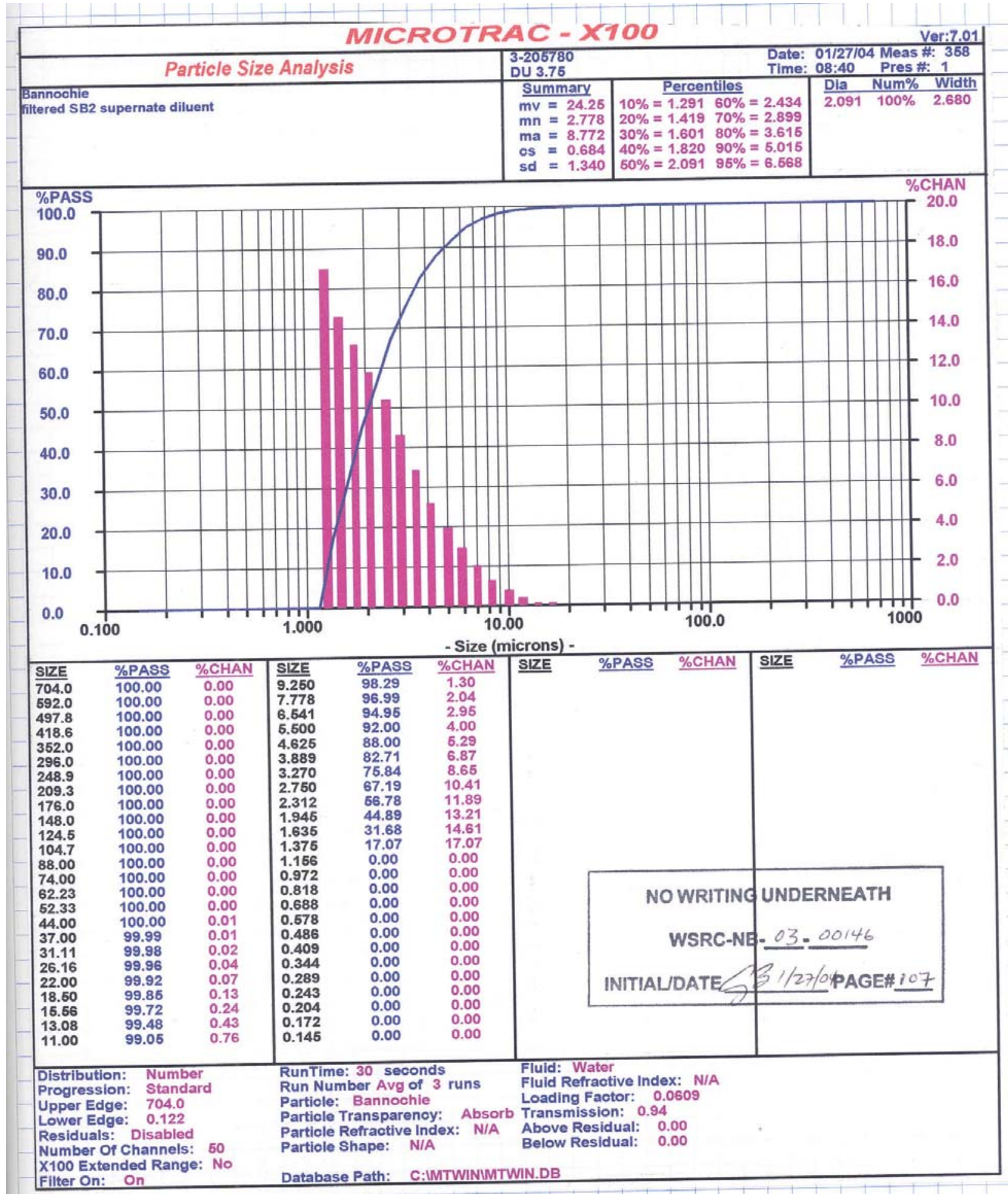

Figure C- 5. Particle size number distribution for SB2 simulant with $3.75 \mathrm{wt} \%$ uranium 
WSRC-TR-2004-00206

Revision 0

MICROTRRAC - XTUU

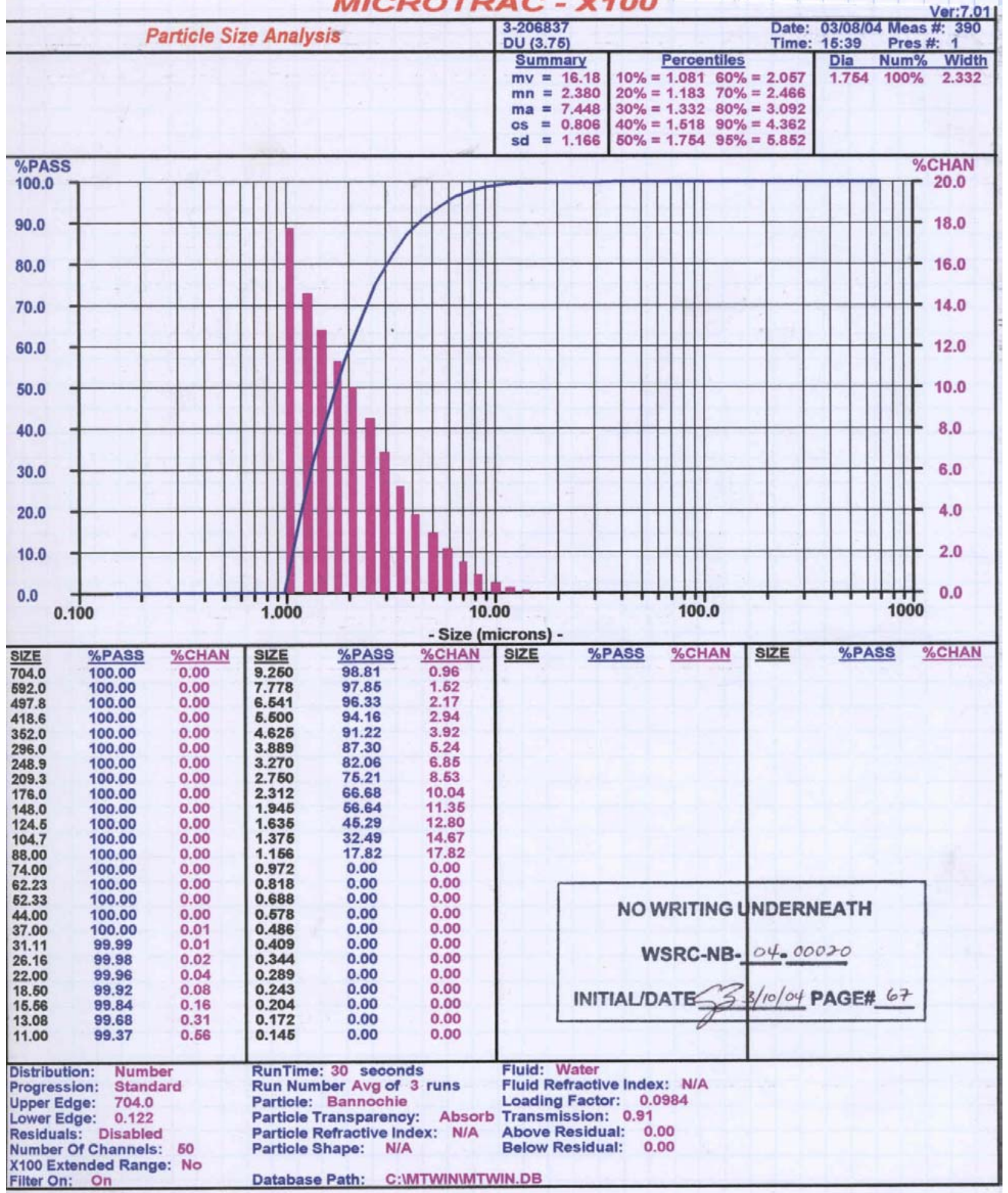

Figure C- 6. Particle size number distribution for SB2 simulant with $3.75 \mathrm{wt} \%$ uranium following SRAT cycle processing 
WSRC-TR-2004-00206

Revision 0

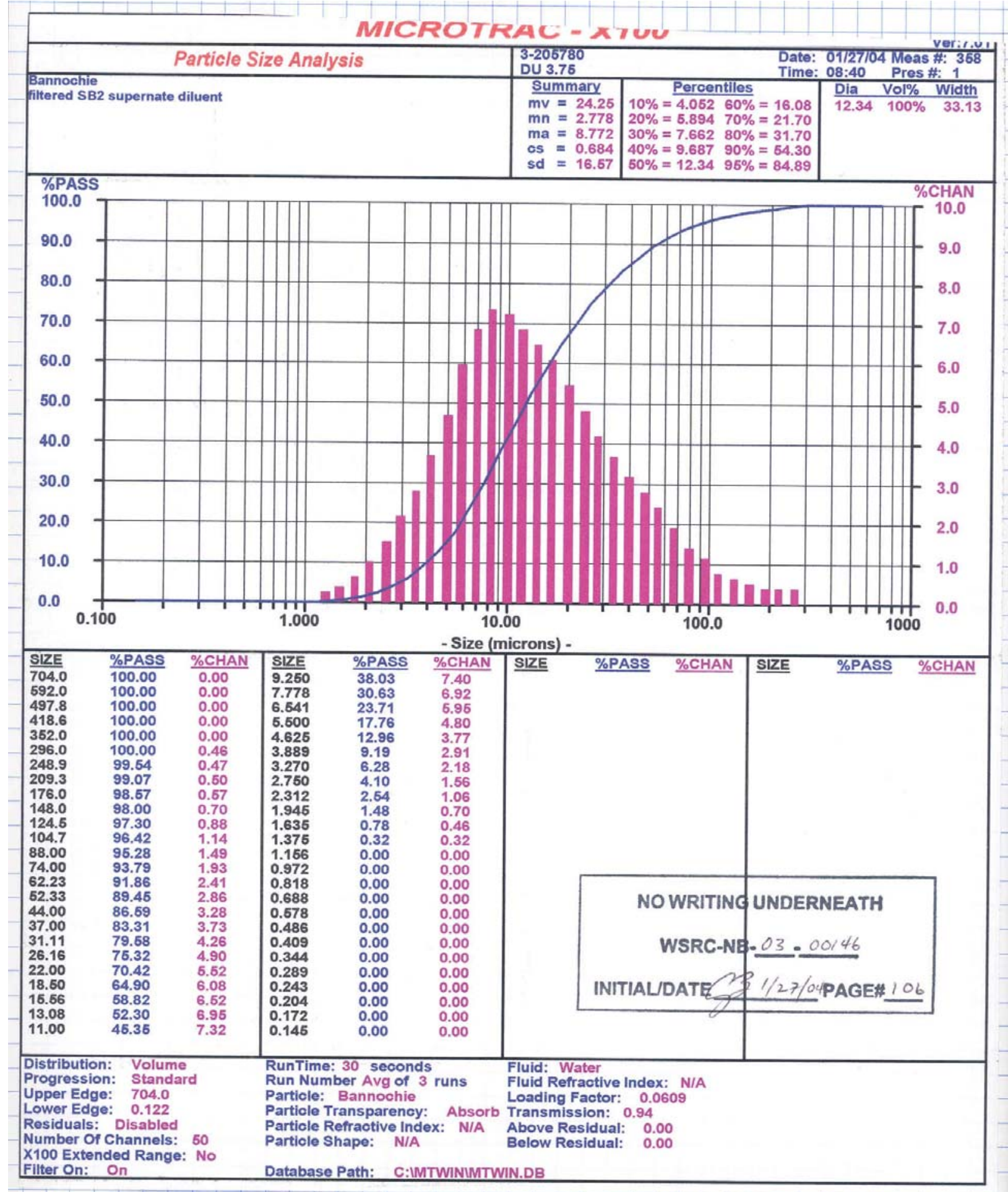

Figure C- 7. Particle size volume distribution for SB2 simulant with 3.75 wt \% uranium 
WSRC-TR-2004-00206

Revision 0

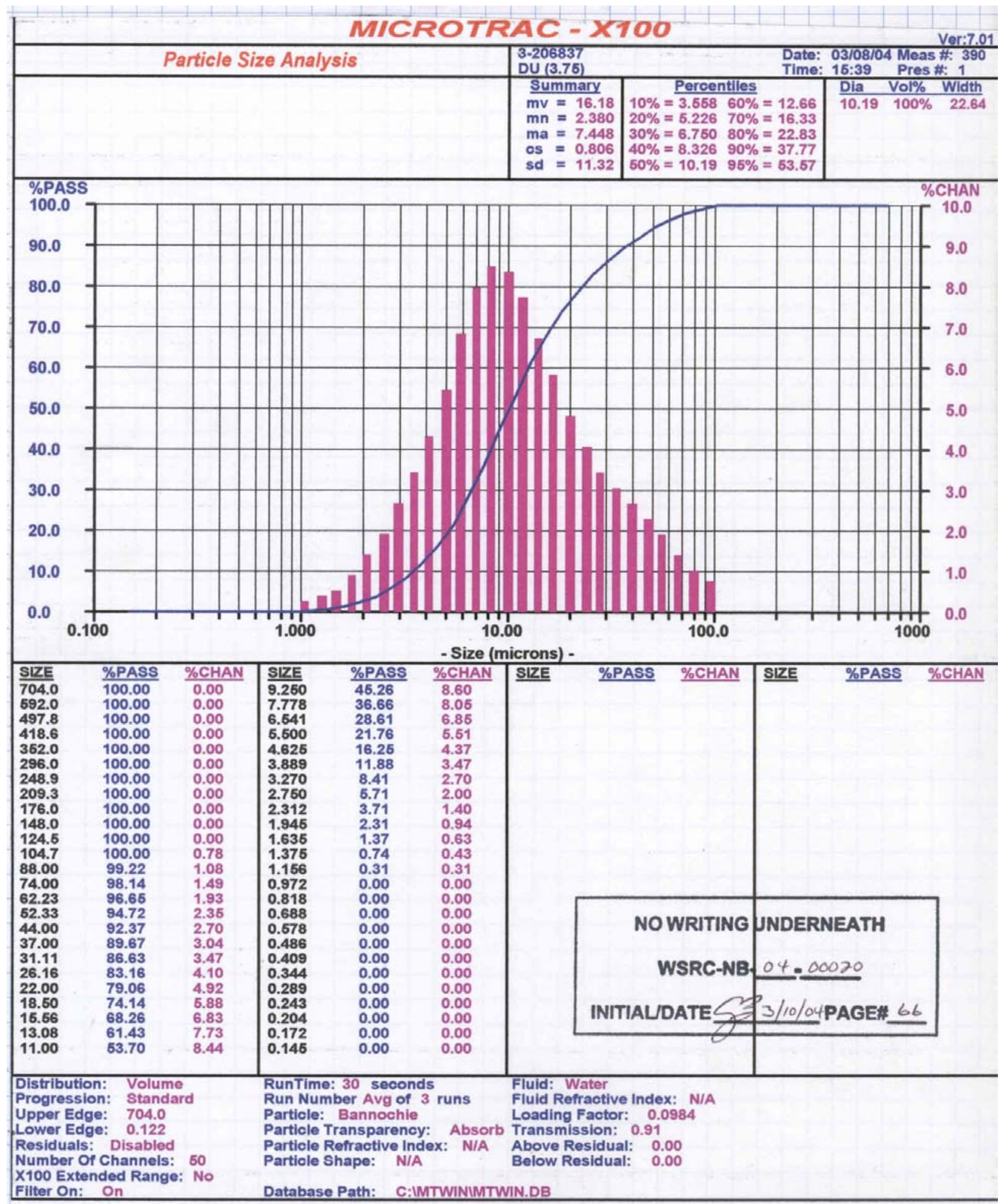

Figure C- 8. Particle size volume distribution for SB2 simulant with 3.75 wt \% uranium following SRAT cycle processing 
WSRC-TR-2004-00206

Revision 0

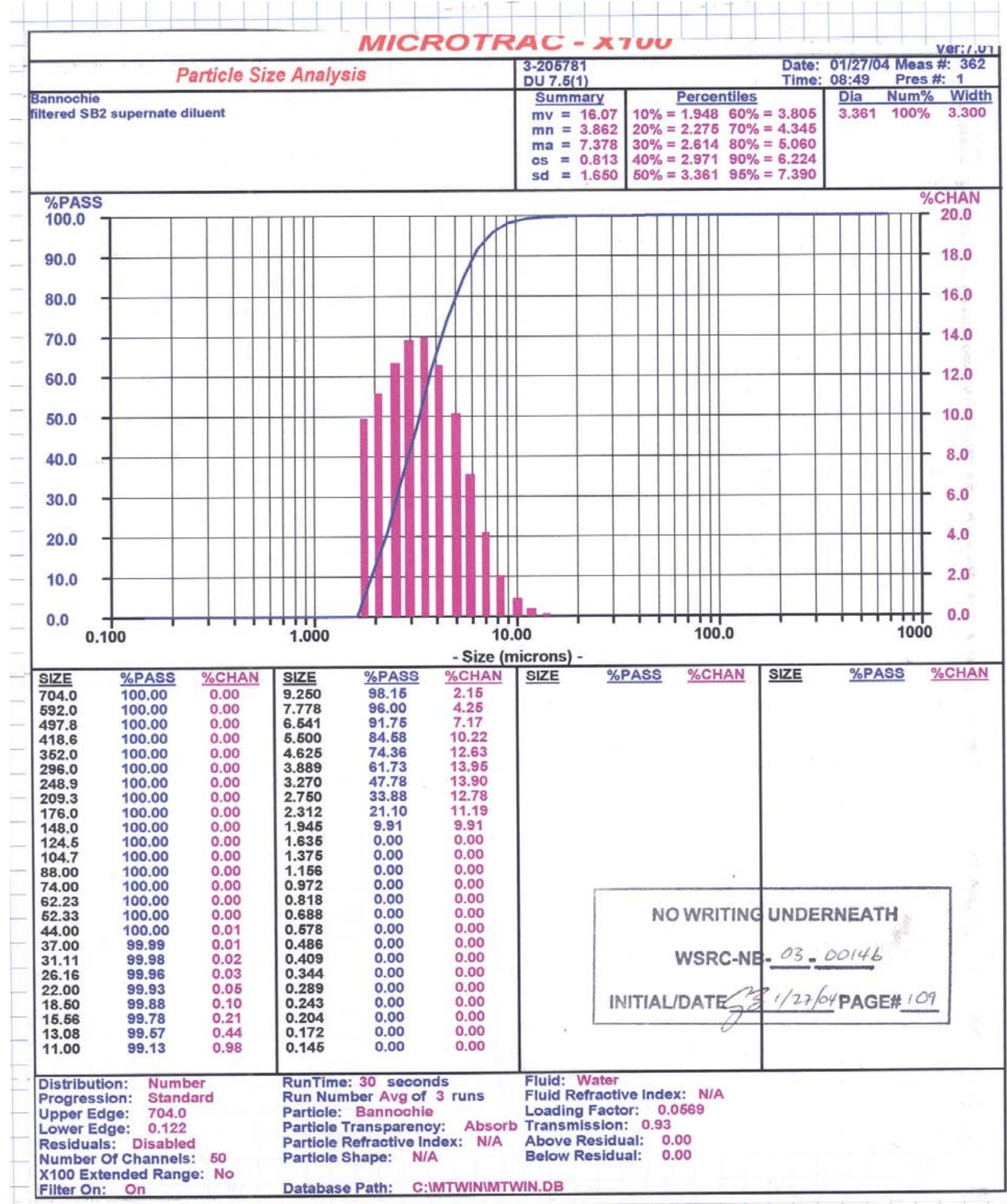

Figure C- 9. Particle size number distribution for SB2 simulant with $7.5 i$ wt $\%$ uranium 
WSRC-TR-2004-00206

Revision 0

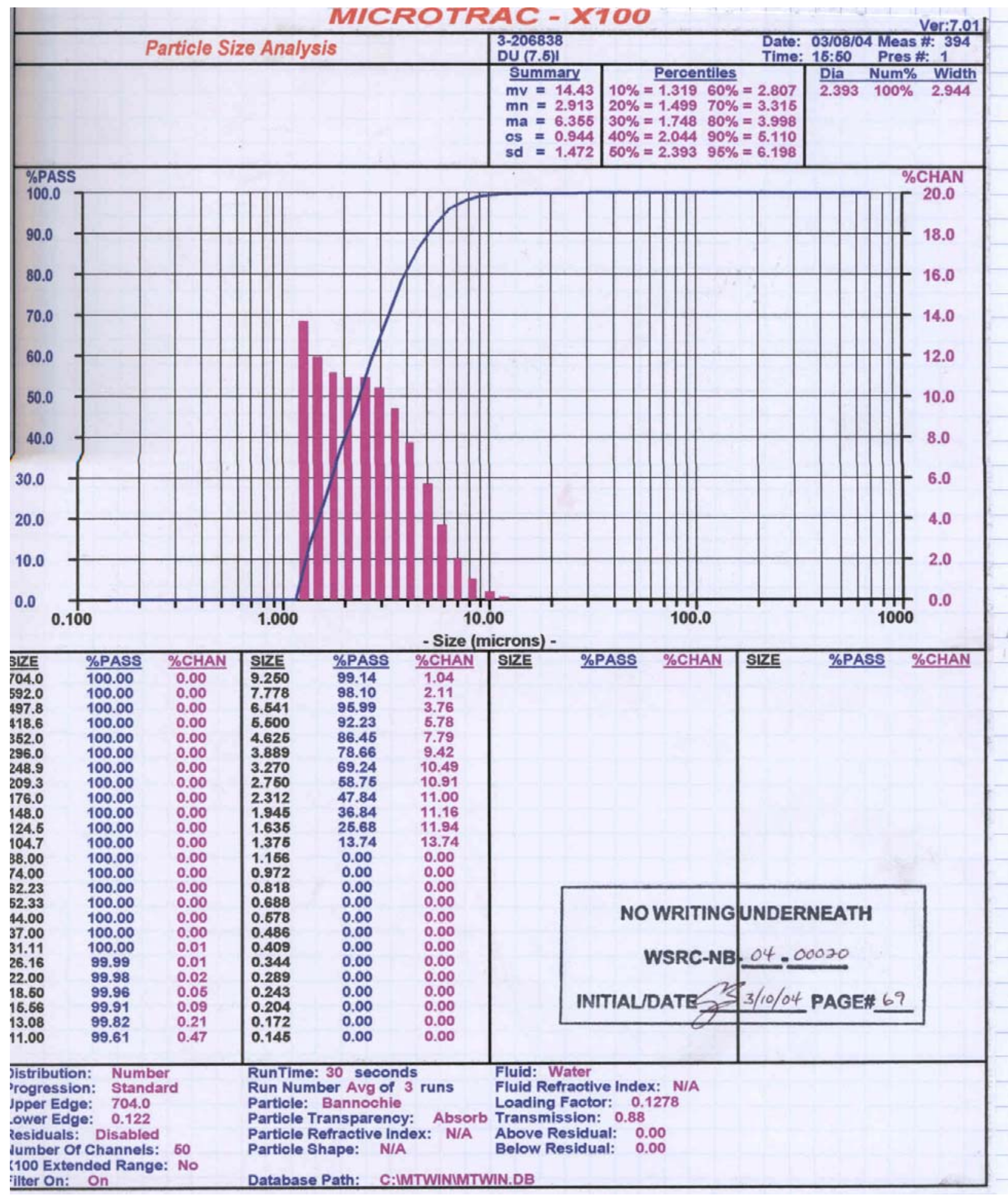

Figure C- 10. Particle size number distribution for SB2 simulant with 7.5i wt \% uranium following SRAT cycle processing 
WSRC-TR-2004-00206

Revision 0

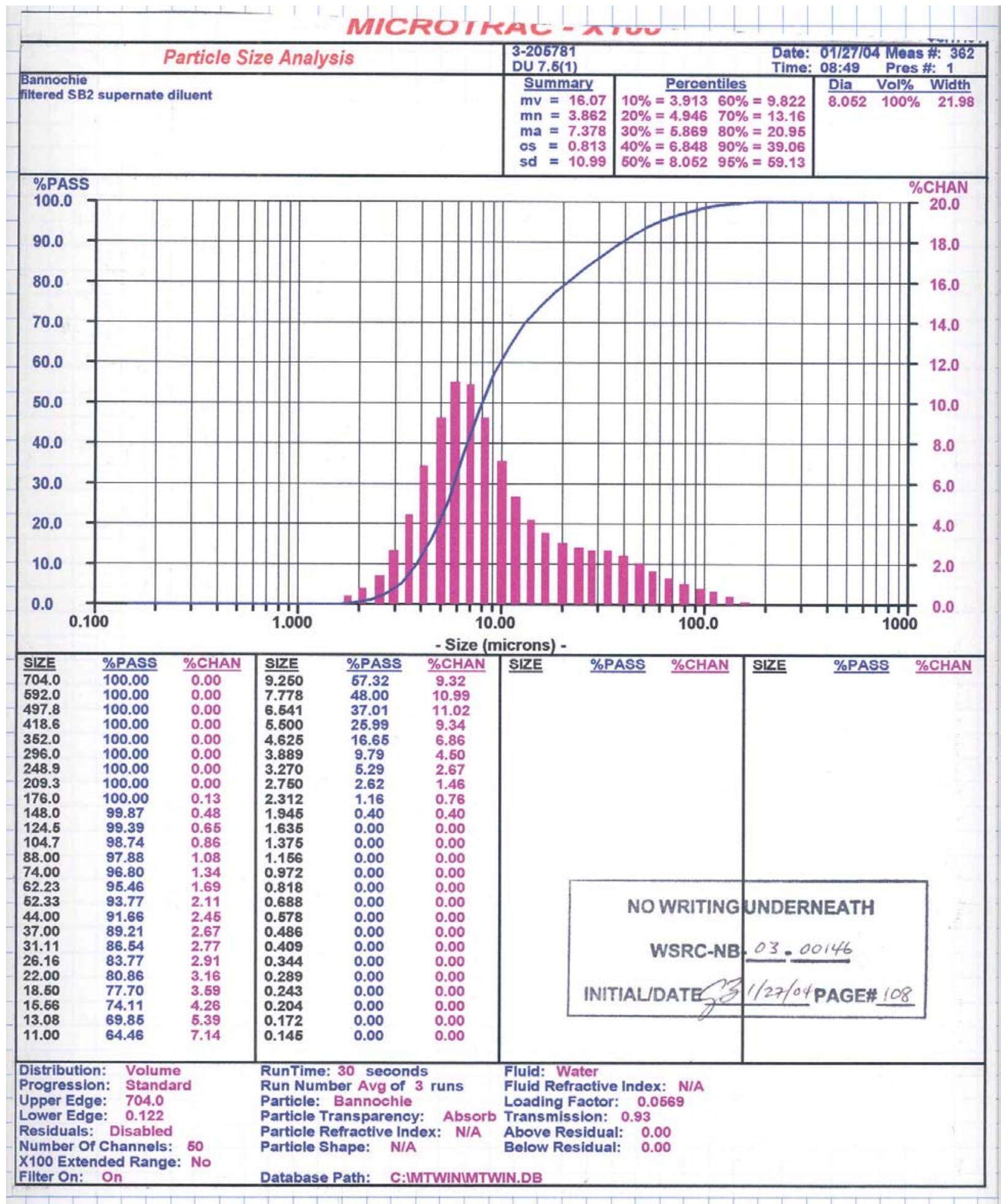

Figure C- 11. Particle size volume distribution for SB2 simulant with $7.5 \mathrm{i}$ wt \% uranium 
WSRC-TR-2004-00206

Revision 0

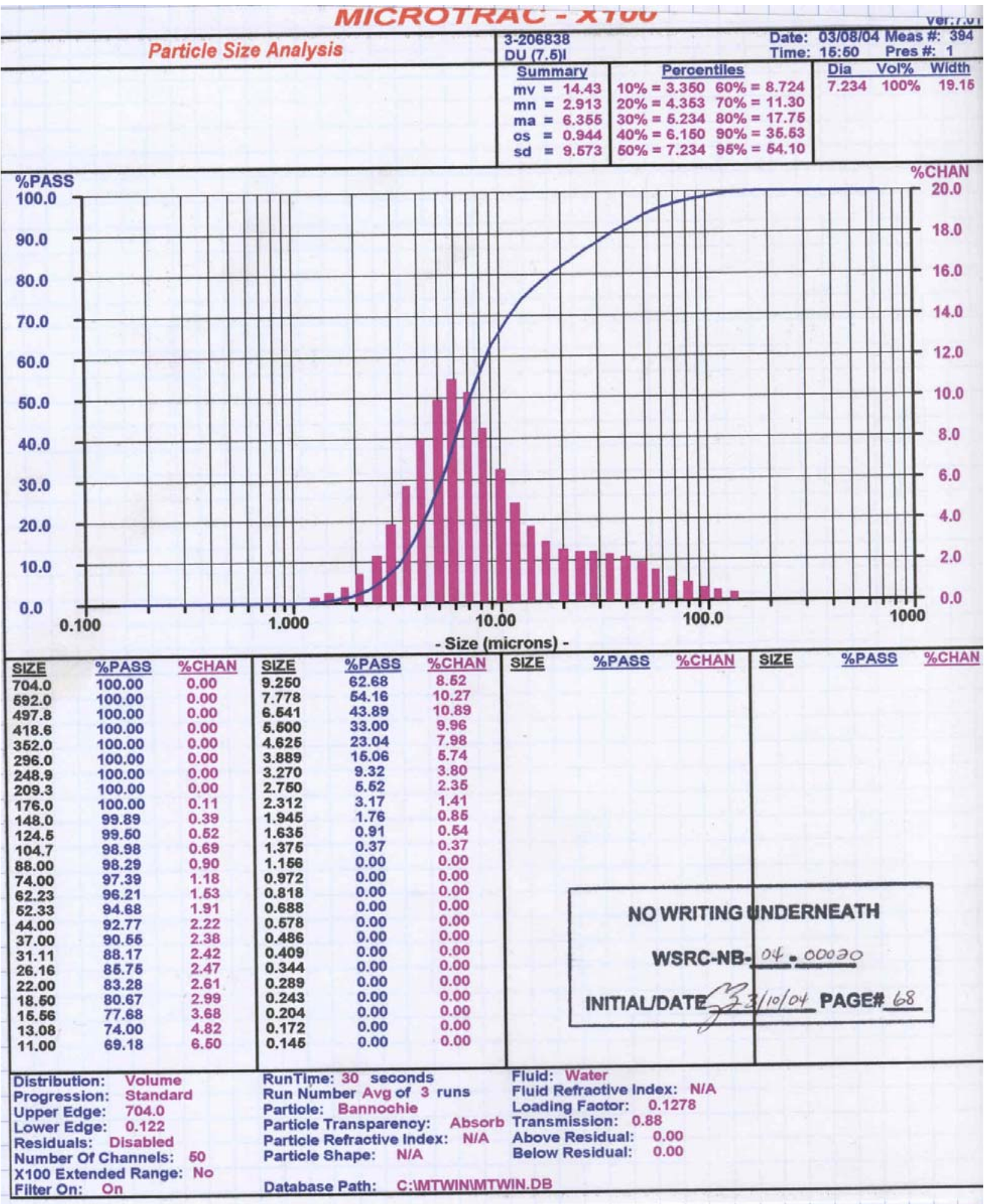

Figure C- 12. Particle size volume distribution for SB2 simulant with $7.5 \mathrm{i}$ wt \% uranium following SRAT cycle processing 
WSRC-TR-2004-00206

Revision 0

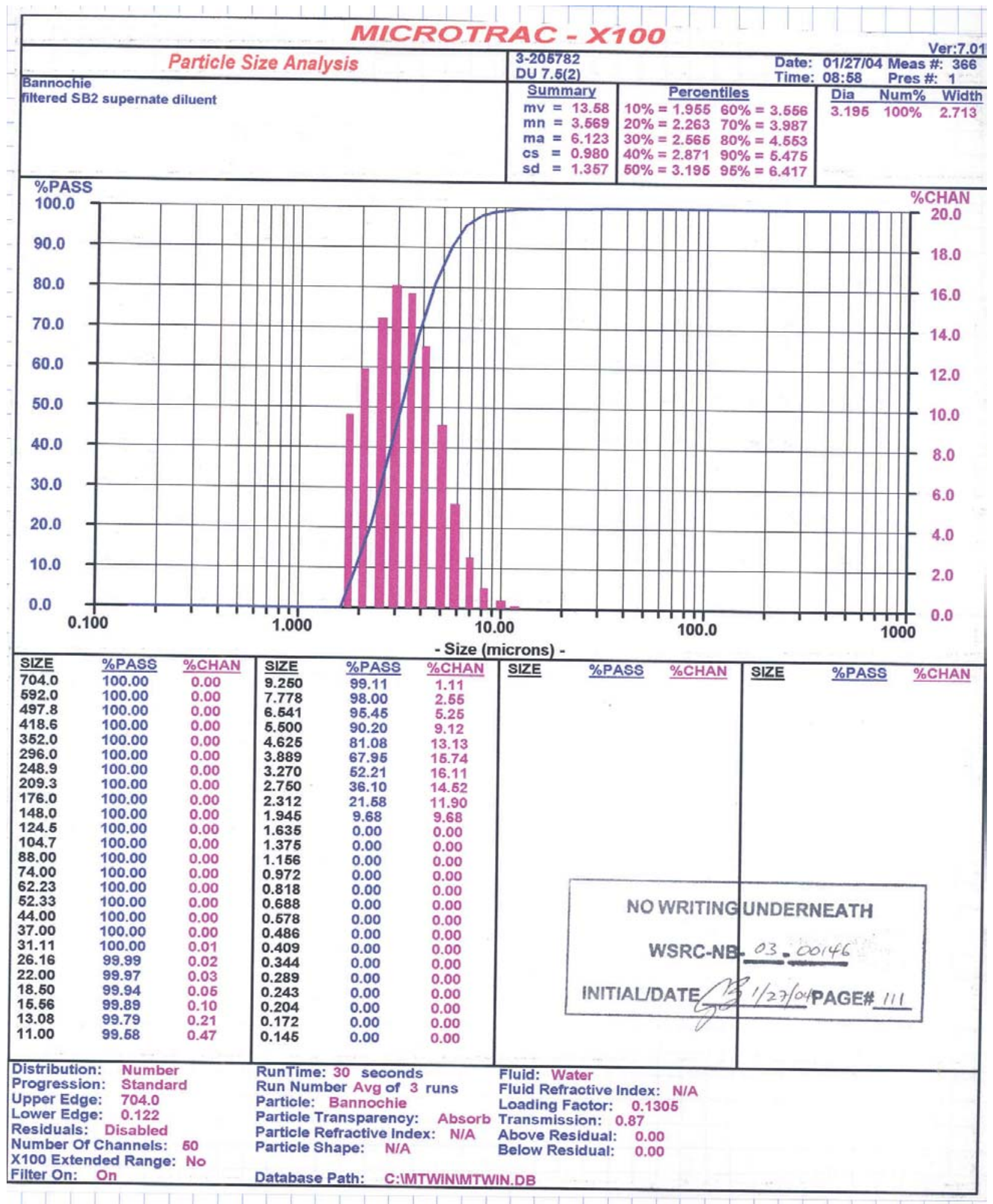

Figure C- 13. Particle size number distribution for SB2 simulant with 7.5 ii wt $\%$ uranium 
WSRC-TR-2004-00206

Revision 0

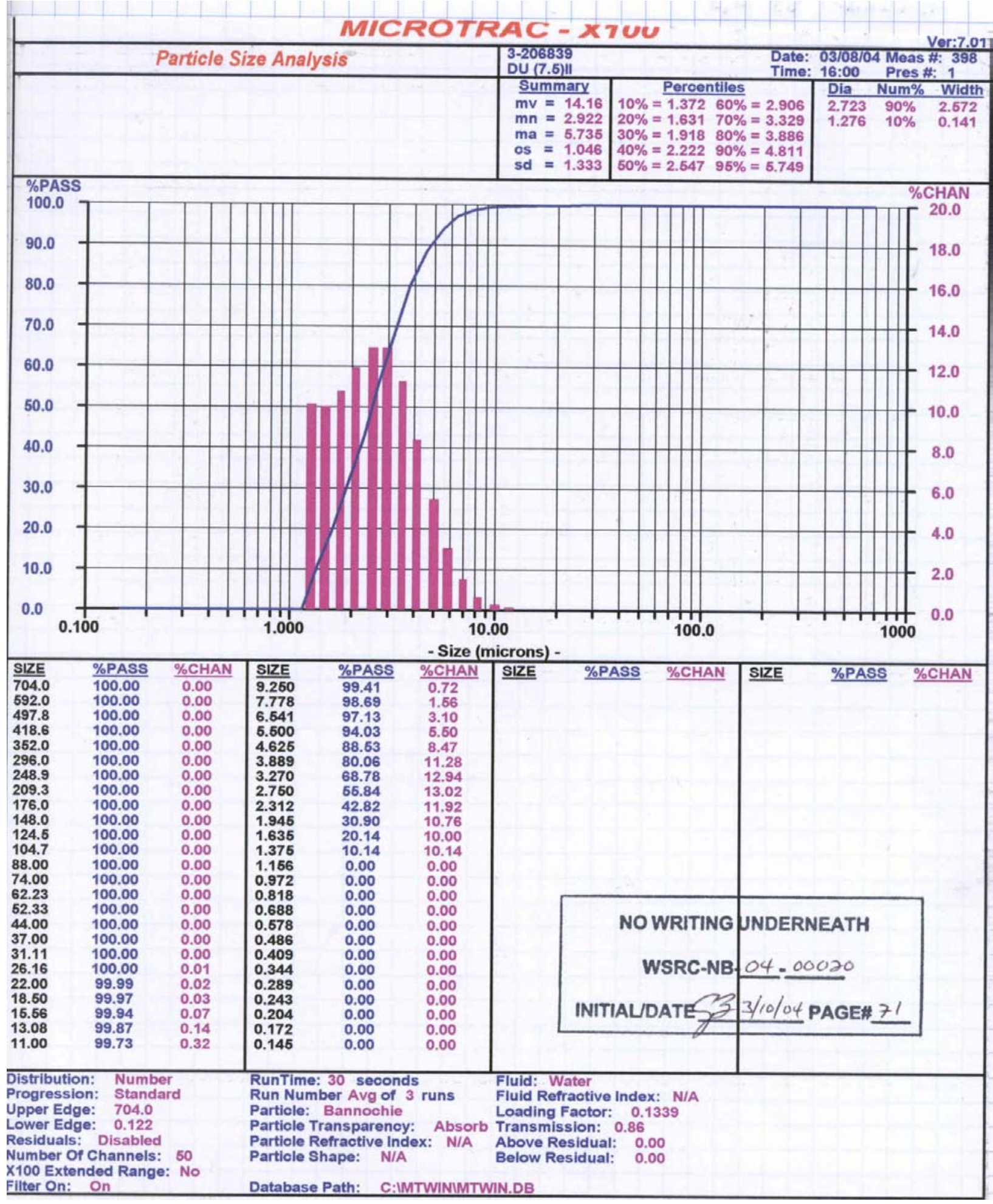

Figure C- 14. Particle size number distribution for SB2 simulant with 7.5ii wt \% uranium following SRAT cycle processing 
WSRC-TR-2004-00206

Revision 0

DILUANT: CEETL SB2 SIMULANT (UINTRIMMED) SUPERNATE

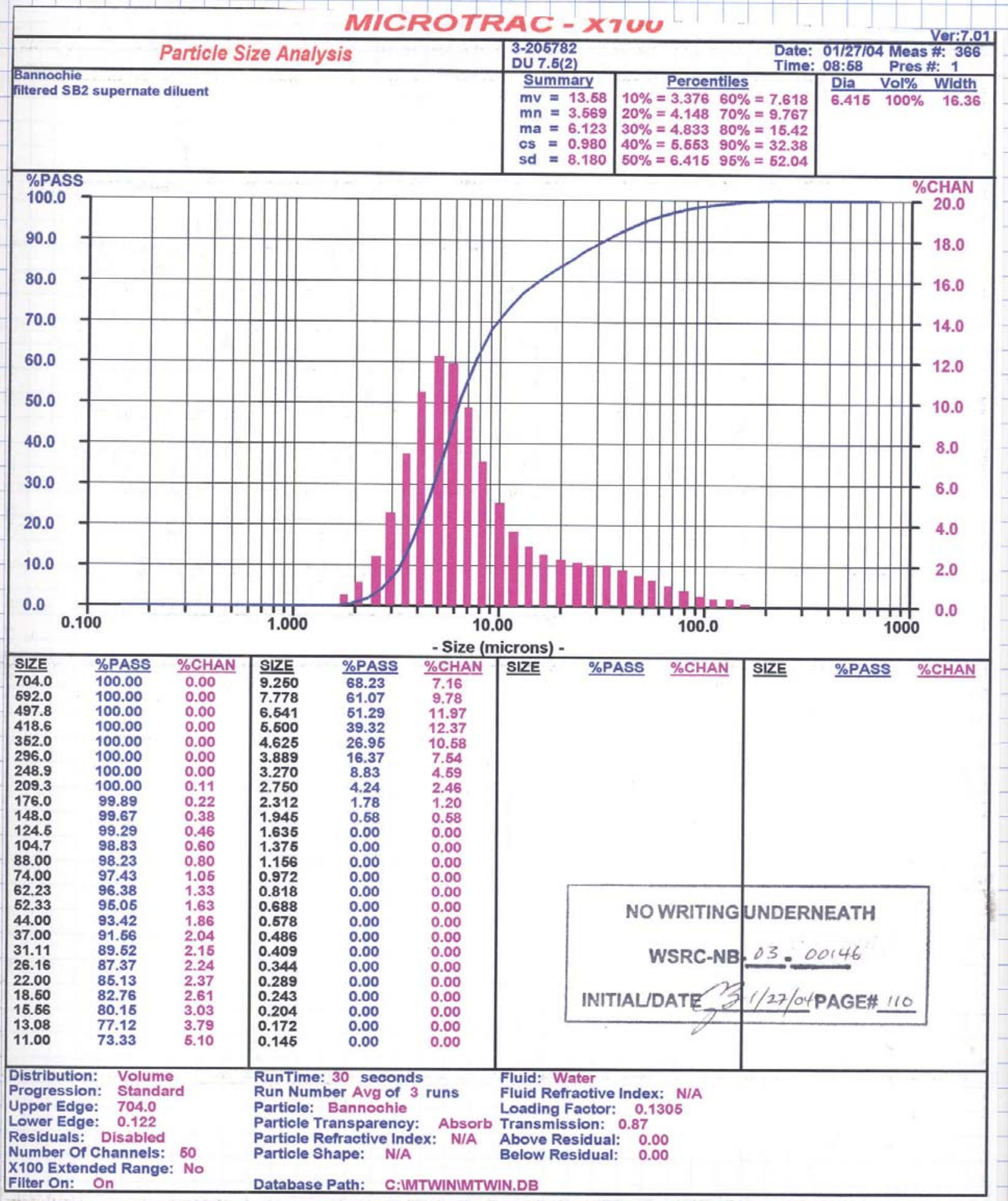

Figure C- 15. Particle size volume distribution for SB2 simulant with 7.5ii wt \% uranium 
WSRC-TR-2004-00206

Revision 0

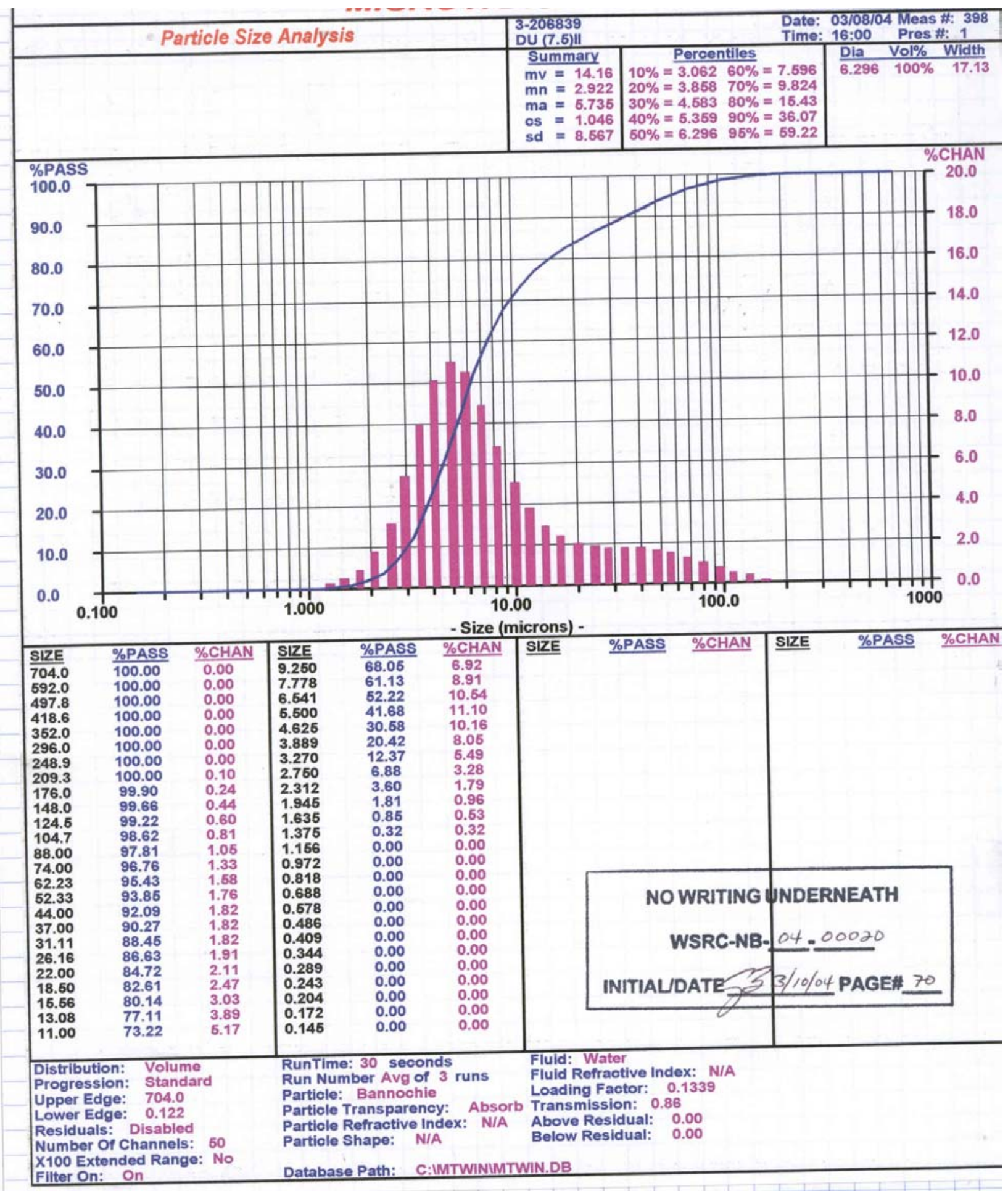

Figure C- 16. Particle size volume distribution for SB2 simulant with 7.5ii wt \% uranium following SRAT cycle processing 
WSRC-TR-2004-00206

Revision 0

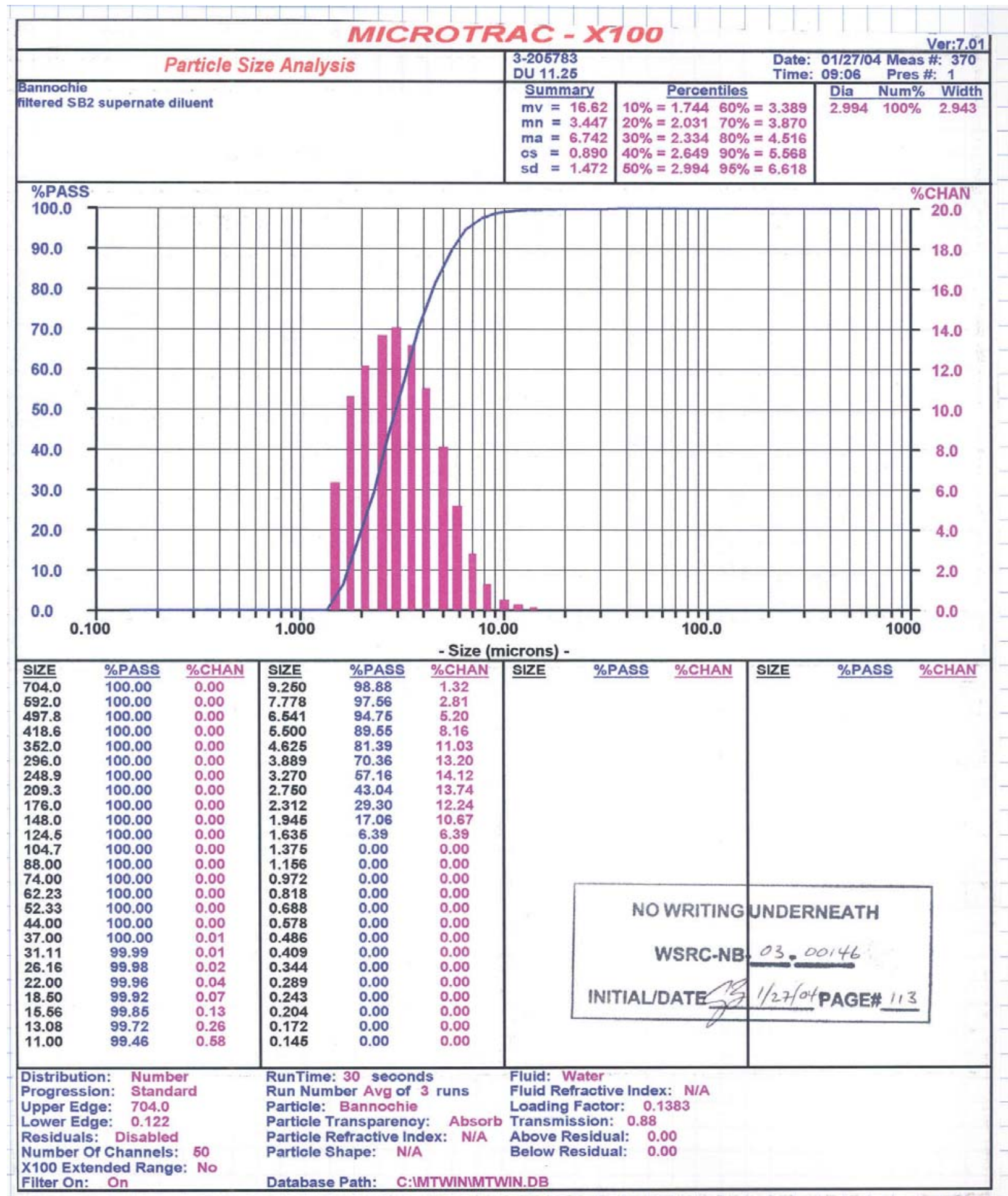

Figure C- 17. Particle size number distribution for SB2 simulant with 11.25 wt \% uranium 
WSRC-TR-2004-00206

Revision 0

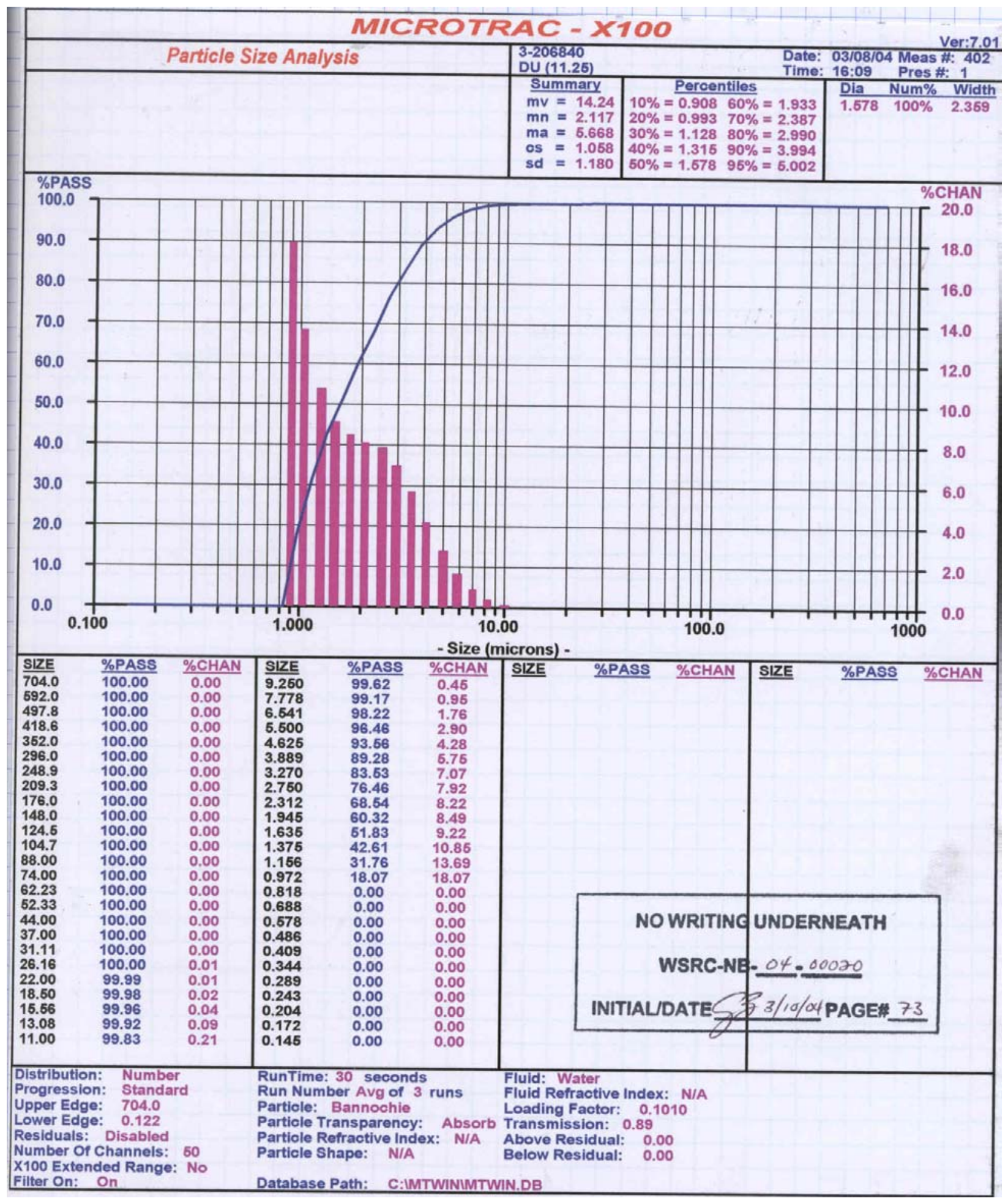

Figure C- 18. Particle size number distribution for SB2 simulant with $11.25 \mathrm{wt} \%$ uranium following SRAT cycle processing 
WSRC-TR-2004-00206

Revision 0

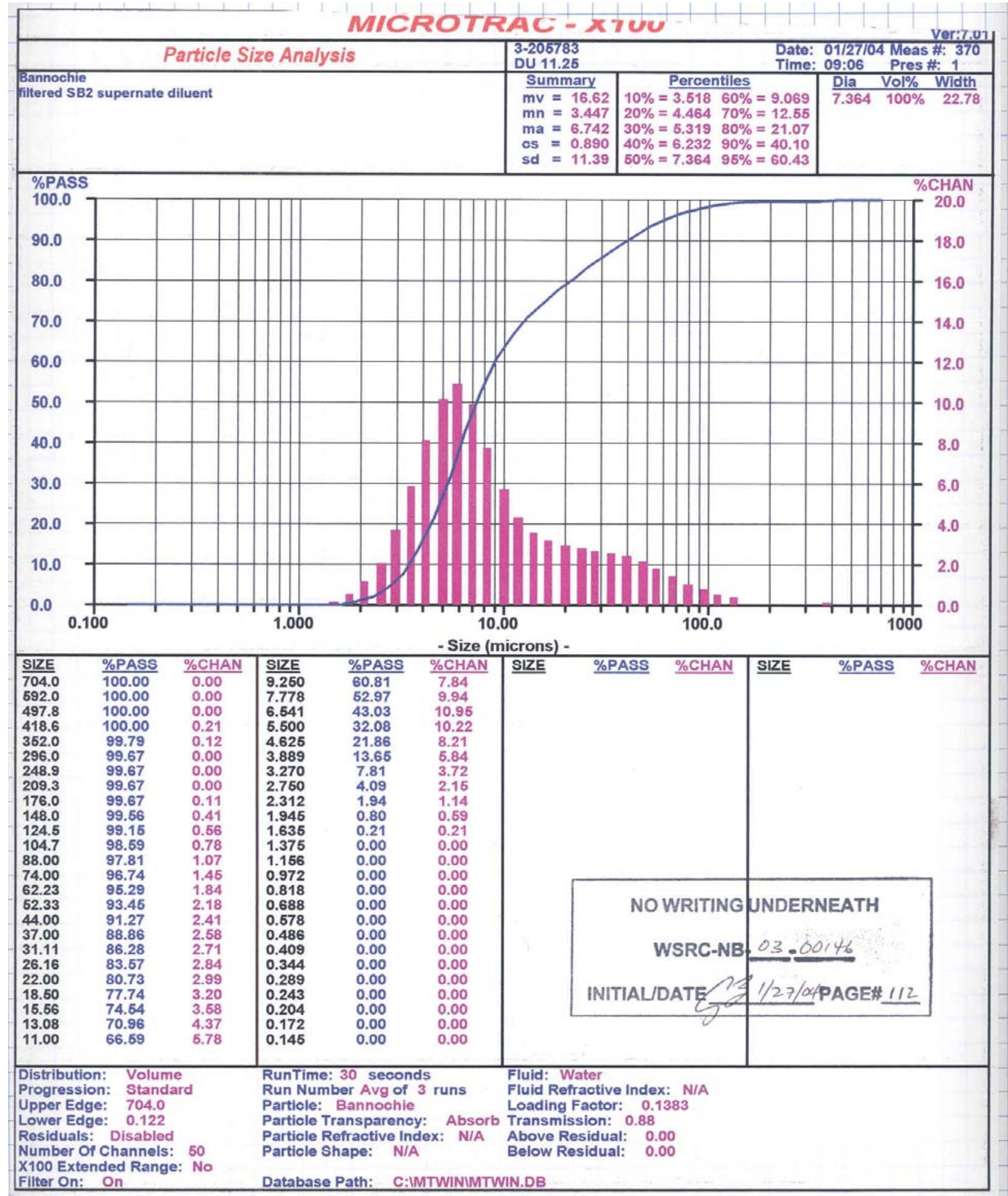

Figure C- 19. Particle size volume distribution for SB2 simulant with 11.25 wt \% uranium 
WSRC-TR-2004-00206

Revision 0

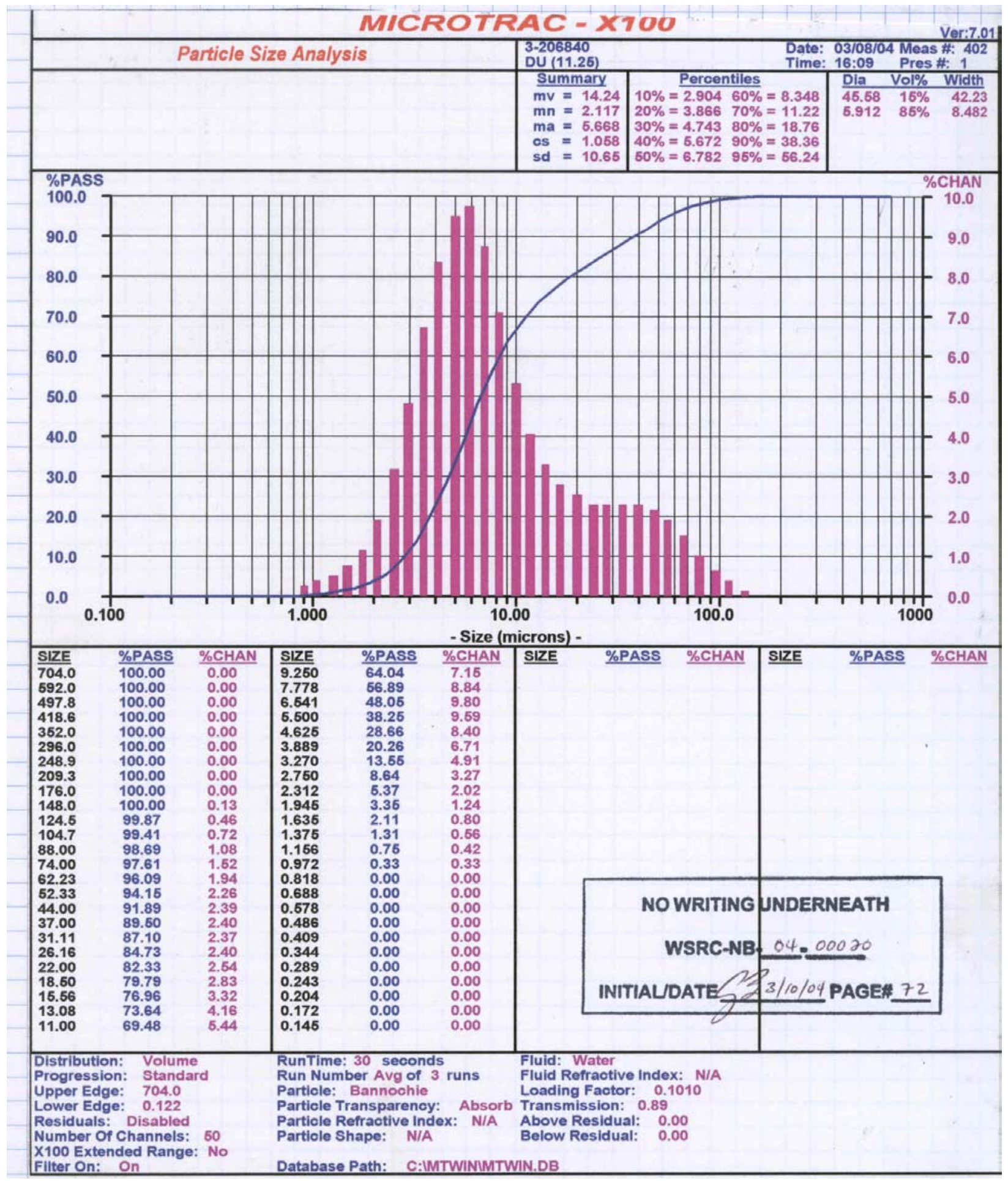

Figure C- 20. Particle size volume distribution for SB2 simulant with $11.25 \mathrm{wt} \%$ uranium following SRAT cycle processing 
WSRC-TR-2004-00206

Revision 0

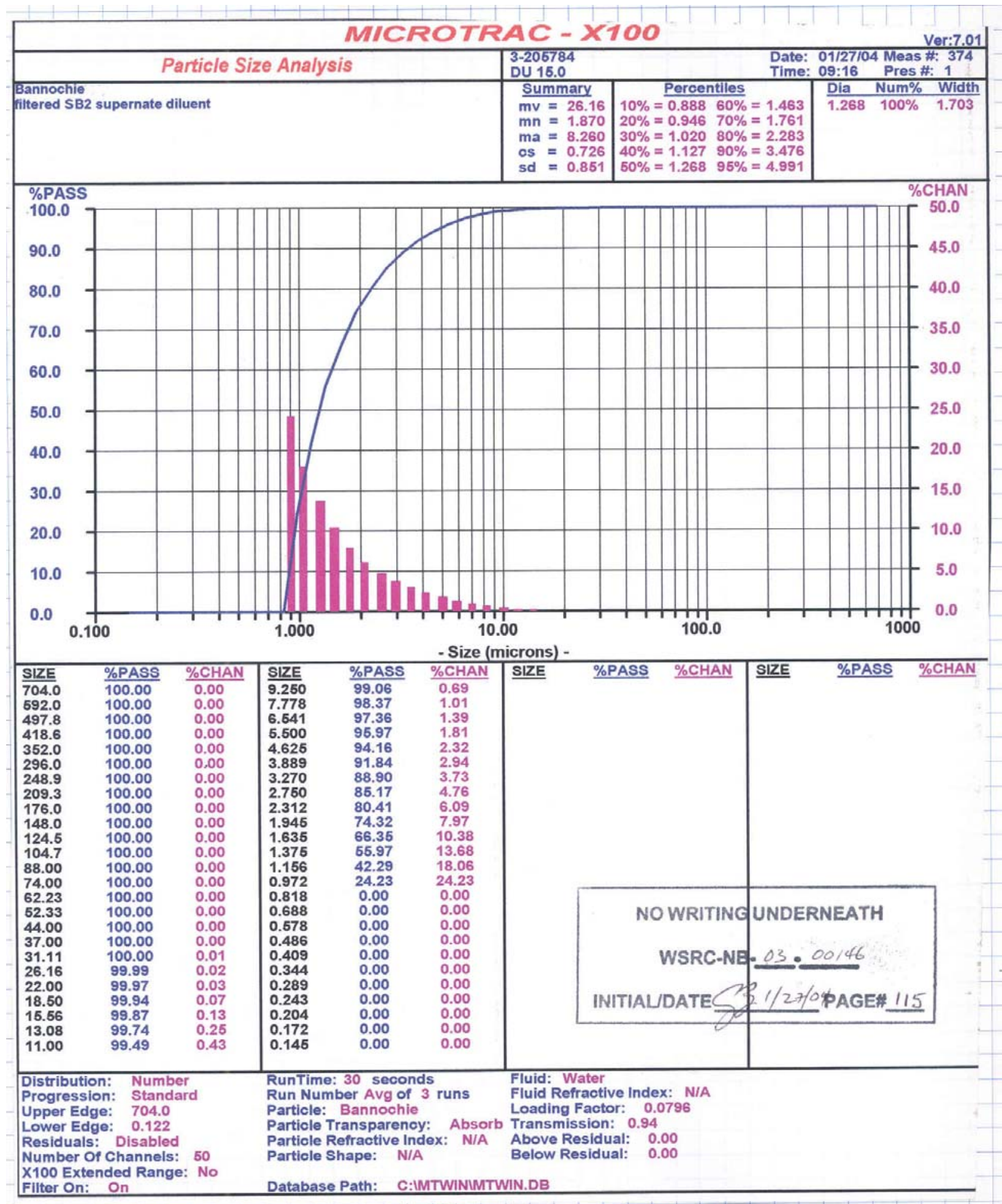

Figure C- 21. Particle size number distribution for SB2 simulant with $15 \mathrm{wt} \%$ uranium 
WSRC-TR-2004-00206

Revision 0

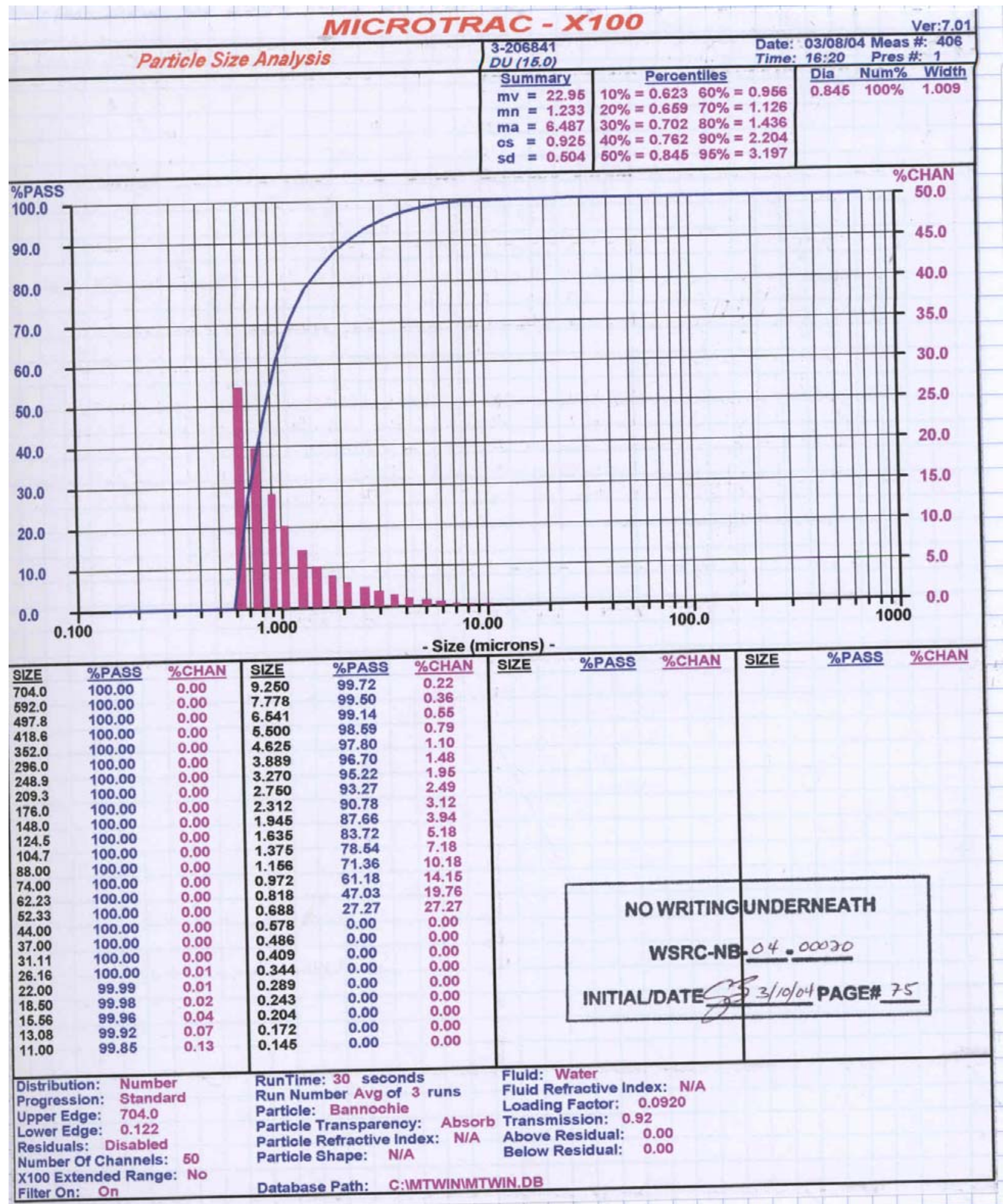

Figure C- 22. Particle size number distribution for SB2 simulant with $15 \mathrm{wt} \%$ uranium following SRAT cycle processing 
WSRC-TR-2004-00206

Revision 0

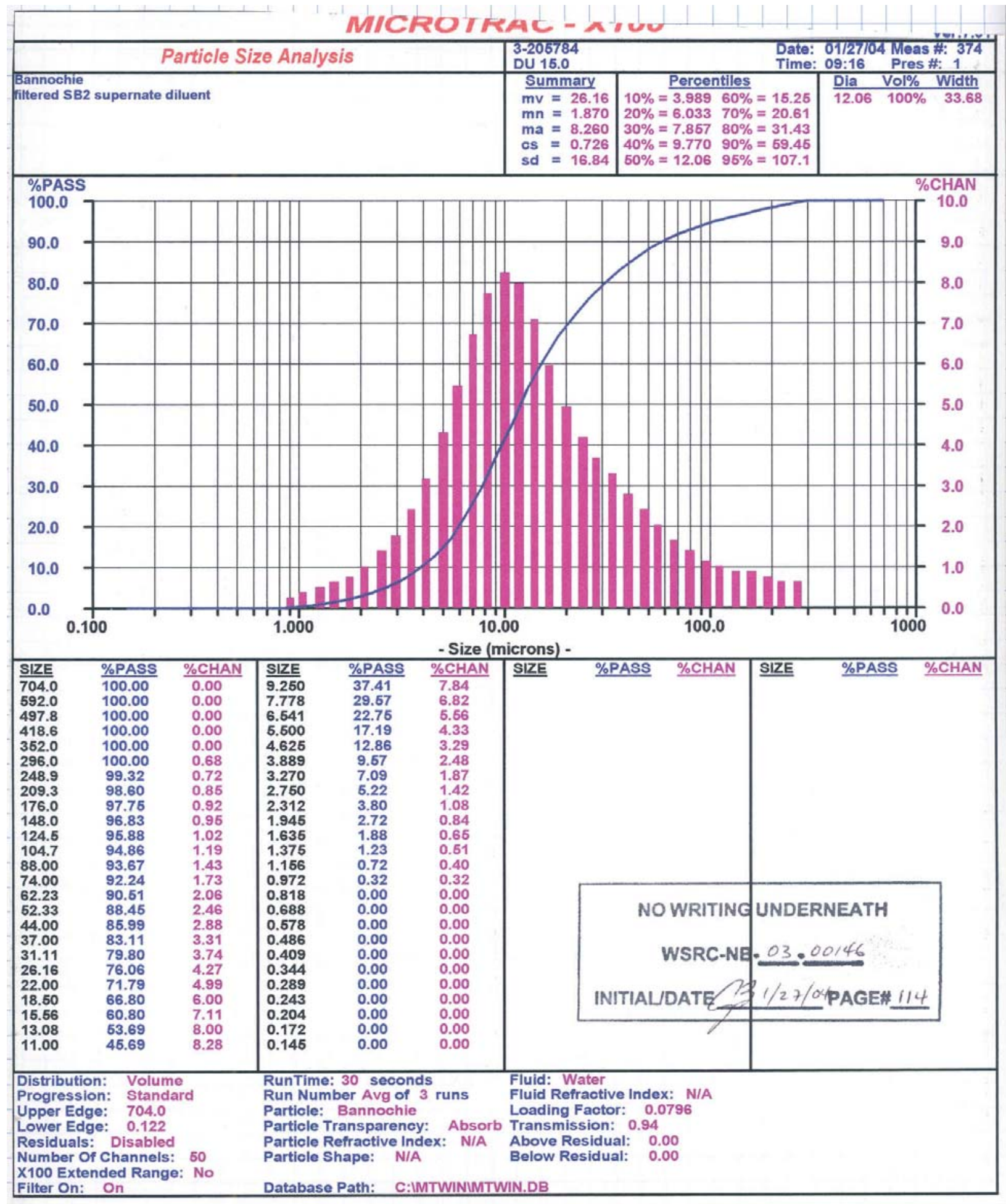

Figure C- 23. Particle size volume distribution for SB2 simulant with 15 wt \% uranium 
WSRC-TR-2004-00206

Revision 0

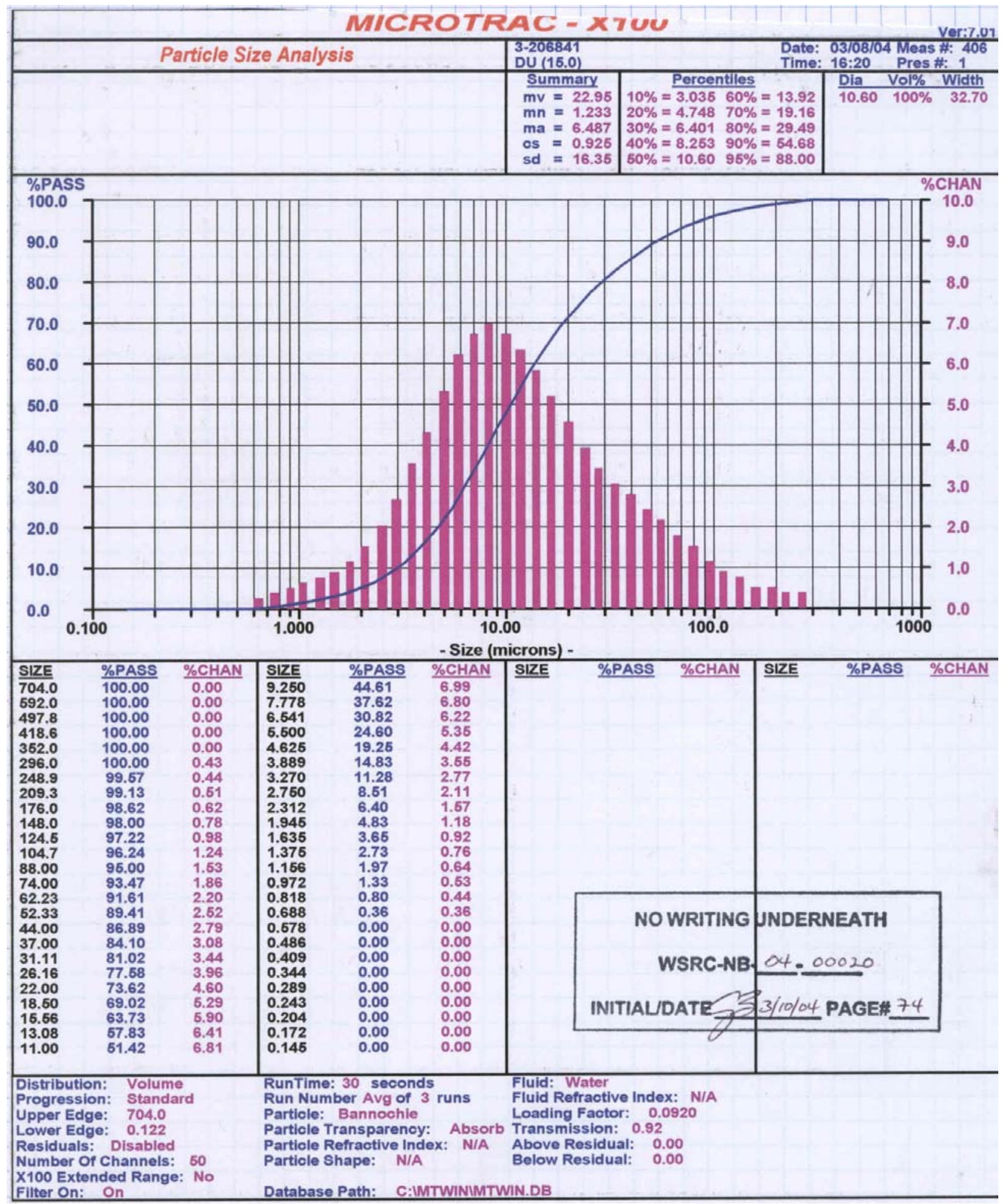

Figure C- 24. Particle size volume distribution for SB2 simulant with $15 \mathrm{wt} \%$ uranium following SRAT cycle processing 
WSRC-TR-2004-00206

Revision 0

This page intentionally left blank. 
WSRC-TR-2004-00206

Revision 0

\section{APPENDIX D. SRAT FEED RHEOGRAMS}


Key:

Black/gray $=$ initial up/down ramp flow curves

Blue/Teal = replicate up/down ramp flow curves

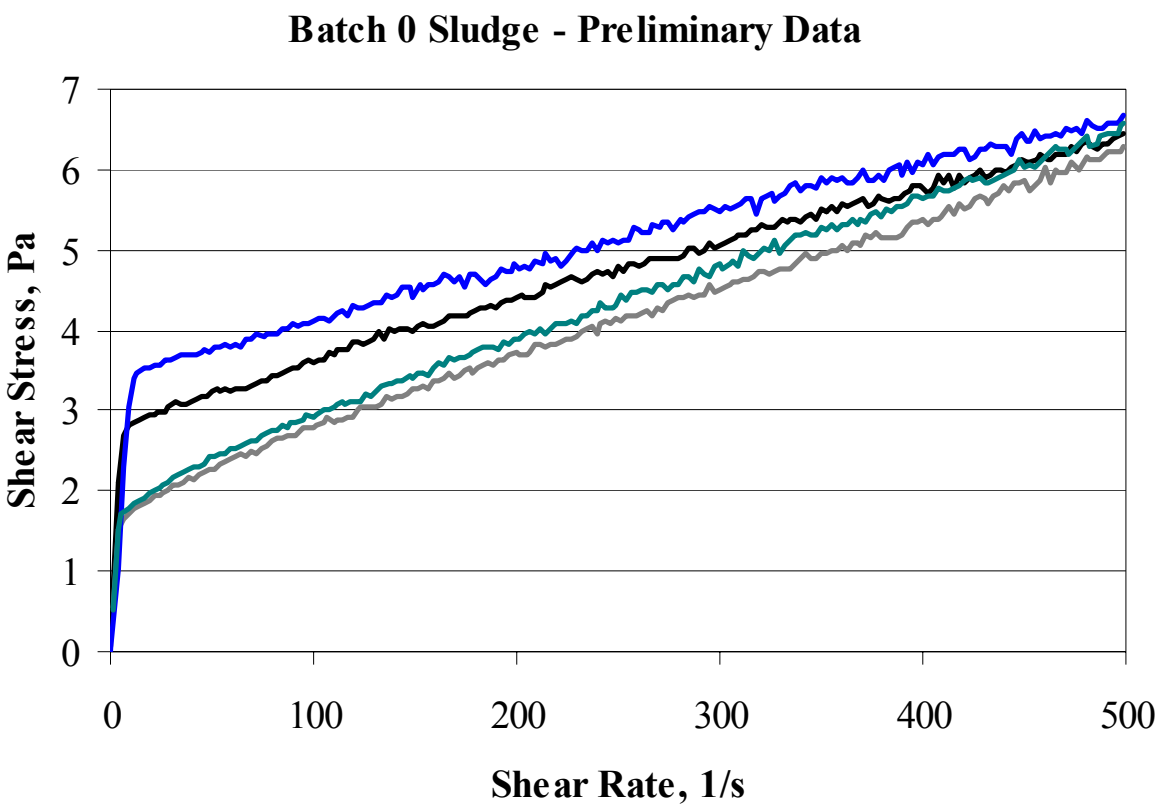

$-0 \mathrm{Up}-1 / 22-0$ Down-1/22 $-0 \mathrm{Up}-1 / 26-0$ Down-1/26

Figure D- 1. Preliminary Batch 0 Sludge Rheology Data

Batch 0 Sludge - Pre-run Data

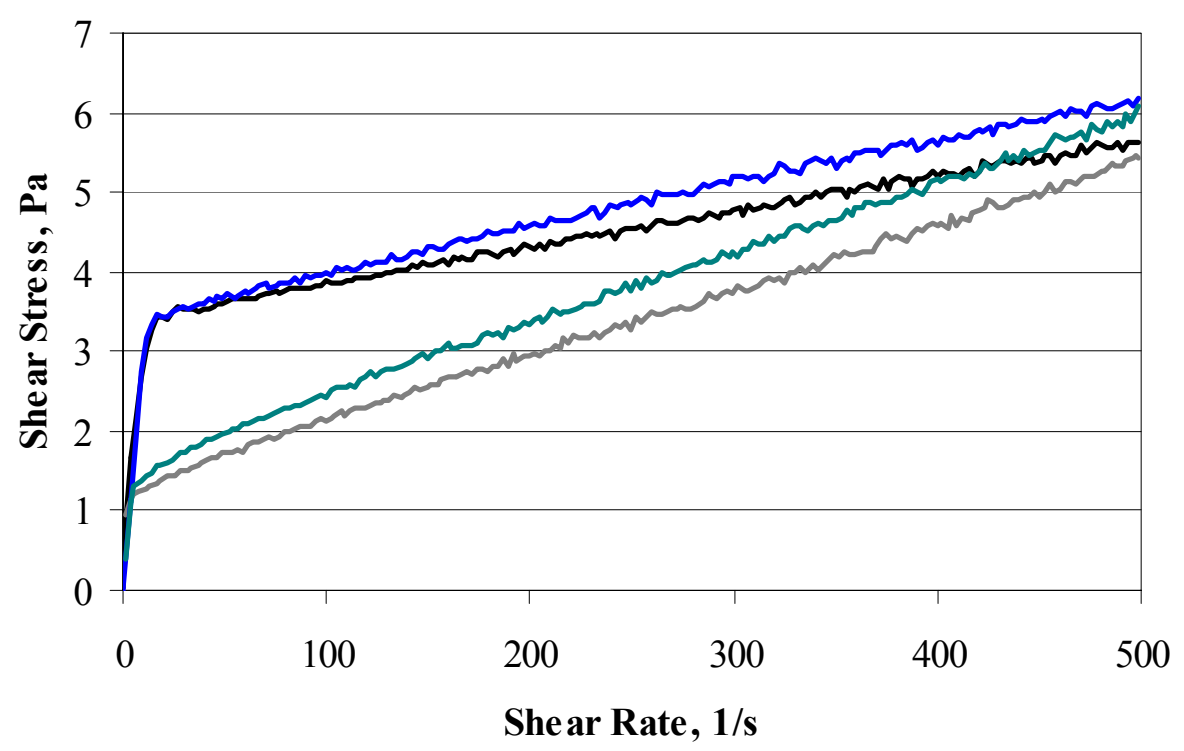

$0 \mathrm{Up}-2 / 17 \mathrm{a}-0$ Down-2/17a $-0 \mathrm{Up}-2 / 17 \mathrm{~b}-0$ Down-2/17b

Figure D- 2. Pre-Run Batch 0 Sludge Rheology Data 
Batch 3.75 Sludge - Preliminary Data

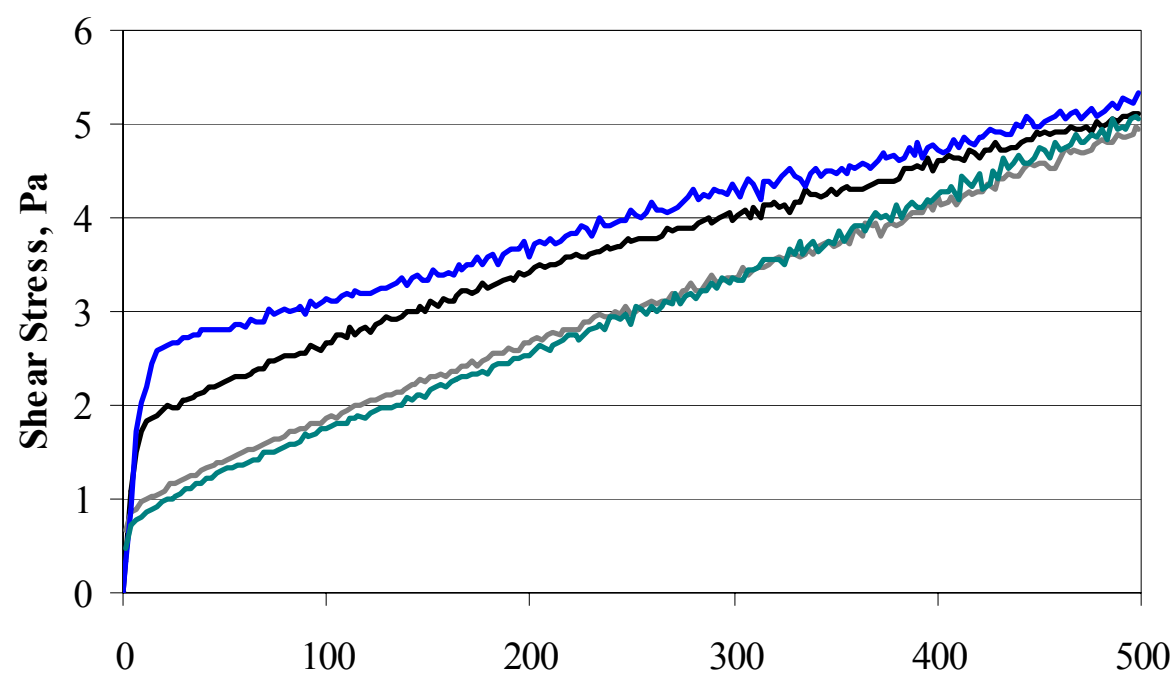

She ar Rate, 1/s

$\begin{array}{ll}-3.75 \text { Up-1/22 } & -3.75 \text { Down-1/22 } \\ -3.75 \text { Up-1/26 } & -3.75 \text { Down-1/26 }\end{array}$

Figure D- 3. Preliminary Batch 3.75 Sludge Rheology Data

Batch 3.75 Sludge - Pre-run Data

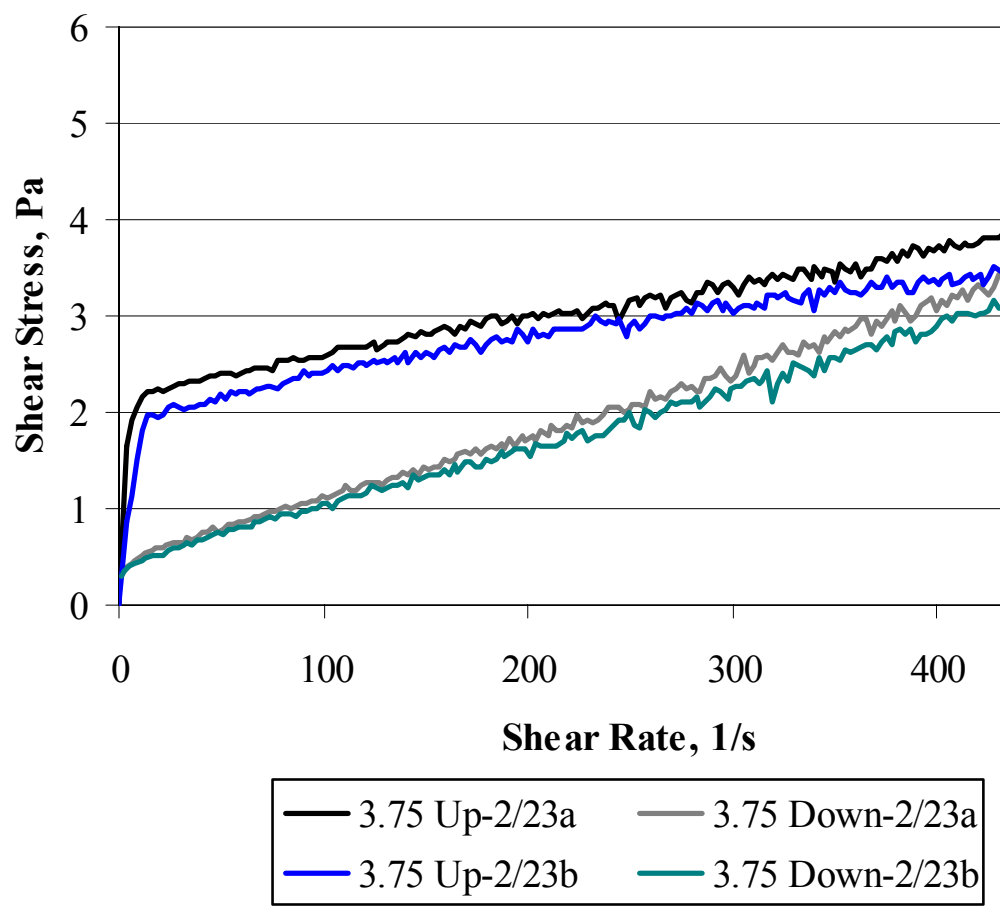

Figure D- 4. Pre-Run Batch 3.75 Sludge Rheology Data 
Batch 7.5i Sludge - Preliminary Data

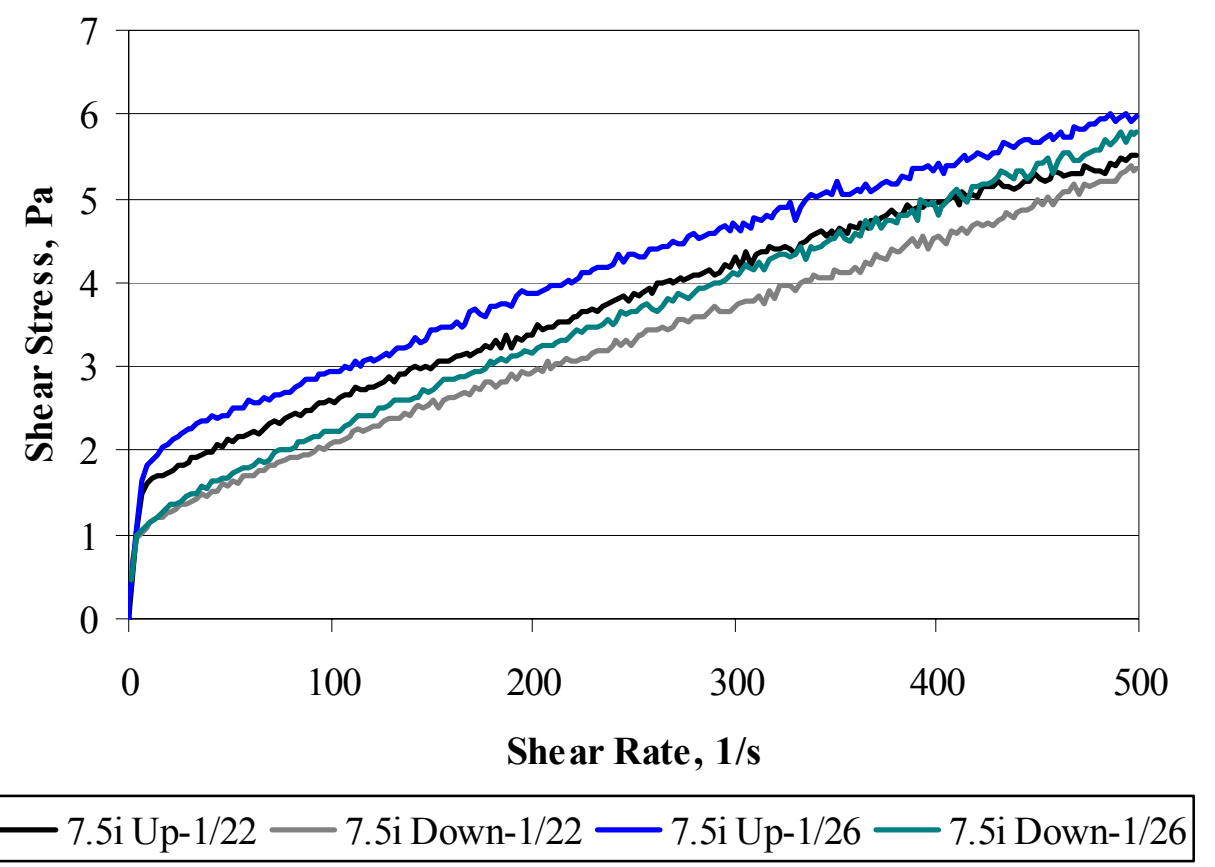

Figure D- 5. Preliminary Batch 7.5i Sludge Rheology Data

Batch 7.5i Sludge - Pre-run Data

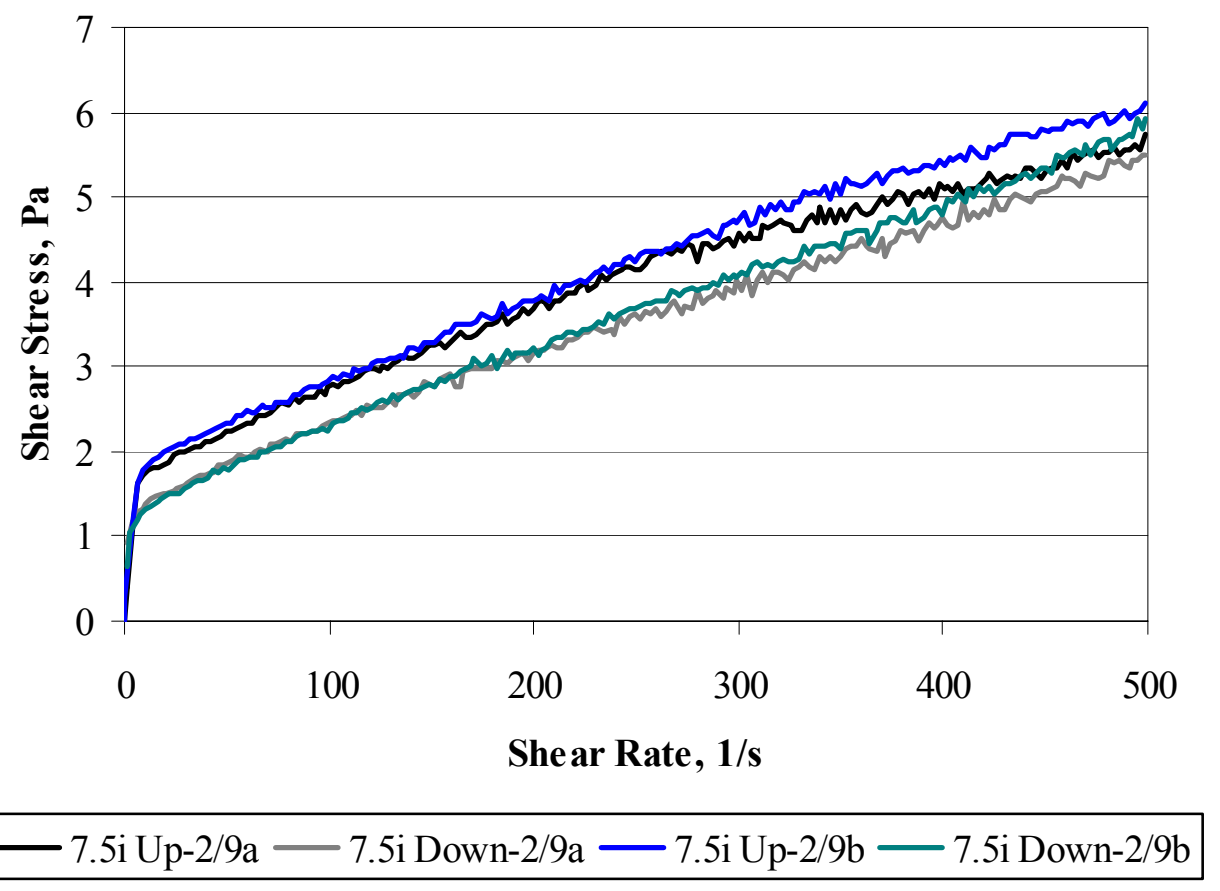

Figure D- 6. Pre-Run Batch 7.5i Sludge Rheology Data 


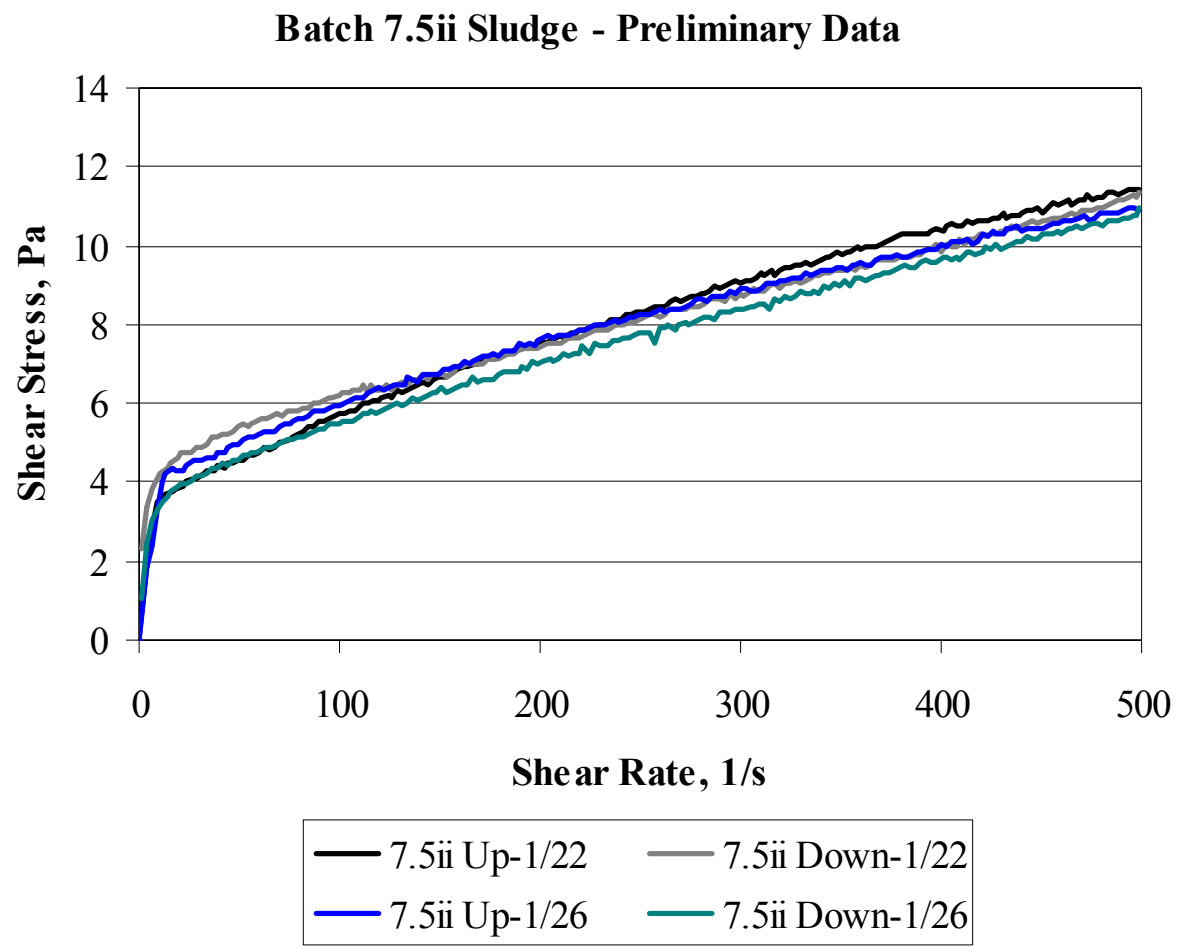

Figure D- 7. Preliminary Batch 7.5ii Sludge Rheology Data

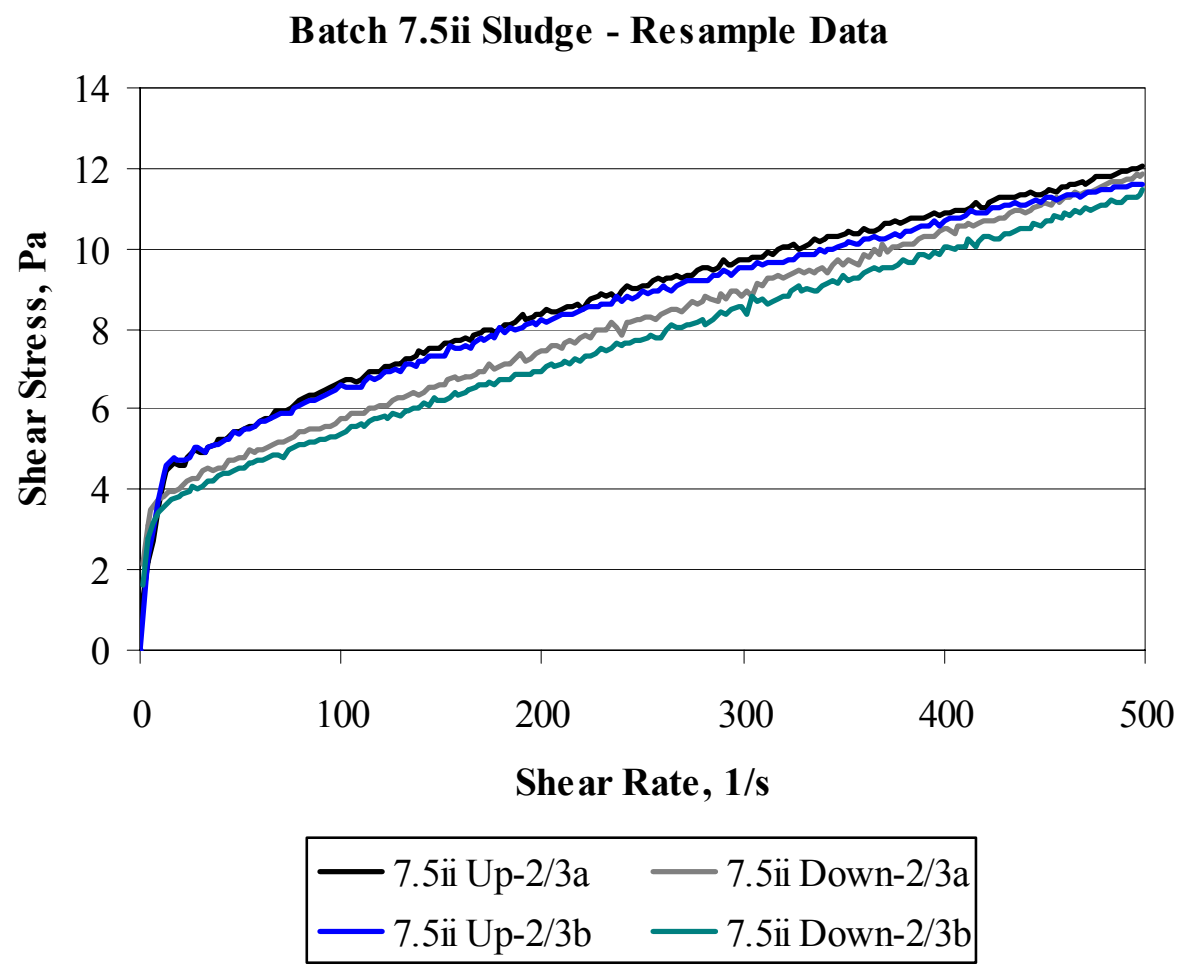

Figure D- 8. Resample Batch 7.5ii Sludge Rheology Data 


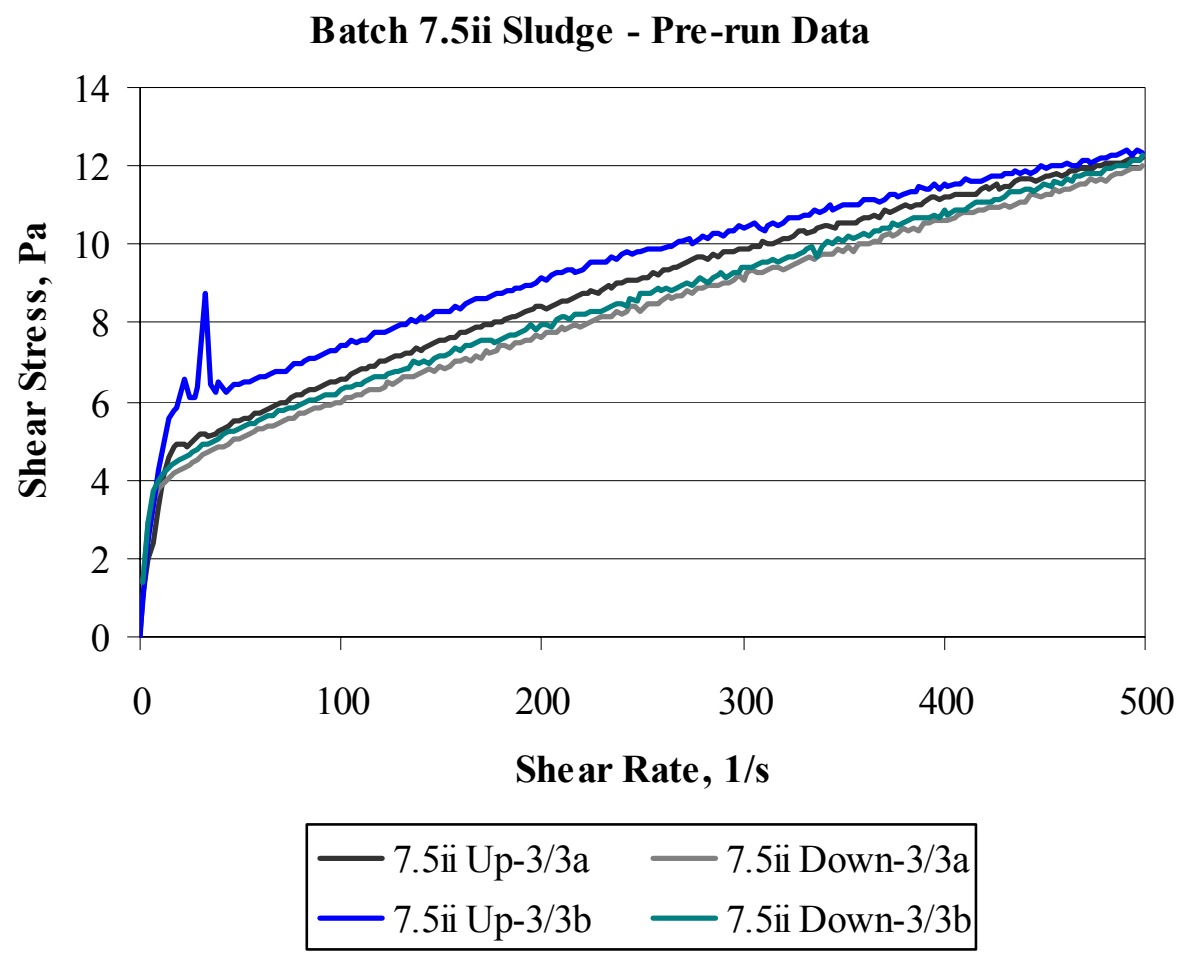

Figure D- 9. Pre-Run Batch 7.5ii Sludge Rheology Data 


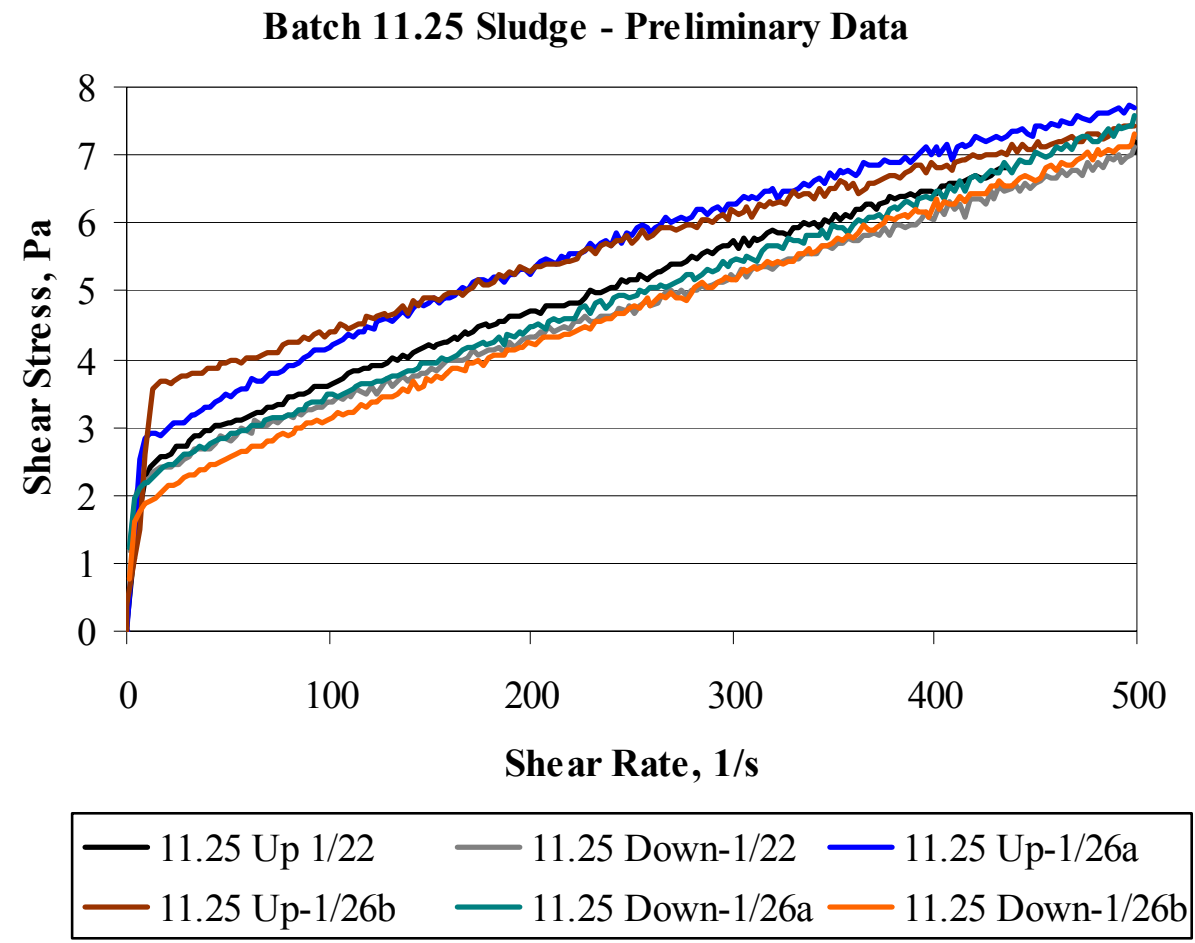

Figure D- 10. Preliminary Batch 11.25 Sludge Rheology Data

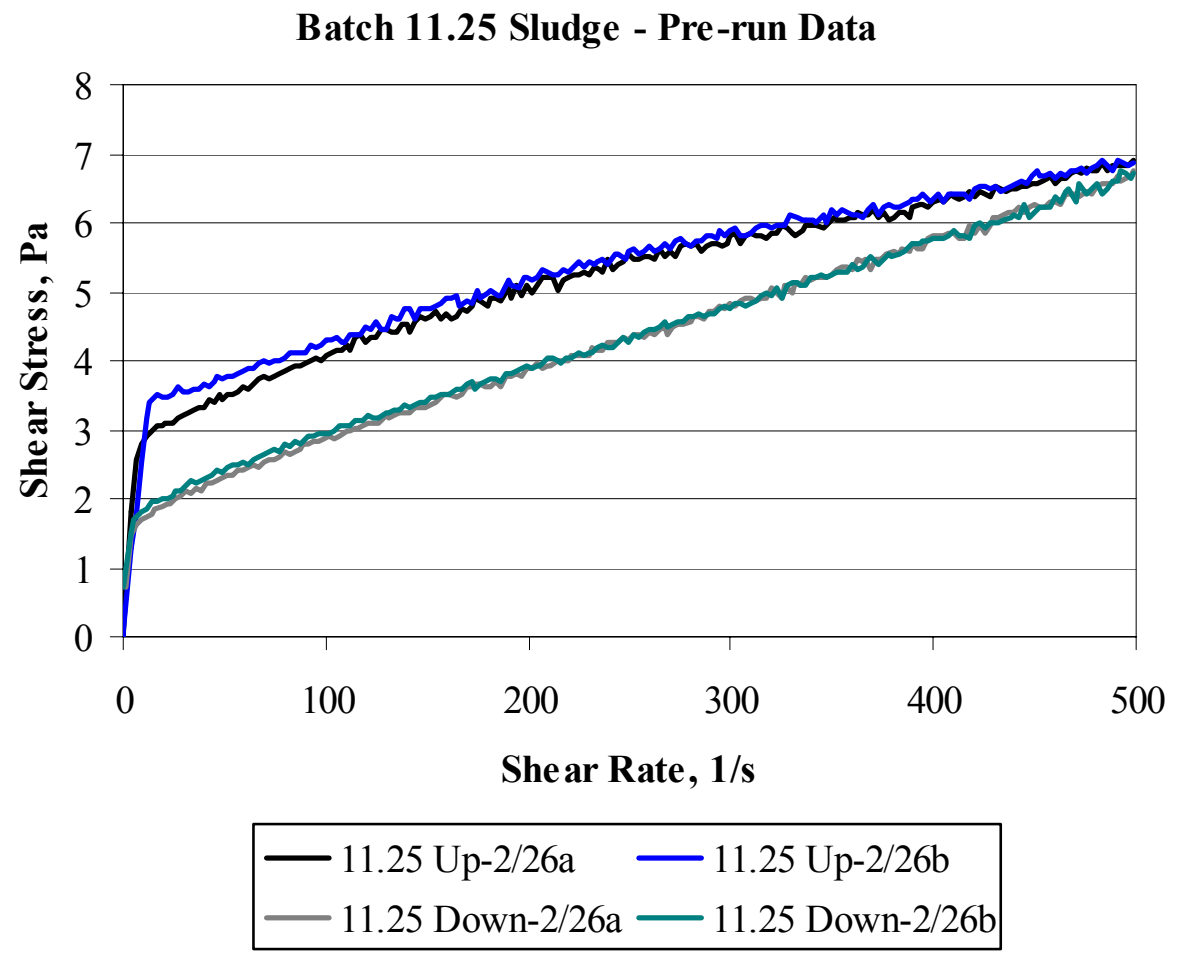

Figure D- 11. Pre-Run Batch 11.25 Sludge Rheology Data 


\section{Batch 15 Sludge - Pre liminary Data}

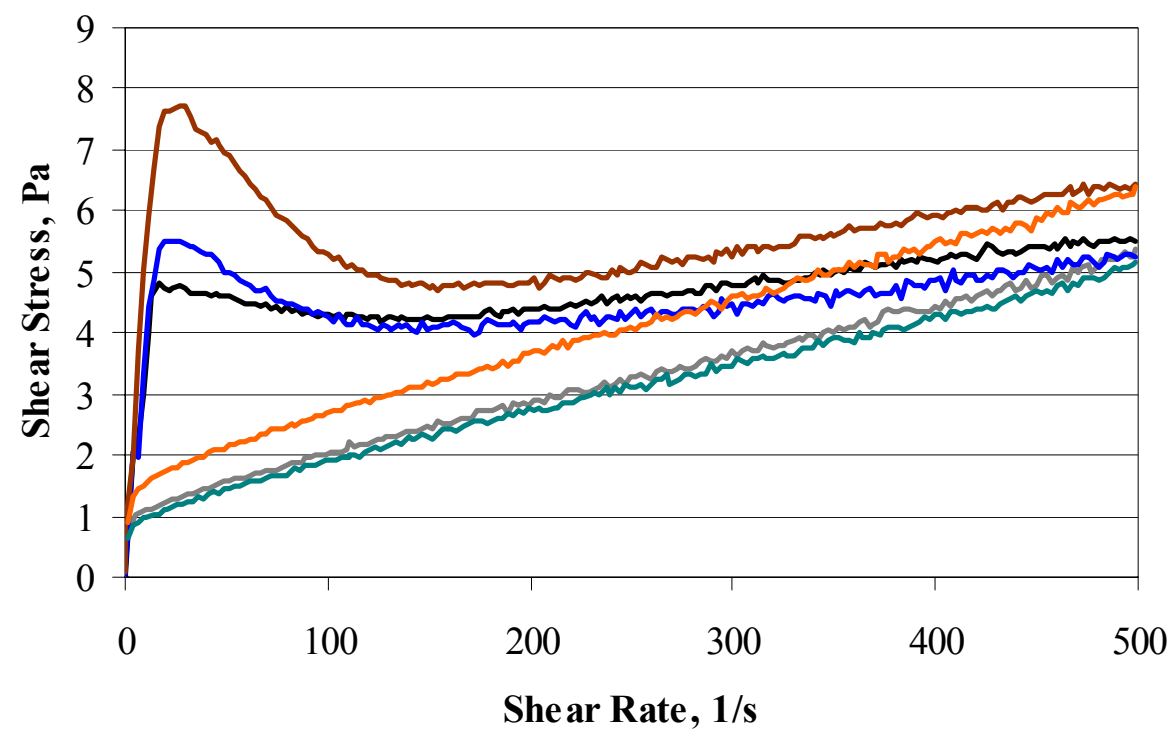

\begin{tabular}{|c|c|}
\hline $\begin{array}{l}-15 \mathrm{Up}-1 / 22 \\
-15 \mathrm{Up}-1 / 26 \mathrm{~b}\end{array}$ & $\begin{array}{l}-15 \text { Down- } 1 / 22-15 \text { Up-1/26a } \\
-15 \text { Down- } 1 / 26 \mathrm{a}-15 \text { Down- } 1 / 26 \mathrm{~b}\end{array}$ \\
\hline
\end{tabular}

Figure D- 12. Preliminary Batch 15 Sludge Rheology Data

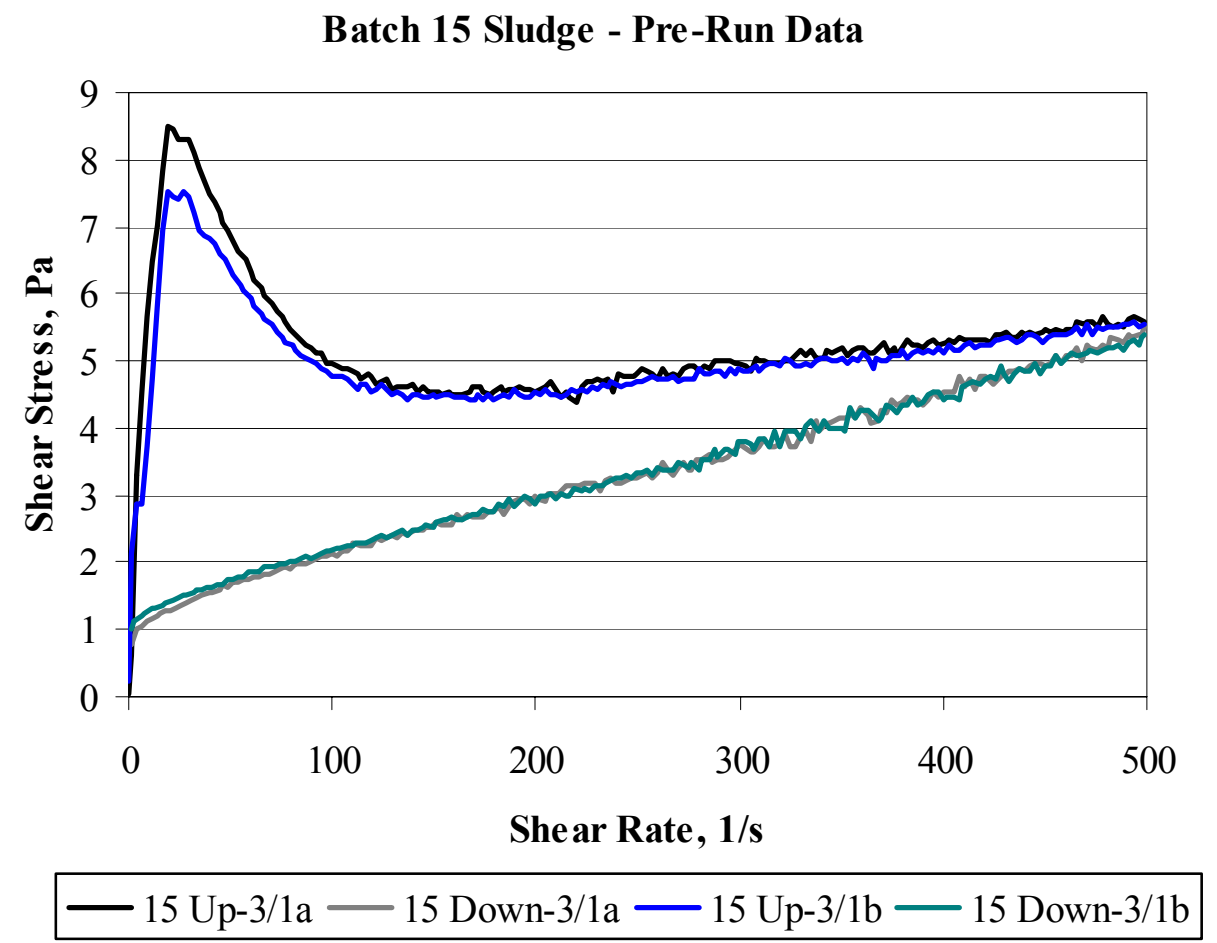

Figure D- 13. Pre-Run Batch 15 Sludge Rheology Data 
WSRC-TR-2004-00206

Revision 0

\section{APPENDIX E. SRAT FEED REGRESSION ANALYSES}


Key:

Green = up curve regressions

Red = down curve regressions

Batch 0 Sludge Regression - 1/22/04

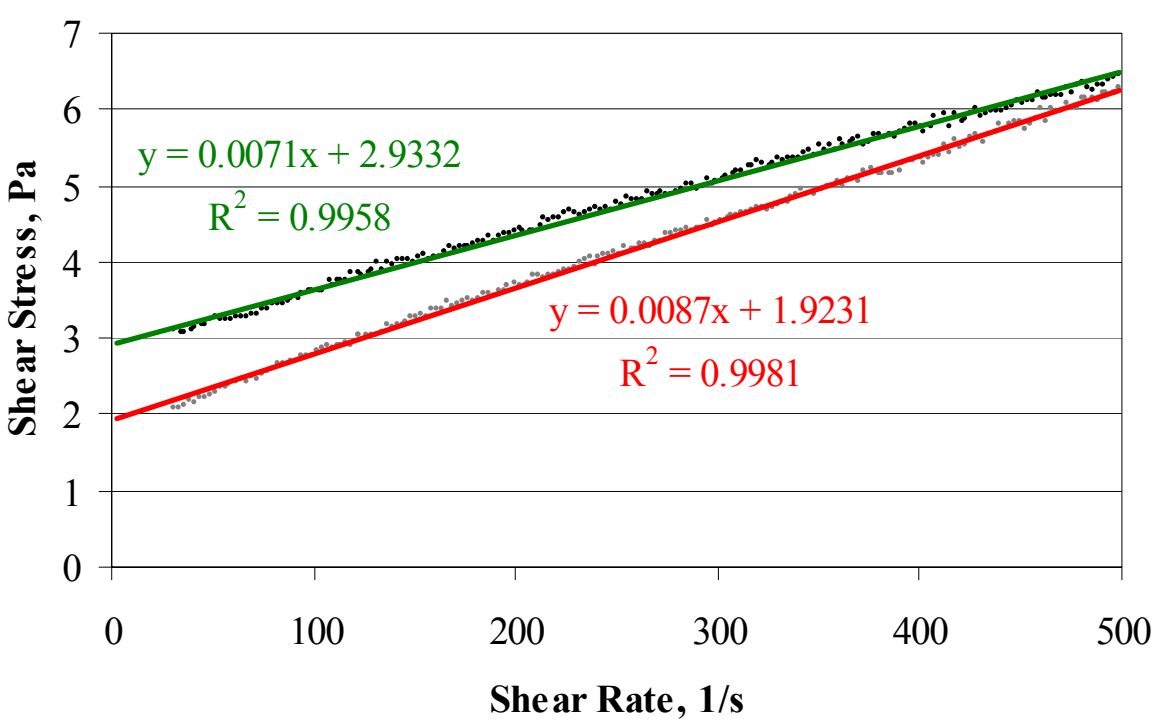

\begin{tabular}{ll}
$\cdot \begin{array}{l}\text { 0 Up-1/22 } \\
\text { Linear (0 Up-1/22) }\end{array} \quad$ Down-1/22 \\
\hline Linear (0 Down-1/22)
\end{tabular}

Figure E- 1. Batch 0 Sludge Regression - 1/22/04

Batch 0 Sludge Regression - 1/26/04

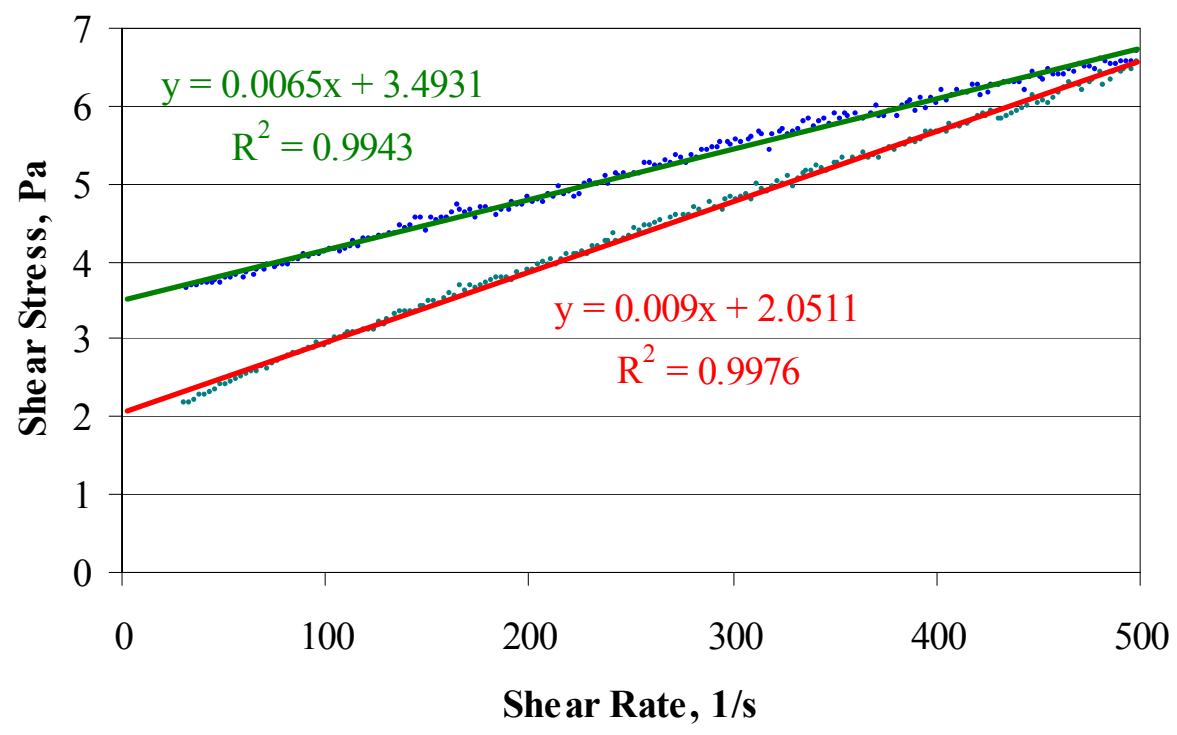

\begin{tabular}{|ll|}
\hline $0 \mathrm{Up}-1 / 26$ & 0 Down-1/26 \\
- Linear $(0 \mathrm{Up}-1 / 26)$ & - Linear (0 Down-1/26)
\end{tabular}

Figure E- 2. Batch 0 Sludge Regression - 1/26/04 
Batch 0 Sludge Regression - 2/17/04a

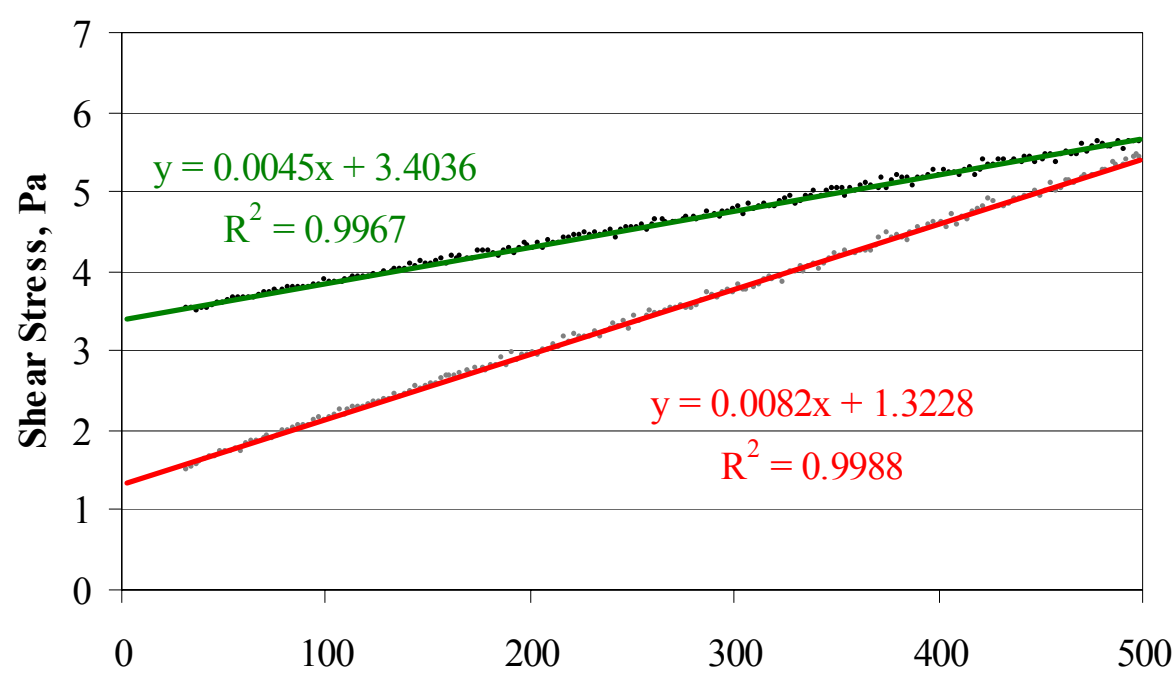

She ar Rate, $1 / \mathrm{s}$

\begin{tabular}{|ll|}
\hline 0 Up-2/17a & 0 Down-2/17a \\
- Linear (0 Up-2/17a) & Linear (0 Down-2/17a) \\
\hline
\end{tabular}

Figure E- 3. Batch 0 Sludge Regression - 2/17/04a

Batch 0 Sludge Regression - 2/17/04b

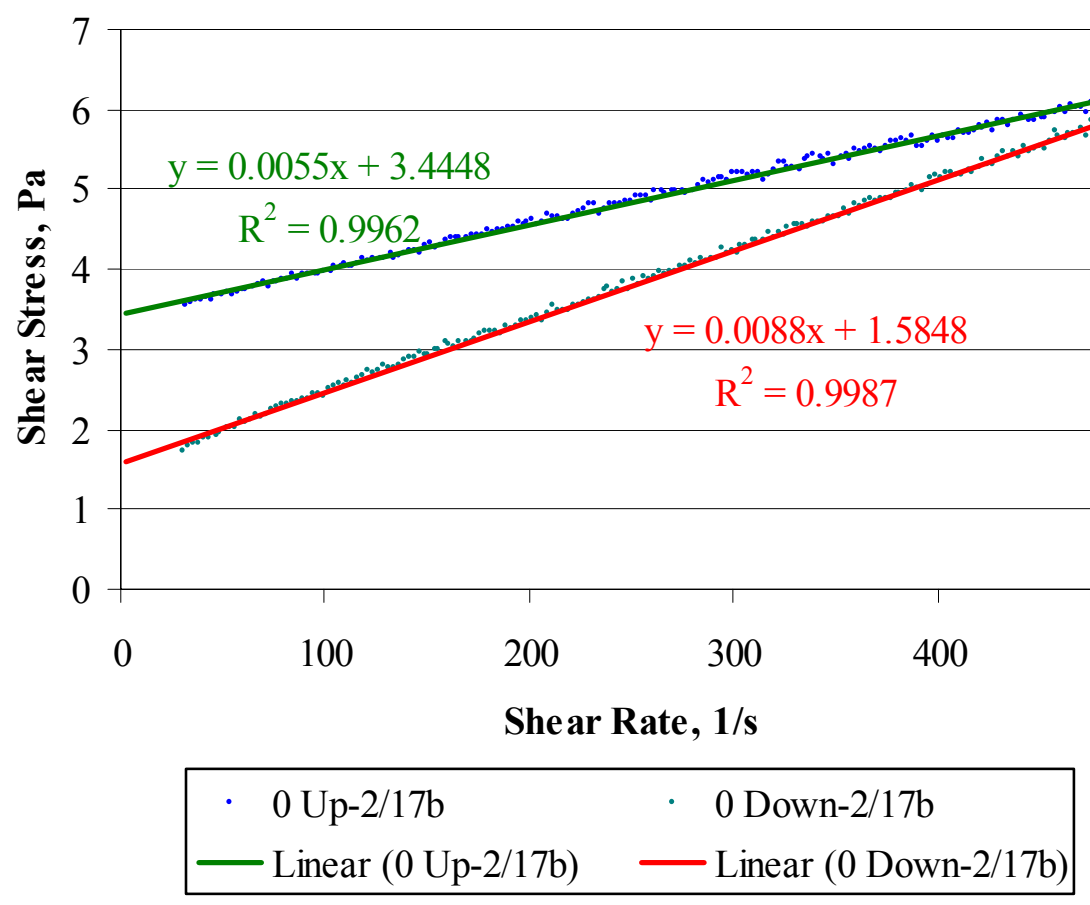

Figure E- 4. Batch 0 Sludge Regression - 2/17/04b 
Batch 3.75 Sludge Regression - 1/22/04

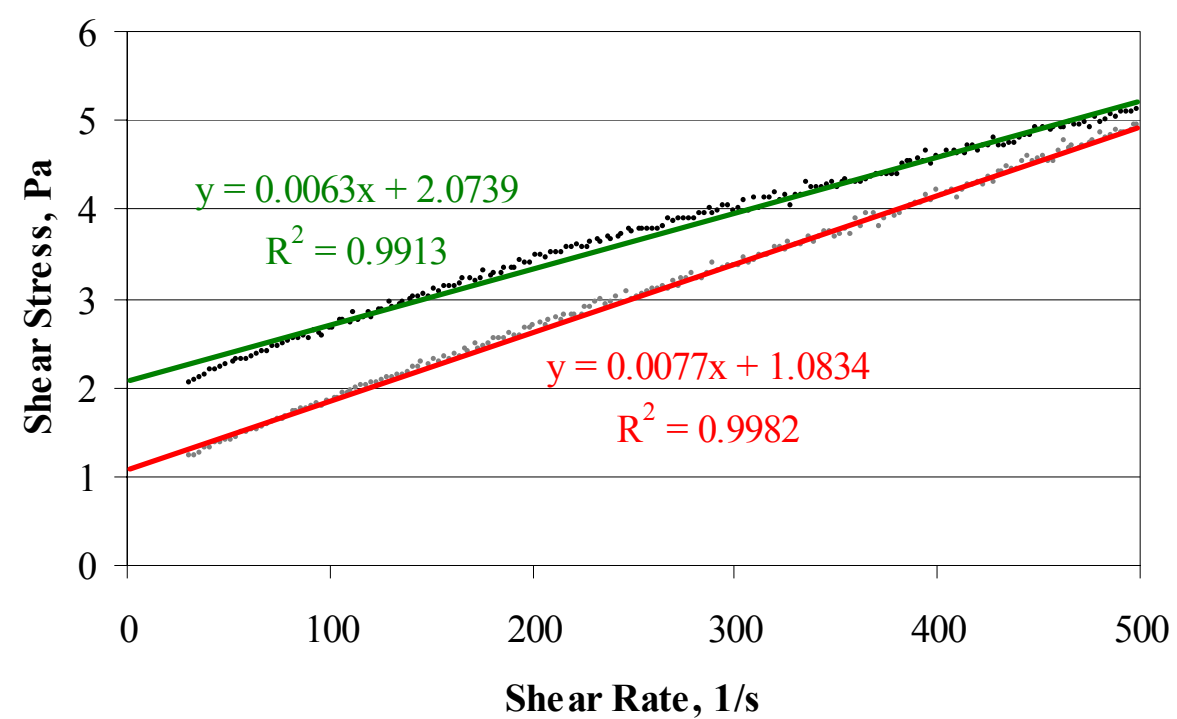

\begin{tabular}{|ll|}
\hline $\begin{array}{l}\cdot 3.75 \mathrm{Up}-1 / 22 \\
\text { Linear (3.75 Up-1/22) }\end{array}$ & 3.75 Down-1/22 \\
\hline & Linear (3.75 Down-1/22) \\
\hline
\end{tabular}

Figure E- 5. Batch 3.75 Sludge Regression - 1/22/04

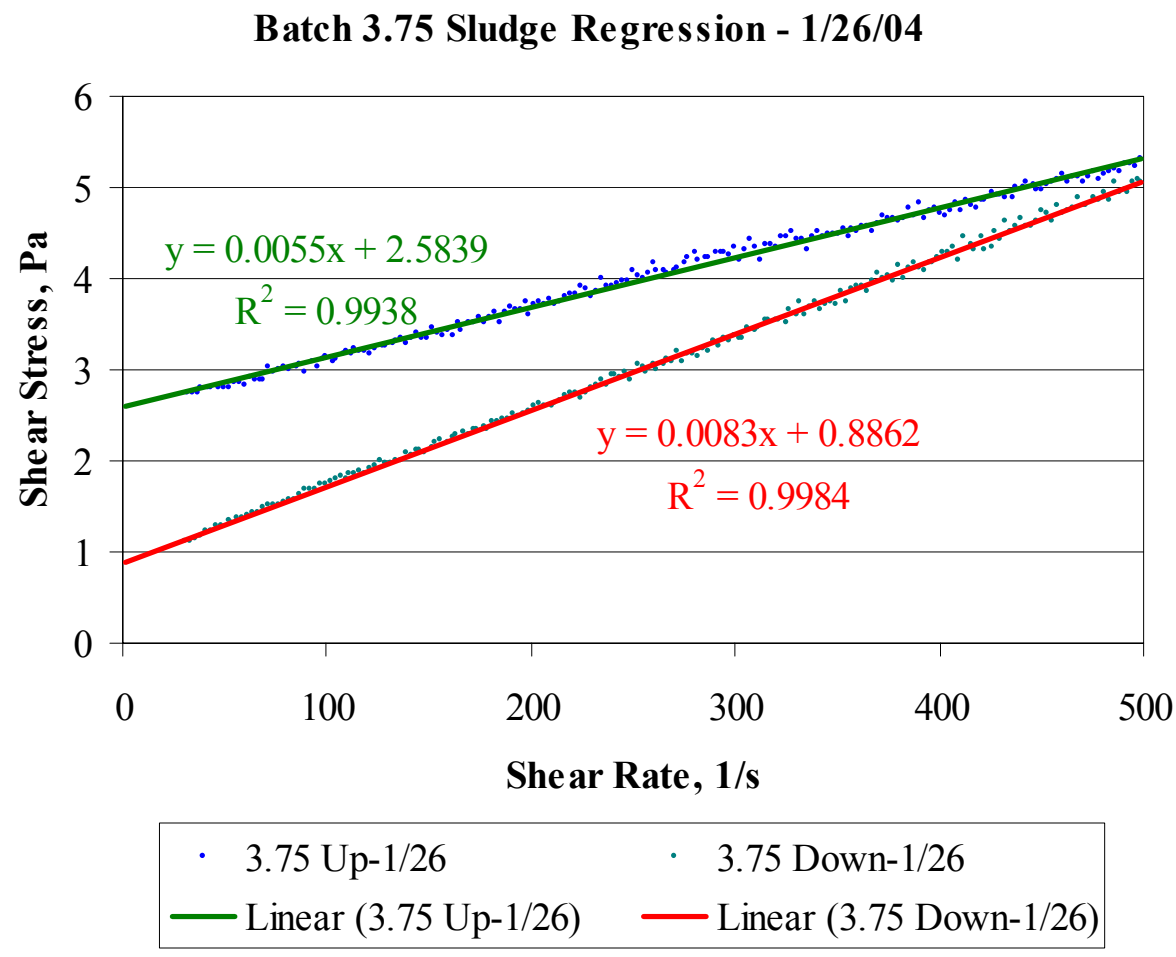

Figure E- 6. Batch 3.75 Sludge Regression - 1/26/04 
Batch 3.75 Sludge Regression - 2/23/04a

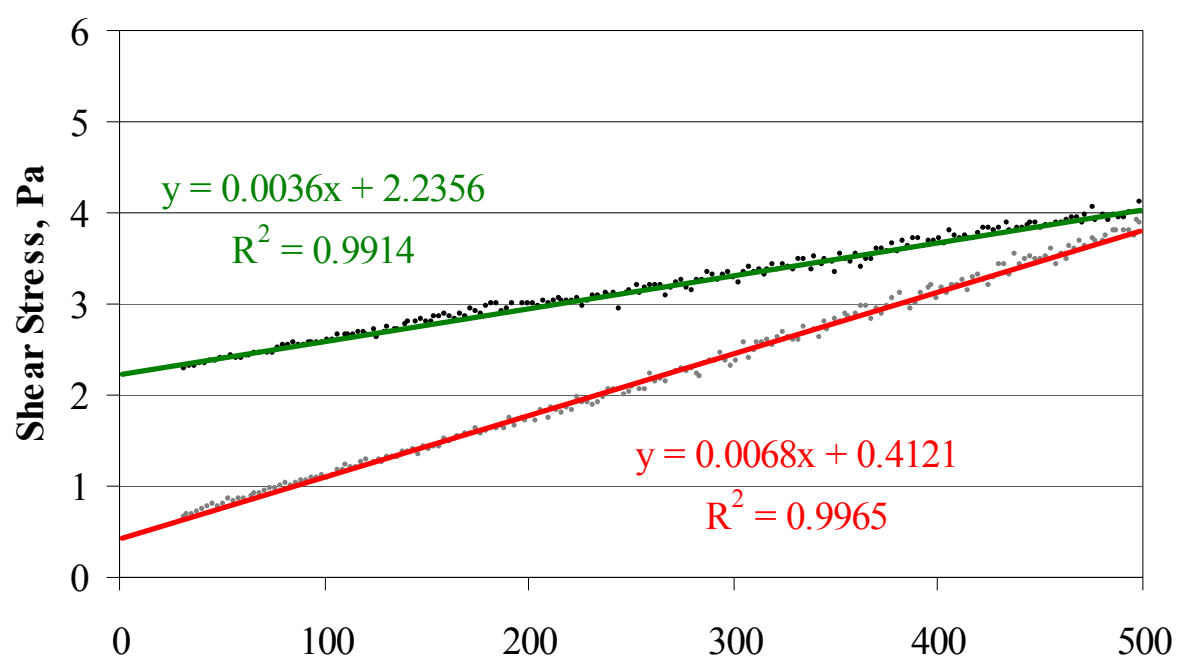

Shear Rate, $1 / \mathrm{s}$

\begin{tabular}{|ll|}
\hline $\begin{array}{l}\text { 3.75 Up-2/23a } \\
\text { Linear (3.75 Up-2/23a) }\end{array}$ & 3.75 Down-2/23a \\
\hline & Linear (3.75 Down-2/23a) \\
\hline
\end{tabular}

Figure E- 7. Batch 3.75 Sludge Regression - 2/23/04a

Batch 3.75 Sludge Regression - 2/23/04b

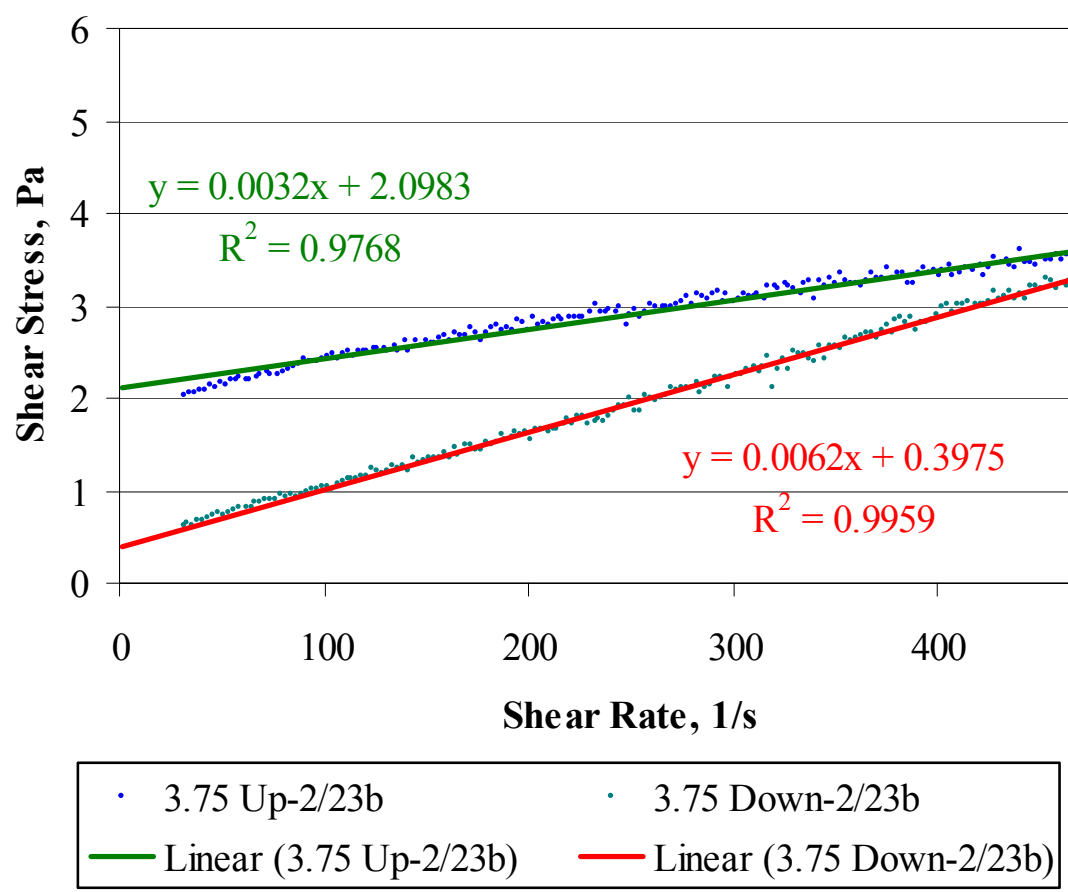

Figure E- 8. Batch 3.75 Sludge Regression - 2/23/04b 
Batch 7.5i Sludge Regression - 1/22/04

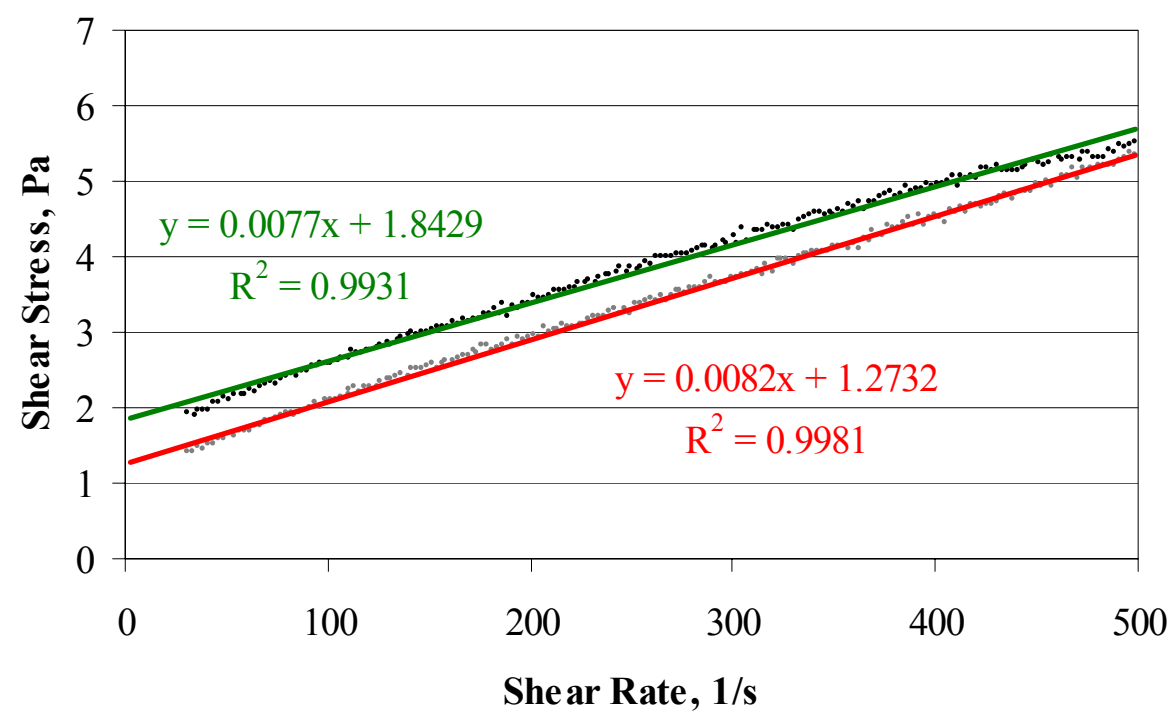

\begin{tabular}{|ll|}
\hline 7.5i Up-1/22 & 7.5i Down-1/22 \\
- Linear (7.5i Up-1/22) & — Linear (7.5i Down-1/22) \\
\hline
\end{tabular}

Figure E- 9. Batch 7.5i Sludge Regression - 1/22/04

Batch 7.5i Sludge Regression - 1/26/04

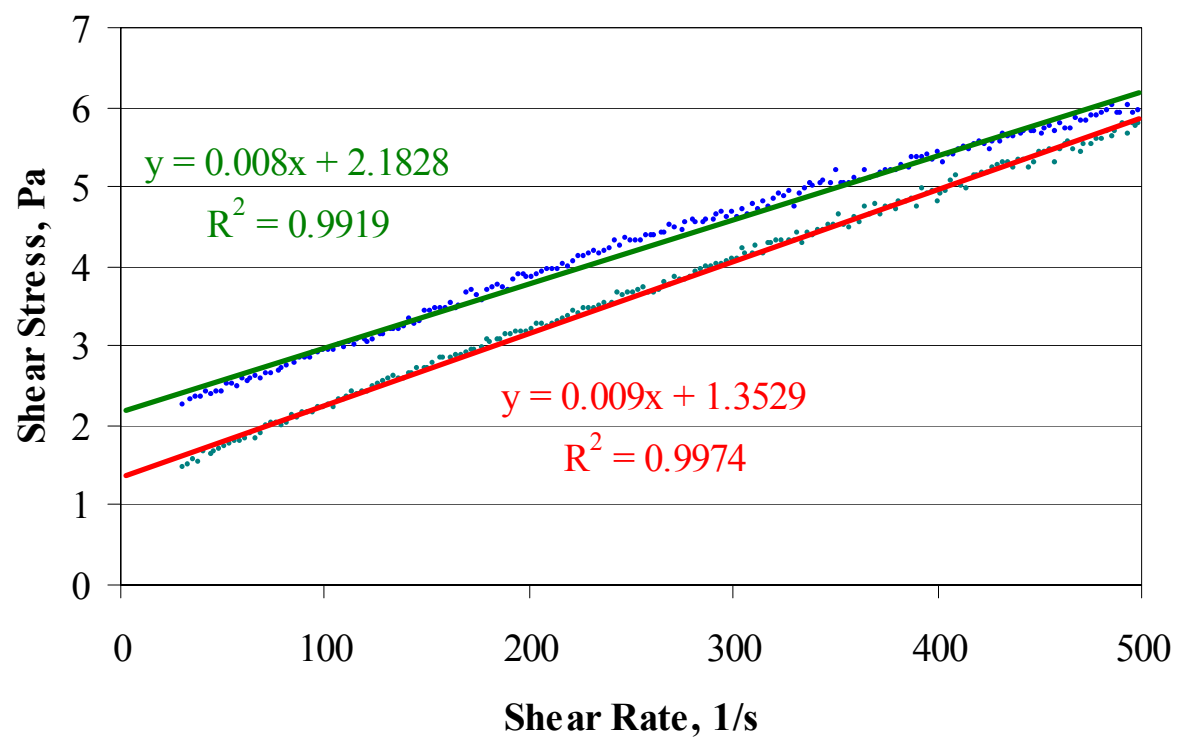

\begin{tabular}{|ll|}
\hline $\begin{array}{l}\text { 7.5i Up-1/26 } \\
\text { Linear (7.5i Up-1/26) }\end{array}$ & 7.5i Down-1/26 \\
\hline &
\end{tabular}

Figure E- 10. Batch 7.5i Sludge Regression - 1/26/04 
Batch 7.5i Sludge Regression - 2/9/04a

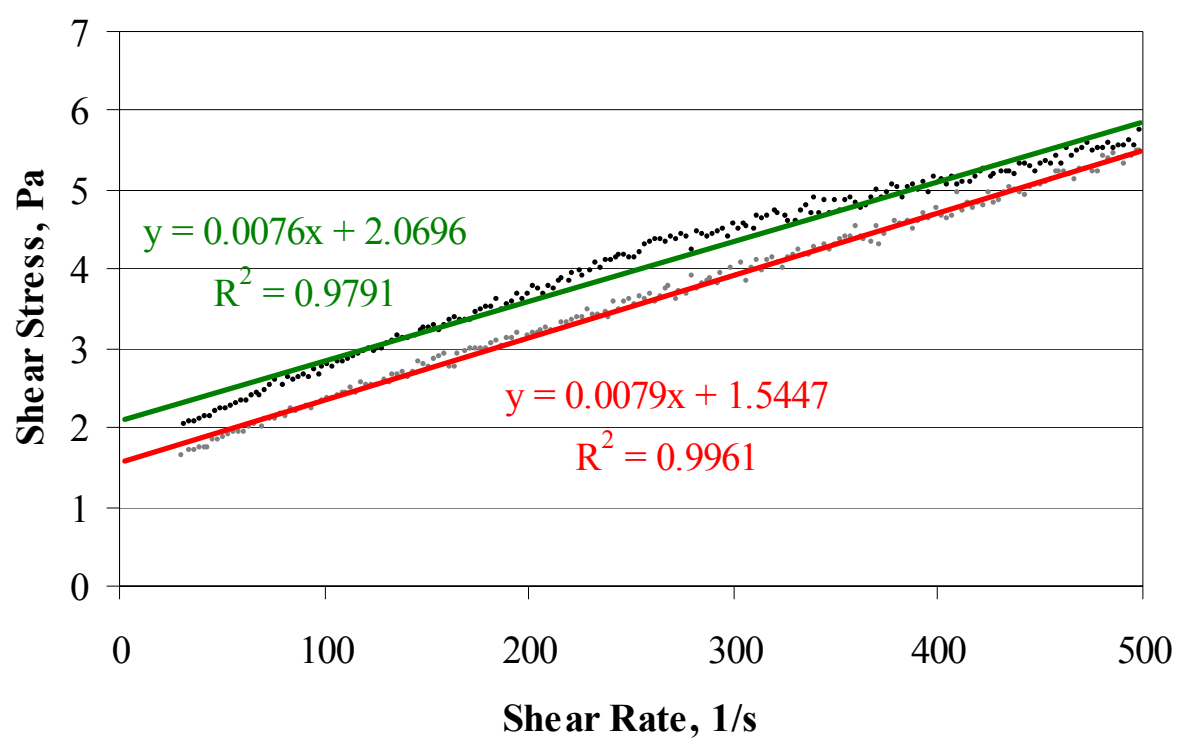

\begin{tabular}{|ll|}
\hline $\begin{array}{l}\cdot \\
\text { 7.5i Up-2/9a }\end{array}$ & 7.5i Down-2/9a \\
- Linear (7.5i Up-2/9a) & Linear (7.5i Down-2/9a) \\
\hline
\end{tabular}

Figure E- 11. Batch 7.5i Sludge Regression - 2/9/04a

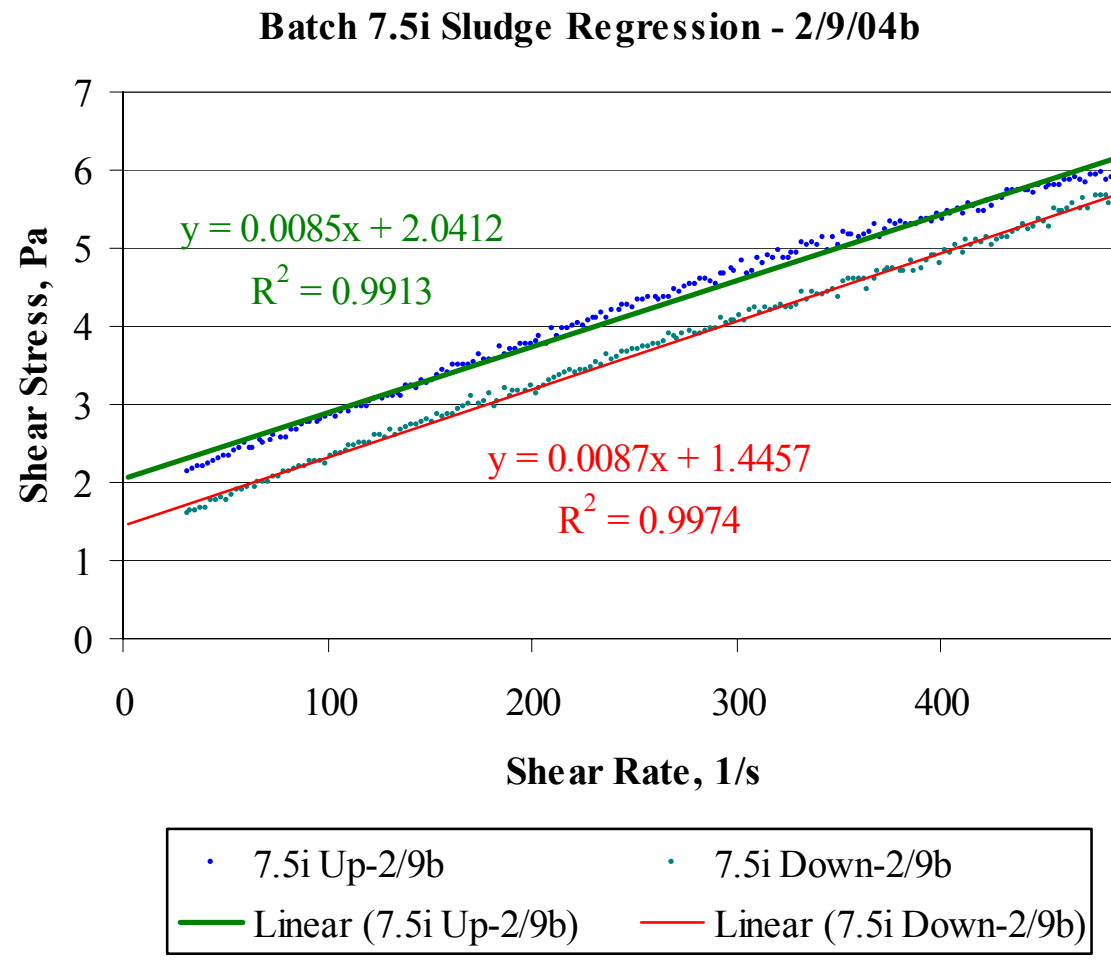

Figure E- 12. Batch 7.5i Sludge Regression - 2/9/04b 
Batch 7.5ii Sludge Regression - 1/22/04

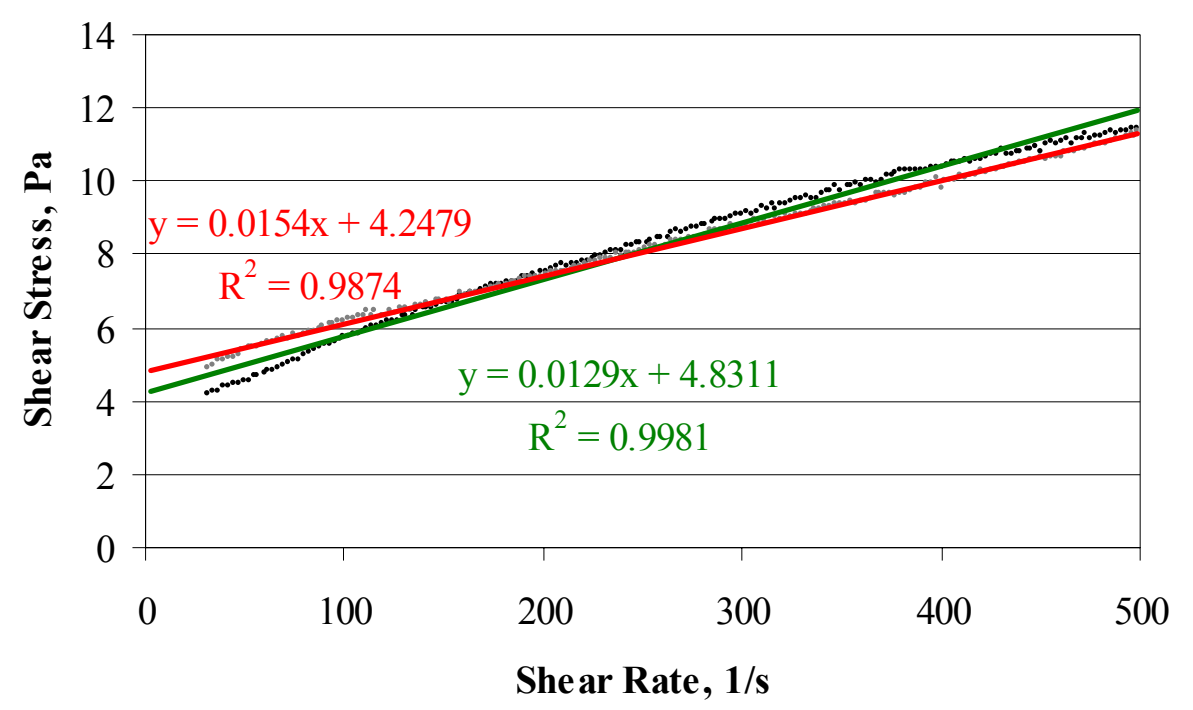

$\begin{array}{ll}\cdot \text { 7.5ii Up-1/22 } & \text { 7.5ii Down-1/22 } \\ - \text { Linear (7.5ii Up-1/22) } & \text { Linear (7.5ii Down-1/22) }\end{array}$

Figure E- 13. Batch 7.5ii Sludge Regression - 1/22/04

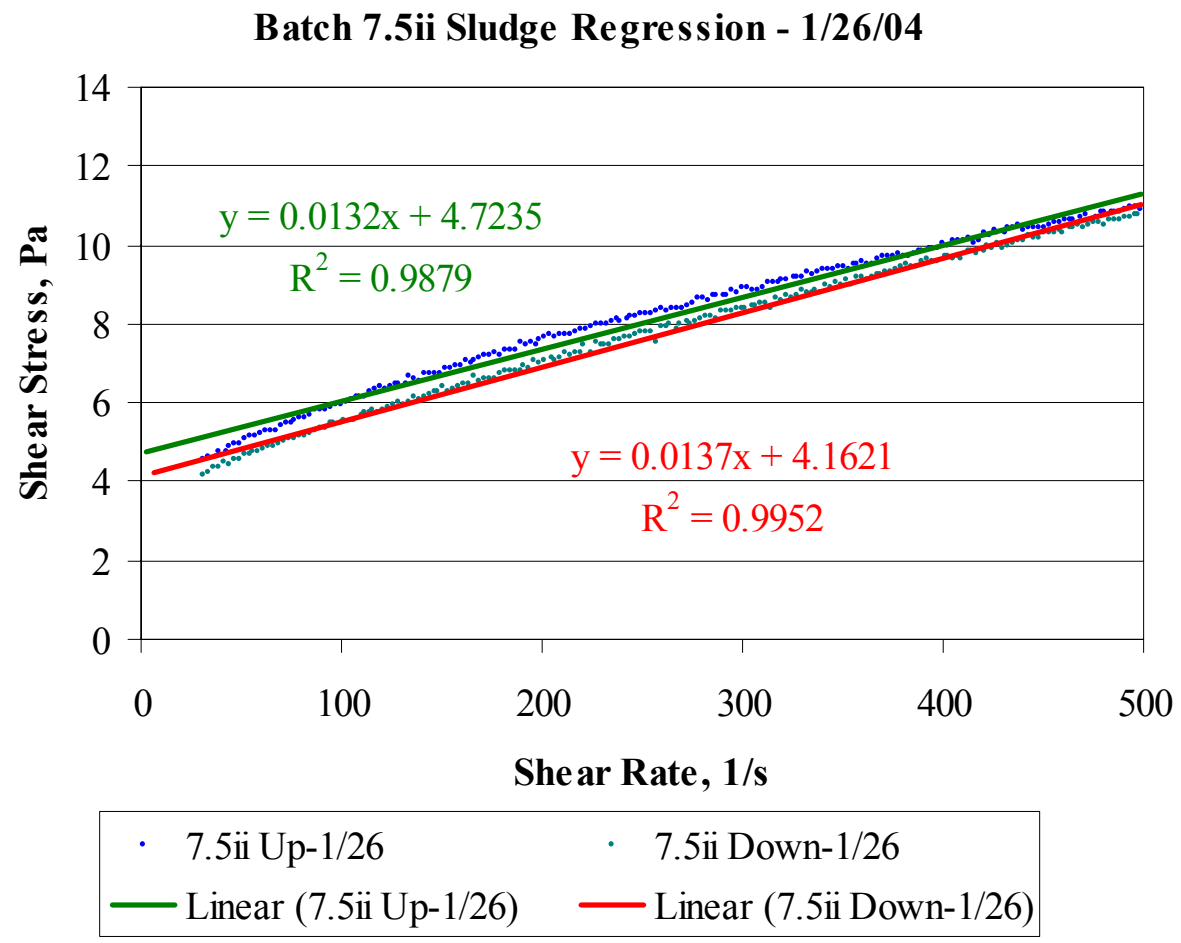

Figure E- 14. Batch 7.5ii Sludge Regression - 1/26/04 
Batch 7.5ii Sludge Regression - 2/3/04a

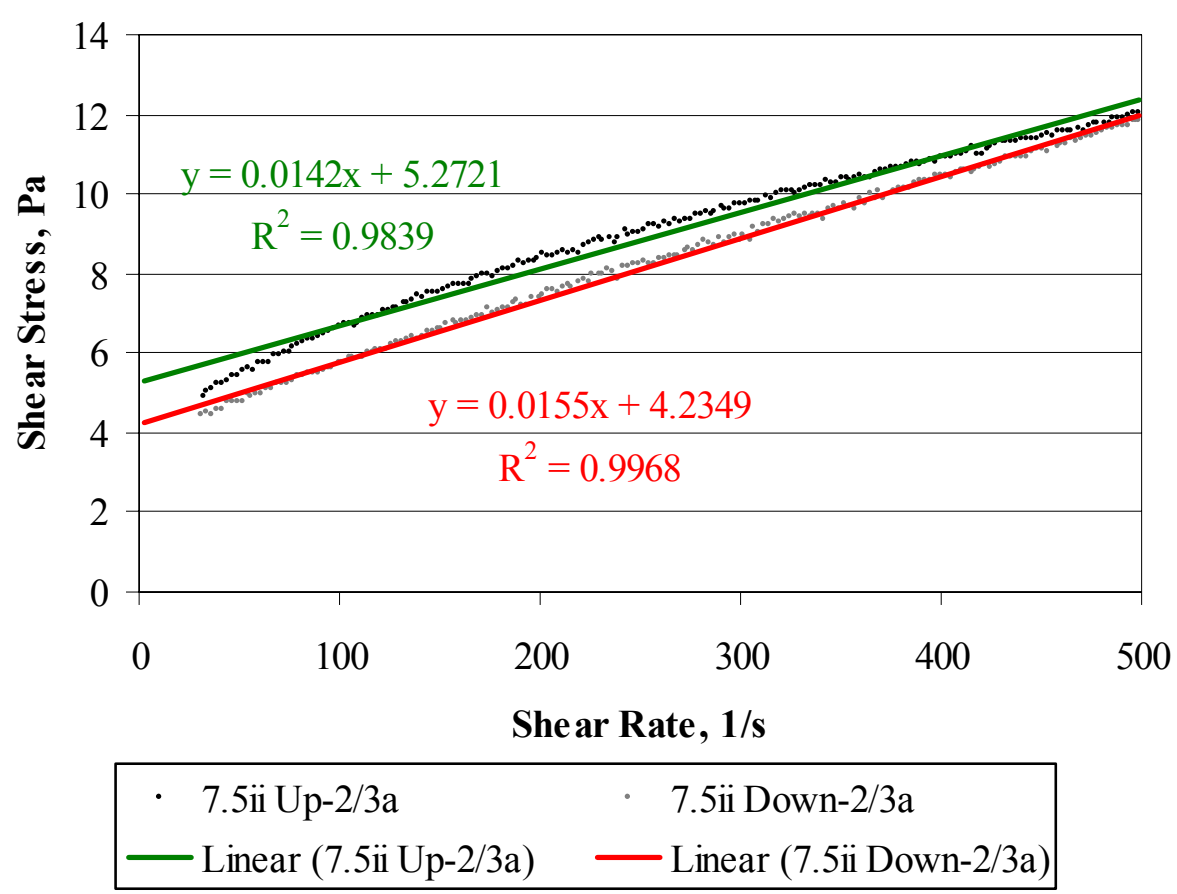

Figure E- 15. Batch 7.5ii Sludge Regression - 2/3/04a

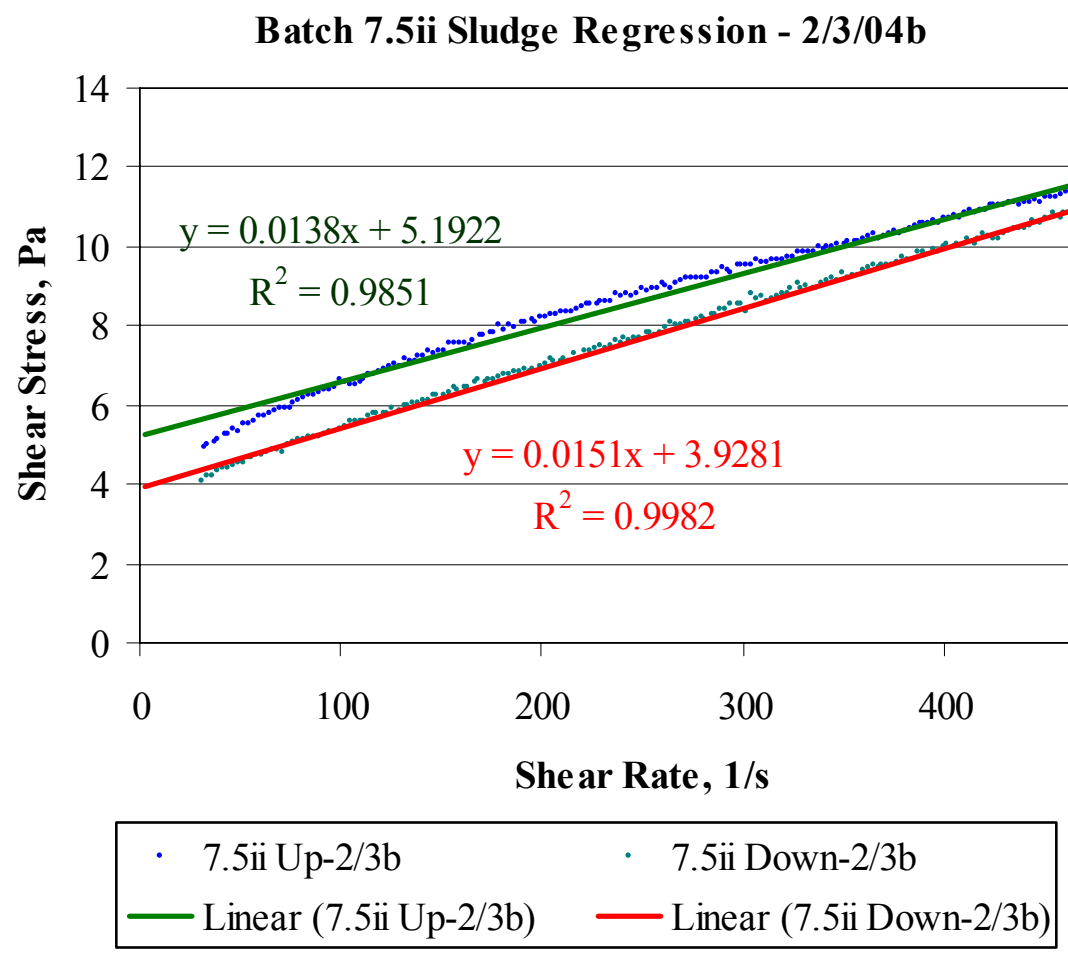

Figure E- 16. Batch 7.5ii Sludge Regression - 2/3/04b 
Batch 7.5ii Sludge Regression - 3/3/04a

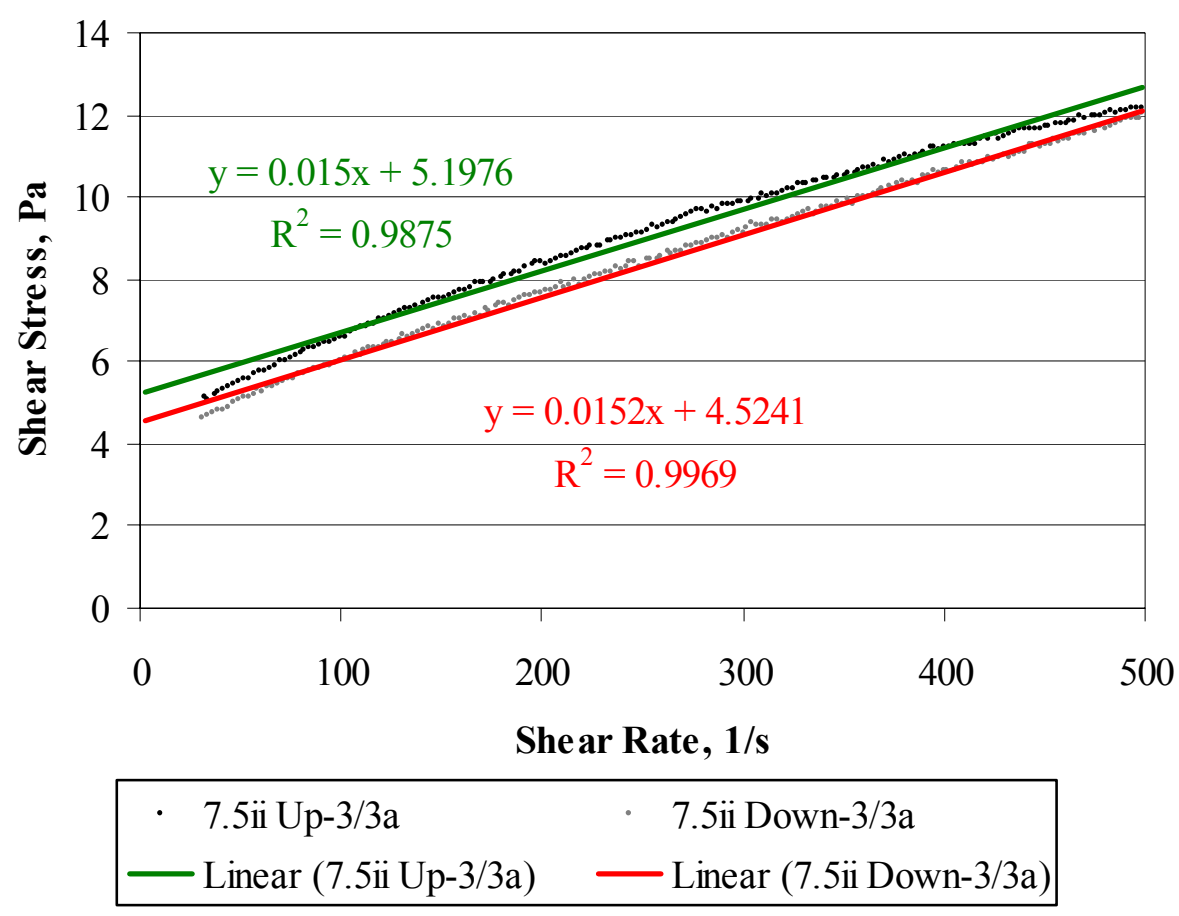

Figure E- 17. Batch 7.5ii Sludge Regression - 3/3/04a

Batch 7.5ii Sludge Regression - 3/3/04b

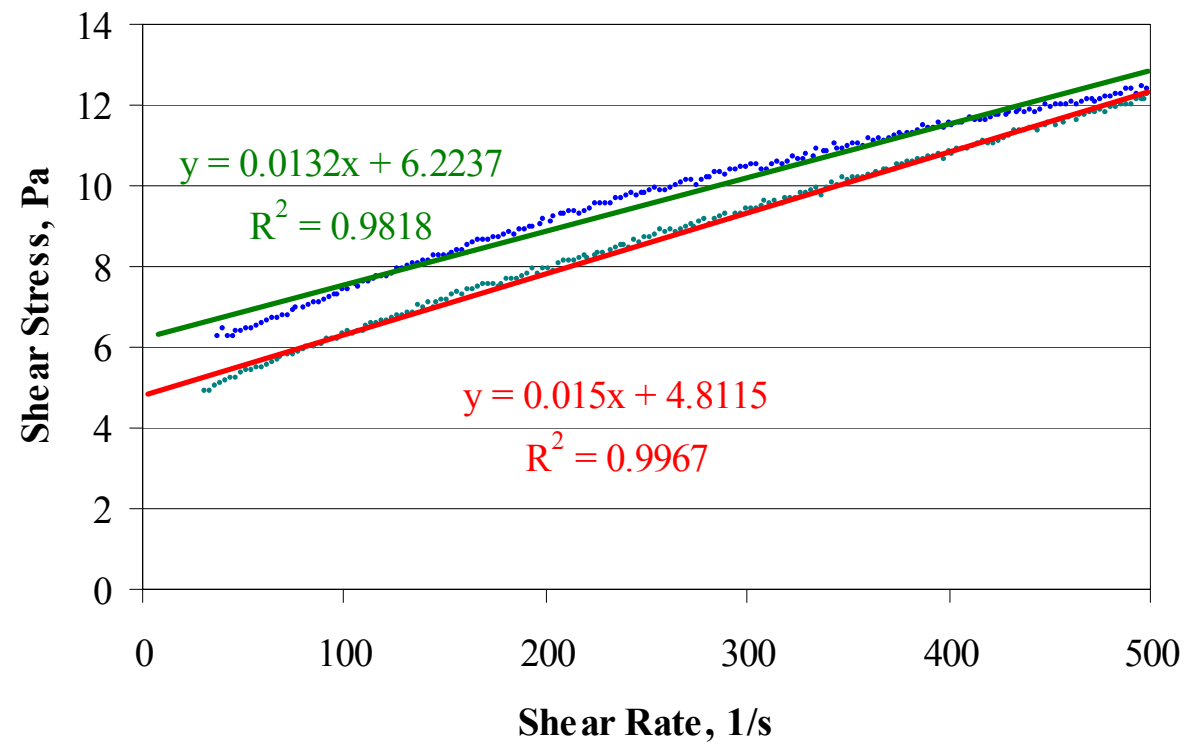

\begin{tabular}{|cc|}
\hline $\begin{array}{c}\text { 7.5ii Up-3/3b } \\
\text { Linear (7.5ii Up-3/3b) }\end{array}$ & 7.5ii Down-3/3b \\
\hline &
\end{tabular}

Figure E- 18. Batch 7.5ii Sludge Regression - 3/3/04b 


\section{Batch 11.25 Sludge Regression - 1/22/04}

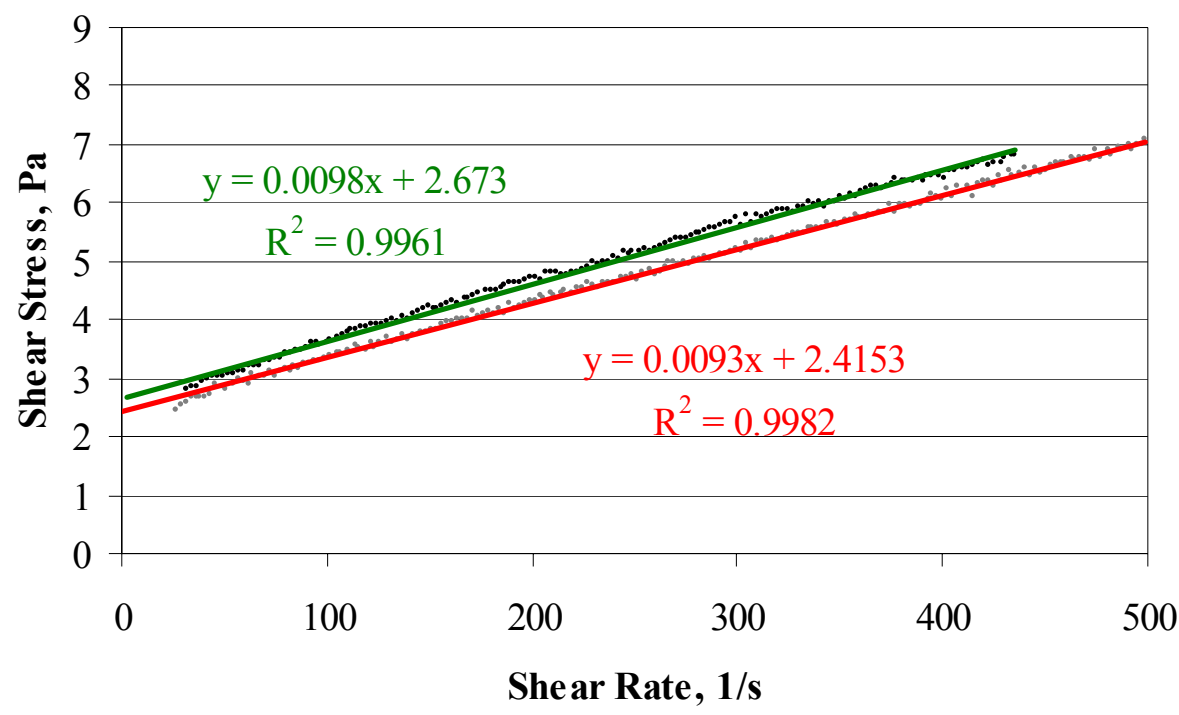

\begin{tabular}{lll}
$\cdot 11.25 \mathrm{Up}-1 / 22$ & 11.25 Down-1/22 \\
- Linear (11.25 Up-1/22) & Linear (11.25 Down-1/22) \\
\hline
\end{tabular}

Figure E- 19. Batch 11.25 Sludge Regression - 1/22/04

Batch 11.25 Sludge Regression - 1/26/04a

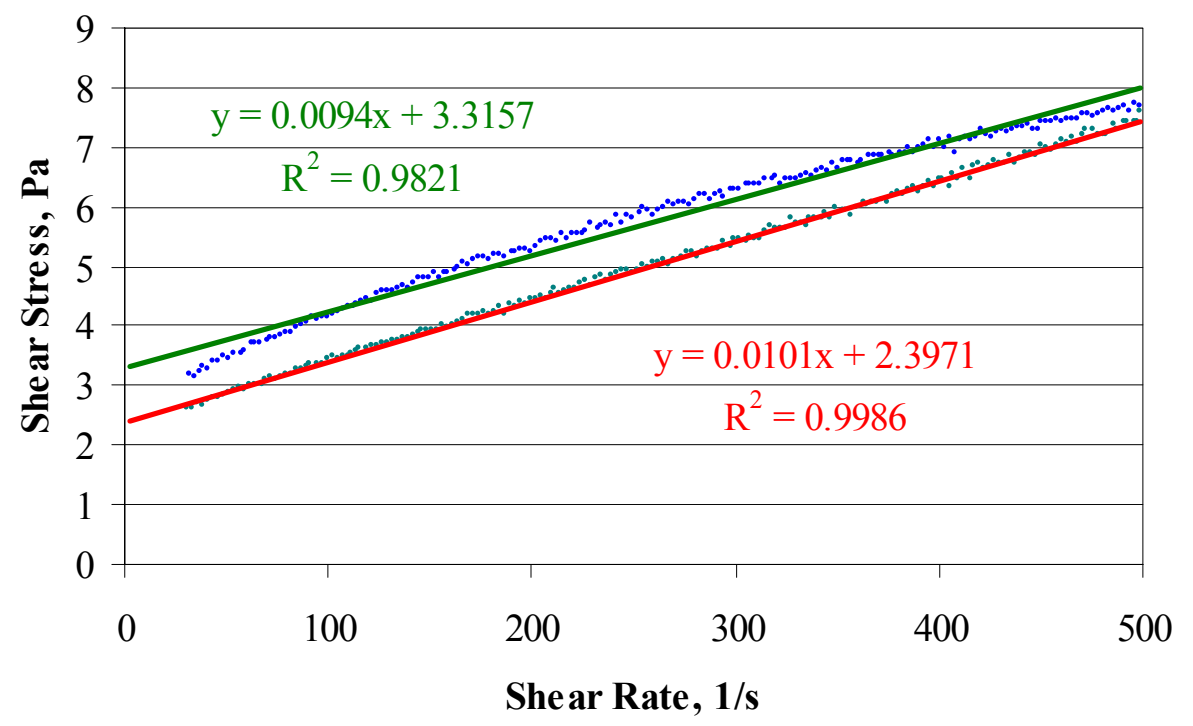

\begin{tabular}{|c|c|}
\hline - $\quad 11.25 \mathrm{Up}-1 / 26 \mathrm{a}$ & · 11.25 Down-1/26a \\
\hline — Linear (11.25 Up-1/26a) & — Linear (11.25 Down-1/26a) \\
\hline
\end{tabular}

Figure E- 20. Batch 11.25 Sludge Regression - 1/26/04a 
Batch 11.25 Sludge Regression - 1/26/04b

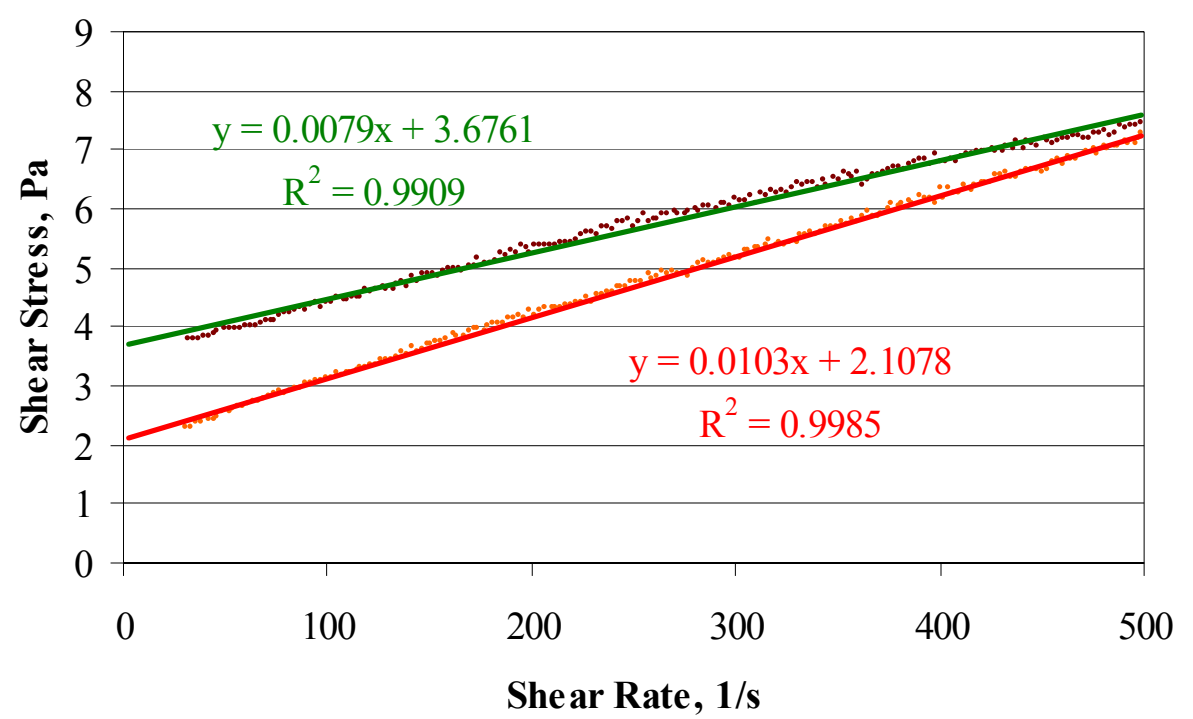

\begin{tabular}{|c|c|}
\hline · $11.25 \mathrm{Up}-1 / 26 \mathrm{~b}$ & · 11.25 Down-1/26b \\
\hline - Linear (11.25 Up-1/26b) & — Linear (11.25 Down-1/26b) \\
\hline
\end{tabular}

Figure E- 21. Batch 11.25 Sludge Regression - 1/26/04b 
Batch 11.25 Sludge Regression - 2/26/04a

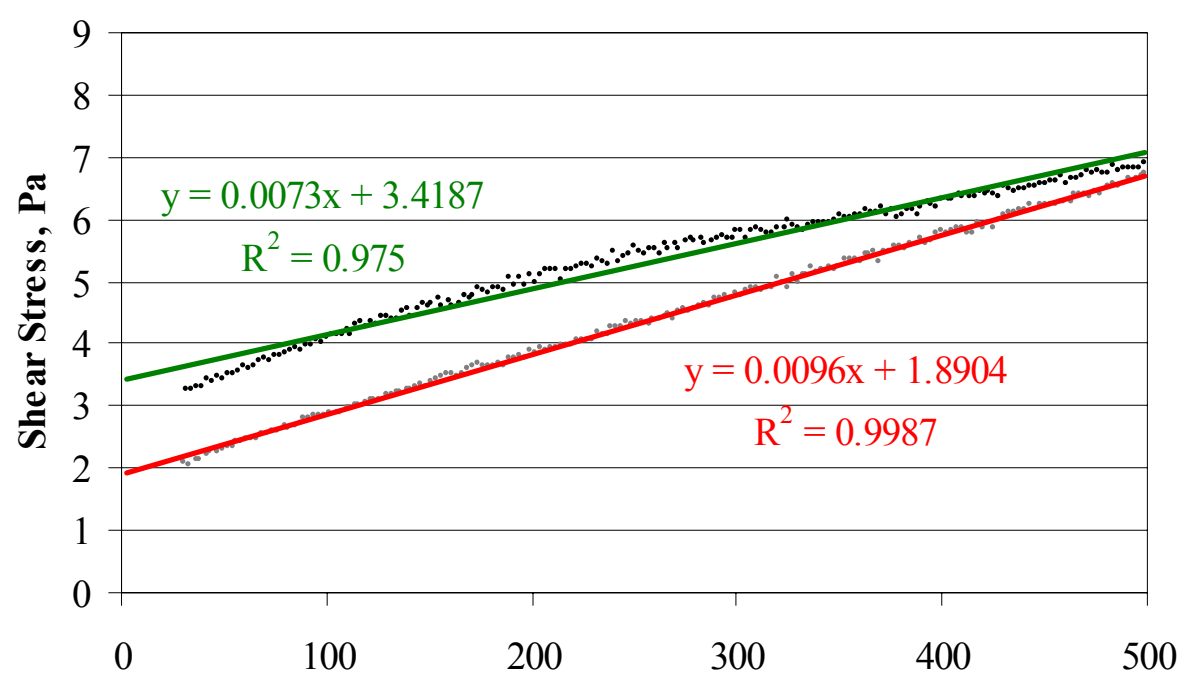

She ar Rate, 1/s

\begin{tabular}{|ll|}
\hline 11.25 Up-2/26a & 11.25 Down-2/26a \\
- Linear (11.25 Up-2/26a) & Linear (11.25 Down-2/26a) \\
\hline
\end{tabular}

Figure E- 22. Batch 11.25 Sludge Regression - 2/26/04a

Batch 11.25 Sludge Regression - 2/26/04b

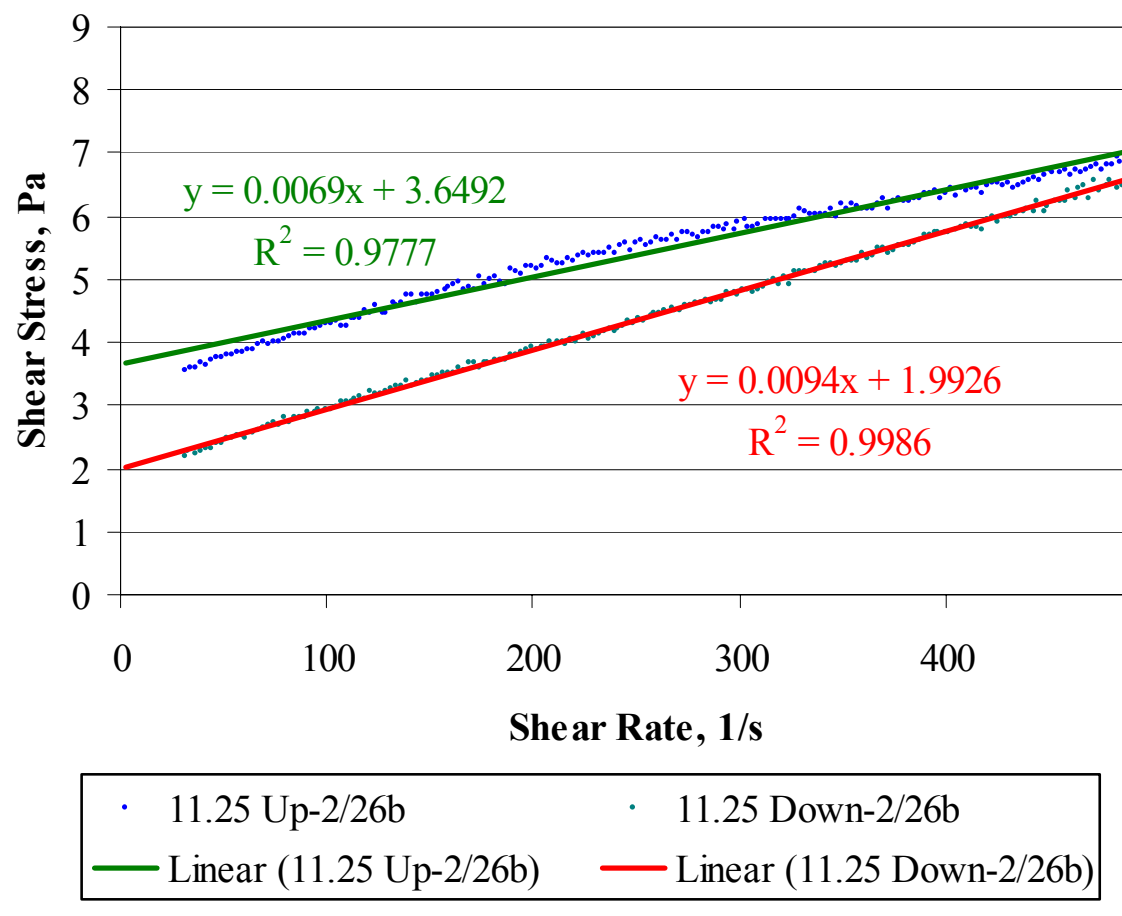

Figure E- 23. Batch 11.25 Sludge Regression - 2/26/04b 
Batch 15 Sludge Regression - 1/22/04

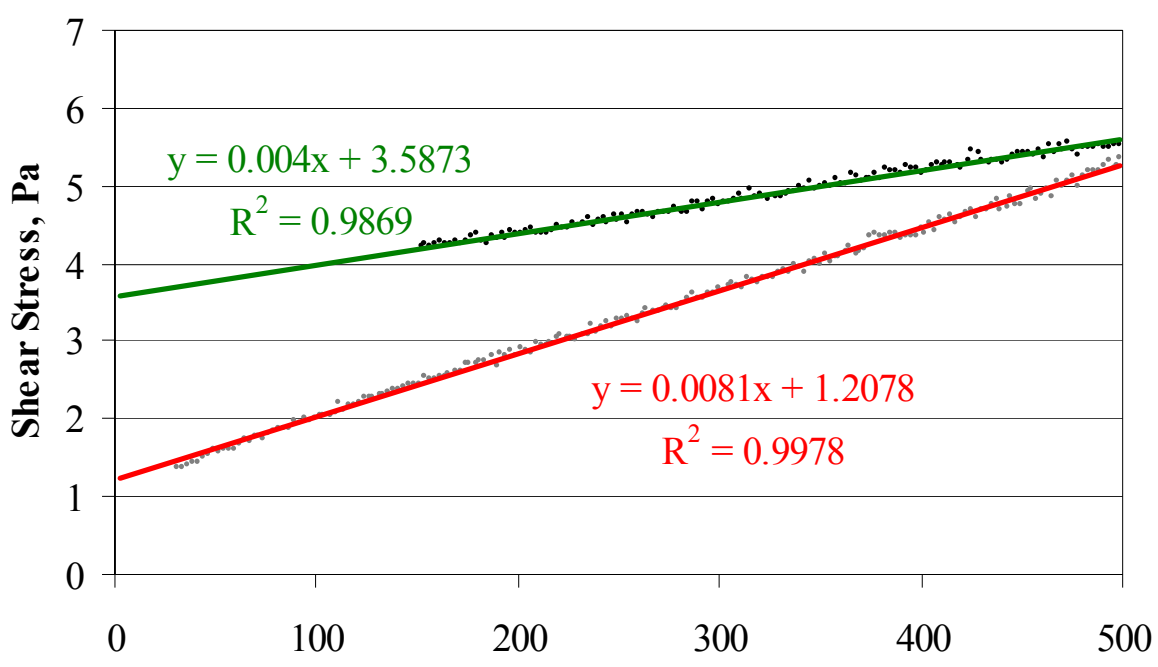

She ar Rate, 1/s

\begin{tabular}{|ll|}
\hline 15 Up-1/22 & 15 Down-1/22 \\
- Linear (15 Up-1/22) & - Linear (15 Down-1/22) \\
\hline
\end{tabular}

Figure E- 24. Batch 15 Sludge Regression - 1/22/04

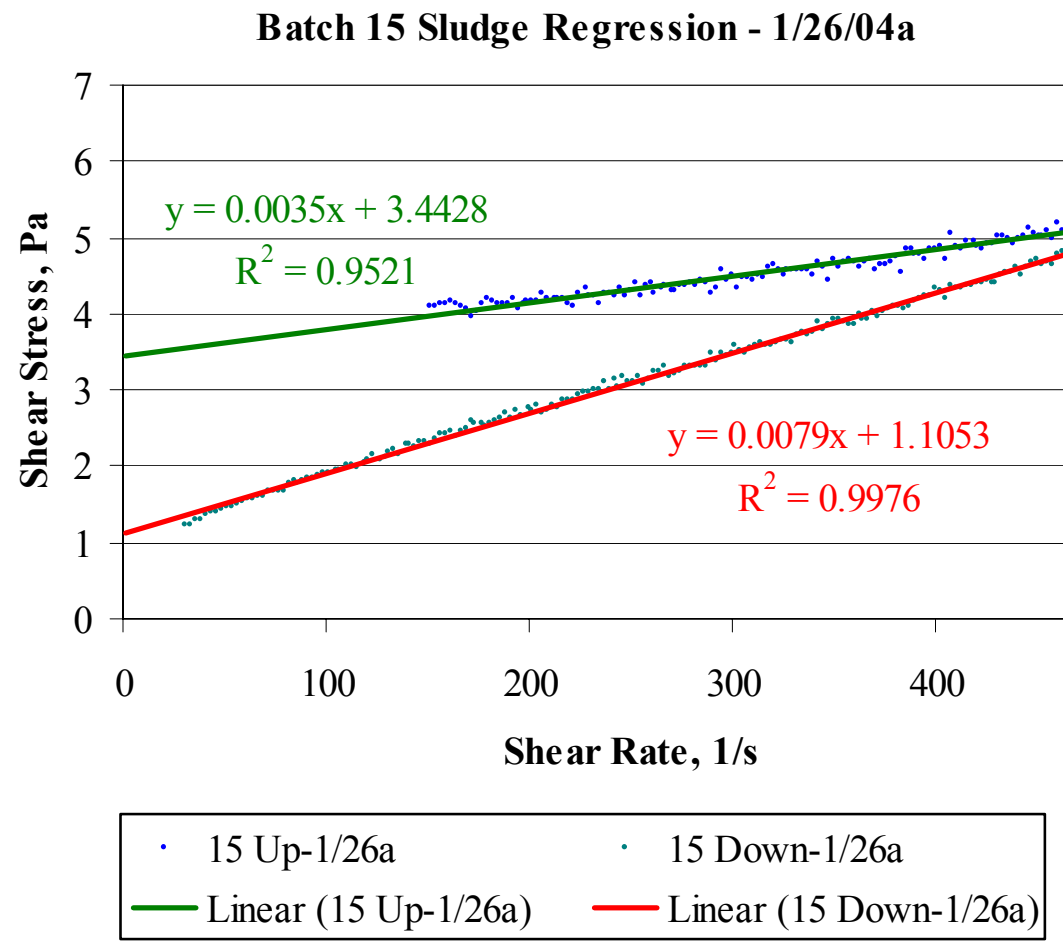

Figure E- 25. Batch 15 Sludge Regression - 1/26/04a 
Batch 15 Sludge Regression - 1/26/04b

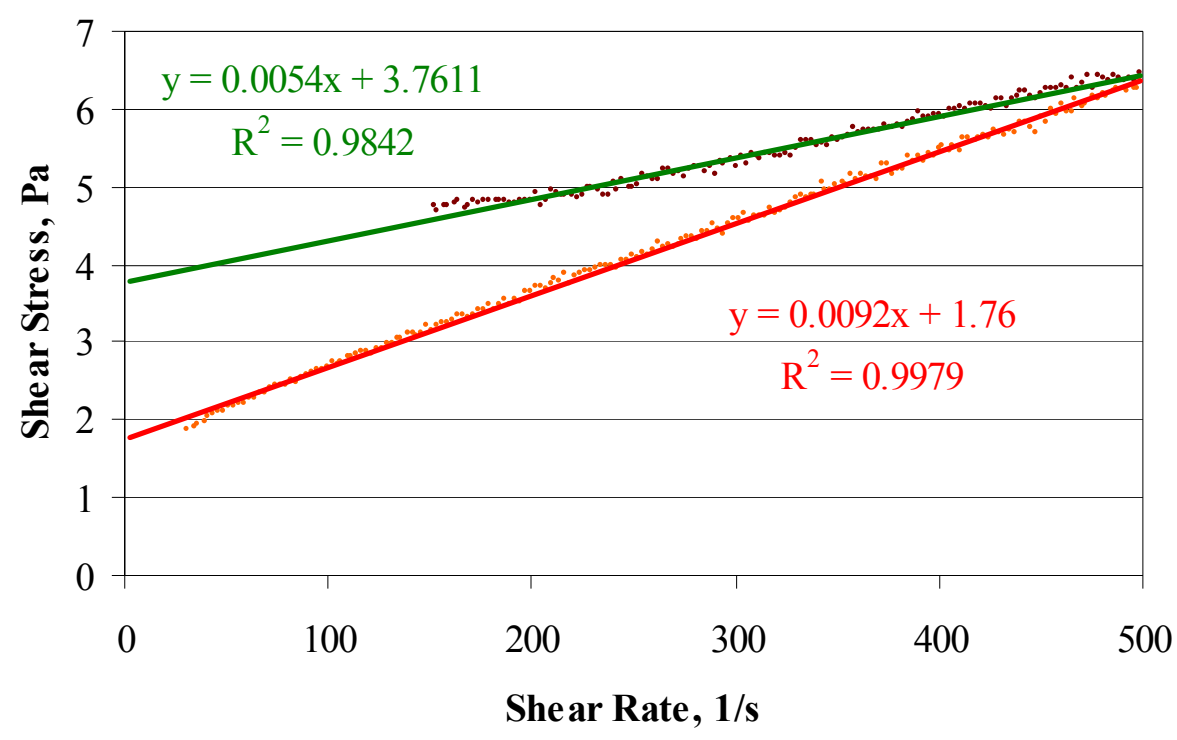

\begin{tabular}{|ll|}
\hline 15 Up-1/26b & 15 Down-1/26b \\
- Linear (15 Up-1/26b) & Linear (15 Down-1/26b) \\
\hline
\end{tabular}

Figure E- 26. Batch 15 Sludge Regression - 1/26/04b 
Batch 15 Sludge Regression - 3/1/04a

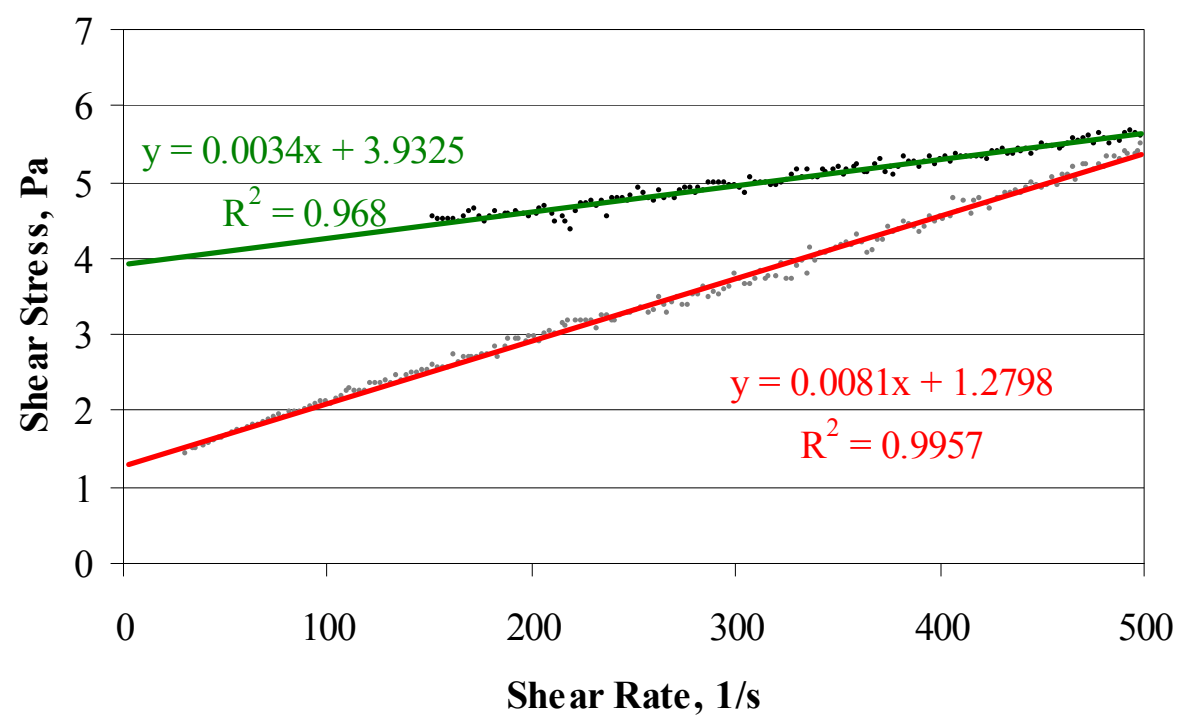

\begin{tabular}{|ll|}
\hline $\begin{array}{l}15 \mathrm{Up}-3 / 1 \mathrm{a} \\
\text { Linear (15 Up-3/1a) }\end{array}$ & 15 Down-3/1a \\
\hline & Linear (15 Down-3/1a) \\
\hline
\end{tabular}

Figure E- 27. Batch 15 Sludge Regression - 3/1/04a

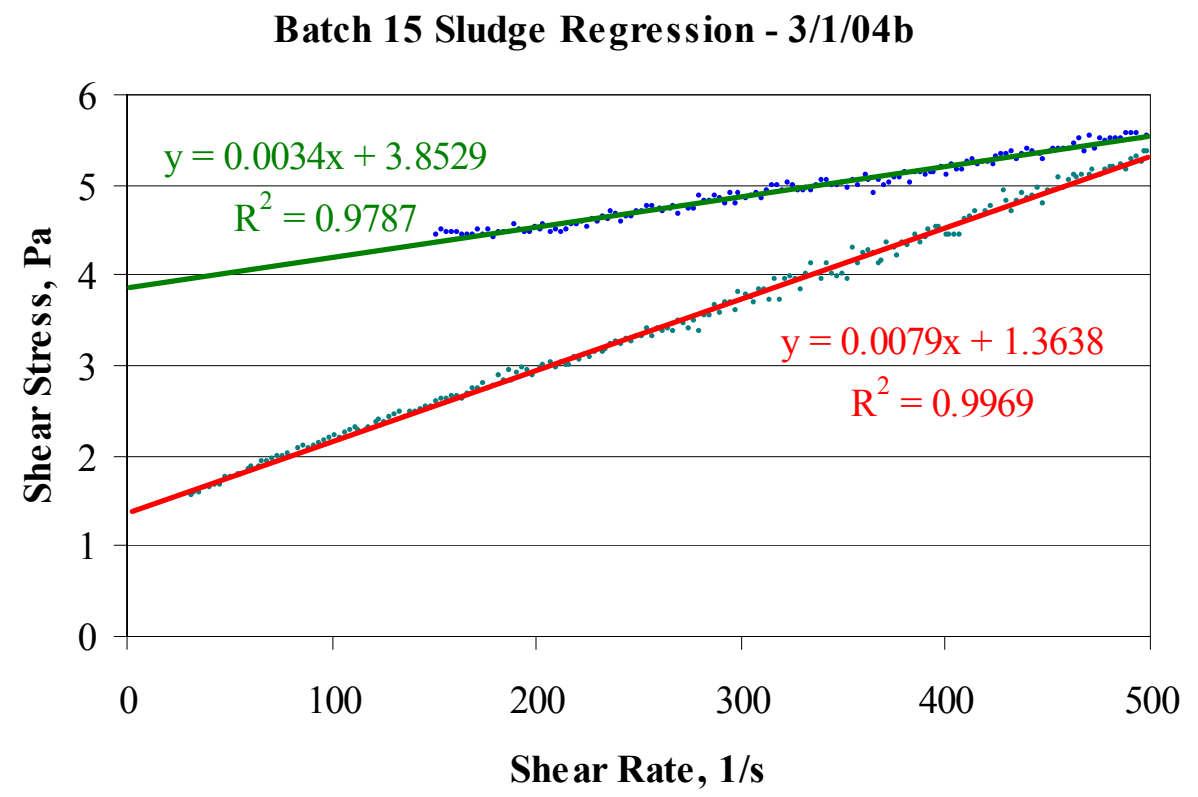

\begin{tabular}{|cc|}
\hline $\begin{array}{c}15 \mathrm{Up}-3 / 1 \mathrm{~b} \\
\text { Linear }(15 \mathrm{Up}-3 / 1 \mathrm{~b})\end{array}$ & 15 Down-3/1b \\
\hline & Linear (15 Down-3/1b) \\
\hline
\end{tabular}

Figure E- 28. Batch 15 Sludge Regression - 3/1/04b 
WSRC-TR-2004-00206

Revision 0

\section{APPENDIX F. SRAT PRODUCT RHEOGRAMS}


Key:

Black/gray = initial up/down ramp flow curves

Blue/Teal = replicate up/down ramp flow curves

Batch 0 SRAT Product

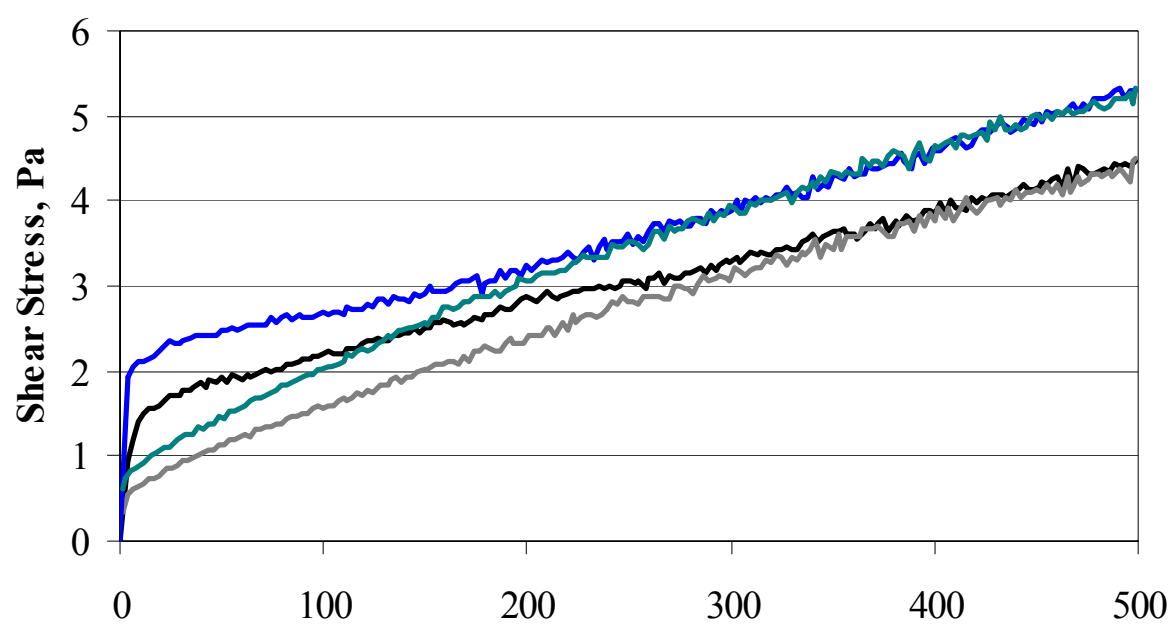

She ar Rate, 1/s

- 0 Up-1 -0 Down-1 $-0 \mathrm{Up}-2-0$ Down-2

Figure F- 1. Batch 0 SRAT Product Rheology Data

Batch 3.75-1 SRAT Product

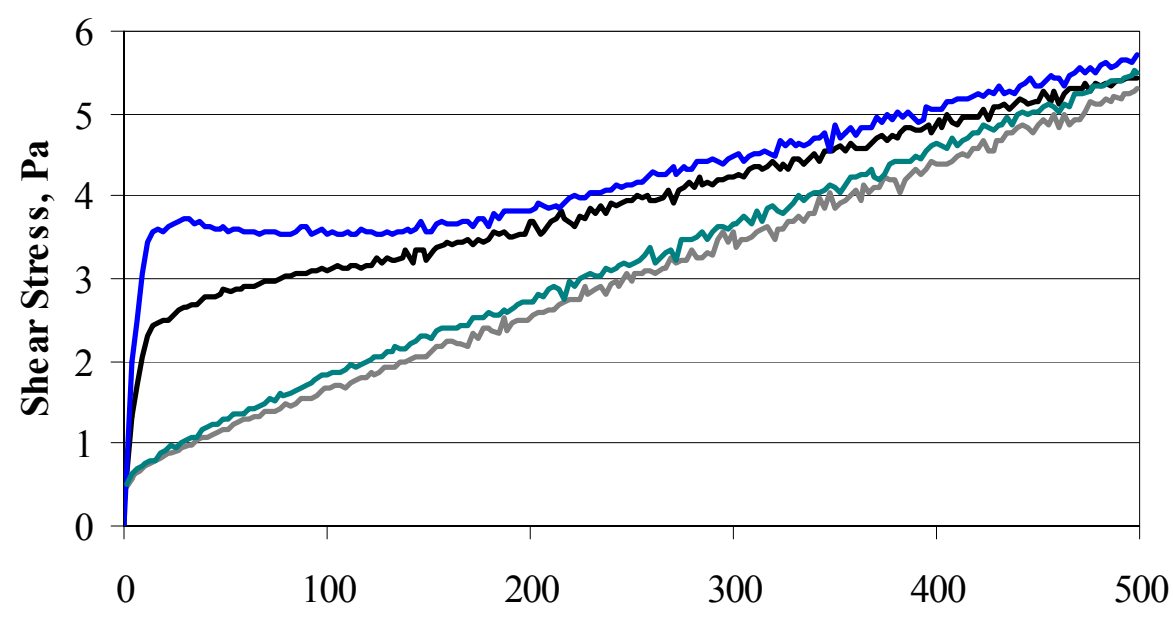

Shear Rate, 1/s

\section{$3.75 \mathrm{Up}-1-3.75$ Down-1 $-3.75 \mathrm{Up}-2-3.75$ Down-2}

Figure F- 2. Batch 3.75-1 SRAT Product Rheology Data 
Batch 3.75-2 SRAT Product

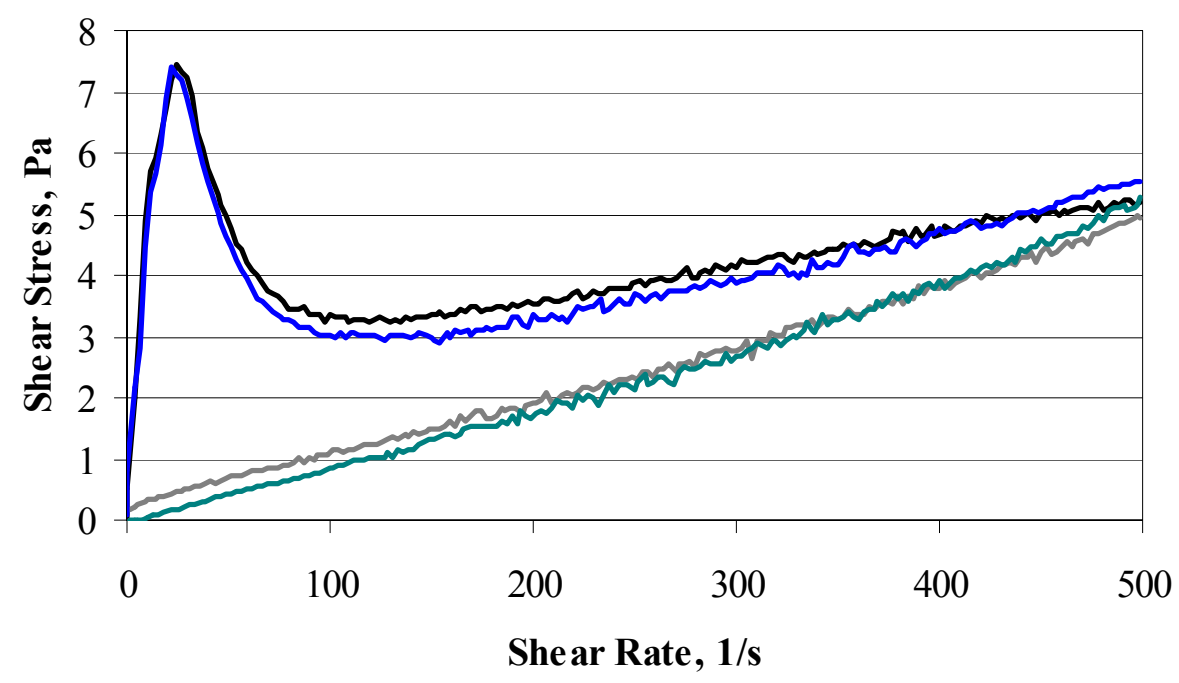

\section{$3.75 \mathrm{Up}-1-3.75$ Down-1 $-3.75 \mathrm{Up}-2-3.75$ Down-2}

Figure F- 3. Batch 3.75-2 SRAT Product Rheology Data

Batch 7.5i SRAT Product

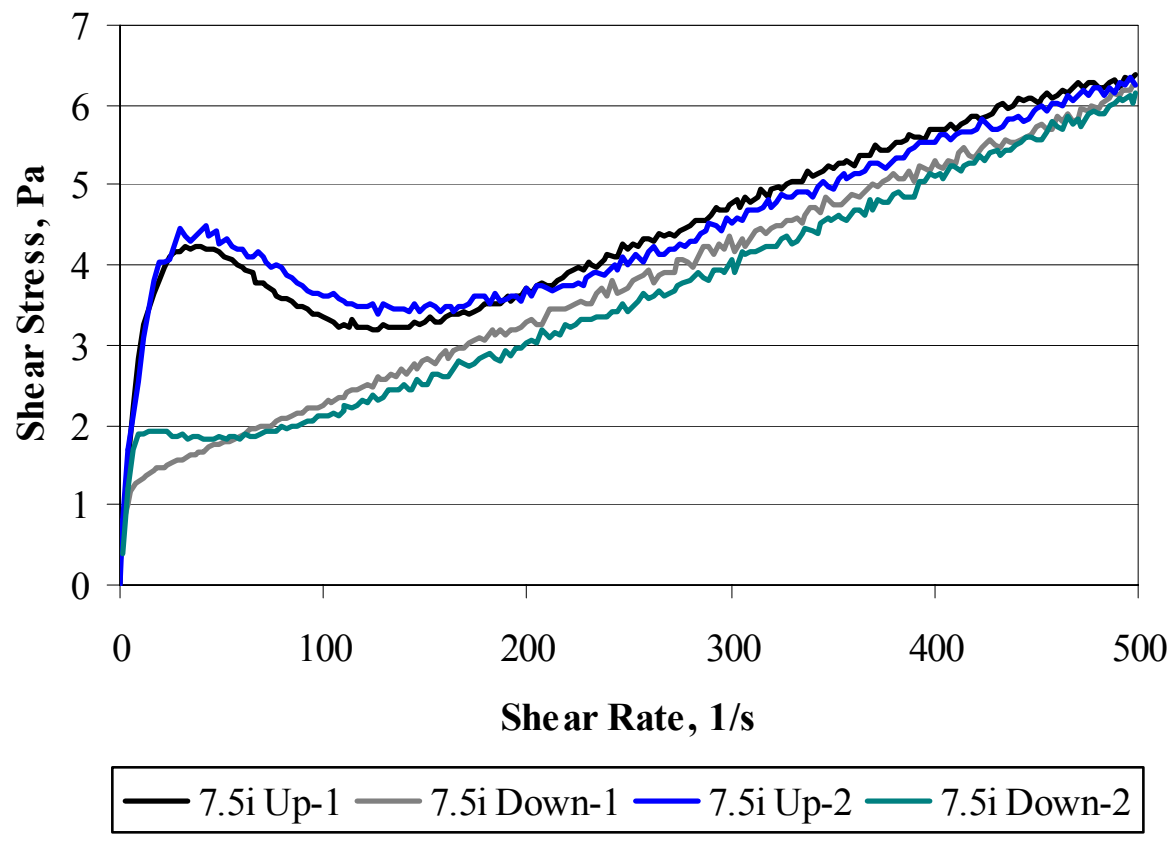

Figure F- 4. Batch 7.5i SRAT Product Rheology Data 
Batch 7.5ii SRAT Product

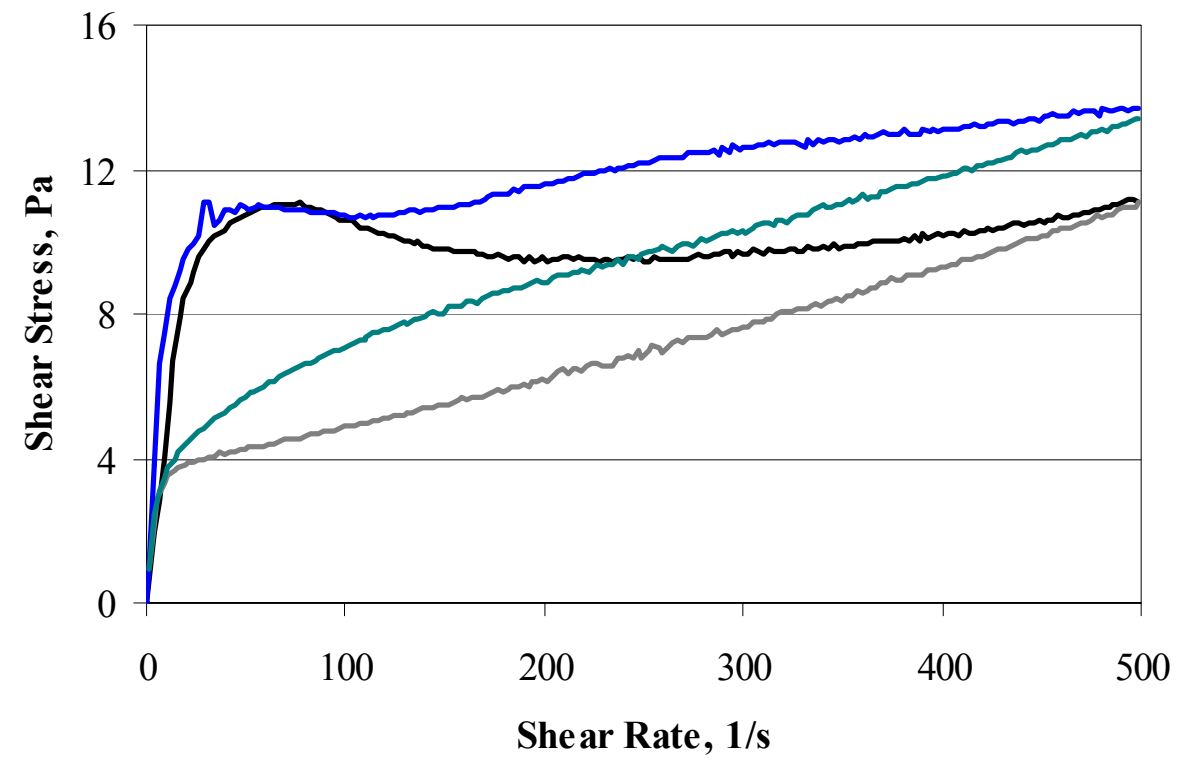

7.5ii Up-1 - 7.5ii Down-1 - 7.5ii Up-2 - 7.5ii Down-2

Figure F- 5. Batch 7.5ii SRAT Product Rheology Data

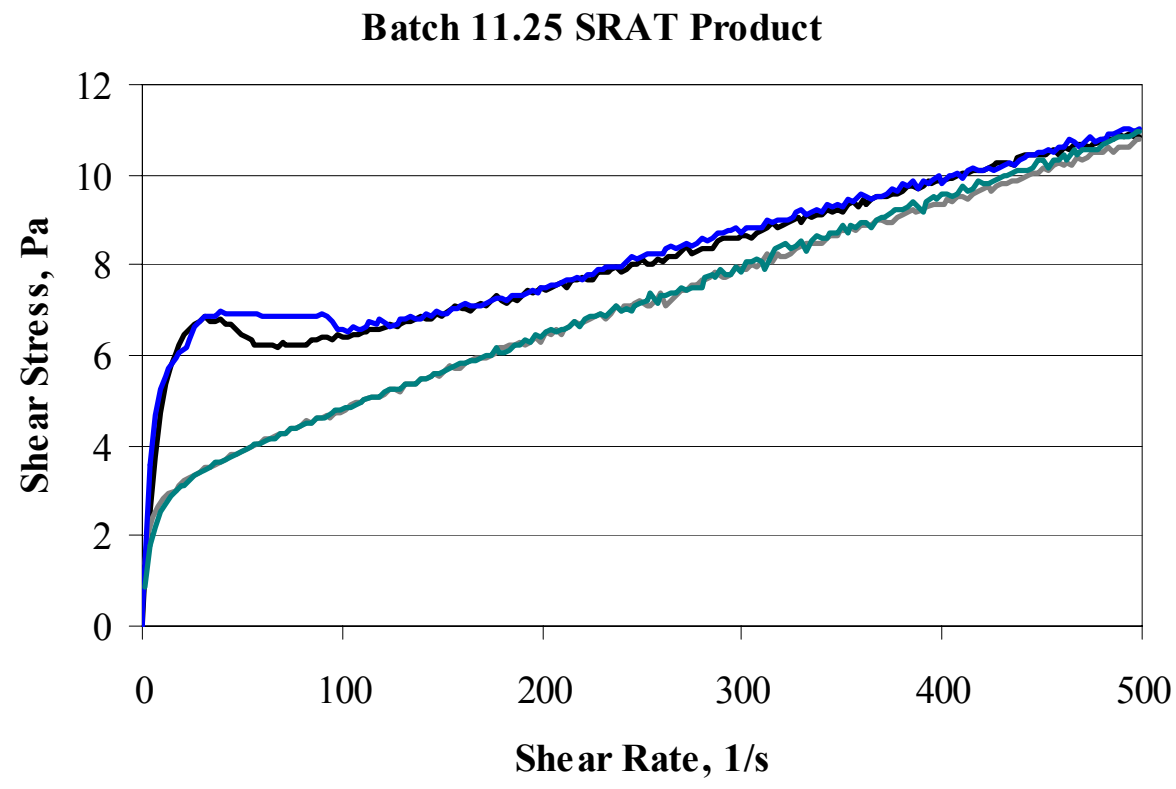

$11.25 \mathrm{Up}-1-11.25$ Down-1 $-11.25 \mathrm{Up}-2-11.25$ Down-2

Figure F- 6. Batch 11.25 SRAT Product Rheology Data 


\section{Batch 15 SRAT Product}

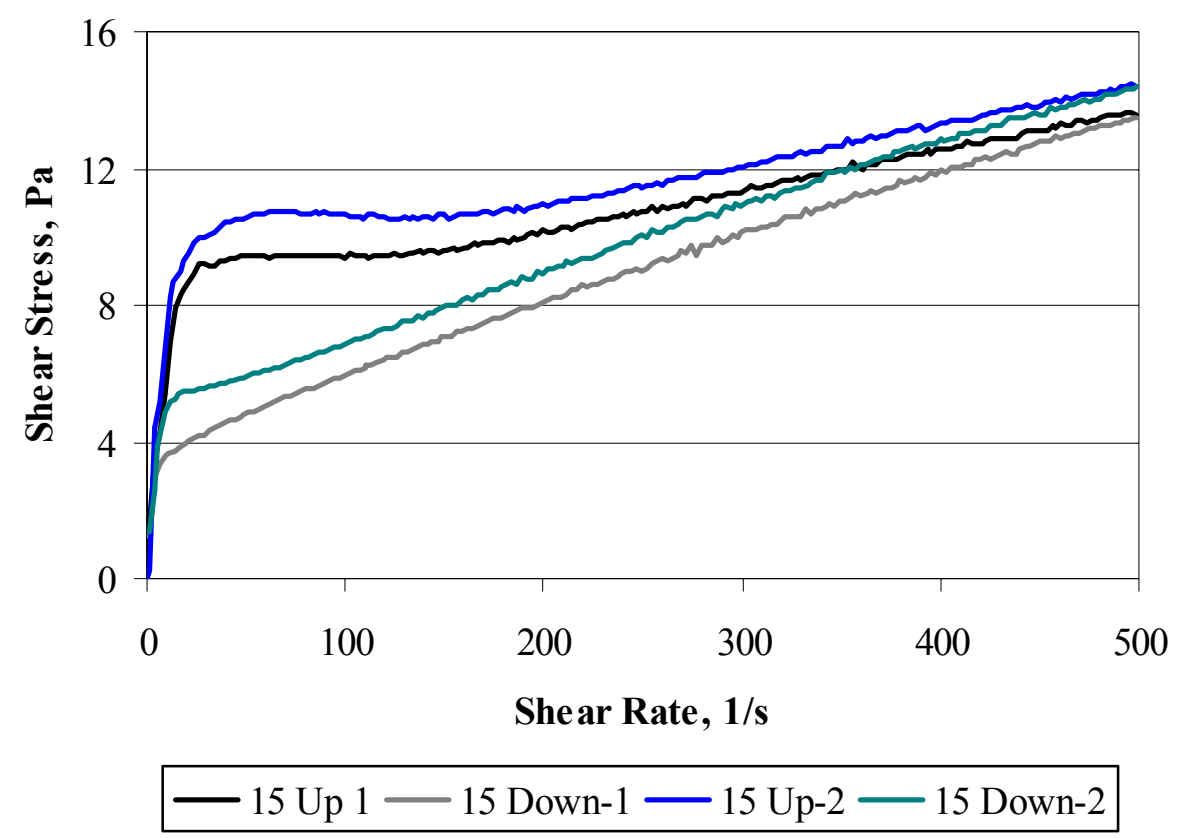

Figure F- 7. Batch 15 SRAT Product Rheology Data 
WSRC-TR-2004-00206

Revision 0

This page intentionally left blank. 
WSRC-TR-2004-00206

Revision 0

APPENDIX G. SRAT PRODUCT REGRESSION ANALYSES 
Key:

Green = up curve regressions

Red = down curve regressions

Batch 0 SRAT Product - Initial Results

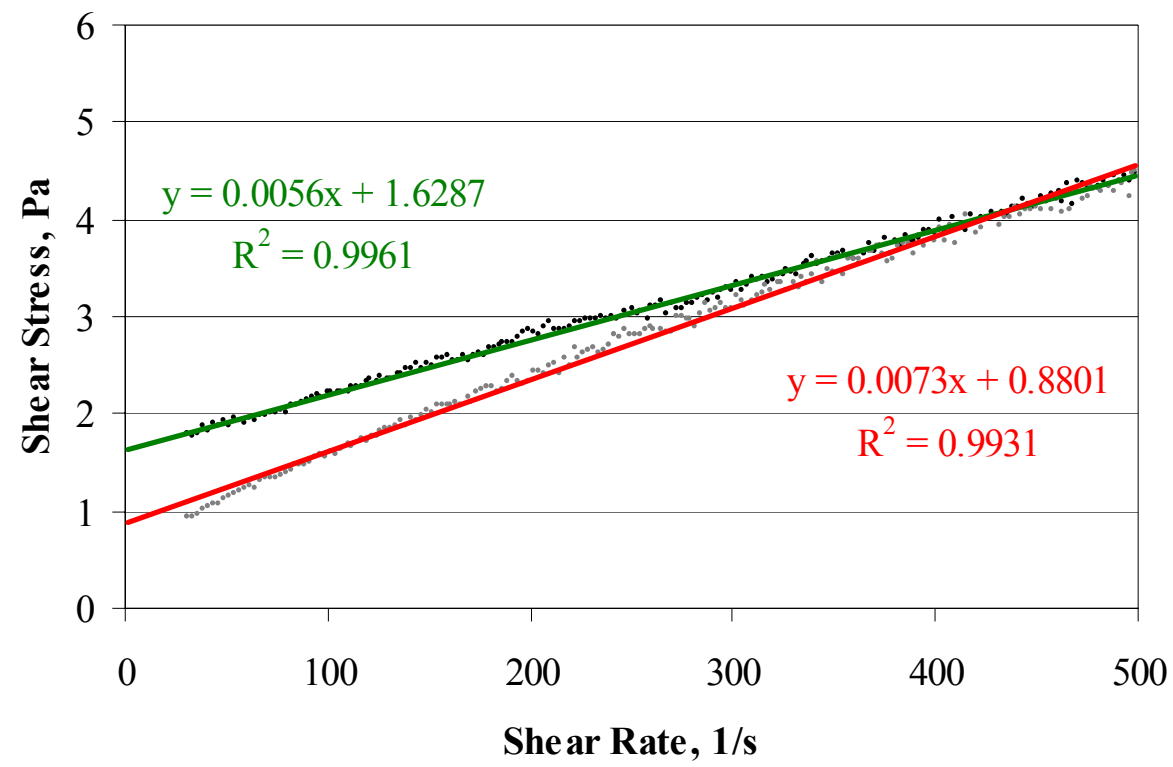
- $0 \mathrm{Up}-1$
0 Down-1
Linear (0 Up-1)
Linear (0 Down-1)

Figure G- 1. Batch 0 SRAT Product Regression - Initial

Batch 0 SRAT Product - Replicate Results

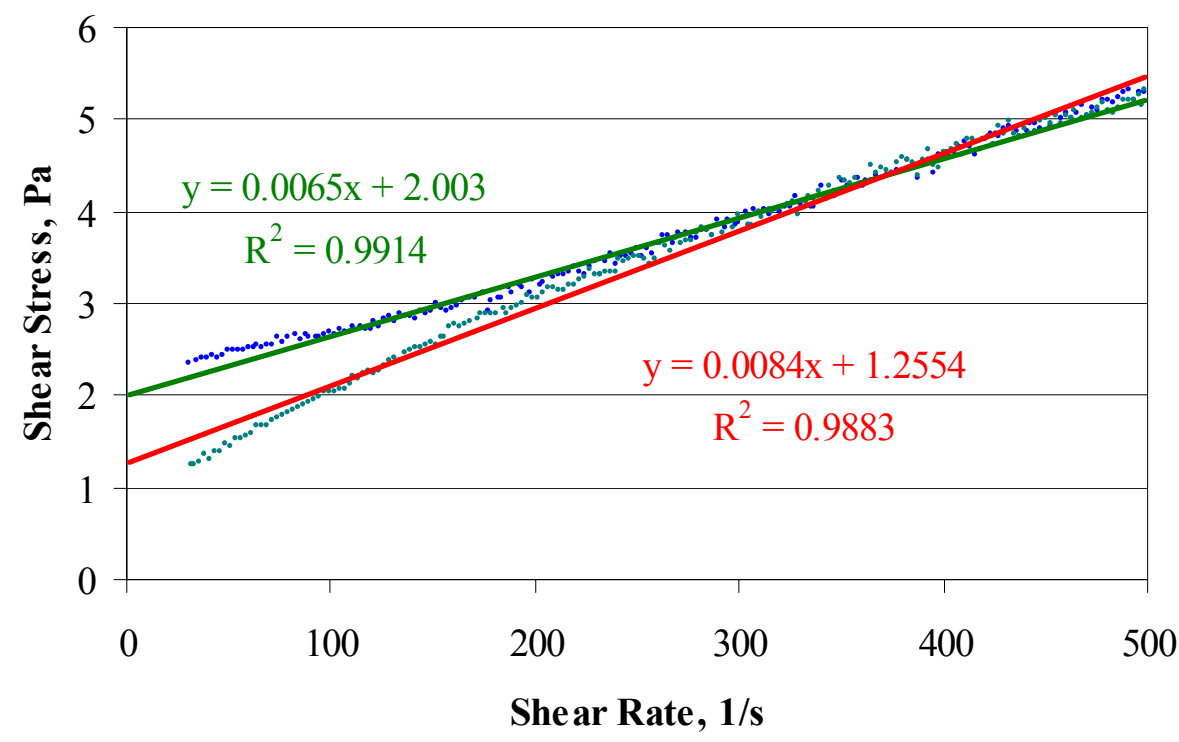

. 0 Up-2 $\quad 0$ Down-2 — Linear (0 Up-2) - Linear (0 Down-2)

Figure G- 2. Batch 0 SRAT Product Regression - Replicate 
Batch 3.75-1 SRAT Product - Initial Results

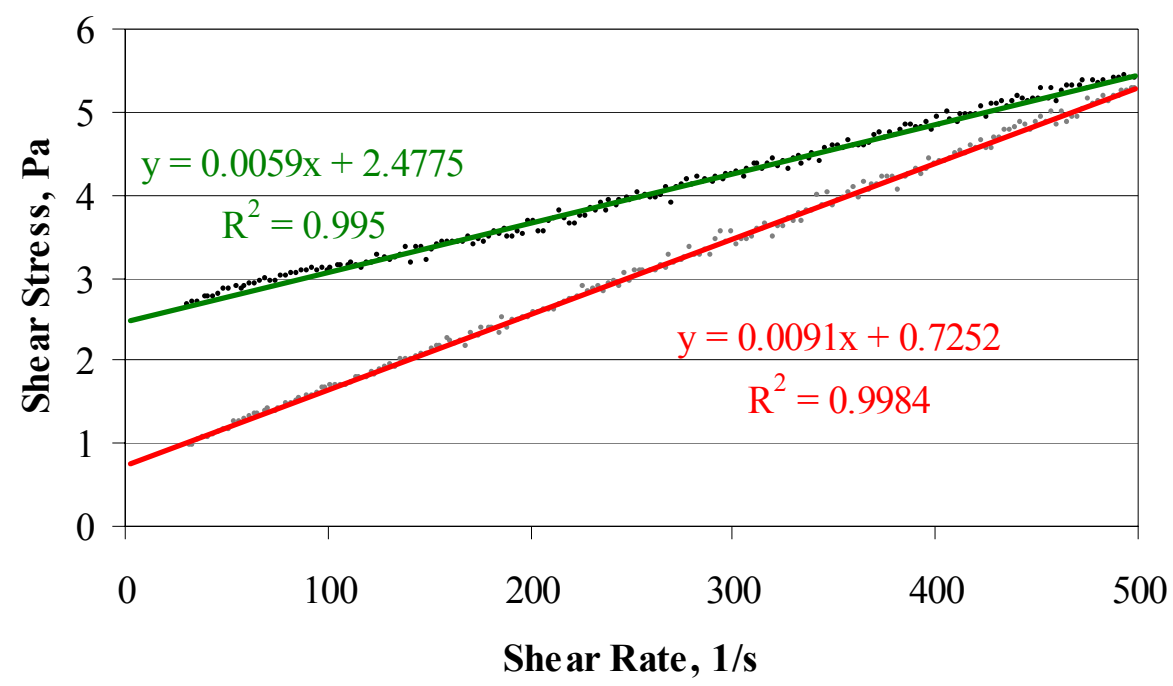

\begin{tabular}{|c|c|}
\hline 3.75-1 Up-1 & · 3.75-1 Down-1 \\
\hline — Linear (3.75-1 Up-1) & — Linear (3.75-1 Down-1) \\
\hline
\end{tabular}

Figure G- 3. Batch 3.75 SRAT 1 Product Regression - Initial

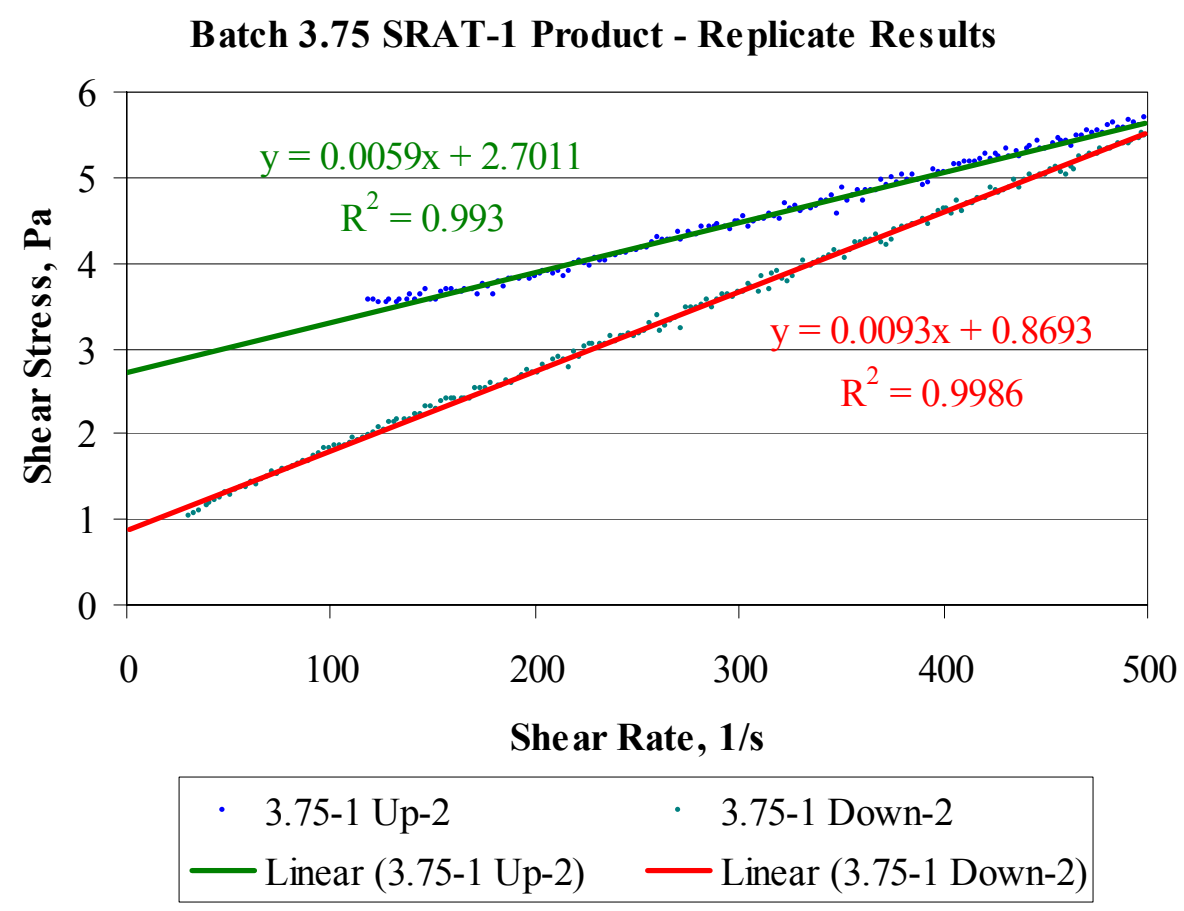

Figure G- 4. Batch 3.75 SRAT 1 Product Regression - Replicate 
Batch 3.75-2 SRAT Product - Initial Results

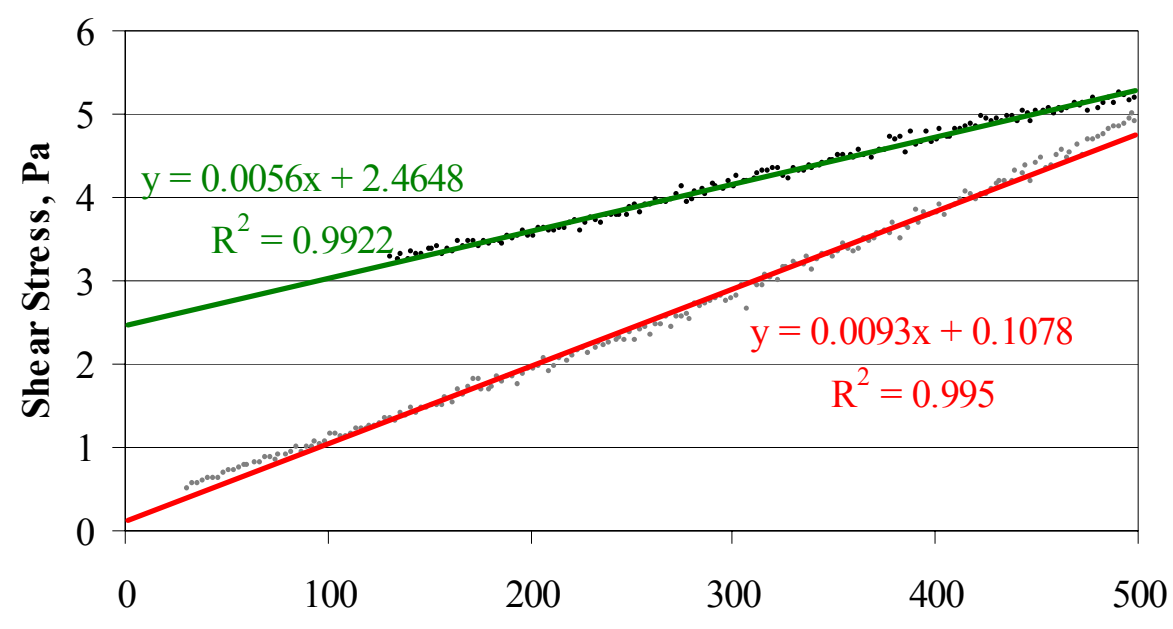

She ar Rate, 1/s

\begin{tabular}{|c|c|}
\hline · $\quad 3.75-2 \mathrm{Up}-1$ & · 3.75-2 Down-1 \\
\hline — Linear (3.75-2 Up-1) & - Linear (3.75-2 Down-1) \\
\hline
\end{tabular}

Figure G- 5. Batch 3.75 SRAT 2 Product Regression - Initial

Batch 3.75-2 SRAT Product - Replicate Results

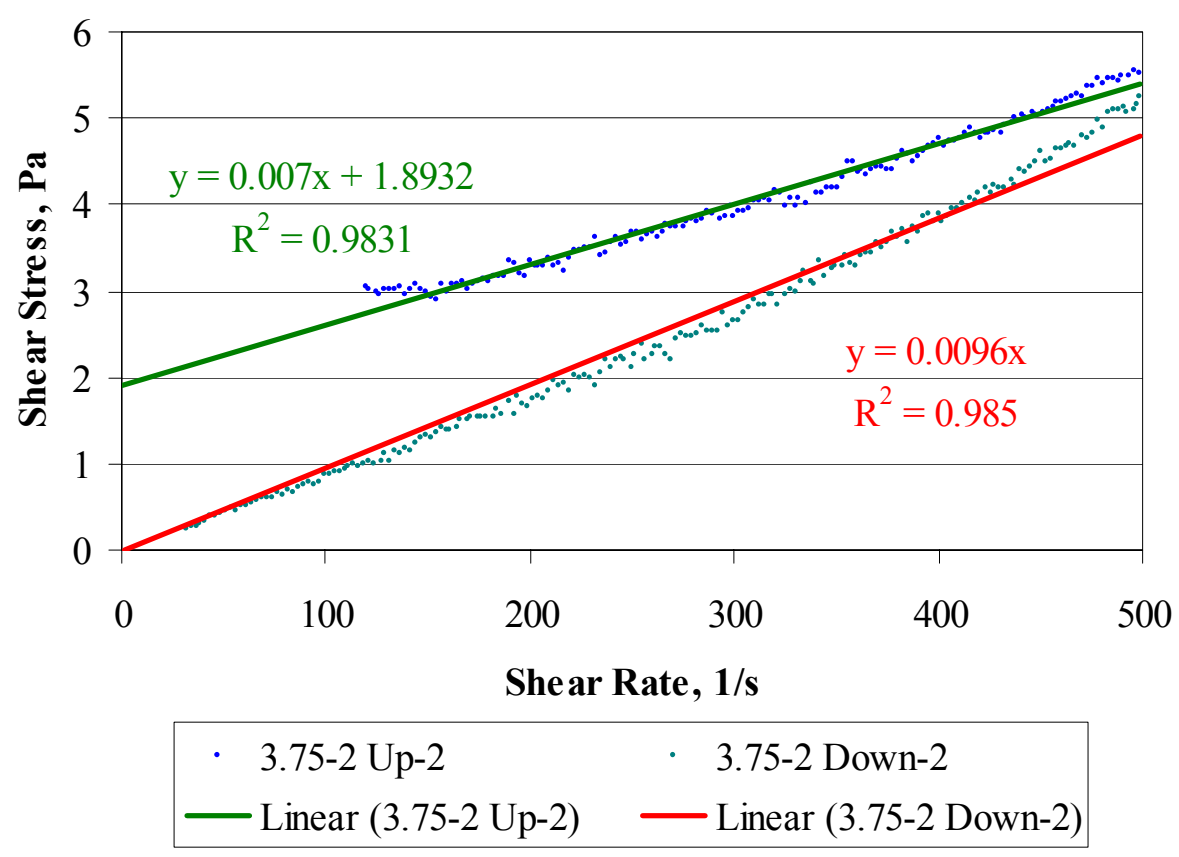

Figure G- 6. Batch 3.75 SRAT 2 Product Regression - Replicate 


\section{Batch 7.5i SRAT Product - Initial Results}

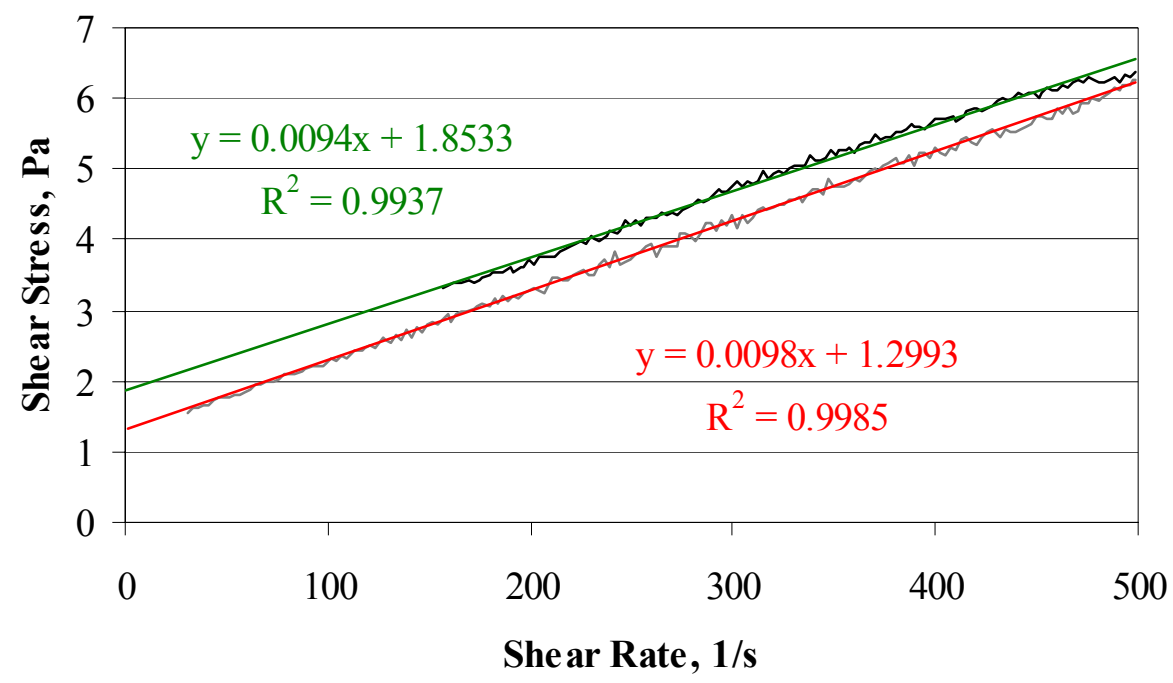

\begin{tabular}{|ll}
\hline 7.5i Up-1 & - 7.5i Down-1 \\
- Linear (7.5i Up-1) & - Linear (7.5i Down-1) \\
\hline
\end{tabular}

Figure G- 7. Batch 7.5i SRAT Product Regression - Initial

Batch 7.5i SRAT Product - Replicate Results

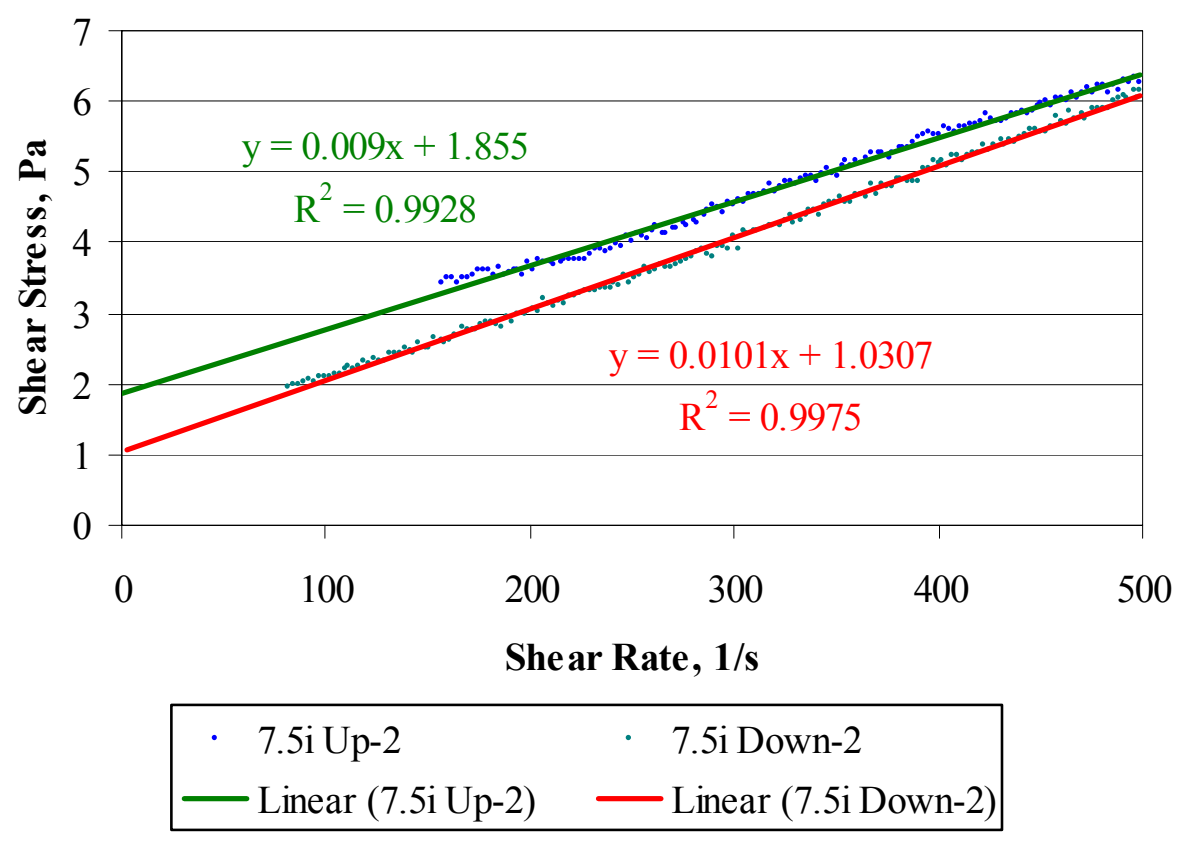

Figure G- 8. Batch 7.5i SRAT Product Regression - Replicate 


\section{Batch 7.5ii SRAT Product - Initial Results}

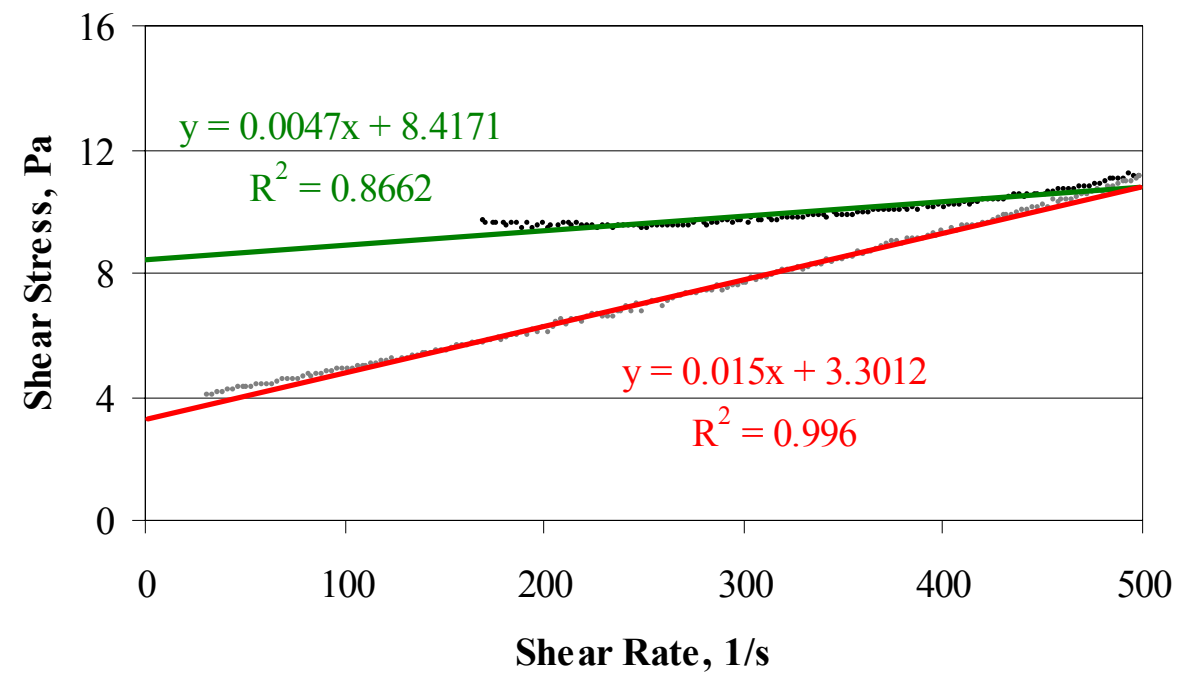

\begin{tabular}{cc|} 
7.5ii Up-1 & 7.5ii Down-1 \\
- Linear (7.5ii Up-1) & $\quad$ Linear (7.5ii Down-1) \\
\hline
\end{tabular}

Figure G- 9. Batch 7.5ii SRAT Product Regression - Initial

Batch 7.5ii SRAT Product - Replicate Results

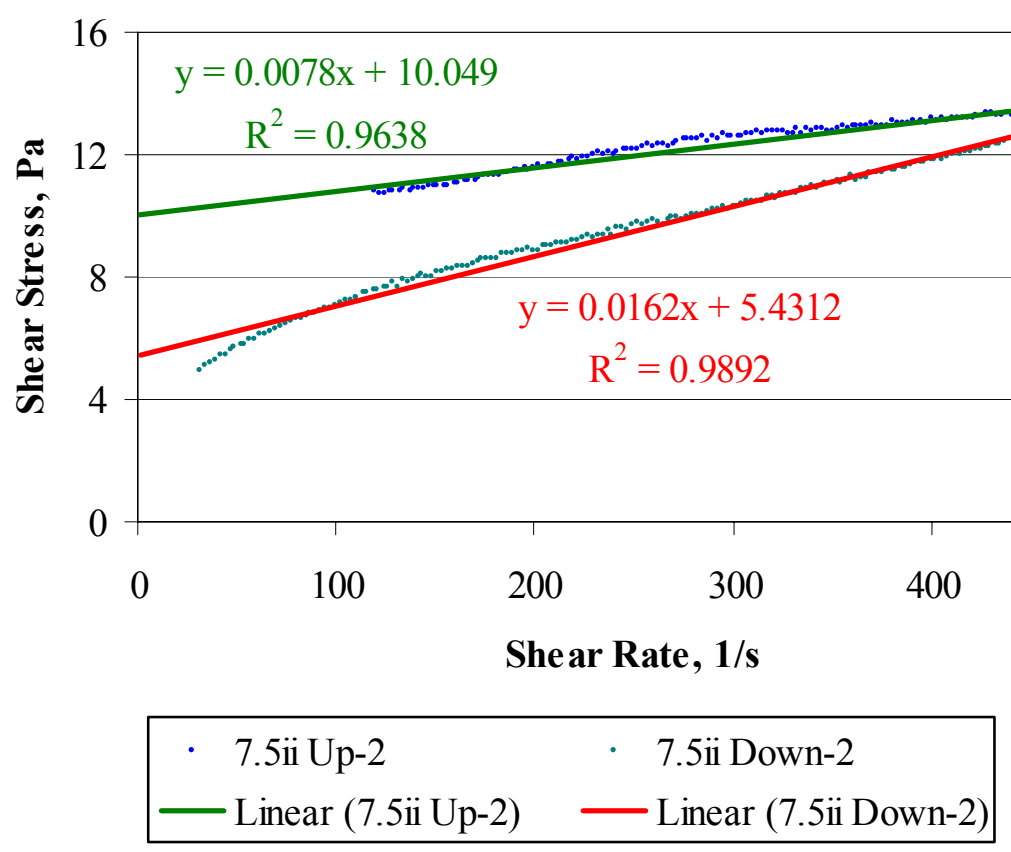

Figure G- 10. Batch 7.5ii SRAT Product Regression - Replicate 


\section{Batch 11.25 SRAT Product - Initial Results}

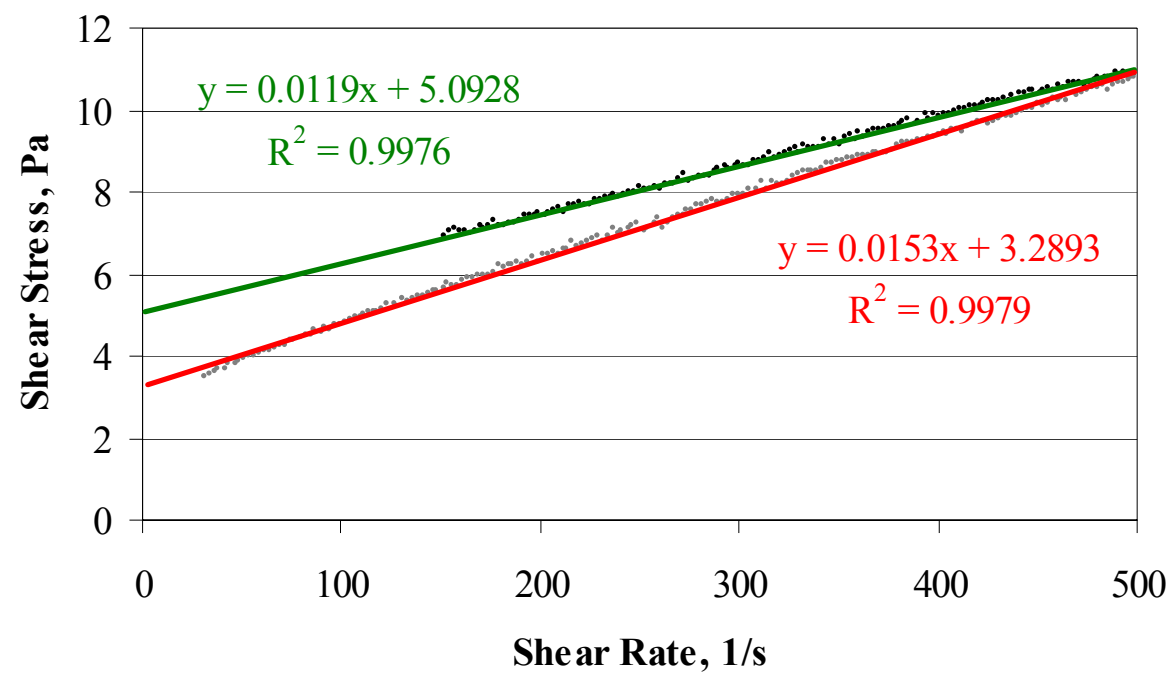

\begin{tabular}{|ll|}
\hline 11.25 Up-1 & 11.25 Down-1 \\
- Linear (11.25 Up-1) & Linear (11.25 Down-1) \\
\hline
\end{tabular}

Figure G- 11. Batch 11.25 SRAT Product Regression - Initial

Batch 11.25 SRAT Product - Replicate Results

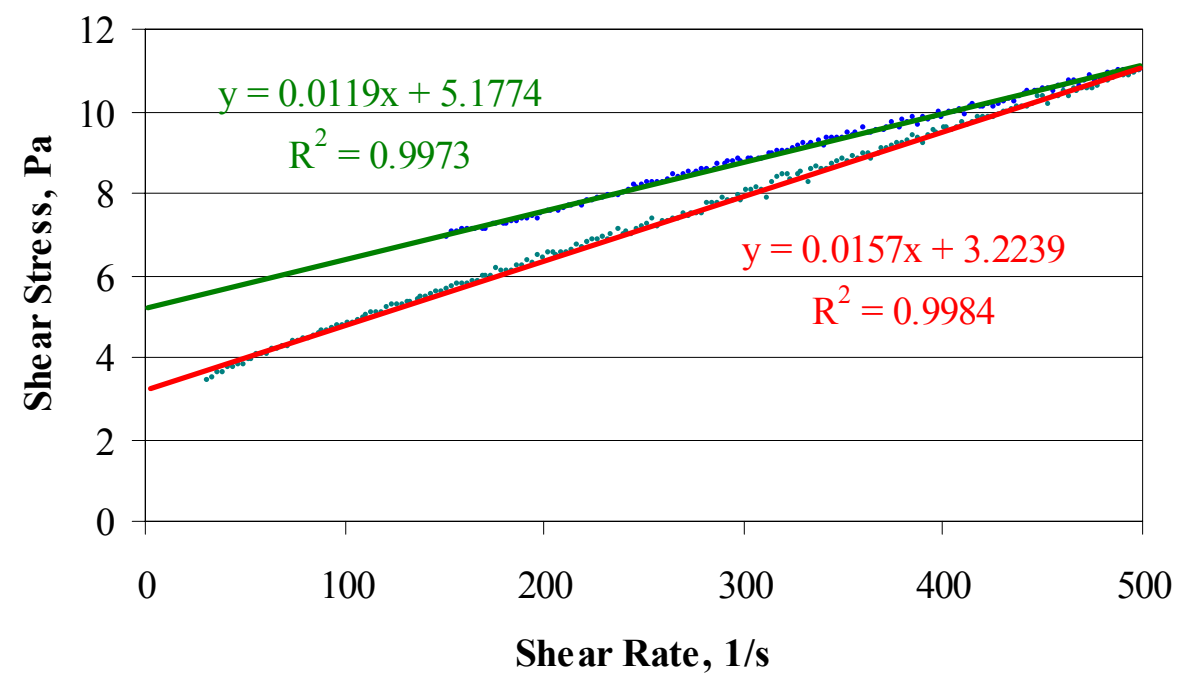

\begin{tabular}{|ll|}
\hline $11.25 \mathrm{Up}-2$ & 11.25 Down-2 \\
- Linear (11.25 Up-2) & - Linear (11.25 Down-2) \\
\hline
\end{tabular}

Figure G- 12. Batch 11.25 SRAT Product Regression - Replicate 
Batch 15 SRAT Product - Initial Results

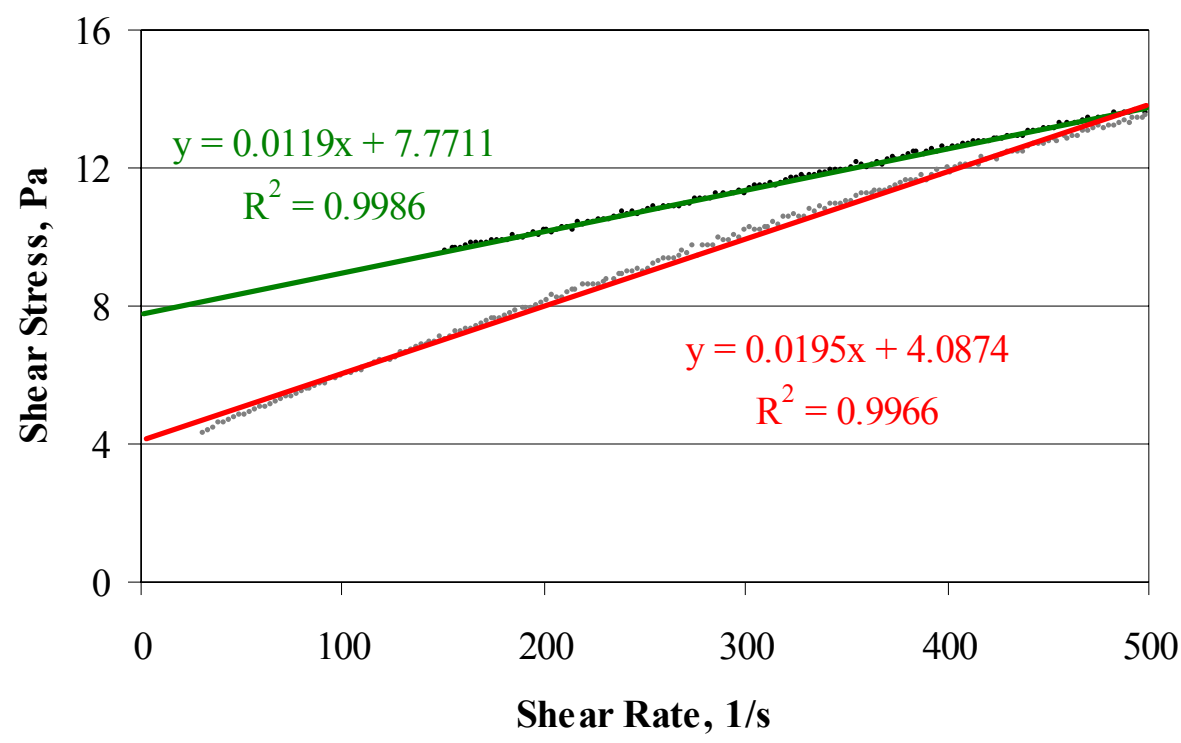

- $15 \mathrm{Up}-1$ · 15 Down-1 — Linear (15 Up-1) — Linear (15 Down-1)

Figure G- 13. Batch 15 SRAT Product Regression - Initial

Batch 15 SRAT Product - Replicate Results

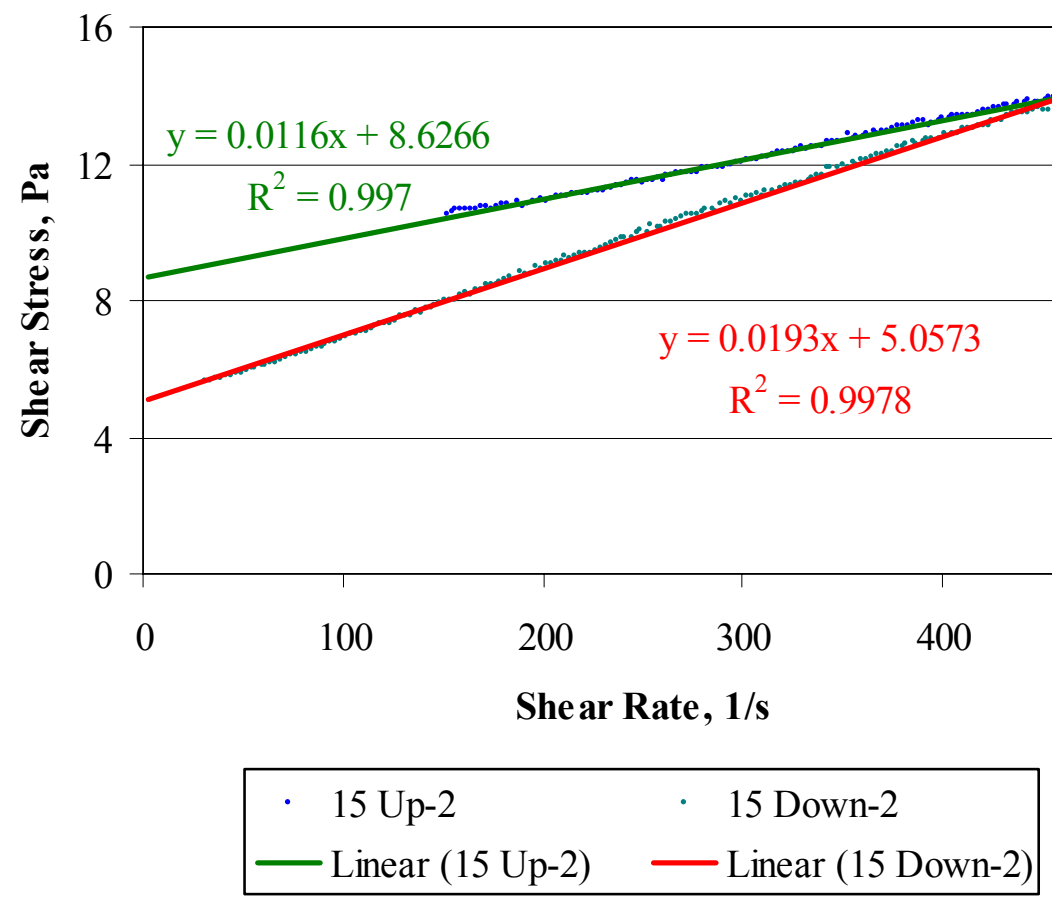

Figure G- 14. Batch 15 SRAT Product Regression - Replicate 